\title{
A réz-efflux szabályzó CueR fehérje fémkötő sajátságainak tanulmányozása modellpeptideken keresztül
}

Doktori (Ph.D) értekezés

Szunyogh Dániel Mihály

Témavezetők:

Dr. Jancsó Attila

Dr. Gyurcsik Béla

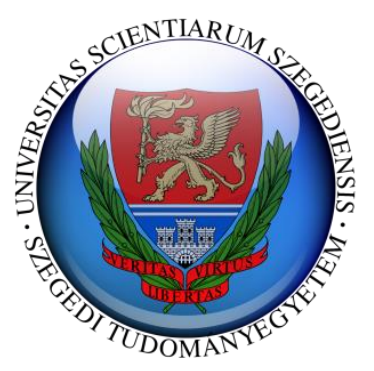

Szegedi Tudományegyetem

Természettudományi és Informatikai Kar

Kémia Doktori Iskola

Szervetlen és Analitikai Kémiai Tanszék

Szeged 



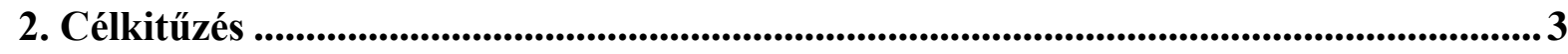

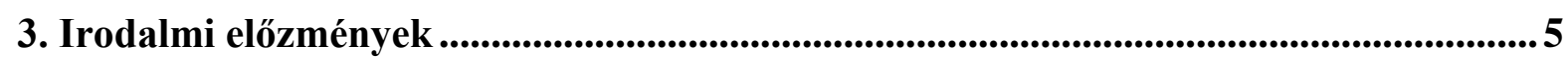

3.1. A fémion-háztartás müködése, alapvető folyamatai.................................................... 5

3.2. A bakteriális fémion-szabályzó fehérjék fajtái, funkciói............................................ 7

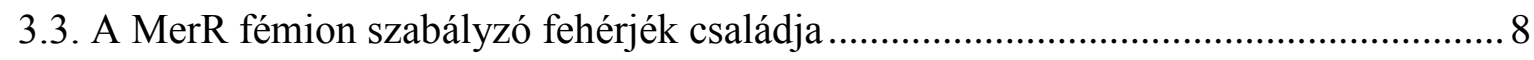

3.3.1. $\mathrm{A} \mathrm{Hg}^{2+}$-szabályozó MerR fehérje ................................................................ 9

3.3.2. $\mathrm{A} \mathrm{Zn}^{2+}$ - és $\mathrm{Cd}^{2+}$-érzékeny $\mathrm{ZntR}$ szabályzó fehérje ........................................... 10

3.3.3. $\mathrm{A} \mathrm{Cu}^{+}$- és $\mathrm{Ag}^{+}$-függő CueR szabályzó fehérje ............................................... 11

3.3.4. A szabályozó fehérjék összevetése fémkötő sajátságaik alapján ......................... 14

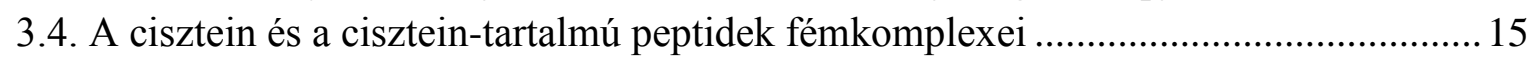

3.4.1. Cisztein és egyéb cisztein-származékok $\mathrm{d}^{10}$ fémionokkal alkotott komplexei..... 15

3.4.2. Egy ciszteint tartalmazó peptidek $\mathrm{d}^{10}$ fémionokkal alkotott komplexei ............... 17

3.4.3. Több ciszteint tartalmazó peptidek $\mathrm{d}^{10}$ fémionokkal alkotott komplexei ............. 19

4. Kísérleti és vizsgálati módszerek...................................................................................................26

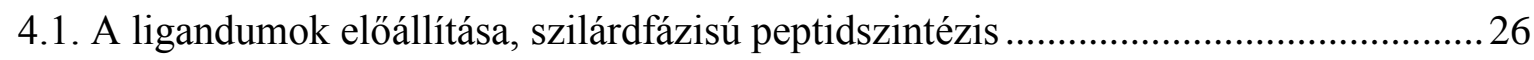

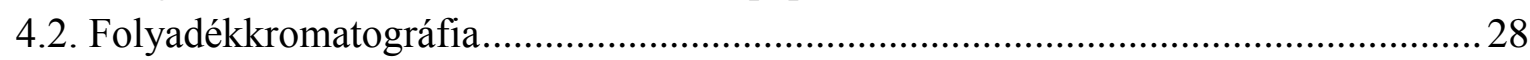

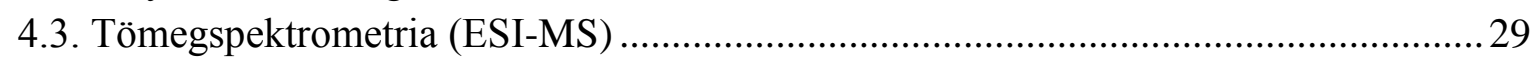

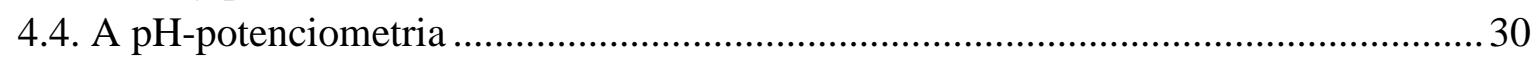

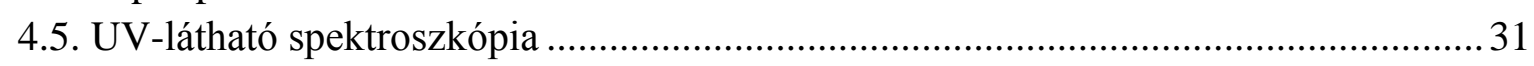

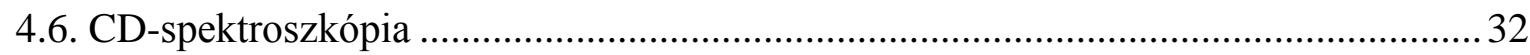

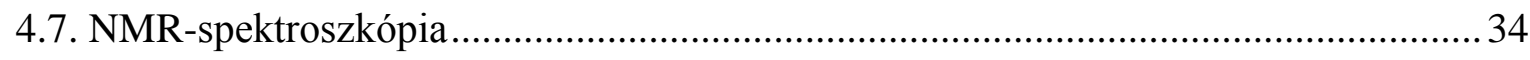

4.8. Perturbált gamma-gamma szögkorrelációs spektroszkópia (PAC) ............................. 35

5. Kísérleti eredmények és értékelésük.................................................................................38

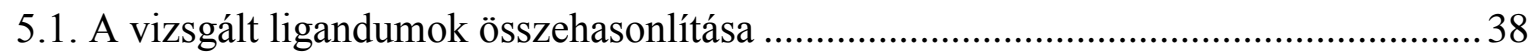

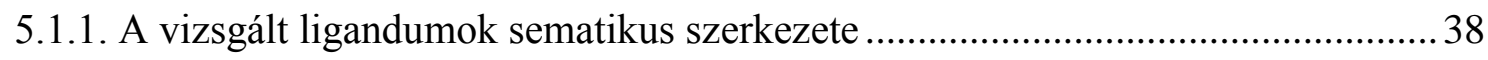

5.1.2. A ligandumok pH-potenciometriás és UV spektroszkópiai vizsgálata .................39

5.1.3. A ligandumok ${ }^{1} \mathrm{H}$ NMR spektroszkópiai vizsgálatai....................................... 40

5.1.4. A ligandumok CD spektroszkópiai vizsgálatai ............................................. 43

5.2. A ligandumok $\mathrm{Zn}^{2+}$-, és $\mathrm{Cd}^{2+}$-ionok komplexeinek vizsgálata.....................................45

5.2.1. A hisztidint nem tartalmazó ligandumok $\mathrm{Zn}^{2+}$-, és $\mathrm{Cd}^{2+}$-komplexei ....................45

5.2.1.1. Az ekvimoláris $\mathrm{Zn}^{2+}$-, és $\mathrm{Cd}^{2+}$-ionokat tartalmazó rendszerek vizsgálata..... 45

5.2.1.2. A PP ligandumot feleslegben tartalmazó rendszerek vizsgálata...................52

5.2.2. A hisztidint is tartalmazó $\mathbf{H S}$ ligandum $\mathrm{Zn}^{2+}$ - és $\mathrm{Cd}^{2+}$-komplexei.......................58

5.2.2.1. Az ekvimoláris $\mathrm{Zn}^{2+}$-, és $\mathrm{Cd}^{2+}$-iont tartalmazó rendszerek vizsgálata ..........58

5.2.2.2. A ligandumfelesleget tartalmazó rendszerek vizsgálata...............................62

5.2.3. A $\mathrm{Zn}^{2+}$-, és $\mathrm{Cd}^{2+}$-komplexek stabilitásainak összehasonlítása ............................68

5.3. A ligandumok $\mathrm{Hg}^{2+}$-ionokkal alkotott komplexeinek vizsgálata ...............................69

5.3.1. A hisztidint nem tartalmazó ligandumok $\mathrm{Hg}^{2+}$-komplexei.................................69

5.3.2. A HS ligandum $\mathrm{Hg}^{2+}$-komplexeinek vizsgálata .............................................. 81

5.4 A vizsgált ligandumok $\mathrm{Ag}^{+}$-ionokkal alkotott komplexei ...................................... 85 


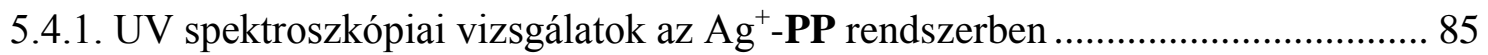

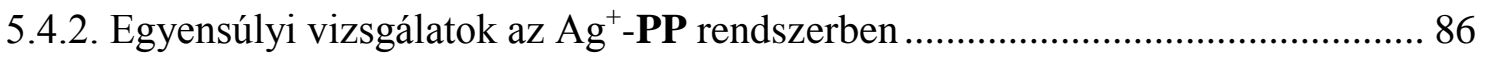

5.4.3. CD spektroszkópiai vizsgálatok az $\mathrm{Ag}^{+}-\mathbf{P P}$ rendszerben .................................... 87

5.4.4. NMR spektroszkópiai vizsgálatok az $\mathrm{Ag}^{+}-\mathbf{P P}$ rendszerben .................................... 88

6. Összefoglalás ................................................................................................................................... 92

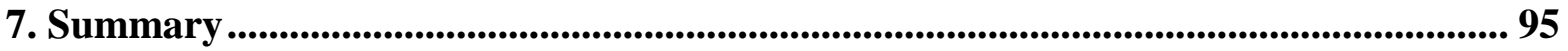

8. Irodalomjegyzék ......................................................................................................................................... 98

9. Közlemények listája ............................................................................................................ 106

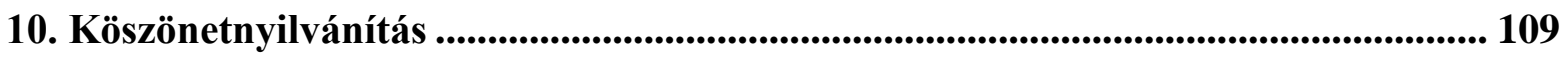

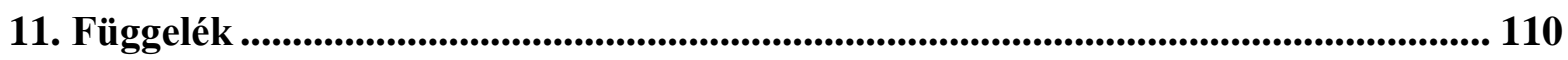




\section{Bevezetés}

Az átmenetifémek, mint például a mangán, vas, kobalt, nikkel, réz, cink, molibdén ionjai a biológiai rendszerek nélkülözhetetlen alkotóelemei. Ezek a fémionok megtalálhatók a metalloenzimek aktív centrumaiban, katalitikus kofaktorként részt vesznek hidrolitikus, illetve reverzibilis oxidációs és redukciós reakciókban, valamint az elektron transzfer folyamatokban is. Az élő szervezet specifikus fémion-fehérje komplexek kialakításával biztosítja a fémionok szelektív kiválasztását, így azok a megfelelő időpillanatban a megfelelő helyre kerülhetnek. Koncentrációjuk szük tartományon belül változhat, mennyiségük túlzott növekedése/csökkenése a sejtek károsodásához vezethet. Fontos tehát az optimális koncentráció fenntartása, ami a fémion-felvétel, -raktározás és -efflux megfelelő egyensúlyával érhető el [1].

A környezetünkben előforduló nehézfémek közül kifejezetten toxikusak a szoft karakterü Hg-, Cd-, Tl-, Pb-, és a hard fémek úgymint a Be-, vagy az Al-ionjai is. Az említett szoft fémionok az élő szervezetben található fehérjék szoft donorcsoportjaival (pl.: ciszteinek tiolcsoportjai) koordinációs kötések kialakítása révén megváltoztathatják azok szerkezetét ezért befolyásolhatják azok müködését.

A fémionok mérgező hatása általában ahhoz rendelhető, hogy hasonlóságuk révén létfontosságú elemeket szorítanak ki biológiai funkciót ellátó helyükröl és így fontos folyamatokat blokkolnak. Ilyen például a $\mathrm{Zn}^{2+} \leftrightarrow \mathrm{Cd}^{2+} ; \mathrm{Ca}^{2+} \leftrightarrow \mathrm{Pb}^{2+}, \mathrm{Cd}^{2+},{ }^{90} \mathrm{Sr}^{2+} ; \mathrm{Mg}^{2+} \leftrightarrow$ $\mathrm{Be}^{2+}, \mathrm{Al}^{3+}$ cseréje.

Az elemek toxikusságában meghatározó szerepe van azok aktuális kémiai formájának is. Például a féminok fémorganikus származékai, a bioalkilezett ionok, $\left(\mathrm{R}_{\mathrm{n}} \mathrm{M}^{+}\right)$sokkal mérgezőbbek, mint a hidratált szervetlen kationok. Ezen elemek/vegyületek eltávolítására az élő szervezetek különböző energiaigényes detoxifikáló rendszereket fejlesztettek ki.

1) Kevésbé toxikus formára alakítás enzimatikus úton $\left(\mathrm{pl} .: \mathrm{Hg}^{2+} \rightarrow \mathrm{Hg}^{0}\right)$

2) A töltéssel rendelkező fémionok bejutásának gátlása a sejtekbe biológiai membránok segítségével

3) A nemkívánatos helyen felhalmozódott fémionok eltávolítása ionpumpákkal

4) A mérgező fémionok megkötése és eltávolítása a keringési rendszerből speciális fehérjék által

A létfontosságú fémionok koncentrációjának szabályozása, a toxikus fémionok mérgező hatásának minimalizálása, valamint azok kiürítése folyamatos kontroll alatt történik. 
A bioszervetlen kémia eszközeit alkalmazva megtervezhetjük és előállíthatjuk a fémion-háztartás megfelelö müködéséhez szükséges fehérjék és enzimek modellvegyületeit. Ezen vegyületek fémkomplexeinek oldatszerkezet-vizsgálata segítségünkre lehet abban, hogy megismerjük a fémionok és biomolekulák közötti kölcsönhatásokat, a fémionok fehérjék szerkezetére gyakorolt hatását, a fehérjék fémion-szelektivitását. Ezt a disszertációmban a $\mathrm{Cu}^{+}$-ionok érzékelésében, valamint koncentrációjának szabályozásában szerepet játszó CueR fehérjék fémkötő részének modellezésén keresztül mutatom be. 


\section{Célkitüzés}

A sejtek fémion-háztartását olyan speciális fehérjék (mint például az általunk választott MerR család tagjai) tartják fenn, amelyek mind a létfontosságú, mind a toxikus fémionok mennyiségét hivatottak szabályozni. Müködésük a fémionok szelektív megkötésén alapul. Az ilyen regulátor fehérjék feladata például redoxi folyamatokat katalizáló enzimek, a fémionok szállításában, tárolásában, ürítésében részt vevő transzportfehérjék szintézise, amit akár transzkripciós szinten is képesek befolyásolni.

A $\mathrm{PhD}$ munkám célja egy egyértékü $\mathrm{d}^{10}$ fémionokra $\left(\mathrm{Cu}^{+}, \mathrm{Ag}^{+}, \mathrm{Au}^{+}\right)$szelektív transzkripciós regulátor fehérjék, a bakteriális CueR (V. cholerae és E. coli baktériumokból) fémionkötő tulajdonságainak felderítése volt. Annak érdekében, hogy a fehérje fémionszelektivitását jobban megértsük, vizsgálataink során ezen fehérje fémionkötő szakaszára fókuszáltunk.

Terveink között szerepelt, hogy a fémionkötő doméneket a fehérjékből kiemelve megvizsgáljuk, hogy peptid-szinten is tapasztalunk-e fémion-szelektivitást. Ezért szilárdfázisú szintézissel előállítottuk ezen peptidszakaszokat. A fent említett két fémkötő régió modellvegyületei az $\mathrm{N}$-, és C-terminálisan is védett PP: Ac-SCPGDQGSDCPI- $\mathrm{NH}_{2}$ és EC: Ac-ACPGDDSADCPI-NH $\mathrm{N}_{2}$ peptidek voltak. Mindkét szekvencia egymástól nyolc aminosav távolságra elhelyezkedő ciszteineket tartalmaz, így megfelelő ligandumok lehetnek szoft karakterü fémionok megkötésére.

O’Halloran és munkatársai kimutatták, hogy a CueR fehérje csak egyértékü, szoft karakterü fémionok megkötését követően mutat pozitív biológiai választ [2]. Ezért célszerünek találtuk az általunk előállított peptidek kétértékủ fémionokkal $\left(\mathrm{Zn}^{2+}-, \mathrm{Cd}^{2+}\right.$, és $\mathrm{Hg}^{2+}$-ionok) alkotott komplexeinek vizsgálatát, hogy kiderítsük, ezek a fémionok milyen erős kötést alakítanak ki, és hogyan befolyásolják a peptidek szerkezetét. Egyensúlyi mérésekkel részletesen tanulmányoztuk a képződő komplexek stabilitása közötti különbségeket, UV-, CD- és NMR spektroszkópiával pedig az egyes részecskék oldatbeli szerkezetét és a bennük előforduló koordinációs geometriákat.

A MerR család tagjai között találhatunk olyan fehérjét is, amely kétértékü fémionstressz hatására képes a szabályozó mechanizmust müködésbe hozni. Ilyen például a $\mathrm{Hg}^{2+}-$ szelektív MerR, vagy a $\mathrm{Zn}^{2+}$-érzékeny $\mathrm{ZntR}$, valamint a $\mathrm{Cd}^{2+}$-szabályozó CadR fehérje, melyeket a koordinációs szférában megjelenő ciszteinek mellett további potenciális donorcsoportok jelenléte (további ciszteinek, valamint hisztidinek) tesz alkalmassá a specifikus fémion-kötésre. 
Ezek alapján célul tủztük ki, hogy megvizsgáljuk, milyen hatása lehet a peptidek fémkötő képességére, a komplexek szerkezetére és stabilitására, ha szekvenciájukba további potenciális donorcsoportot juttatunk.

A módosítások során szintetizált ligandumok a PS: Ac-SCPGDQGSDCSI- $\mathrm{NH}_{2}$, amelyben a PP peptid C-terminális prolinját szerinre cseréltük, illetve a HS (Ac-SCHGDQGSDCSI-NH $\mathrm{N}_{2}$ ), melyben további módosításként az eddigi két cisztein és két aszparaginsav mellé potenciális donorcsoportként egy hisztidint is beépítettünk a molekulába. A prolinok számának csökkentésével a ligandum flexibilitásának változásáról is kaphatunk információt. A módosított peptidek vizsgálatát egy friss tanulmány is igazolja, amely szerint az egyértékü fémionokra szelektív CueR fehérje is érzékennyé tehető kétértékü fémionokra, ha a fémkötő részt úgy módosítják, hogy a koordinációs szféra közelében további potenciális donorcsoportok jelennek meg [3].

Hogy közelebb kerüljünk a fehérjében tapasztalt fémion-szelektivitás megértéséhez, vizsgálatokat végeztünk egyértékü $\mathrm{d}^{10}$ fémionnal $\left(\mathrm{Ag}^{+}\right)$is, majd a képződő komplexek szerkezetének és stabilitásnak összevetését végeztük el az említett kétértékű $\mathrm{d}^{10}$ fémionok peptidkomplexeivel. A peptidekkel történő részletes vizsgálatok reményeink szerint elősegíthetik annak a kérdésnek az eldöntését is, hogy a fehérjék szelektivitása kizárólag a fémion megkötésének erősségén múlik, vagy más tényezők is hozzájárulnak a szelektív müködéshez. 


\section{Irodalmi elózmények}

\subsection{A fémion-háztartás múködése, alapvető folyamatai}

Az élő szervezetek fémion-homeosztázisa (fémion-háztartása) biztosítja, hogy a szabad fémionok koncentrációja ne haladja meg a sejt számára toxikus szintet. Ha a sejteknek egy biokémiai folyamathoz fémionra vagy fémion-tartalmú enzimekre van szükségük, akkor az adott fémionnak megfelelő koncentrációban, a megfelelő időben és helyen kell jelen lennie. Ennek megvalósításához egy olyan egyensúlyi rendszer szükséges, amely szabályozza a fémionok felvételét, szállítását, tárolását, illetve ürítését. A prokarióták a sejtplazma fémion-koncentrációjának túlzott növekedésére (fémion-stressz), vagy csökkenésére (fémion-hiány) adott válaszként befolyásolják a fémion anyagcserét a 3.1.1 ábrán bemutatott folyamatok szabályzásán keresztül [4].

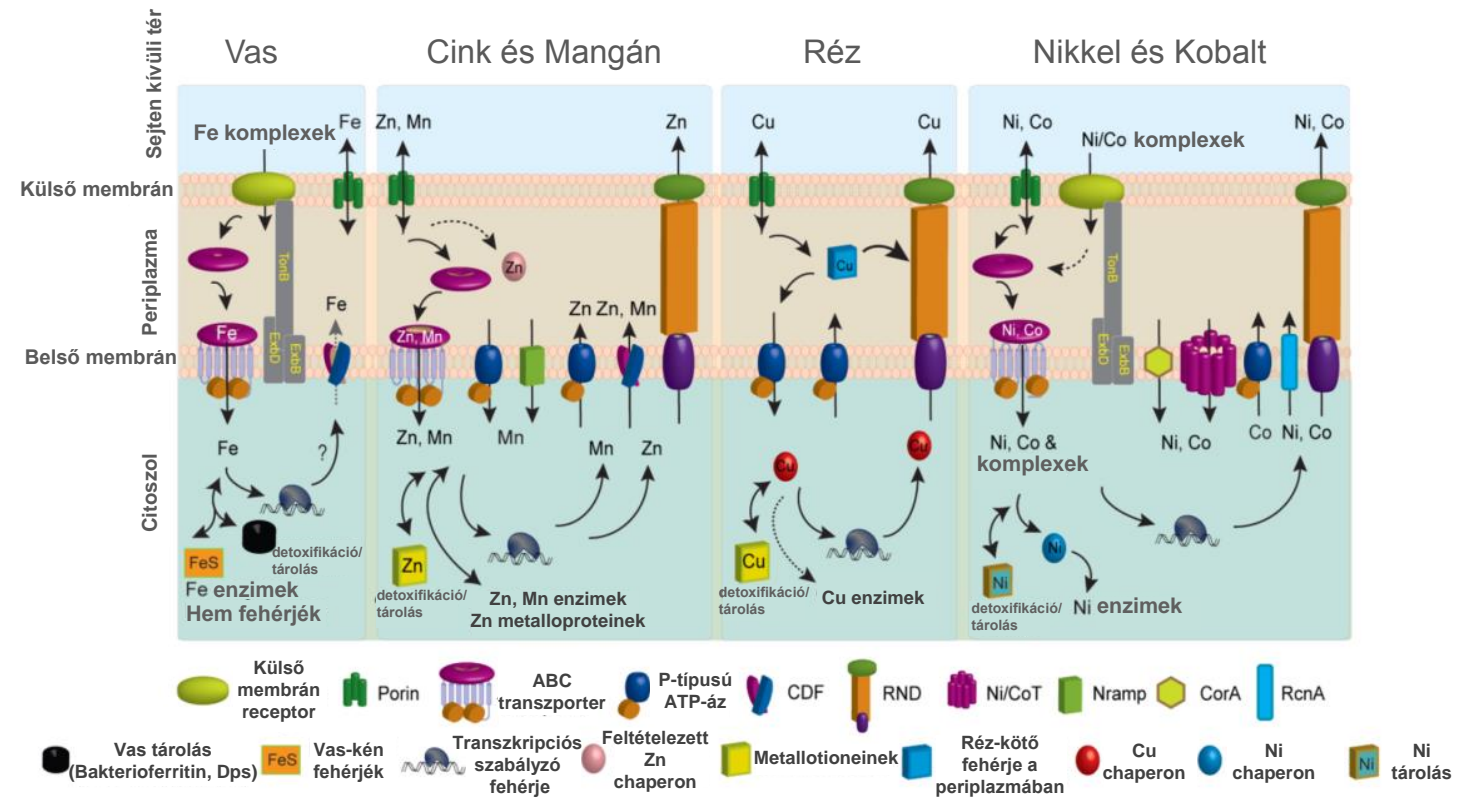

3.1.1. ábra: Néhány átmenetifém-ion homeosztázisának sematikus modellje [4]

A bakteriális fémion-homeosztázis során a fémion-felvétel a periplazmán keresztül történik. A periplazma az a térrész a külső és belső foszfolipid kettősrétegű membrán között, melyben enzimek és a transzportfolyamatok fehérjéi találhatók.

A baktériumok apoláris molekulákat passzív transzporttal (pl.: $\mathrm{CH}_{3} \mathrm{HgX}$ molekula diffúziója a membránokon keresztül [5]) képesek felvenni. A fémionok passzív transzport révén a porin fehérjék segítségével kerülnek a periplazmába, ahol vagy szabadon, vagy fehérjékhez kötve jutnak el a belső membránhoz. Ezt követően többféle módon kerülhetnek 
be a citoszolba. Passzív transzporttal, például Nramp [6-8] és CorA [9] specifikus csatornák részvételével, valamint aktív transzporttal, ami transzmembrán fehérjéken vagy ATP függő ioncsatornák által (ABC típusú fehérjék [10, 11], valamint P-típusú ATP-áz csatornák [12]) valósulhat meg.

A metalloproteinek létfontosságú kofaktorait jelentő fémionok bejutását követően, azokat speciális transzportmolekulák szállítják a sejten belül a felhasználás helyére, annak érdekében, hogy a szabad fémion-koncentráció ne haladja meg a sejt számára toxikus szintet.

Ezen kívül a szállításban, illetve tárolásban egyéb kismolekulák is részt vehetnek. Ilyen például a citoszolban található glutation (GSH), amely emellett a detoxifikációs folyamatokban is fontos szerepet játszik [13]. A szállításban közremüködhetnek olyan dajkafehérjék (chaperonok) [14] is, melyek a fémiont mindössze a megfelelö transzportfehérjéig, vagy a tárolás helyéig juttatják.

Mindezek ellenére előfordulhat a létfontosságú, illetve toxikus fémionok sejten belüli felhalmozódása, melyre a sejtek különböző védekező folyamatokkal reagálhatnak. Az egyik ilyen mechanizmus a fémion-felesleg indukálta metallotioneinek szintézise [15, 16]. A metallotioneinek fö funkciója a fémionok $\left(\mathrm{Zn}^{2+}, \mathrm{Cu}^{+}\right)$tárolása, azonban részt vesznek a fémion-mérgezést követő detoxifikációs folyamatokban is $\left(\mathrm{Cd}^{2+}, \mathrm{Hg}^{2+}\right)$. Megtalálhatók az állatokban, magasabb rendü növényekben, eukarióta mikroorganizmusokban és néhány prokariótában. Mivel a metallotioneinek ciszteinben gazdag fehérjék, a szoft karakterü fémionokat, mint például $\mathrm{Cu}^{+}-, \mathrm{Zn}^{2+}-, \mathrm{Cd}^{2+}-, \mathrm{Hg}^{2+}-, \mathrm{Ag}^{+}$-ionokat szelektíven kötik meg klaszterszerkezetben (3.1.2. ábra).

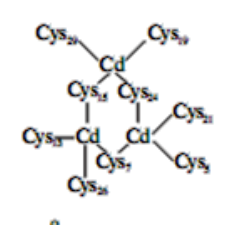

$\beta$

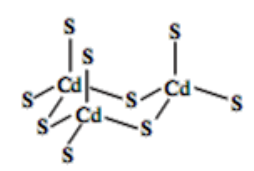

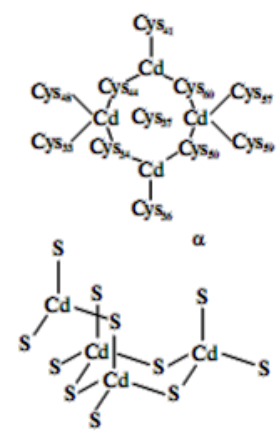

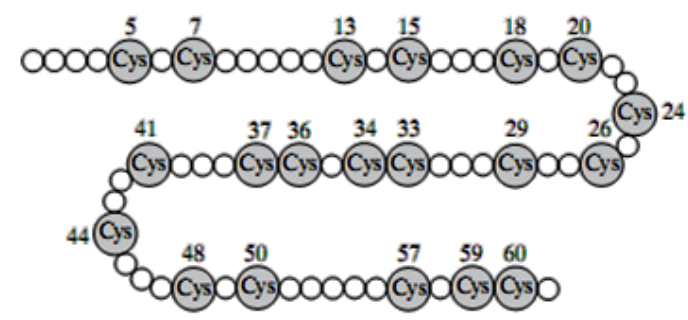

3.1.2. ábra: A metallotioneinek szerkezeti sajátosságai (W. Kaim, B. Schwedereski: Bioorganic chemistry: Inorganic elements of chemistry of life, New York, 1994,17.4 ábra, 337. oldal alapján)

A metallotioneinekben leggyakrabban előforduló jellegzetes aminosav-mintázatok a -Cys-Cys-, -Cys-X-Cys-, -Cys-X-X-Cys-, amelyekben az X bármely más aminosavat jelölhet. A metallotioneinek manapság elfogadott csoportosítását Binz és Kagi mutatta be 2001-ben. Eszerint 16 csoportba sorolhatók előfordulásuk, valamint a ciszteinek eloszlása és mintázata alapján [17]. 
A metallotioneinekkel analóg fitokelatinok a növényekben található rövid, ciszteinben gazdag peptidek, melyek alapja a ( $\gamma$-Glu-Cys) ${ }_{n}$ Gly szekvencia, melyben n 2 és 11 között változhat [18]. Funkciójuk a toxikus fémionok megkötése és elkülönítése.

Mérgező fémionok hatástalanításában/átalakításában (enzimatikus) redoxifolyamatokat katalizáló enzimek is részt vesznek. Ilyen például a citoszolban található MerA, amely a $\mathrm{Hg}^{2+}$-ionokat $\mathrm{Hg}^{0}$-vá képes redukálni, vagy a periplazmában található $\mathrm{CueO}$, mely a $\mathrm{Cu}^{+}$-ionokat kevésbé toxikus $\mathrm{Cu}^{2+}$-ionokká oxidálja.

A fémionok periplazmába, illetve a sejten kívüli térbe ürítéséröl specifikus és nemspecifikus fehérjék gondoskodnak, mint például a P-típusú ATP függő transzportfehérjék [12], valamint egyéb membránfehérjék (Cation Diffusion Facilitators (CDFs) [19], továbbá RND (Resistance-Nodulation-cell Division) transzporter fehérjék [20]).

\subsection{A bakteriális fémion-szabályzó fehérjék fajtái, funkciói}

A fémionháztartás meglehetősen bonyolult szabályozásáért felelös folyamatok finomhangolása DNS szinten is megvalósítható. A bakteriális fémion-homeosztázisban meghatározó szerepet töltenek be olyan speciális fehérjék, melyek képesek transzporterek, sejten belüli kelátorok (tárolók) és detoxifikáló enzimek kifejeződését szabályozni a transzkripciótól (a sejt kromoszomális DNS-éről képződő egyszálú tRNS szintézise) egészen a transzlációig (a fehérje kifejeződése) [21-23].

A két leggyakoribb szabályzó mechanizmus közül az első a transzkripciós aktiváció (3.2.1. ábra A), mely során a regulátor fehérje specifikusan kötődik a szabályozni kívánt DNS szakaszhoz, ezzel megakadályozva az RNS polimeráz müködését.

Megfelelő indukáló anyag (jelen esetben a felhalmozódott fémionok) képes kötődni az aktivátorhoz melynek hatására megváltozik a fehérje szerkezete. Ez a hozzá kötődő DNS szerkezetében is változást indukál, majd ezt követően az RNS polimeráz már akadálytalanul müködhet. Ezen az elven müködnek például a felesleg/toxikus fémion eltávolítását/átalakítását szabályzó MerR fehérjék is [24-27].

A másik gyakran előforduló szabályzó mechanizmus a represszió (3.2.1. ábra $B, C$ ), melynek két típusát különböztetjük meg. A közvetlen mechanizmus esetén ( $B$ ábra) a represszor a DNS-hez kötődve inaktiválja a transzkripciót, de indukáló anyag (például fémion) jelenléte megszünteti a represszor sztérikus gátlását (ArsR [28-32] illetve a CsoR [33-35] család fehérjéi, valamint a réz és cink homeosztázisban fontos szerepet játszó CopY [36] és TetR [37] fehérjék). 


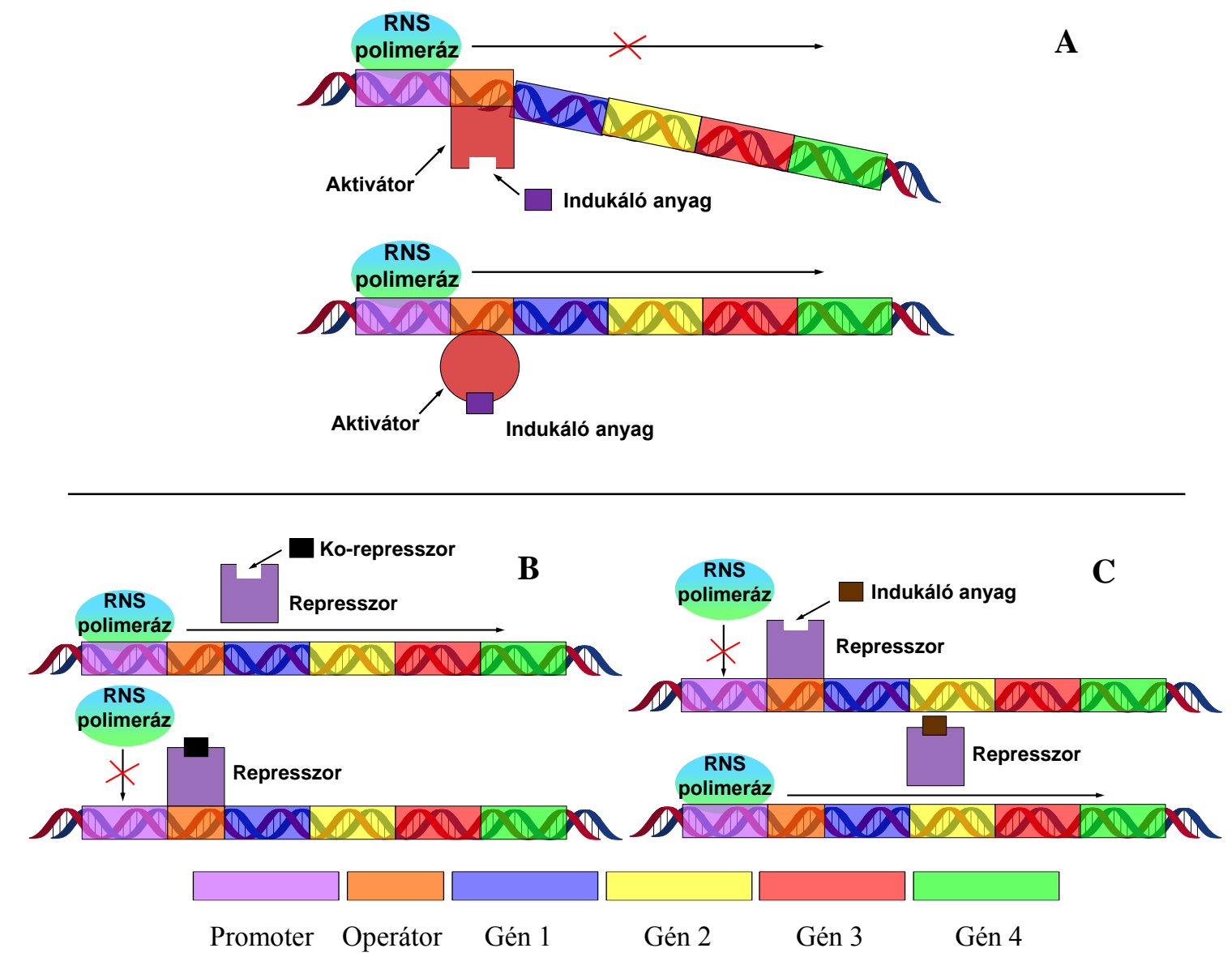

A

3.2.1. ábra: A transzkripciós szabályzás főbb fajtái (A: aktiváció; B: represszió; C: ko-represszió) A promoter operátor és a Gén1 - Gén4 szakaszokat együttesen operonnak hívjuk. A promoter szakasznál kötődik az RNS polimeráz. Az operátor régióban a szabályzást végző fehérje kötődik a DNS-hez. ( Gén 1, Gén 2 és Gén 3 az adott fémion eltávolításához szükséges fehérjéket kódoló génszakaszok)

Közvetett mechanizmus esetén ( $C$ ábra) egy ko-represszor (például fémion) szükséges ahhoz, hogy a represszor aktiválódjon és a DNS-hez kötve akadályozza a transzkripciót $\left(\mathrm{a} \mathrm{Mn}^{2+}-, \mathrm{Fe}^{2+}-\mathrm{Ni}^{2+}\right.$ - és $\mathrm{Zn}^{2+}$-ionok felvételéért felelős Fur család tagjai [38, 39], valamint a $\mathrm{Ni}^{2+}$-ion specifikus NikR fehérje [40]).

\subsection{A MerR fémion szabályzó fehérjék családja}

A MerR fehérjék családja (mely a $\mathrm{Hg}^{2+}$-ionok szabályzásáért felelős Mercuric resistance operon Regulatory protein-ről kapta a nevét) olyan transzkripciós aktivációs faktorok összessége, melyek fémionok, gyökök, illetve kis szerves molekulák koncentrációját szabályozzák a bakteriális sejtekben [26, 27]. Tagjai többek között a $\mathrm{Cd}^{2+}-$, $\mathrm{Zn}^{2+}-, \mathrm{Co}^{2+}-, \mathrm{Cu}^{+}-, \mathrm{Ag}^{+}-, \mathrm{Au}^{+}-, \mathrm{Hg}^{2+}$-, és $\mathrm{Pb}^{2+}$-ionok érzékeléséért felelősek [41-49]. A toxikus fémionok eltávolítását végző fémion-függő MerR fehérjék fémkötő részleteit mutatja a 3.3.1. ábra. 


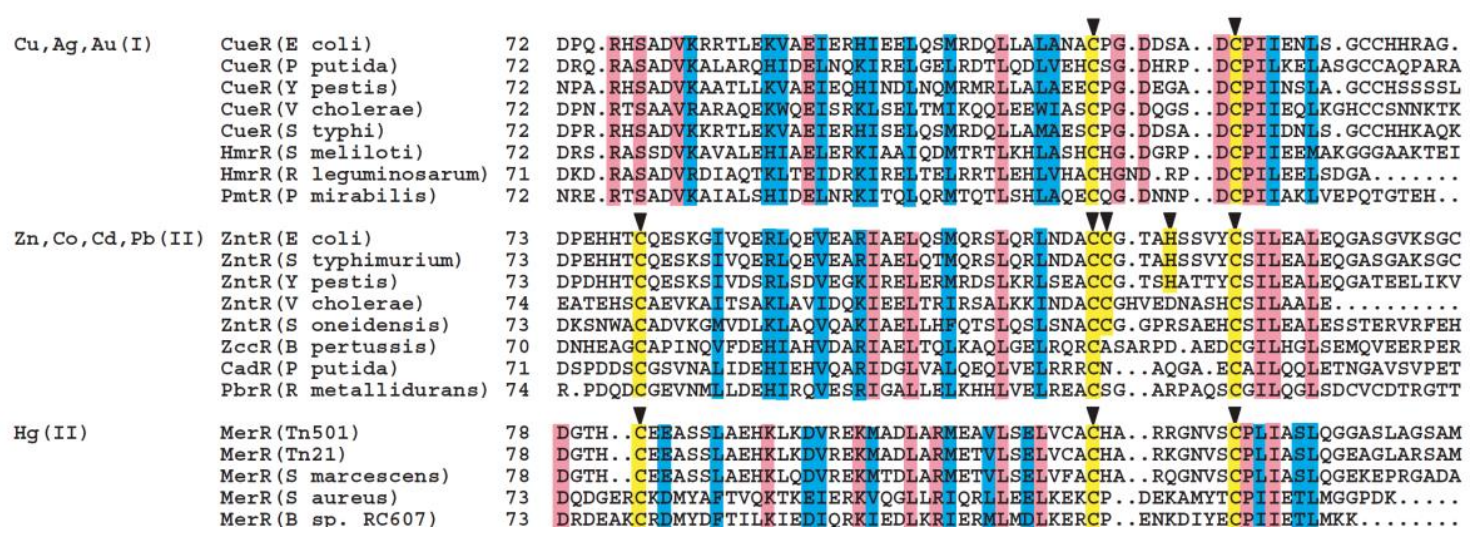

3.3.1. ábra: Néhány MerR családba tartozó fehérje C-terminális doménjének részlete [2] A sárga kiemelés (fekete nyilak) a fémion kötésében résztvevő aminosavakat mutatja. A szekvenciák közötti hasonlóságot a kék és rózsaszín kiemelések jelzik.

A MerR fehérjékre jellemző a nagy szekvenciabeli és szerkezeti hasonlóság, valamint ezek mindegyike aktivációs módon szabályozzák a fehérje kifejeződést. Szerkezetükről általánosságban elmondható, hogy a fehérje N-terminális végén található egy hélix-kanyarhélix- $\beta$-kanyar DNS-kötő motívum [27] (3.3.2. ábra), amelyet egy viszonylag hosszú dimerizációs hélix követ, amin keresztül a fehérje két monomer egysége kapcsolódik egymáshoz. Jelentős diverzitás a C-terminális fémion-kötő domén szekvenciájában tapasztalható, ami a fémionokkal szembeni szelektivitásért felelős [50]. Megfigyelhető azonban, hogy ebben a régióban a szoft karakterü fémionokhoz kötődő ciszteinek minden esetben ugyanabban a pozícióban foglalnak helyet.

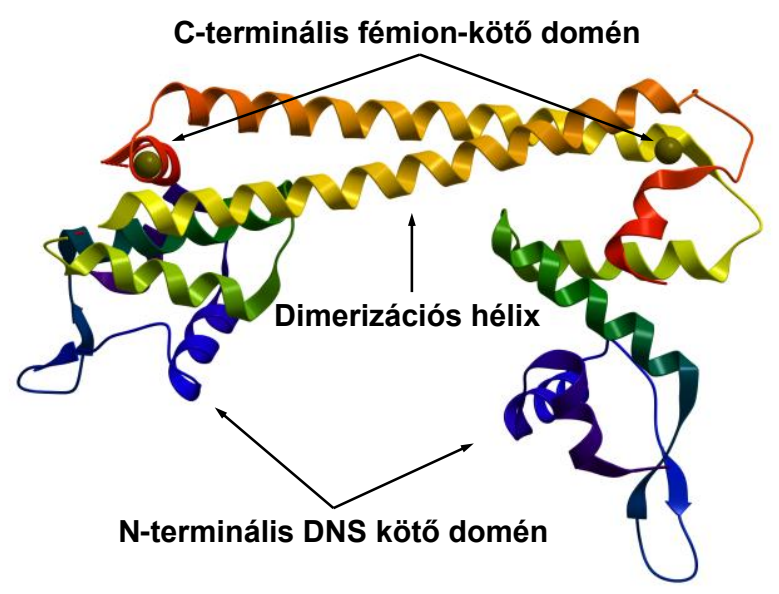

3.3.2. ábra: A MerR családba tartozó CueR fehérje szerkezete (PDB: 1Q05 [2])

\subsection{1. $\mathrm{A} \mathrm{Hg}^{2+}{ }^{2+}$ szabályozó MerR fehérje}

A MerR regulátorok koordinációs sajátságait elöször magán a MerR fehérjén vizsgálták. Ez a fehérje 144 aminosavból áll, melyben a $\mathrm{Hg}^{2+}$-ionok koordinációjáért a ${ }^{82} \mathrm{Cys},{ }^{117} \mathrm{Cys}$ és a ${ }^{126} \mathrm{Cys}$ aminosavak felelösek [51]. 
EXAFS [52, 53] és ${ }^{199} \mathrm{Hg}-\mathrm{NMR}$ [54, 55] vizsgálatokkal bizonyították, hogy a három cisztein tiolátcsoportjain keresztül síkháromszöges geometriával kötődik a $\mathrm{Hg}^{2+}$-ionhoz, átlagosan 2,43 Å Hg-S távolsággal. A MerR fehérje ultraszenzitív [56] szabályozó mechanizmusát Ansari és munkatársai írták le [57, 58], amely a többi MerR családba tartozó fehérje feltételezett mechanizmusával is nagy hasonlóságot mutat. A következőkben bemutatott folyamat elve alapján működnek a ZntR és CueR fehérjék is.

A normál sejtműködés során az RNS polimeráz a merR génről MerR szabályzó fehérjét kódoló RNS szakaszt szintetizál, hogy a transzlációt követően növelje a MerR sejten belüli koncentrációját. A MerR fehérje kifejezését követően az apofehérje $\mathrm{N}$-terminális vége a DNS operátor régiójához kötődik a -35 és -10 promoter helyek között elhelyezkedő 19-20 bázispár hosszúságú toldalék szakaszon. Ezzel elnyomja a merR régió transzkripcióját, visszaszorítva a további MerR szintézist. A DNS-hez kapcsolódó apofehérje csak gyenge kölcsönhatást tesz lehetővé az RNS polimeráz és a DNS között, így a transzkripció nem lehetséges (3.3.1.1. ábra A). Ha azonban a megfelelő fémion $\left(\mathrm{Hg}^{2+}\right.$-ion a MerR transzkripciós aktivátornál) koordinálódik a fehérjéhez, annak konformációja megváltozik, aminek hatására a DNS szerkezete torzul, a kettős szál "kicsavarodik". Ezzel a kötőhely alkalmassá válik az RNS polimeráz számára, és megkezdődhet a transzkripció (3.3.1.1. ábra B) [27], ami a detoxifikációhoz szükséges fehérjék képződését eredményezi.
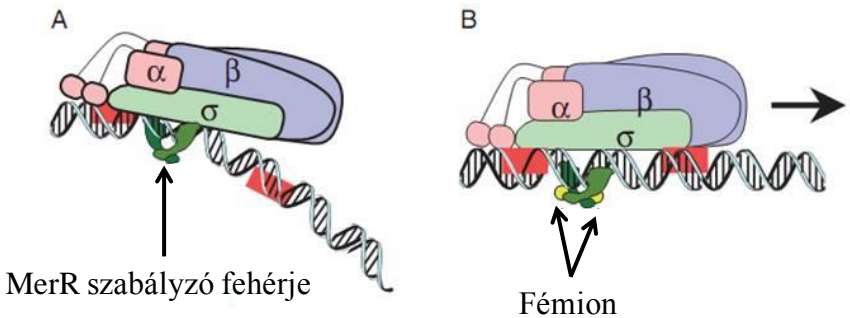

3.3.1.1. ábra: A MerR transzkripciós aktivátor müködési elve $[57,58]$

Ha a sejtben a szabad fémion mennyisége az optimális értékre csökken, akkor a $\mathrm{Hg}^{2+}$-(MerR $)_{2}$ komplex disszociál a DNS-ről, melynek helyére egy másik, fémiont nem tartalmazó (MerR) $)_{2}$ dimer fehérje kötődik (ennek nagyobb az affinitása a DNS-hez), visszaállítva ezzel a normál sejtmüködést.

\subsubsection{A $\mathrm{Zn}^{2+}$ - és $C d^{2+}$-érzékeny ZntR szabályzó fehérje}

A $\mathrm{Zn}^{2+}-, \mathrm{Cd}^{2+}$-, és $\mathrm{Pb}^{2+}$-ionok eltávolításában fontos szerepet játszó ZntA P-típusú ATP-függő szállítófehérje [59-61] szintézisét a szintén MerR családba tartozó $\mathrm{Zn}^{2+}$-szelektív ZntR ( $\underline{\mathbf{Z n}}$ transporter $\underline{\text { Regulator}) ~ f e h e ́ r j e ~ v e ́ g z i ~[49] . ~}$ 
Ez a szabályozó folyamat nagy hasonlóságot mutat a korábban tárgyalt $\mathrm{Hg}^{2+}$-függő $\mathrm{MerR}$ fehérje aktivációs mechanizmusával [62].

A $\mathrm{ZntR}$ fehérje $\mathrm{Zn}^{2+}$-érzékenységét vizsgálva Outten és munkatársai arra az eredményre jutottak, hogy a $\mathrm{Zn}^{2+}$-ionok mindösszesen $10^{-15} \mathrm{M}$ koncentrációja elegendő a transzkripciós aktivációhoz [63]. A MerR fehérjével 52\%-ban egyező szekvenciájú ZntR 141 aminosavból áll, hordozza a MerR család fehérjéire jellemző szerkezeti sajátságokat [2]. A fehérjében mindkét fémion-kötő domén két $\mathrm{Zn}^{2+}$-ion megkötésére képes, négy cisztein és egy hisztidin koordinációja révén (3.3.2.1. ábra).

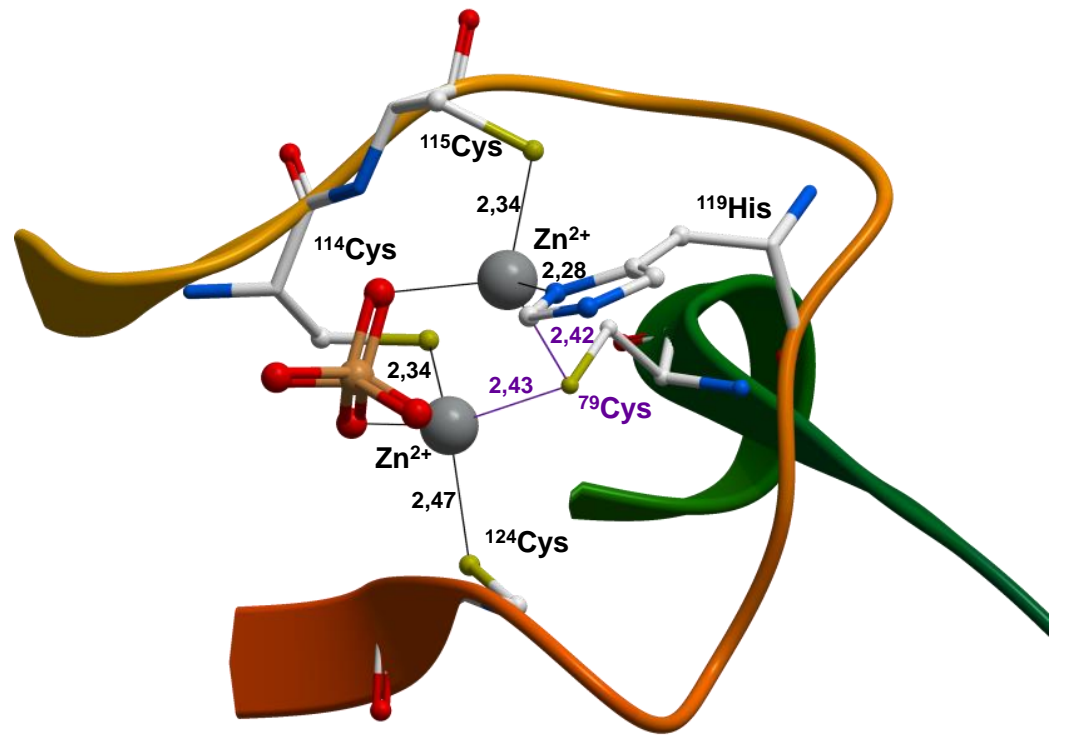

3.3.2.1. ábra: Az E. coli ZntR fehérje fémkötő doménje (PDB: 1Q08 [2]) (A kötéstávolságokat angströmben jelöltem. A jelen kristályszerkezetben található egy foszfát-ion is, amely részt vesz a koordinációban)

A kétmagvú fémion-kötő doménben mindkét $\mathrm{Zn}^{2+}$-ion körül tetraéderes geometriájú a koordinálódó csoportok elrendeződése. Az egyik $\mathrm{Zn}^{2+}$-ion kötésében a ${ }^{114} \mathrm{Cys}$ és ${ }^{124} \mathrm{Cys}$ aminosavak vesznek részt, míg a másikhoz a ${ }^{115}$ Cys és a ${ }^{119}$ His koordinálódik. A másik monomer egységről származó ${ }^{79} \mathrm{Cys}$ hídligandumként köti össze a két fémcentrumot. A His és Cys aminosavak fontos szerepet játszanak a $\mathrm{Zn}^{2+}$-ionok kötésében, ugyanis ha mutáció révén bármelyik koordinálódó aminosavat kicserélték, csökkent a $\mathrm{Zn}^{2+}$-ionok által kiváltott biológiai válasz [64]. A kristályszerkezetben jelenlévő foszfát-ion oxigén donoratomjaival alakít ki kötést a $\mathrm{Zn}^{2+}$-ionnal.

\subsubsection{A Cu+ ${ }^{+}$és $\mathrm{Ag}^{+}$-függö CueR szabályzó fehérje}

A bakteriális sejtek egyik esszenciális kofaktora a réz, azonban nagy mennyiségben citotoxikus hatású. A sejten belüli/kívüli koncentráció-viszonyok határozzák meg a réz-ion transzportjának irányát, amelyet a 3.3.3.1. ábra szemléltet. 


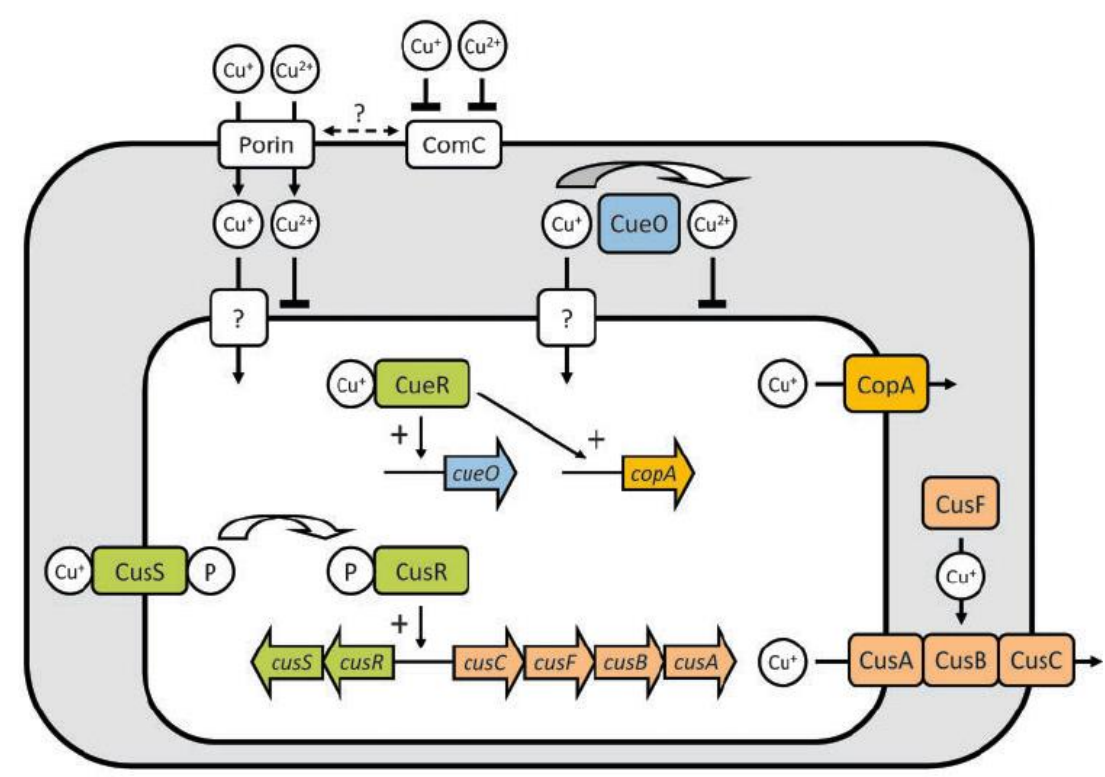

3.3.3.1. ábra: $\mathrm{A} \mathrm{Cu}^{2+} / \mathrm{Cu}^{+}$homeosztázis az E. coli baktériumban [35]

Az E. coli baktériumban a $\mathrm{Cu}^{2+} / \mathrm{Cu}^{+}$-ionok a porin fehérjéken keresztül jutnak be a periplazmába. Innen azonban csak a $\mathrm{Cu}^{+}$-ionok jutnak a citoszolba, ahol két detoxifikáló rendszer felel a felhalmozódásuk elleni védelemért.

(I) A cusRS és cusCFBA operon szabályozásán alapuló rendszer. A CusS membránfehérje a periplazmában érzékelt $\mathrm{Cu}^{+}$-ionokhoz kötődik. Ennek következtében foszforilálja a CusR fehérjét, aktiválva a cusRS és cusCFBA operonokat, és elindítva a megfelelő gének transzkripcióját.

(II) A copA és cueO operonok szabályozásán alapuló rendszer. A CopA egy ATPfüggő P-típusú transzporter fehérje [65], amely a copA gén transzkripcióját követően képződik és a $\mathrm{Cu}^{+}$-ion szállítását végzi a citoszolból a periplazmába. A $\mathrm{CueO}$ fehérje pedig egy oxidáz [66], amely a $\mathrm{Cu}^{+}$-ionokat képes oxidálni kevésbé mérgező $\mathrm{Cu}^{2+}$-ionokká.

Megvédi ezáltal a $\mathrm{Cu}^{+}$-ionokra érzékeny enzimeket (pl.: alkalikus foszfatáz) a periplazmában. E folyamatok szabályozását a CueR ( $\underline{\mathbf{C u}} \underline{\mathbf{E} f f l u x} \underline{\mathbf{R}}$ egulator) fehérje végzi.

A CueR [35, 45, 48, 67] transzkripciós aktivátor rendkívüli érzékenységét Changela és munkatársai in vitro kísérletekkel bizonyították, miszerint $\mathrm{Cu}^{+}$-ionok jelenlétében már $10^{-21} \mathrm{M}$ koncentráció mellett is mérhető a transzkripciós válasz. Ez az aktivitás nagy koncentrációban alkalmazott glutation (GSH) hatására sem csökkent, azonban $\sim 10^{-3} \mathrm{M}$ koncentrációjú cianid-ionok jelenlétében visszaszoríthatónak bizonyult [68, 69]. Ugyanezt a kísérletet $\mathrm{Hg}^{2+}$ - és $\mathrm{Zn}^{2+}$-ionok jelenlétében elvégezve biológiai választ nem tapasztaltak, azonban $\mathrm{Ag}^{+}$- és $\mathrm{Au}^{+}$-ionok hatása $\mathrm{Cu}^{+}$-ionéhoz hasonló volt. 
A CueR fehérje 137 aminosavból áll, szekvenciájának egyezése a ZntR fehérjével 37\%, míg a MerR fehérjével 28\%. Changela és munkatársai megfejtették a $\mathrm{Cu}^{+}$-iont tartalmazó CueR dimer kristályszerkezetét [2], amely alapján a $\mathrm{Cu}^{+}$-ion koordinációjában a ${ }^{112}$ Cys és ${ }^{120}$ Cys aminosavak (analóg a ZntR ${ }^{112}$ Cys és ${ }^{124}$ Cys aminosavakkal) vesznek részt. A Cu${ }^{+}-\mathrm{S}$ kötéstávolság 2,13 Å-nek, az S-Cu+-S kötésszög pedig $176^{\circ}$-nak adódott, amellyel jó összhangban vannak egy későbbi EXAFS kísérlet eredményei [70]. További aminosavoldalláncok koordinációját a $\mathrm{Cu}^{+}$-ionhoz kizárták. A másik monomer-egységről származó ${ }^{77} \mathrm{Ser}$ a $\mathrm{Cu}^{+}$-ion koordinációjában nem vesz részt, azonban a fémion-kötő régió konformációjának kialakításában fontos szerepet játszhat hidrogénkötések kialakításán keresztül (3.3.3.2. ábra).

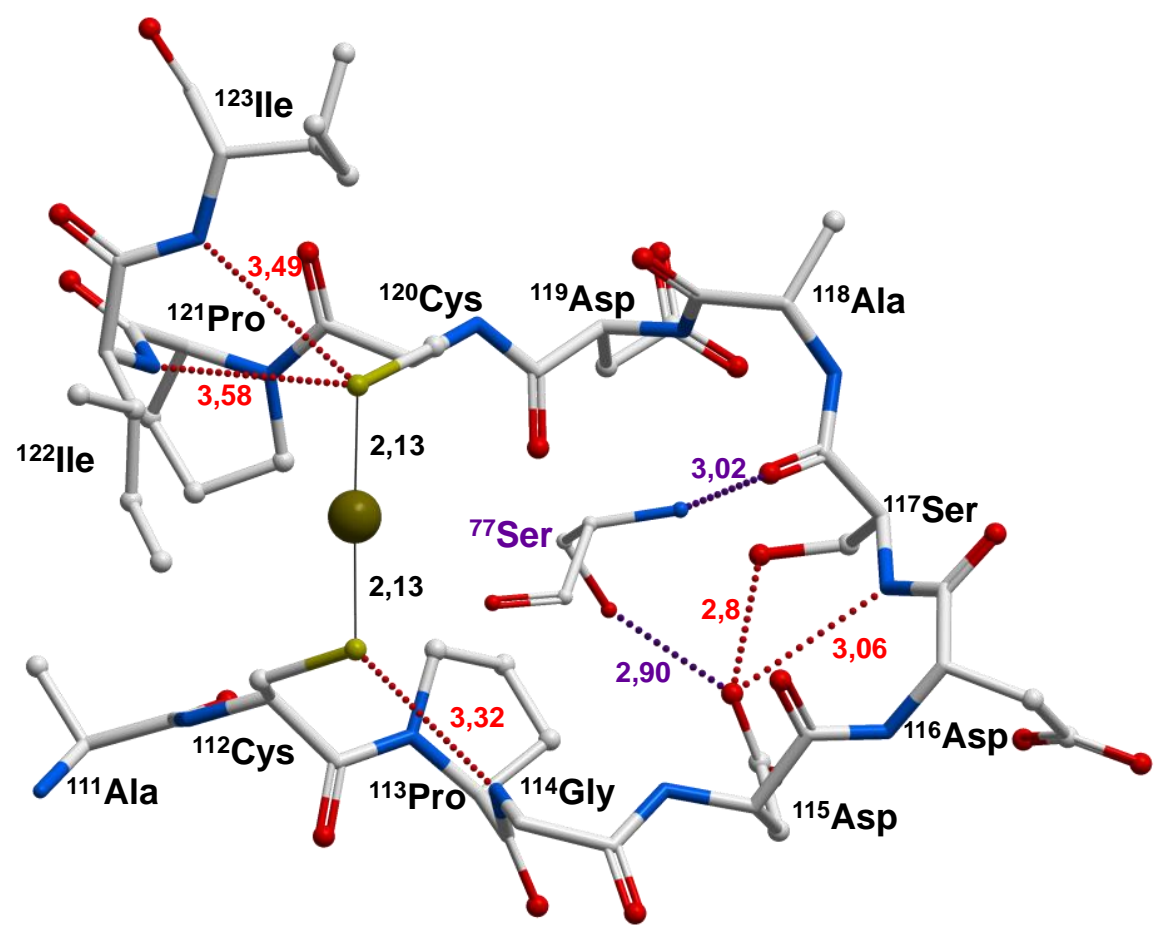

3.3.3.2. ábra: Az E. coli CueR fehérje fémkötő doménjének szerkezete (PDB: 1Q05 [2]) (A kötéstávolságokat angströmben, az intermolekuláris hidrogénkötéseket lila, míg az intramolekuláris hidrogénkötéseket piros színnel jelöltem)

A $\mathrm{Cu}^{+}$-ion és a deprotonált tiolcsoportok között kialakuló kölcsönhatás következményeként negatív töltéstöbblet alakul ki a koordinációs szférában. Az elektronsűrüség csökkentése érdekében a fenti ábrán látható módon másodlagos kötések alakulnak ki. A ${ }^{120}$ Cys tiolátcsoportja hidrogénkötést alakít ki a tőle 3,5 Å távolságra lévő izoleucin amid-protonokkal, míg a ${ }^{112}$ Cys oldallánca a ${ }^{114}$ Gly amid-hidrogénjével létesít kölcsönhatást. A Cys-Pro motívum megjelenése olyan kedvezményezett szerkezetet alakít ki, amely szintén csökkenti a negatív töltéstöbbletet [71]. 
Továbbá az egyik monomer egység ${ }^{81}$ Lys aminosavának pozitív töltésű oldallánca a számottevő távolság $(5,57 \AA)$ ellenére is közremüködhet a másik monomer ciszteinjein lévő negatív töltés kompenzálásában (3.3.3.3. ábra).

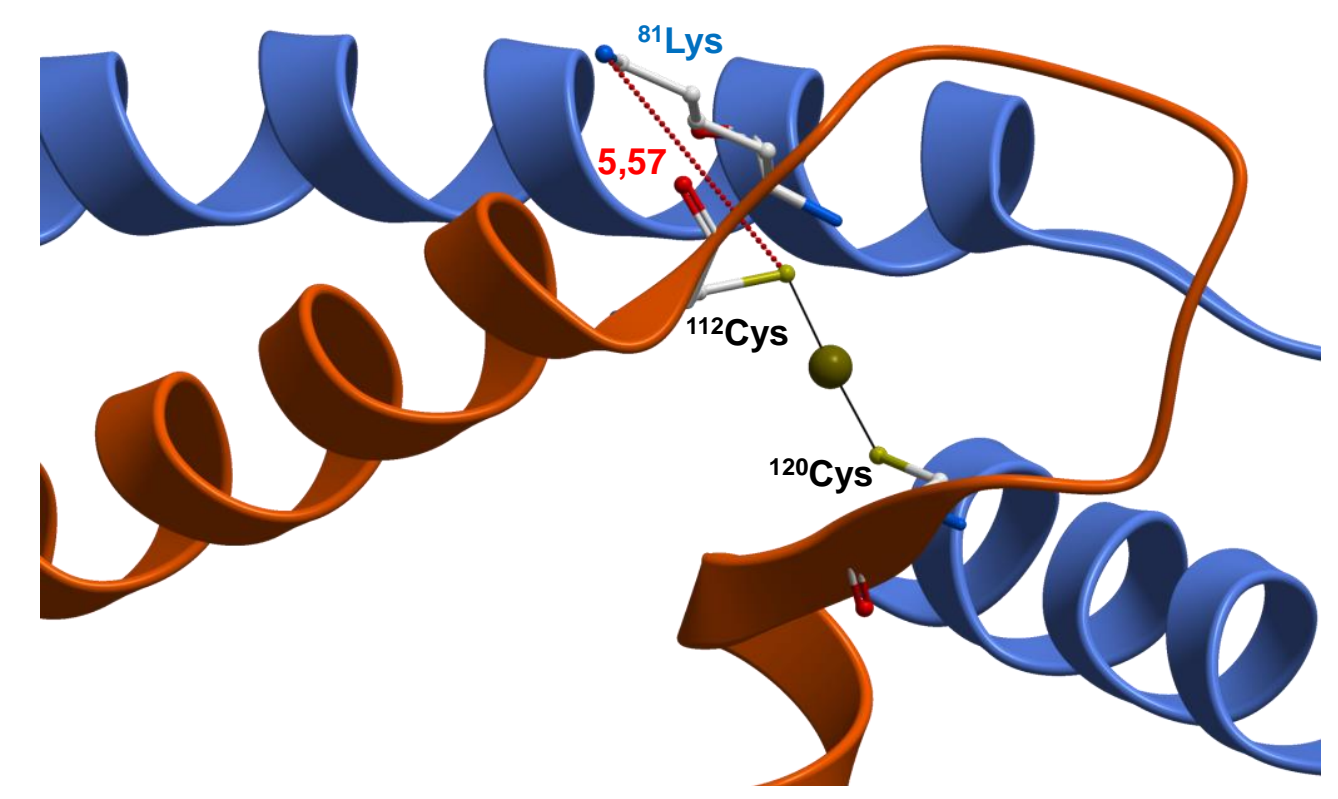

3.3.3.3. ábra: Az E.coli CueR fehérjében a $B$ monomer egységben (narancs) lévő cisztein lehetséges kölcsönhatása az A monomer egységben (kék) található ${ }^{81}$ Lys pozitív oldalláncával (A kötéstávolságokat angströmben jelöltem)

\subsubsection{A szabályozó fehérjék összevetése fémkötö sajátságaik alapján}

A fémion-kötő doménekben tapasztalt különbségek magyarázatot adhatnak a fehérjék eltérő szelektivitására. A MerR család tagjai közül az egy vegyértékű fémionokra érzékeny CueR fehérjében a ${ }^{112} \mathrm{Cys}$ és ${ }^{120} \mathrm{Cys}$ aminosavak alakítják ki a fémionok körüli lineáris koordinációs geometriát. $\mathrm{A} \mathrm{Hg}^{2+}$-ionokra érzékeny MerR fehérjében trigonális koordinációs geometria figyelhető meg, míg a ZntR fehérjében a fémion-kötő hurokban hisztidin és ciszteinek részvételével két koordinációs központ jön létre, melyben két $\mathrm{Zn}^{2+}$-iont egy cisztein hídligandumként köt össze, kialakítva a fémionok körüli tetraéderes szerkezetet.

A fémion-kötő rész szerkezetét befolyásolhatja inter-, és intramolekuláris hidrogénkötések kialakulása is. Érdekes azonban, hogy Changela és munkatársai szerint a fémion-kötő doménhez térben közeli ${ }^{77}$ Ser részvételével kialakuló hidrogénkötések meghatározóak a koordinációs környezet kialakulásában [43].

Ezzel ellentétben egy friss tanulmány szerint [3] a ${ }^{77}$ Ser $/{ }^{77}$ Ala csere nem változtatja meg a CueR fehérje szelektivitását és érzékenységét sem az egyértékü fémionokra. Azonban a szerin/cisztein csere hatására a CueR fehérje kétértékü fémionokra is érzékeny lett.

Mivel a fémionok megkötésében szerepet játszó aminosavak a szekvenciában egymáshoz viszonylag közel találhatók, érdekes lehet részletesebben megvizsgálni a 
ciszteint és más szoft fémionok számára potenciális donorcsoportokat is tartalmazó molekulák/peptidek koordinációs sajátságait.

\subsection{A cisztein és a cisztein-tartalmú peptidek fémkomplexei}

Az aminosavak, peptidek, valamint a fehérjék az aminosav-olalláncok révén képesek fiziológiás körülmények között fémionok megkötésére. Amíg a makromolekulák fémkötő sajátságait egyértelműn meghatározza azok szerkezete, addig a kismolekulák jobban képesek a fémion koordinációs kémiai viszonyaihoz alkalmazkodni. Ahhoz, hogy jobban megértsük a fehérjék kölcsönhatását fémionokkal, először alkotóelemeik, az aminosavak és peptidek fémion-kötő tulajdonságát érdemes megvizsgálni [72]. Mivel a CueR fehérje a cisztein tiolcsoporjain keresztül érzékeli a fémionokat, ezért az alábbiakban elsősorban ezen aminosav koordinációs sajátságaira térünk ki részletesebben.

\subsubsection{Cisztein és egyéb cisztein-származékok $d^{10}$ fémionokkal alkotott komplexei}

A cisztein (Cys vagy C) kéntartalmú aminosav. Három protonálódási folyamattal rendelkezik: karboxilcsoport $(\alpha-\mathrm{COOH}) \mathrm{p} K_{\mathrm{s}} \sim 2,0$ aminocsoport $\left(\alpha-\mathrm{NH}_{3}{ }^{+}\right) \mathrm{p} K_{\mathrm{s}} \sim 10,3$ továbbá az oldallánci tiolcsoport (-SH) $\mathrm{p} K_{\mathrm{s}} \sim 8,2-9,2$ [73]. A cisztein könnyen oxidálódik diszulfid hidas szerkezetü cisztinné. A tiolcsoport szoft karakterü, meglehetősen nagy affinitást mutat szoft jellegü átmenetifém-ionokhoz. Míg potenciális oldallánci donorcsoportot nem tartalmazó aminosavak aminosav-típusú $\left\{\mathrm{NH}_{2}, \mathrm{COO}^{-}\right\}$koordinációval kötődnek a fémionokhoz, addig a cisztein tiolcsoportja is részt vesz a komplexek kialakításában.

Egy kanadai kutatócsoport a 2000-es években $\mathrm{Hg}^{2+}$ - és $\mathrm{Cd}^{2+}$-ionok $\mathrm{N}$-acetil-cisztein (NAC, 3.4.1.1. ábra), L-cisztein (Cys) és penicillamin (PEN, 3.4.1.1. ábra) komplexeit vizsgálta különböző spektroszkópiai (EXAFS, Raman, ${ }^{113} \mathrm{Cd} /{ }^{199} \mathrm{Hg}-\mathrm{NMR}$ ) módszerekkel [74-78].
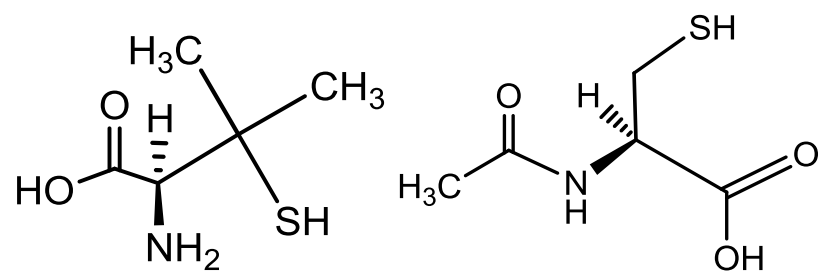

3.4.1.1. ábra: A penicillamin (PEN) és az N-acetil-cisztein (NAC) szerkezeti képlete

A $\mathrm{Cd}^{2+}$-ionok $\mathrm{pH}=7,5$ környékén 1:2 fémion:Cys arány mellett $\mathrm{CdL}_{2}$ összetételü, torzult tetraéderes komplexeket képeznek, melyekben a tiolátcsoportok koordinációja mellett 
amino- és karboxilátcsoportok $\left\{2 \times \mathrm{S}^{-}, \mathrm{NH}_{2}, \mathrm{COO}^{-}\right\}$is részt vesznek a fémion kötésében. A ligandumfelesleg növelésével kialakul a $\mathrm{CdL}_{4}$ komplex, melyben újabb $\mathrm{Cys}$ tiolátcsoportok koordinációjával a korábbi $\left\{2 \times \mathrm{S}^{-}, \mathrm{NH}_{2}, \mathrm{COO}^{-}\right\}$típusú koordináció az amino-, és karboxilátcsoportok kiszorulásával fokozatosan alakul át $\left\{4 \times \mathrm{S}^{-}\right\}$típusú koordinációvá.

Ezzel ellentétben az N-terminálisan védett NAC $\mathrm{Cd}^{2+}$-komplexében kizárólag a tiolátcsoportok kötődnek a fémionhoz. Lúgos körülmények között a domináns $\mathrm{CdL}_{4}$ részecske kialakulásához 4-5× ligandumfelesleg is elegendő, azonban semleges $\mathrm{pH}$ tartományban $(\mathrm{pH}=7,5)$ 10-20× ligandumfelesleg szükséges komplex képződéséhez.

A PEN még nagy ligandumfelesleg hatására és lúgos körülmények mellett sem képes olyan komplexek kialakítására, amelyben négy tiolátcsoport koordinálódik a $\mathrm{Cd}^{2+}$-ionhoz. Helyette egy $\left\{3 \times \mathrm{S}^{-}, \mathrm{NH}_{2} / \mathrm{COO}^{-}\right\}$típusú koordinációs környezetet bizonyítottak. Ennek hátterében valószínűleg a penicillamin metilcsoportjainak (3.4.1.1. ábra) sztérikus gátlása állhat, ami miatt további ligandum kötődése nem kedvezményezett.

A Cys és NAC ligandumok $\mathrm{Hg}^{2+}$-ionokkal a fentiekhez hasonlóan akár $\left\{4 \times \mathrm{S}^{-}\right\}$ koordinációt is kialakíthatnak. (3.4.1.1. táblázat).

\begin{tabular}{cccc}
\hline $\mathbf{H}_{\mathbf{2}} \mathbf{C y s}: \mathbf{H g}^{\mathbf{2 +}}$ & \% $\mathbf{H g}(\mathbf{C y s})_{\mathbf{2}}$ & $\boldsymbol{\%} \mathbf{H g}(\mathbf{C y s})_{\mathbf{3}}$ & \% $\mathbf{H g}(\mathbf{C y s})_{\mathbf{4}}$ \\
\hline 2,2 & 94 & 6 & \\
3,3 & 42 & 58 & \\
4,3 & 12 & 62 & 26 \\
5,3 & 5 & 22 & 73 \\
10,1 & & $\sim 15$ & $\sim 85$
\end{tabular}

3.4.1.1. táblázat: A különböző összetételü részecskék megoszlása $\mathrm{pH}=11,0$-nál a fémion-ligandum arány változtatásának függvényében a $\mathrm{Cys}-\mathrm{Hg}^{2+}$ rendszerben [75]

PEN-nel végzett kísérletek során a közeg pH-jától függően két illetve három PEN egység kötődhet a $\mathrm{Hg}^{2+}$-ionhoz. A negyedik tiolátcsoport koordinálódása a fent említett sztérikus gátlás miatt még lúgos körülmények között sem kedvezményezett. A tiolátcsoportokon kívül más potenciális donorcsoport kötődését kizárták.

Egyensúlyi vizsgálatokkal két ekvivalens Cys jelenlétében meghatározták a már savas közegben is képződő $\mathrm{HgL}_{2}$ komplex stabilitását $\left(\lg \beta_{\mathrm{HgL}_{2}}=39,4\right)$ [79]. $\mathrm{Zn}^{2+}$-ionokkal is képződik $\mathrm{ZnL}_{2}$ összetételű részecske, stabilitása $\left(\lg \beta_{\mathrm{ZnL}_{2}}=18,05\right)$ azonban jelentősen elmarad a $\mathrm{Hg}^{2+}$-komplexétöl.

Cisztein felesleg mellett képződhetnek több olyan, különböző összetételü oligomer részecsk is ( $\mathrm{pl} .: \mathrm{Zn}_{3} \mathrm{HL}_{4}, \mathrm{Zn}_{2} \mathrm{~L}_{3}$ ), amelyek $\mathrm{pH}=6,0$ környékén domináns komplexek. Ezekben bizonyították, hogy a Cys aminosavak tiolátcsoportjai hídként kötik össze az egyes fémcentrumokat [80]. 
$\mathrm{Az} \mathrm{Ag}^{+}$-ionok Cys és Cys-tartalmú pepid-komplexeiröl kevés tudományos közleményt találhatunk. Ennek oka, hogy már erősen savas közegben $(\mathrm{pH}<3)$ is erös kölcsönhatást alakítanak ki a tiolátcsoportokkal, továbbá a vizsgálatukat megnehezíti a változatos szerkezetü és bonyolult összetételü klaszterek képződésének lehetősége.

Több kutatócsoport is vizsgálta a Cys és S-metilezett származékának $\mathrm{Ag}^{+}$-ionokkal alkotott komplexeit. Bizonyították, hogy a ligandumok már erősen savas körülmények között is kötődnek a fémionhoz, lineáris koordinációjú komplexeket képezve. A pH növelésével azonban az aminocsoportok is részt vesznek a fémion megkötésében, kialakítva a $\left\{2 \times \mathrm{S}^{-}, \mathrm{NH}_{2}\right\}$ típusú koordinációt $[81,82]$.

Leung és munkatársai ugyancsak vizsgálták a Cys, valamint PEN kölcsönhatását $\mathrm{Ag}^{+}$-ionokkal [83]. Az összeállított rendszerekben fokozatosan növelték a ligandum: $\mathrm{Ag}^{+}$ arányt $(2,0 \rightarrow 10,0)$, és meghatározták a képződő komplexek összetételét 10-es pH környékén. EXAFS mérések alapján az Ag-Cys komplexekben az Ag-S kötéstávolság 2,44 és 2,47 Å között változott, az $\mathrm{Ag}^{+}$-ionok átlagos koordinációs száma pedig 2,9-nek adódott. A kristályszerkezet, valamint az NMR vizsgálatok is alátámasztották, hogy az $\mathrm{AgL}_{3}$ komplexben a koordinációs mód $\left\{3 \times \mathrm{S}^{-}\right\}$illetve $\left\{2 \times \mathrm{S}^{-}, \mathrm{NH}_{2}\right\}$ típusú lehet, továbbá tioláthidas oligomerek képződését is tapasztalták. PEN jelenlétében igaz képződött kis mennyiségü $\mathrm{AgL}_{3}$ komplex is, azonban a már említett sztérikus gátlás miatt a $\left\{2 \times \mathrm{S}^{-}\right\}$típusú koordináció az uralkodó.

Egy másik közleményben is foglalkoztak Cys és PEN $\mathrm{Ag}^{+}$-kötő képességével [84]. Méréseik azt mutatták, hogy mind a Cys, mind a PEN pH $=7$ alatt 1:1 összetételü komplexeket képez az $\mathrm{Ag}^{+}$-ionnal. Magasabb pH-n azonban már nagyobb a megkötött fémionok aránya, emellett ESI-MS mérésekkel aggregátumok jelenlétét is bizonyítani tudták. A PEN komplexek szerkezete bonyolult, az $[\mathrm{R}-\mathrm{S}-\mathrm{Ag}]_{\mathrm{n}}$ láncok összefonódásával egy dupla hélix alakul ki, melyben a szomszédos $\mathrm{Ag}^{+}$-ionok közötti Van der Waals kölcsönhatások stabilizálják a szerkezetet.

\subsubsection{Egy ciszteint tartalmazó peptidek $d^{10}$ fémionokkal alkotott komplexei}

Cisztein és hisztidin tartalmú védett oligopeptideket vizsgált Nakamura munkatársaival [85]. A Cys-X-Y-His peptidek két $\mathrm{Hg}^{2+}$-iont is megköthetnek terminálisan a tiolát-, és az imidazol donorcsoportokkal, vagy a tiolát, mint hídligandum kapcsolhatja össze a két $\mathrm{Hg}^{2+}$-iont. Ez utóbbi komplexben a hisztidin imidazol-oldalláncának koordinációja is lehetséges valamelyik fémcentrumhoz (3.4.2.2. ábra). 


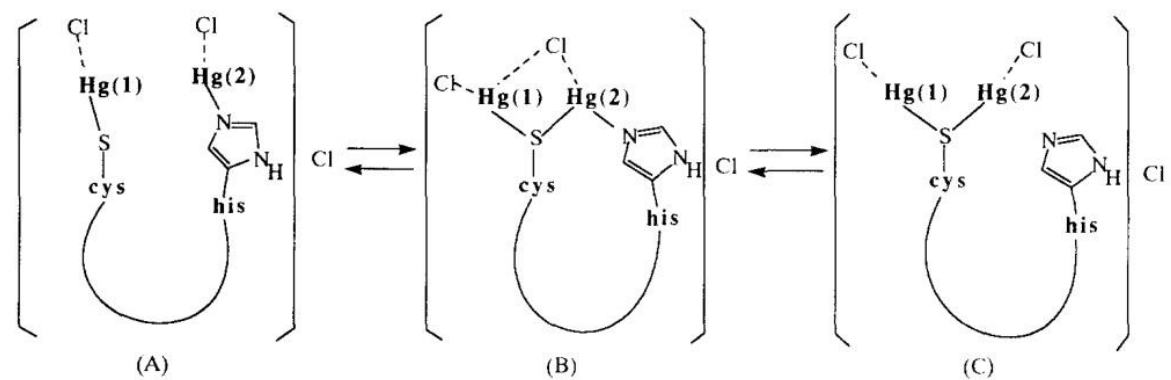

3.4.2.2. ábra: Javasolt $\mathrm{Hg}^{2+}$-kicserélődési folyamatok a Cys-X-Y-His komplexekben [85]

Több tanulmány is foglalkozik a kétértékü $\mathrm{d}^{10}$ átmenetifém-ionok GSH (glutation) komplexeivel. Bal és munkatársa oldatszerkezet-vizsgálatokkal bizonyították $\mathrm{Zn}^{2+}$-tartalmú mono-, és biszkomplexek létezését GSH felesleg alkalmazása mellett (3.4.2.3. ábra) [86].

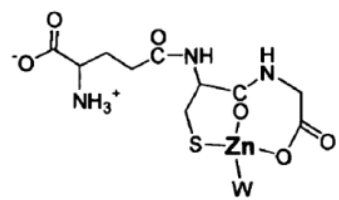

$\mathrm{ZnHL}$

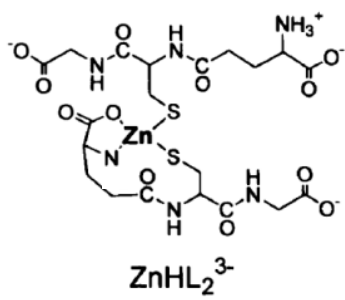

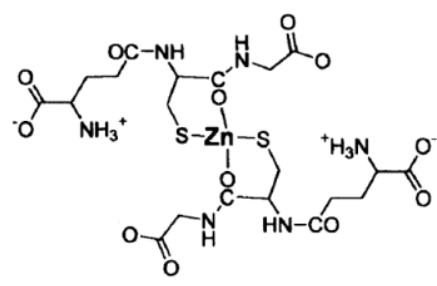

$\mathrm{ZnH}_{2} \mathrm{~L}_{2}^{2-}$

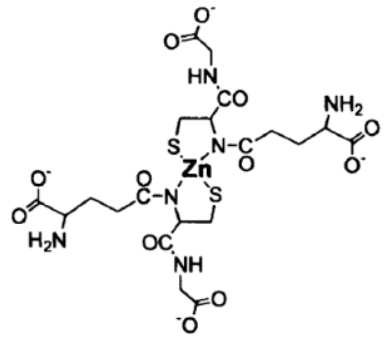

$\mathrm{ZnH}_{2} \mathrm{~L}_{2}{ }^{6-}$

3.4.2.3. ábra: $\mathrm{Zn}^{2+}-\mathrm{GSH}$ komplexek javasolt szerkezete [86]

A savas körülmények között kis mennyiségben képződő monokomplexekben (ZnHL $\lg \beta=14,74 ; \mathrm{ZnL} \lg \beta=8,31 ;[86])$ tiolátcsoport mellett a terminális karboxilátcsoport illetve vízmolekula is koordinálódhat a $\mathrm{Zn}^{2+}$-ionokhoz (3.4.2.3. ábra). $\mathrm{A} \mathrm{ZnH}_{2} \mathrm{~L}_{2}$ biszkomplexben a tiolátcsoportok koordinálódását karbonil-oxigének kötődése egészíti ki. A pH növelésével az oxigéntartalmú donorcsoportok fokozatosan szorulnak ki a koordinációs szférából $\left(\mathrm{ZnH}_{2} \mathrm{~L}_{2} \rightarrow \mathrm{ZnL}_{2} \rightarrow \mathrm{ZnH}_{-2} \mathrm{~L}_{2}\right)$, mellyel párhuzamosan az amidnitrogének koordinálódása figyelhető meg, ami meglehetősen ritka a $\mathrm{Zn}^{2+}$-peptid komplexekben.

Farideh és munkatársai szerkezetvizsgáló módszerekkel bizonyították, hogy 3-5× GSH felesleg mellett semleges $\mathrm{pH}$ környékén $\left\{3 \times \mathrm{S}^{-}, \mathrm{COO}^{-}\right\}$és $\left\{4 \times \mathrm{S}^{-}\right\}$típusú, tetraéderes geometriájú $\mathrm{CdL}_{4}$ komplexek keletkeznek [87]. Lúgos körülmények között 2-3 ekvivalens 
GSH-t alkalmazva három különböző szerkezetü részecskét azonosítottak. Egy $\left\{2 \times \mathrm{S}^{-}\right.$, $\left.2 \times \mathrm{NH}_{2}, 2 \times\left(\mathrm{NH}_{2} / \mathrm{COO}^{-} / \mathrm{OH}^{-}\right)\right\}$és egy $\left\{\mathrm{S}^{-}, 3 \times \mathrm{NH}_{2}, 2 \times\left(\mathrm{COO}^{-} / \mathrm{OH}^{-}\right)\right\}$típusú, egymással gyors cserében lévő komplex, melyekben a $\mathrm{Cd}^{2+}$-ionok koordinációjában hat donorcsoport vesz részt, valamint egy $\left\{4 \times \mathrm{S}^{-}\right\}$típusú $\mathrm{CdL}_{4}$ részecske. Nagy ligandumfelesleg alkalmazása mellett egyetlen domináns részecskét figyeltek meg $\left(\mathrm{CdL}_{4}\right)$, amelyben a fémionhoz kizárólag tiolátcsoportok kötődnek.

1996-ban Oram és munkatársai oldategyensúlyi vizsgálatokat végeztek $\mathrm{Hg}^{2+}$-ionokat és GSH-t tartalmazó rendszerekben [88]. Ekvivalens mennyiségü GSH mellett a HgL komplex stabilitása $\lg \beta=26,04-n e k$ adódott, míg ligandumfelesleg mellett képződő domináns részecske stabilitása $\left(\mathrm{HgL}_{2}, \lg \beta=33,40\right)$ a $\mathrm{Cd}^{2+}$ - és $\mathrm{Zn}^{2+}$-ionok GSH-val alkotott komplexeinek stabilitásához képest kiugróan magasnak bizonyult.

Semleges és lúgos körülmények között elegendően nagy ligandumfelesleg alkalmazásakor $\left\{4 \times \mathrm{S}^{-}\right\}$típusú $\mathrm{HgL}_{4}$ torzult tetraéderes geometriájú komplex dominál, azonban lineáris $\mathrm{HgL}_{2}$, illetve $\mathrm{HgL}_{3}$ trigonális komplexek képződése is lehetséges [89, 90].

Leung és munkatársai $\mathrm{Ag}^{+}$-ionok $\mathrm{GSH}$ komplexeinek vizsgálata során ligandumfelesleg alkalmazása mellett a kétértékü $\mathrm{d}^{10}$ fémionokkal ellentétben azt tapasztalták, hogy kizárólag $\left\{2 \times \mathrm{S}^{-}\right\}$típusú $\mathrm{AgL}_{2}$ részecskék vannak jelen a rendszerben [83].

\subsubsection{Több ciszteint tartalmazó peptidek $d^{10}$ fémionokkal alkotott komplexei}

A 3.1. fejezetben tárgyalt fitokelatinok és metallotioneinek müködésének megértése céljából több kutatócsoport is foglalkozott ezen molekulák, illetve analógjaik fémkomplexeivel.

2003-ban egy lengyel kutatócsoport vizsgálta a ( $\gamma$-Glu-Cys $)_{2}$ Gly PC2 fitokelatin $\mathrm{Cd}^{2+}$-komplexeit [91]. NMR, UV és egyensúlyi mérésekkel bizonyították, hogy a fémion: ligandum arányától függően mono-, és biszkomplexek is kialakulhatnak (3.4.3.1. ábra).

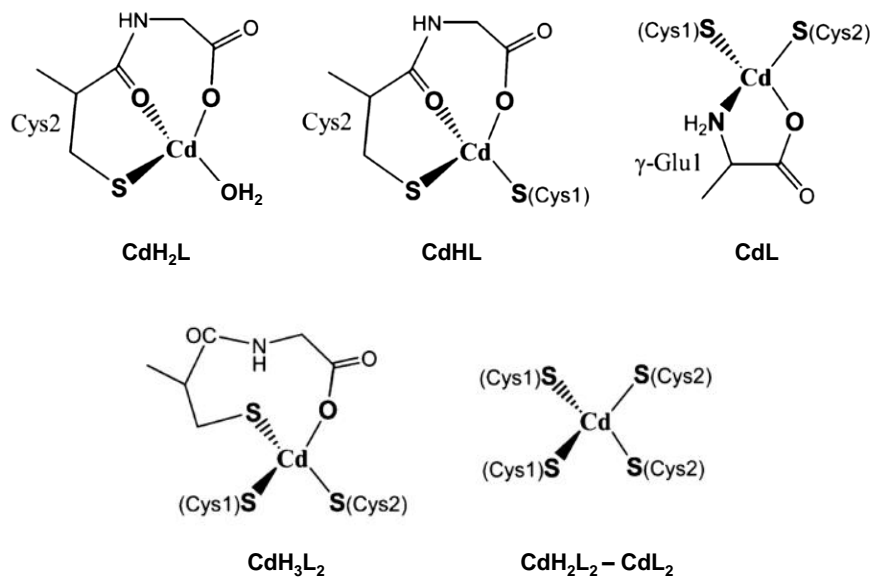

3.4.3.1. ábra: $\mathrm{Cd}^{2+}-\mathrm{PC} 2$ peptidkomplexek javasolt szerkezetei 
A monokomplexekben tiolátcsoportok mellett karbonil-, karboxil-, és aminocsoportok is kötődnek a fémionhoz. Ezzel szemben ligandumfelesleg hatására tiolátcsoportok kötődésével párhuzamosan az oxigén-, és nitrogéntartalmú donorcsoportok fokozatosan szorulnak ki a koordinációs szférából. A $\mathrm{CdL}_{2}$ részecskében a korábbiakkal ellentétben már $\left\{4 \times \mathrm{S}^{-}\right\}$típusú a koordináció.

Fiziológiás $\mathrm{pH}$ körül $(\mathrm{pH}=7,5)$ a $\mathrm{Zn}^{2+}$ - és $\mathrm{Cd}^{2+}$-ionok $\mathrm{PC} 2$ komplexeit összehasonlítva eltérő szerkezetű komplexek jelenlétét bizonyították [92]. $\mathrm{Zn}^{2+}$-ionok mellett a $\mathrm{Zn}^{2+}: \mathrm{PC} 2$ aránytól függetlenül kizárólag monokomplexek képződtek, amelyekben a tiolcsoportok mellett a peptidváz karbonil-, és Glu oldallánci karboxilát-csoportjai is részt vehetnek a koordinációban. Ezzel ellentétben $\mathrm{Cd}^{2+}$-ionok jelenlétében egy $\left\{2 \times \mathrm{S}^{-}, \mathrm{O}_{\mathrm{x}}, \mathrm{N}_{\mathrm{y}}\right.$, ahol $\mathrm{x}+\mathrm{y}=2$, és $\mathrm{x}=0$ vagy 1$\}$ típusú részecske mellett $\mathrm{Cd}^{2+}: \mathrm{PC} 2$ aránytól függően $\left\{4 \times \mathrm{S}^{-}\right\}$ típusú és többmagvú komplexek képződését is igazolták.

A ( $\gamma$-X-Cys $)_{7}$-Gly (ahol X = Glu, Asp, Lys, Gly, Ser, Gln aminosavakat jelölhet) természetes fitokelatinokkal analóg peptidszekvenciák $\mathrm{Cd}^{2+}$-komplexeit vizsgálta Satofuka és munkatársai [93]. Azt tapasztalták, hogy míg a $\gamma$-glutaminsavat $\alpha$ - glutaminsavra, vagy aszparaginsavra cserélték, a fémionhoz hasonló donorcsoportok koordinálódtak valamint a fémion affinitása hasonló a peptidhez, addig ezen aminosavakat oldallánci karboxilcsoportot nem tartalmazó aminosavra cserélve szignifikánsan kisebb stabilitású komplexek képződtek, melyből a karboxilcsoportok kitüntetett részvételére lehet következtetni.

A szintetikus ( $\alpha$-Glu-Cys) ${ }_{2}$ Gly molekula a natív fitokelatintól a glutaminsav $\gamma$ kapcsolódásában tér el [94]. Az így előállított ligandumok $\mathrm{Hg}^{2+}$-, és $\mathrm{Cd}^{2+}-\mathrm{komplexeit}$ vizsgálva a természetes $\gamma$-fitokelatinnal hasonló stabilitású komplexek képződését tapasztalták. $\mathrm{Cd}^{2+}$-ionokkal biszkomplexek, míg $\mathrm{Hg}^{2+}$-ionok esetén monokomplexek képződését bizonyították. $\mathrm{Hg}^{2+}$-ionok jelenlétében már erősen savas $(\mathrm{pH}<2)$ körülmények között lejátszódott a komplexképződés.

Metallotioneinekkel végzett kísérletek során megállapították, hogy a nyúl és patkány máj metallotioneinek $\mathrm{Hg}^{2+}$-komplexeinek összetétele és szerkezete $\mathrm{pH}$ és koncentrációfüggő [95]. Feltételezték, hogy $\mathrm{pH}=7$-nél a $\mathrm{Hg}_{7}-\mathrm{MT}$ összetételü komplexben a fémion körül tetraéderes geometriájú a koordinálódó csoportok elhelyezkedése, ami a $\mathrm{Hg}^{2+}$-ionok koncentrációjának növelésével fokozatosan alakul át $\mathrm{Hg}_{11}-\mathrm{MT}$ részecskévé, ahol már trigonális jellegü a koordinációs geometria.

Prolintartalmú metallotionein analógok vizsgálata során $\mathrm{Cd}^{2+}$-ionok jelenlétében $\mathrm{Cd}_{7-}$ MT összetételü komplex képződik, továbbá megállapították, hogy a $\mathrm{Zn}^{2+}$-komplexek 
hasonló stabilitásúak, mint a $\mathrm{Cd}^{2+}$-komplexek. A prolin megjelenését kísérő szerkezeti változás miatt a biológiai aktivitás is megváltozik [96].

Stillman kutatócsoportjában több évtizede folynak kutatások az emlősökben található metallotioneinek (MT) és fémionok kölcsönhatásának feltérképezése céljából [97]. Metallotioneinek $\mathrm{Ag}^{+}$-ionokkal alkotott komplexeiről bizonyították azok bonyolult klaszter jellegü szerkezetét. A CD spektroszkópiai vizsgálatok alapján $A_{n} M T$ részecskék kialakulását feltételezték és megállapították, hogy 17 ekvivalensnél több $\mathrm{Ag}^{+}$-ion már nem okoz további szerkezeti változást a ligandumon, az uralkodó részecske az $\mathrm{Ag}_{17} \mathrm{MT}$. Azonban a hömérséklet növelésének hatására egy $\mathrm{Ag}_{12} \mathrm{MT}$ forma is megjelent. $\mathrm{A} \mathrm{CD}$ spektrumok hasonlósága alapján a kétféle komplexben az $\mathrm{Ag}^{+}$-ion koordinációs geometriája hasonló.

Pecoraro és kutatócsoportja foglalkozik olyan oligopeptidek tervezésével és vizsgálatával, melyek háromszálú ún. „coiled coil” szerkezetet alakítanak ki [98]. Ezen TRI peptidcsaládba tagjai között találhatunk olyanokat is, melyekben a Cys egységek egymással szemben helyezkednek el az egyes szálakban. $\mathrm{A} \mathrm{d} \mathrm{d}^{10}$ fémiont is tartalmazó komplexekben $\left\{2 \times \mathrm{S}^{-}\right\}$lineáris, $\left\{3 \times \mathrm{S}^{-}, \mathrm{H}_{2} \mathrm{O}\right\}$ torzult trigonális piramis, $\left\{3 \times \mathrm{S}^{-}\right\}$síkháromszög, illetve négyes koordinációjú $\left\{4 \times \mathrm{S}^{-}\right\}$tetraéderes koordinációs geometria figyelhető meg.

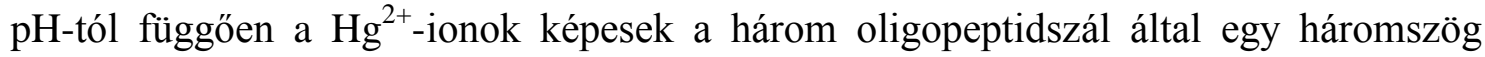
csúcspontjaiba rendezett tiolátcsoportok közül kettőhöz lineáris elrendeződésben $\left(\mathrm{HgL}_{2}\right)$, illetve háromhoz kapcsolódni síkháromszöges geometriában $\left(\mathrm{HgL}_{3}\right)$ [99] (3.4.3.2. ábra).

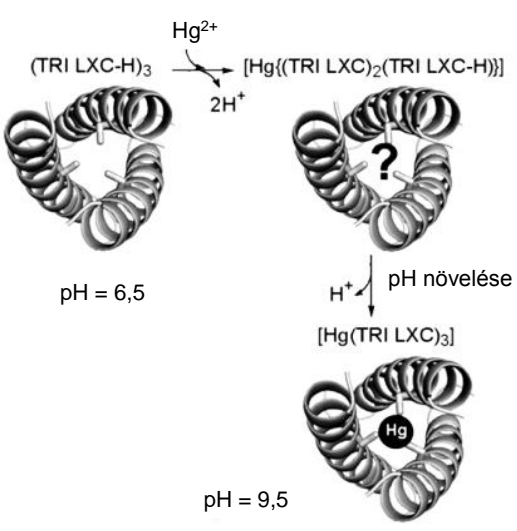

3.4.3.2. ábra: $\mathrm{A} \mathrm{Hg}^{2+}$-ion $\mathrm{pH}$-függő kötődése a TRI peptidcsalád egyik tagjához [99]

A TRI peptidcsalád módosított tagjainak (TRI L12C és TRI L16C) $\mathrm{Cd}^{2+}$-komplexeit vizsgálva kevert geometriájú és koordinációs módú fémcentrumokat figyeltek meg: egy $\left\{3 \times \mathrm{S}^{-}, \mathrm{H}_{2} \mathrm{O}\right\}$ koordinációval jellemezhető torzult trigonális piramisos komplexet, illetve egy $\left\{3 \times \mathrm{S}^{-}\right\}$összetételü síkháromszöges geometriájú részecskét. Az eredményeket PAC (Perturbed Angular Correlation) méréseken túl ${ }^{113} \mathrm{Cd}-\mathrm{NMR}$ spektroszkópiai mérésekkel is 
megerősítették [100]. A TRI L16C peptid $\mathrm{Zn}^{2+}{ }_{-k}$ komplexeinél hasonló összetételű és geometriájú komplexeket találtak [101].

A TRI peptidek módosításaival elöállíthatók olyan változatok is, ahol hélixenként több Cys alegység található két illetve három aminosav távolságra egymástól. $\mathrm{Hg}^{2+}-$, illetve $\mathrm{Cd}^{2+}$ ionok jelenlétében a két, illetve háromszálú rendszerek az adott fémionhoz kötődve a 3.4.3.3. ábrán bemutatott módon stabilizálhatók. A hat tiolcsoport lehetőséget teremt a torzult tetraéderes geometria mellett trigonális geometria kialakulására is két, illetve három hélix részvételével [102].

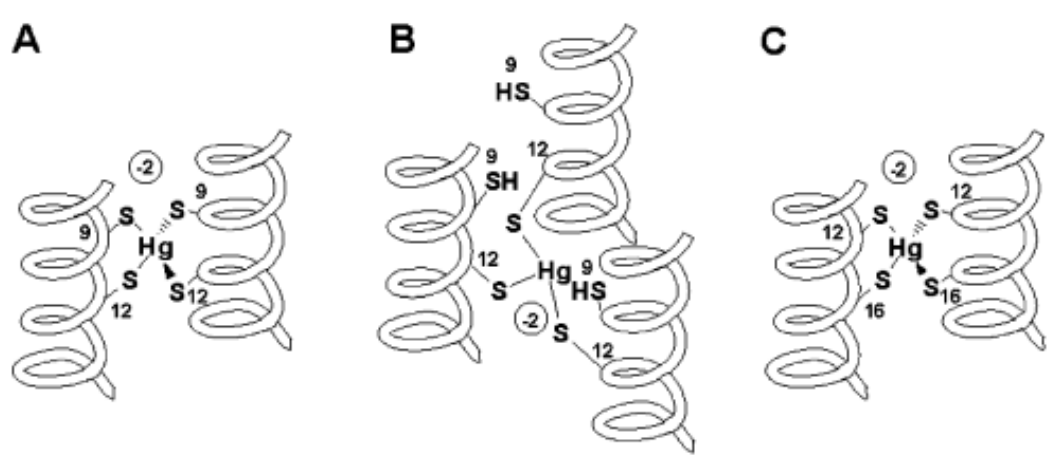

3.4.3.3. ábra: A két ciszteint tartalmazó TRI módosított peptidek $\mathrm{Hg}^{2+}$-komplexeinek javasolt szerkezete [102]

Hadjiliadis és kutatócsoportja N- és C-terminálisan védett ciszteint-, és az egyik ligandum esetén hisztidint is tartalmazó tetrapeptidek $\mathrm{Hg}^{2+}$-komplexeit tanulmányozta [103]. DMSO-ban többféle komplex kialakulását figyelték meg, melyekben, a ciszteinek tiolátcsoportjainak illetve a hisztidin imidazolcsoportjának koordinációját is kimutatták. A tiolát donorok terminális ligandumként vagy két fémcentrumot összekötő hídként is koordinálódhatnak a $\mathrm{Hg}^{2+}$-ionokhoz (3.4.2.1. ábra).
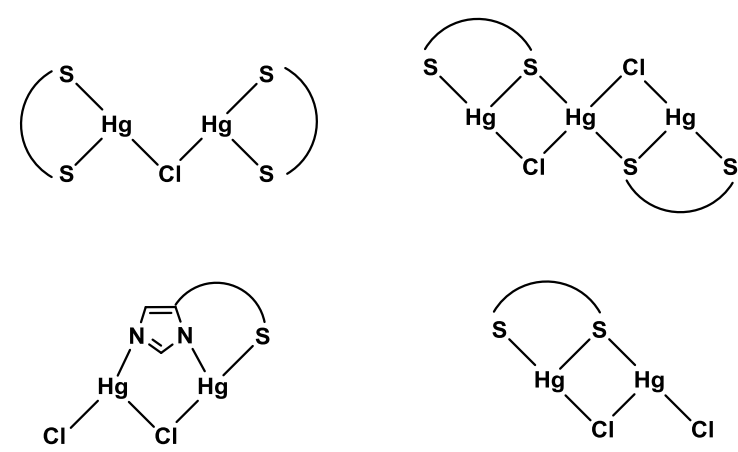

3.4.2.1. ábra: A DMSO-ban képződő $\mathrm{Hg}^{2+}$-komplexek javasolt szerkezete [102]

A d ${ }^{10}$ fémionok Cys-tartalmú tri/tetrapeptidekkel alkotott komplexeit vizsgálta Kulon és munkatársai [104]. Ezek a ligandumok kivétel nélkül tartalmazzák a -Cys-X-Cysmotívumot, amelyben az X egy tetszőleges aminosavat jelöl (Ac-CGC-NH ${ }_{2}$, Ac-CPCP$\mathrm{NH}_{2}$ ). A fémionok és a peptidek közötti kölcsönhatást $\mathrm{N}$-, és C-terminális is védett peptidek 
$\mathrm{Zn}^{2+}$-, és $\mathrm{Cd}^{2+}{ }_{-k}$ komplexeiben kizárólag a Cys tiolátcsoportjai koordinálódtak. Az uralkodó részecske minden esetben az $\mathrm{ML}_{2}$ komplex, amiben $\left\{4 \times \mathrm{S}^{-}\right\}$koordinációs módot feltételeztek, amit CD és MCD vizsgálatokkal is sikerült alátámasztani. Az N-terminálisan nem védett peptidek is 0,5:1 fémion:peptid sztöchiometriai arányban képeztek komplexeket a $\mathrm{Zn}^{2+}$ - és $\mathrm{Cd}^{2+}$-ionokkal, azonban a protonálódási állandók alapján ebben az esetben az aminocsoportok $\mathrm{N}$-atomjai is részt vesznek a fémionok megkötésében. A pH növelésével azonban a spektrumok nagy hasonlóságot mutattak az N-, és C-terminálisan is védett peptidek komplexeinek spektrumaival, ami $\left\{4 \times \mathrm{S}^{-}\right\}$koordinációs módra utal, melyet $\mathrm{CD}$ és MCD spektrumok szintén alátámasztottak.

N-terminálisan szabad, két Cys egységet tartalmazó hexa-, és heptapeptidek (CSSACS$\mathrm{NH}_{2}$ és ACSSACS- $\mathrm{NH}_{2}$ ) $\mathrm{Zn}^{2+}$-, és $\mathrm{Cd}^{2+}$-komplexeit vizsgálva Sóvágó és munkatársai szintén bizonyították, hogy a tiolátcsoportok mellett a terminális aminocsoport is részt vesz a fémion-koordinációban [105]. Lúgos körülmények között a hexapeptid esetében koordinálódó víz deprotonálódását heptapeptid fémkomplexeiben azonban fémion-indukálta amid-koordinációt tapasztaltak.

Gockel és munkatársai olyan His/Cys tartalmú tri-, és tetrapeptidek $\mathrm{Zn}^{2+}$-komplexeit vizsgálták, melyek N-, és C-terminálisan is védettek, így a donorcsoportok kizárólag a ciszteinek tiolcsoportjai, valamint a hisztidinek imidazolnitrogénjei lehetnek (3.4.3.4. ábra). Ezáltal a ligandumok ideális modelljei $\mathrm{Zn}^{2+}$-tartalmú metalloproteineknek [106].
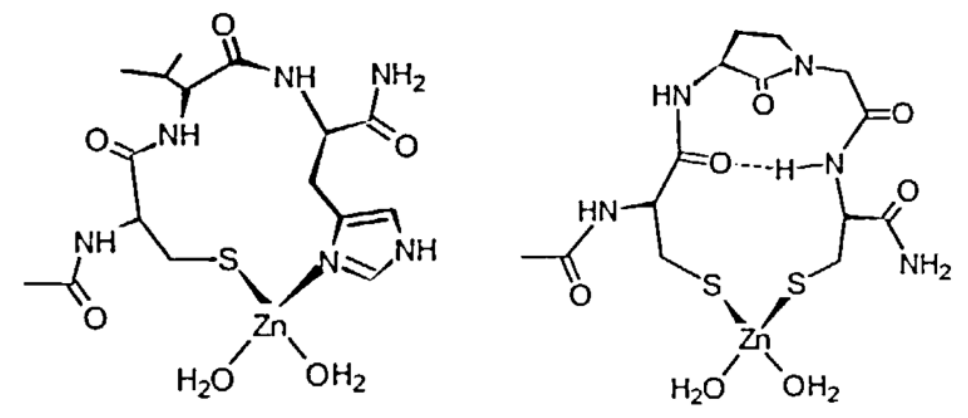

3.4.3.4. ábra: Gockel és munkatársai által előállított cisztein és hisztidin tartalmú, védett peptidek $\mathrm{Zn}^{2+}$-komplexei [106]

Oldategyensúlyi vizsgálatokkal bizonyították, hogy a 1:1 (fémion:ligandum) aránynál ZnL összetételü komplexek képződnek a potenciális donorcsoportok közötti távolságtól függően 12-17 tagszámú kelátgyürüt formálva. Továbbá igazolták a monokomplex dimerizációjával megjelenő $\mathrm{Zn}_{2} \mathrm{~L}_{2}$ részecske jelenlétét is.

A fenti kutatócsoport ugyancsak vizsgálta két Cys tartalmú di-, és tripeptidek elöállítását követően azok $\mathrm{Zn}^{2+}$-kötő sajátságait [107], valamint bizonyították a ZnL illetve $\mathrm{ZnL}_{2}$ összetételü komplex képződését is, $\left\{2 \times \mathrm{S}^{-}\right\}$illetve $\left\{4 \times \mathrm{S}^{-}\right\}$koordinációs móddal. 
Az N-, és C-terminálison egyaránt védett peptideket alkalmazva $Z_{2} \mathrm{~L}_{4}$ és $\mathrm{Zn}_{3} \mathrm{~L}_{4}$ komplexek jelenlétét tapasztalták, ami kezdődő aggregációra utal. A ZnL összetételü komplex stabilitása a ligandumok függvényében a következőképpen változott: ${ }_{\mathrm{L}} \mathrm{Cys}-\mathrm{L} \mathrm{Cys}<{ }_{\mathrm{L}} \mathrm{Cys}-\mathrm{X}-\mathrm{L} \mathrm{Cys}$, ami a Cys aminosavak egymáshoz viszonyított helyzetének fontosságát is mutatja.

A ciszteinek közötti távolságot növelve Kozlowski és munkatársai előállítottak olyan a kettő (Ac-GCASCDNARAAKK-NH ${ }_{2}$ ), három (Ac-GCASCDNCRAAKK-NH ${ }_{2}$ ), illetve négy (Ac-GCASCDNCRACKK-NH${ }_{2}$ ) ciszteint tartalmazó $\mathrm{N}$-, és C-terminálisan is védett peptideket, amelyekben a-Cys-X-X-Cys- motívum fellelhető [108]. A pH-potenciometriás, elektrongerjesztési és CD spektroszkópiai vizsgálatok során megállapították, hogy a ciszteinek számának növelésével a $\mathrm{Bi}^{3+}-, \mathrm{Cd}^{2+}$-, illetve $\mathrm{Zn}^{2+}$-komplexek stabilitása is nő. A fémion-peptidkomplexek stabilitását összehasonlítva a következő sorrendet állították fel: $\mathrm{Bi}^{3+}>>\mathrm{Cd}^{2+}>\mathrm{Zn}^{2+} . \mathrm{A} \mathrm{Bi}^{3+}$-komplexek képződése már savas $\mathrm{pH}$ tartományban $(\mathrm{pH}<3)$ is jelentős. A vizsgálatok továbbá bizonyították, hogy az Asp karboxilátcsoportjai, és a Lys عaminocsoportjai sem vesznek részt a koordinációban.

Szintén ez a kutatócsoport vizsgálta két, Gram negatív baktériumban található, $\mathrm{Ni}^{2+}$-ion homeosztázisában szerepet játszó fehérje (Hpn, HspA) peptidmodelljét. Mindkét fehérje Cterminális vége ciszteinben és hisztidinben is gazdag [109]. E szekvenciákat (-Cys-Cysmotívumot tartalmazó) N- és C-terminálisan védett formában állították elő. Míg az előzőekben bemutatott peptidekben a Cys egységek szeparáltan helyezkedtek el, itt szomszédos donorcsoportokról van szó, ami elősegítheti a két Cys közötti amidnitrogén koordinációját. Azonban a vizsgált rendszerekben a $\mathrm{Bi}^{3+}-, \mathrm{Cd}^{2+}-$, és $\mathrm{Zn}^{2+}$-komplexek stabilitása hasonló volt a korábban vizsgált peptidekéhez, melyből megállapítható, hogy amidnitrogén nem, Cys tiolcsoportok azonban részt vesznek a fémion-kötésben.

Kozlowski és munkatársai a ZIP13 $\mathrm{Zn}^{2+}$-iont szállító fehérje N-terminális doménjének (MPGCPCPGCG- $\mathrm{NH}_{2}$ ) komplexképző sajátságait is vizsgálták $\mathrm{Zn}^{2+}, \mathrm{Cd}^{2+}$, és $\mathrm{Bi}^{3+}$-ionok jelenlétében [110] (3.4.3.5. ábra).

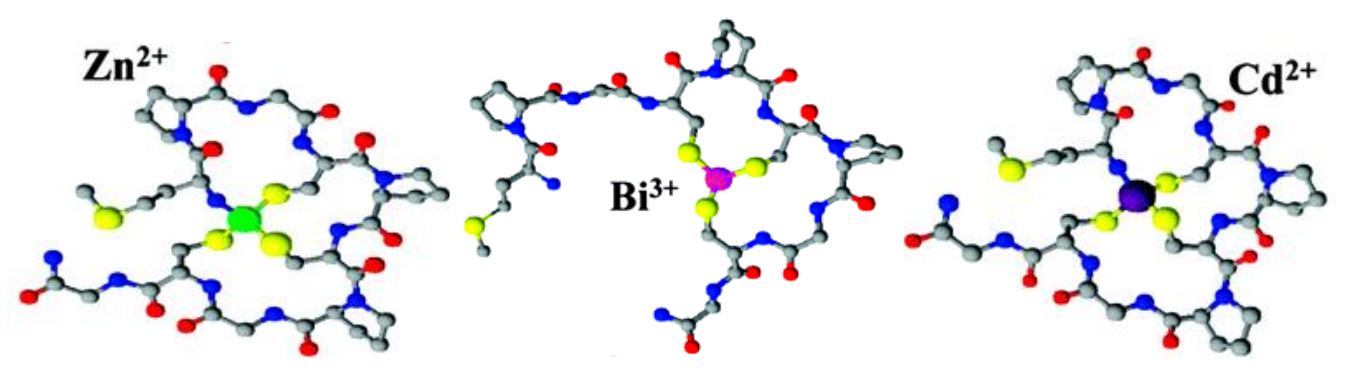

3.4.3.5. ábra: A -Cys-X-X-Cys-X-Cys- motívumot tartalmazó MPGCPCPGCG-NH $\mathrm{N}_{2}$ dekapeptid komplexeinek szerkezete [110] 
Savas körülmények között mindegyik vizsgált fémionnal egy MHL összetételü komplex képződik, melyben a koordináció a három cisztein tiolátcsoportjának részvételével valósul meg. Míg a $\mathrm{Zn}^{2+}$-, és $\mathrm{Cd}^{2+}$-komplexekben a $\mathrm{pH}$ növeléséve negyedik donorcsoportként a szabad N-terminális végen elhelyezkedő aminocsoport koordinációja feltételezhetőnek bizonyult, ezzel szemben $\mathrm{Bi}^{3+}$-ion esetén nem tapasztaltak változást. A komplexek több nagyságrendű stabilitás-növekedése (az előzőekben bemutatott mindkét terminálisán védett peptidek komplexeihez képest) az N-terminális szabad aminocsoport koordinációban való részvételével magyarázható. 


\section{Kísérleti és vizsgálati módszerek}

\section{Röviditések:}

$\begin{array}{ll}\text { Boc } & \text { - tercbutiloxi-karbonil } \\ \text { DIPEA: } & \text { - diizopropil-etilamin } \\ \text { Fmoc: } & \text { - fluorenil-metoxikarbonil } \\ \text { HBTU: } & \text { - O-benzotriazol-tetrametiluronium-hexafluorofoszfát } \\ \text { HOBt: } & \text { - 1-hidroxibenzotriazol } \\ \text { NMP: } & \text { - N-metil-pirrolidon } \\ \text { tBu: } & \text { - terc-butil } \\ \text { Trt: } & \text { - tritil (trifenil-metil) } \\ \text { TFA: } & \text { - trifluor-ecetsav } \\ \text { TIS: } & \text { - triizopropil-szilán } \\ \text { EDT: } & \text { - etán-ditiol } \\ \text { DCM: } & \text { - diklór-metán } \\ \text { MeOH: } & \text { - metanol } \\ \text { HS peptid, HS- Ac-SCHGDQGSDCSI-NH } & \\ \text { PS peptid, PS }- \text { Ac-SCPGDQGSDCSI-NH } & \\ \text { PP peptid, PP - Ac-SCPGDQGSDCPI-NH } & \\ \text { EC peptid, EC- Ac-ACPGDDSADCPI-NH } & \\ \text { Asp (D) } & \text { - Aszparaginsav } \\ \text { Cys (C) } & \text { - Cisztein } \\ \text { His (H) } & \text { - Hisztidin } \\ \text { Pro (P) } & \text { - Prolin } \\ \text { Ser (S) } & \text { - Szerin } \\ \text { Ala (A) } & \text { - Alanin } \\ \text { Gly (G) } & \text { - Glicin } \\ \text { Ile (I) } & \text { - Izoleucin } \\ \text { Gln (Q) } & \text { - Glutamin } \\ \end{array}$

\subsection{A ligandumok előállítása, szilárdfázisú peptidszintézis}

Munkám során négy $\mathrm{N}$ - és C-terminálisan is védett peptidet állítottunk elő Fmocstratégián alapuló szilárd-fázisú szintézissel. A dodekapeptidek előállításához Rink Amide AM gyantát (Novabiochem, borítottsága: $0,68 \mathrm{mmol} / \mathrm{g}$ ) használtunk, melyről bázisérzékeny Fmoc védőcsoporttal ellátott aminocsoport-kötőhelyek ágaztak le. „Építőkövekként” FmocSer(Trt)-OH, Fmoc-Ala-OH Fmoc-His(Trt)-OH, Fmoc-Asp(OtBu)-OH, Fmoc-Cys(Trt)$\mathrm{OH}$, Fmoc-Gly-OH, Fmoc-Ile-OH illetve Fmoc-Gln(Trt)-OH (Novabiochem) egységeket használtunk fel. Az aminosavak minden esetben szabad karboxilátcsoporttal kapcsolódtak a gyantához. Az Fmoc-védőcsoport eltávolítását piperidinnel (Alfa Aesar) (20\% (v/v) NMPben oldva (Molar)) végeztük. A kapcsolási lépések elősegítésére kapcsolószerként és 
aktivátorként HBTU és HOBt reagenseket (Novabiochem), bázisként pedig DIPEA-t használtunk (Sigma). A kapcsolások után szabadon maradó aminocsoportok acetilezéséhez $10 \%(\mathrm{v} / \mathrm{v})$ ecetsavanhidrid (Reanal) és $10 \%(\mathrm{v} / \mathrm{v})$ DIPEA DCM-es (Molar) oldatát alkalmaztuk. A szintézist egy szürővel ellátott 20 ml-es müanyag fecskendőben végeztük.

Mind a négy peptid szintéziséhez 1,0 g gyantát használtunk. A kapcsolási reakciók elött - az NMP-ben történő duzzasztást követően - az Fmoc csoportot a gyantáról $10 \mathrm{ml}$ $10 \%$-os $(\mathrm{v} / \mathrm{v})$ piperidin oldattal hasítottuk le $(2 \times 3$ perc, majd $1 \times 10$ perc $)$, majd a gyantát több kisebb részletben mostuk, összesen $20 \mathrm{ml}$ NMP-vel (4.1.1. ábra).

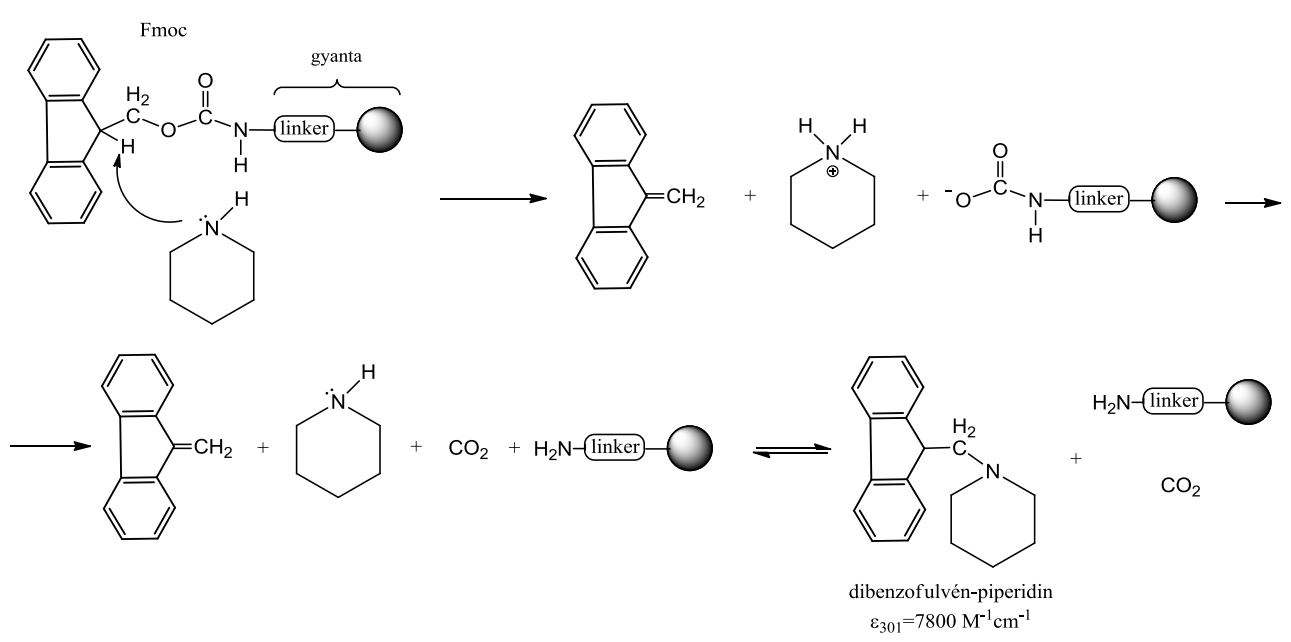

4.1.1. ábra: Az Fmoc védőcsoport eltávolítása során lejátszódó reakciók

A kapcsolandó aminosavak anyagmennyisége a gyanta gyárilag megadott kapacitás értékéből (mmol/g) számolható. Az aminosavakat a gyanta kapacitásához viszonyítva négyszeres feleslegben alkalmaztuk a nagyobb kitermelés érdekében. HBTU kapcsoló- és HOBt aktiváló reagensekből szintén négyszeres felesleget használtunk (4.1.2. ábra).

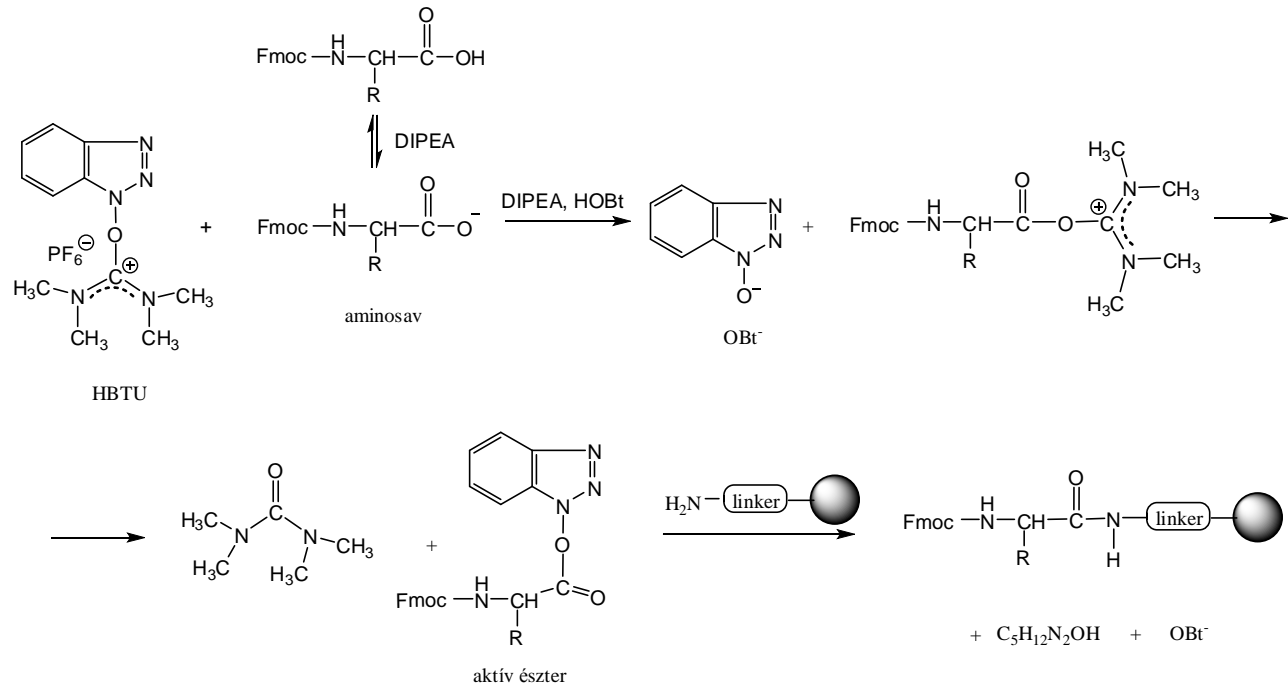

4.1.2. ábra: A kapcsolás során lejátszódó reakciók 
A kimért szilárd reagensekhez annyi NMP-t adtunk, míg az oldat ki nem tisztult. Ezt követően nyolcszoros feleslegben DIPEA bázist adtunk az oldathoz, majd homogenizáltuk. A korábban hasított, majd NMP-vel mosott gyantához hozzáadtuk az aktuális aminosav és a fentebb felsorolt segédanyagok NMP-s oldatát, majd forgatópadon $\sim 90$ percig forgattuk. A kapcsolást NMP-vel, DCM-mel és MeOH-val történő mosás, majd szárítás követte. A kapcsolási reakciók sikerességét Kaiser-teszt [111] segítségével ellenőriztük, amely a ninhidrin és a szabad aminocsoportok közötti színreakción alapul.

Mivel a szabályzó fehérje fémkötő régióját modelleztük, N- és C-terminálisan is védett peptidekre volt szükségünk. Ennek érdekében a szintézis utolsó lépéseként az Fmocvédőcsoport eltávolítása után a szabad aminocsoportokat acetileztük. A gyantát $10 \%(\mathrm{v} / \mathrm{v})$ ecetsavanhidridet (Reanal) és ugyancsak $10 \%$ (v/v) DIPEA-t tartalmazó DCM oldatban 15 percig állni hagytuk, majd a kezelést friss reagenssel megismételtük. A terméket TFA- $\mathrm{H}_{2} \mathrm{O}-$ EDT-TIS (gyökfogó) 94-2,5-2,5-1,0 \% (v/v) arányú elegyével hasítottuk le a szilárd hordozóról $(\sim 4 \mathrm{~h})$. A peptid savamid formában hasadt le a gyantáról, emellett a hasítóelegy a savérzékeny oldallánci védőcsoportokat (trt, Boc és tBu) is eltávolította.

A hasítás után a reakcióelegyet szürtük, majd a TFA-t és az EDT-t rotációs vákuumbepárlón ledesztilláltuk. A desztilláció során a hőmérsékletet a peptidek izomerizációjának elkerülése érdekében alacsony értéken (maximum 35-40 ${ }^{\circ} \mathrm{C}$ ) tartottuk. A desztilláció befejezésekor a lombikokban maradó kevés (3-4 ml) vizes, TFA tartalmú oldatot $40 \mathrm{ml}$ hütött dietil-éterhez csepegtettük, melynek hatására a peptid kicsapódott. Ezt követően a mintát 50 ml-es centrifugacsőben 5000 rpm-es fordulatszámon 30 percig centrifugáltuk, majd a dietil-étert a leülepedett csapadéktól elválasztottuk. Az ülepítési/felrázási lépéseket még 3× ismételtük a jól oldódó szerves szennyezők minél tökéletesebb eltávolítása érdekében. Ezután a szilárd, nyers peptideket 10-15 ml vízben oldottuk, majd fagyasztást követően liofilizáltuk. A termék azonosítása ESI-MS-sel, tisztítása pedig HPLC-vel történt (lásd a további fejezetekben).

\subsection{Folyadékkromatográfia}

A nyers peptideket fordított fázisú folyadékkromatográfia segítségével tisztítottuk, melyhez Shimadzu típusú HPLC készüléket és Supelco Discovery BIO Wide Pore C18 $(250 \times 10 \mathrm{~mm}, 5 \mu \mathrm{m})$ félpreparatív oszlopot használtunk. A peptidcsoportok fényelnyelését 215 nm-en, kétcsatornás UV detektorral követtük. A komponensek elválasztása állandó (izokratikus) mozgófázis összetétellel volt megvalósítható. 
HS: A eluens: $\mathrm{H}_{2} \mathrm{O}, 0,1 \%$ TFA; B eluens: $\mathrm{CH}_{3} \mathrm{CN}, 0,1 \%$ TFA.

Elúciós program: 0-55 perc $4 \% \mathrm{~B}$ (izokratikus); 0-55 perc 4\% C (izokratikus); 0-55 perc 46\% D (izokratikus). A frakciószedés időtartománya: 32,7-45,1 perc.

PS: A eluens: $\mathrm{H}_{2} \mathrm{O}, 0,2 \%$ TFA, B eluens: $\mathrm{CH}_{3} \mathrm{CN}, 0,2 \%$ TFA.

Elúciós program: 0-38 perc 0\% B (izokratikus); 38-42 0-25\% B (lineáris gradiens); 42-46 perc 25\% B (izokratikus); 46-47,5 perc 25-0\% B (lineáris gradiens); 47,5-50 perc 0\% B (izokratikus). A frakciószedés időtartománya: 30,8-35,1 perc.

PP: A eluens: $\mathrm{H}_{2} \mathrm{O}, 0,1 \%$ TFA, B eluens: $\mathrm{CH}_{3} \mathrm{CN}, 0,1 \%$ TFA.

Elúciós program: 0-41 perc 11,3\% B (izokratikus); $41-42$ perc 11,3-11\% B (lineáris gradiens); $42-46$ perc 11\% B (izokratikus); 46-47 perc 11-11,3\% B (lineáris gradiens);

47-50 perc 11,3\% B (izokratikus); 50-53 perc 11,3-30\% (lineáris gradiens); 53-59 perc 30\% B (lineáris gradiens); 59-61 perc 30-11,3 \% B (lineáris gradiens).

A frakciószedés időtartománya: 35,9-45,1 perc.

EC: A eluens: $\mathrm{H}_{2} \mathrm{O}, 0,1 \%$ TFA, B eluens: $\mathrm{CH}_{3} \mathrm{CN}, 0,1 \%$ TFA.

Elúciós program: 0-27 perc 15\% B (izokratikus); 27-35 perc 15-50\% B (lineáris gradiens); 35-42 perc 50\% B (izokratikus); $42-45$ perc 50-15\% B (lineáris gradiens); $45-50$ perc $15 \%$ B (izokratikus). A frakciószedés időtartománya: 18,7-22,6 perc.

\subsection{Tömegspektrometria (ESI-MS)}

A peptideket egy Finnigan TSQ-7000 tripla kvadrupol analizátoros, elektrospray ionizációs (ESI) ionforrással ellátott Finnigan-MAT, (San Jose, CA) tömegspektrométerrel azonosítottuk. A készülék tömegtartománya $10-2500 \mathrm{~m} / \mathrm{z}$, a kapilláris feszültség $4,5 \mathrm{kV}$, ködképző gázként $\mathrm{N}_{2}$-t használtunk. A nyers peptidek vizes oldatát, illetve a folyadékkromatográfiás tisztítás során gyüjtött frakciókat egy HPLC pumpa segítségével jutattuk a készülékbe (mozgófázis: metanol-víz-hangyasav = 49,9-50-0,1 térfogatarányban; HPLC pumpa: Applied Biosystems 140C; áramlási sebesség $250 \mu \mathrm{l} /$ perc; mintatérfogat: 5 $\mu \mathrm{l})$. A peptidek analitikai adatai:

- HS: $\mathrm{m} / \mathrm{z}=1249,64[\mathrm{M}+\mathrm{H}]^{+} ; \mathrm{m} / \mathrm{z}=625,09\left([\mathrm{M}+2 \mathrm{H}]^{2+}\right) / 2$. A számolt monoizotópos tömeg: $1248,45 \mathrm{~g} / \mathrm{mol}$.

- PS: $\mathrm{m} / \mathrm{z}=1207,44[\mathrm{M}-\mathrm{H}]^{-} ; \mathrm{m} / \mathrm{z}=603,21\left([\mathrm{M}-2 \mathrm{H}]^{2-}\right) / 2$. A számolt monoizotópos tömeg: $1208,44 \mathrm{~g} / \mathrm{mol}$. 
- PP: $\mathrm{m} / \mathrm{z}=1219,70[\mathrm{M}+\mathrm{H}]^{+} ; \mathrm{m} / \mathrm{z}=610,08\left([\mathrm{M}+2 \mathrm{H}]^{2+}\right) / 2$. A számolt monoizotópos tömeg: $1218,46 \mathrm{~g} / \mathrm{mol}$.

- $\quad$ EC: $\mathrm{m} / \mathrm{z}=1204,50[\mathrm{M}+\mathrm{H}]^{+} ; \mathrm{m} / \mathrm{z}=602,60\left([\mathrm{M}+2 \mathrm{H}]^{2+}\right) / 2$. A számolt monoizotópos tömeg: $1203,45 \mathrm{~g} / \mathrm{mol}$.

\subsection{A pH-potenciometria}

Az oldatbeli egyensúlyi vizsgálatok, a savi disszociációs $\left(K_{\mathrm{pqr}}\right)$ és komplexképződési $\left(\beta_{\mathrm{pqr}}\right)$ állandók meghatározása potenciometriás módszerrel történt. A módszert olyan folyamatok tanulmányozására lehet alkalmazni, ahol a fémionok leszorítják a ligandum protonjait, ami az oldatbeli hidrogénion-koncentráció megváltozásával jár, s így az üvegelektród által érzékelt potenciálváltozást eredményez. A pH-metriás titrálásokat vizes közegben, állandó hőmérsékleten $(298,0 \pm 0,1)$ és állandó ionerősség $\left(0,1 \mathrm{~mol} / \mathrm{dm}^{3}\right)$ mellett végeztük.

$\mathrm{Az}$ ionerősség beállítására minden esetben analitikai tisztaságú $\mathrm{NaClO}_{4}$-ot (Aldrich) használtunk. $\mathrm{A} \mathrm{CO}_{2}$ és $\mathrm{O}_{2}$ távoltartására oldatainkba és azok fölé inert gázt, nagy tisztaságú argont buborékoltattunk. A mérőoldat $\mathrm{NaOH}$ (Aldrich) 0,1 M koncentrációjú vizes oldata volt. A mérőoldat koncentrációját pontos beméréssel készített kálium-hidrogénftalát (Aldrich) oldat titrálásával határoztuk meg. A fémionok törzsoldatainak elkészítéséhez szilárd $\mathrm{Cd}\left(\mathrm{ClO}_{4}\right)_{2} \times \mathrm{H}_{2} \mathrm{O}$-ot, $\mathrm{Zn}\left(\mathrm{ClO}_{4}\right)_{2} \times \mathrm{H}_{2} \mathrm{O}$-ot, $\mathrm{Hg}\left(\mathrm{ClO}_{4}\right)_{2} \times \mathrm{H}_{2} \mathrm{O}$ és $\mathrm{AgClO}_{4} \times \mathrm{H}_{2} \mathrm{O}$-ot (Alfa Aesar) használtunk fel, majd oldataik pontos koncentrációit komplexometriás, illetve csapadékos titrálással határoztuk meg. A titrálásokat IBM-kompatibilis PC által vezérelt Dosimat 665 típusú Metrohm automata bürettából és Orion 710A precíziós pH-mérőből álló berendezéssel végeztük. Az Orion Ross kombinált üvegelektród (125 mm) kalibrálásához

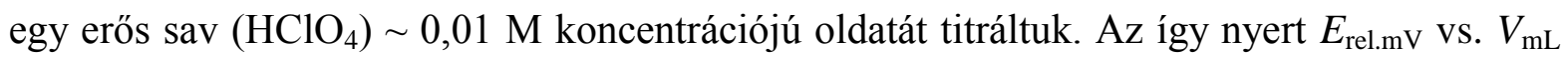
adatsorok értékelése a módosított Nernst-egyenlet alapján történt [112]:

$$
E=E_{0}+K \cdot \log \left[\mathrm{H}^{+}\right]+J_{\mathrm{H}} \cdot\left[\mathrm{H}^{+}\right]+\frac{J_{\mathrm{OH}} \cdot K_{\mathrm{w}}}{\left[\mathrm{H}^{+}\right]}
$$

melyben az ismert paraméterek mellett $J_{\mathrm{H}}$ és $J_{\mathrm{OH}}$ az üvegelektród savas, illetve lúgos hibájának, valamint a folyadék-folyadék határfelületi potenciálból adódó hibáknak a korrekciójára szolgáló illesztési paraméterek, a $K_{\mathrm{W}}=10^{-13,75}$ pedig a víz autoprotolízisállandója [113]. A paraméterek kiszámítása a nemlineáris legkisebb négyzetek módszere 
szerint történt. A rendszerekben képződő részecskék az alábbi általános egyensúlyi folyamattal, ill. képződési állandóval jellemezhetőek:

$$
\begin{gathered}
\mathrm{pM}^{2+}+\mathrm{qH}^{+}+\mathrm{rL}^{x-} \stackrel{\beta_{\mathrm{pqr}}}{\rightleftharpoons} \mathrm{M}_{\mathrm{p}} \mathrm{H}_{\mathrm{q}} \mathrm{L}_{\mathrm{r}}^{(2 \mathrm{p}+\mathrm{q}-\mathrm{x})^{+}} \\
\beta_{p q r}=\frac{\left[M_{p} H_{q} L_{r}\right]}{[M]^{p}[H]^{q}[L]^{r}}
\end{gathered}
$$

ahol M a fémiont, L a nemprotonált ligandum molekulát jelöli. Az utóbbi egyenletben, és a továbbiakban mindenhol, a töltések jelölésétől az egyszerüség kedvéért eltekintünk, azonban ezek minden egyes részecskére könnyen kiszámíthatók, ha figyelembe vesszük, hogy a teljesen protonált ligandum a HS peptid esetén $\mathrm{H}_{5} \mathrm{~L}^{+}$, az EC peptidnél $\mathrm{H}_{5} \mathrm{~L}$, a PS és PP peptidnél pedig $\mathrm{H}_{4} \mathrm{~L}$ képlettel írható le.

A ligandumok protonálódási állandóit 3-4 párhuzamos titrálásból határoztuk meg, míg a fémiont is tartalmazó rendszerekben 8-9 mérést végeztünk $\mathrm{pH}=2-11$ tartományban. Adatsoraink 70-90 adatpontot tartalmaztak. A titrálási görbék kiértékelése során a protonálódási és komplexképződési állandókat a PSEQUAD nevű számítógépes programmal határoztuk meg [114]. A ligandum koncentrációja egy tipikus mintában $\sim 1,0 \times 10^{-3} \mathrm{M}$ volt.

A vizsgált peptidek $\mathrm{Hg}^{2+}$-ionokkal kialakított rendkívül erős kölcsönhatása miatt a $\mathrm{pH}$ potenciometriás módszert csak a ligandum protonálódási folyamatainak vizsgálatára tudtuk alkalmazni. A látszólagos stabilitási állandó meghatározásához ligandum-kiszorításos módszert használtunk (lásd 5.3.1. fejezet).

\subsection{UV-látható spektroszkópia}

Peptidekben az UV-Vis spektroszkópiában jellemző átmenetek a $\pi \rightarrow \pi^{*}, \mathrm{n} \rightarrow \pi$ illetve $\mathrm{n} \rightarrow \sigma^{*}$. Az első az egyszerü telítetlen vagy aromás rendszerekre (peptidekben például a fenilalanin, a tirozin és a triptofán aromás gyürüi), a második a heteroatomot tartalmazó telítetlen vagy aromás rendszerekre (peptidekben például a hisztidin nitrogént tartalmazó aromás gyürüje), a harmadik pedig a csak $\sigma$ kötésekből álló csoportokhoz kapcsolódó nemkötő elektronpárral rendelkező heteroatomokat tartalmazó rendszerekre jellemző (pl. a szerin oxigénje, cisztein kene).

Mivel kísérleteinket $\mathrm{d}^{10}$ fémionokkal végeztük d-d abszorpciós sávok vizsgálatára nem volt lehetőségünk. Viszont az elektronátmenetek másik osztálya, a töltésátviteli (CT) sávok vizsgálata is fontos lehet a komplexek szerkezetének felderítésében. 
Míg az előző esetben az elektronátmenet a fémes pályákon való átrendeződés eredménye, addig a töltésátviteli sávok elektron donor - elektron akceptor átmenetekkel jellemezhetőek (pl.: $\mathrm{S}_{\text {tiolát }}^{-} \rightarrow \mathrm{M}^{+/ 2+}$ ). Ezen átmenetek eredményeként egyedi, nagy intenzitású (akár ezerszer nagyobb $\varepsilon$, mint a d-d átmeneteknél) abszorpciós sávok jelenhetnek meg az UV/látható tartományban.

Az UV-Vis mérések Dániában, a Koppenhágai Egyetemen egy Shimadzu UV3600 UV-VIS-NIR típusú, kétutas spektrofotométeren, valamint Szegeden egy Unicam Helios $\alpha$ típusú, kétutas spektrofotométeren, teflondugós szükített kvarcküvettában $(1=10 \mathrm{~mm})$, $\lambda=200-400 \mathrm{~nm}$ hullámhossz-tartományban történtek. Az UV-titrálásokat vizes közegben, állandó hőmérsékleten $\left(25^{\circ} \mathrm{C}\right)$ végeztük. Az inert atmoszféra biztosítása érdekében a mintákat argon atmoszféra alatt készítettük. Az egyes titrálások során a fémion:ligandum arányt változtattuk 0:1-től 2:1-ig. A mérések során a ligandumok koncentrációja minden esetben $1,0 \times 10^{-4} \mathrm{M}$ volt.

\subsection{CD-spektroszkópia}

A síkban poláros fény felbontható egy jobbra és egy balra forgató komponensre. A fehérjék és peptidek, mint optikailag aktív anyagok, egy adott hullámhossz-tartományban a jobbra és balra forgató cirkulárisan poláros fényt eltérő mértékben nyelik el. Ezt a jelenséget nevezik cirkuláris dikroizmusnak vagy felfedezőjéről Cotton-effektusnak.

A CD spektrum rögzítésekor a jobbra és balra forgó fény komponensek abszorpciójának különbségét mérjük a besugárzó fény hullámhosszának függvényében. A müszerek többsége viszont ezt átalakítja ellipticitás vs. hullámhossz görbévé. Az ellipticitás egyenlő az elliptikusan poláris fény kis- és nagytengelye hányadosának arcustangensével, az egységnyi koncentrációra jellemző mennyiség pedig a moláris ellipticitás. A CD spektrumokban negatív előjelü sávok is előfordulhatnak, valamint eltérően az UV-Vis abszorpciós spektroszkópiától a sávok jóval keskenyebbek. A CD spektroszkópia hatékony peptidek és komplexeik vizsgálatában a szabad és komplexben levő peptid konformációjának eltérő volta miatt.

A polipeptidek/fehérjék szerkezet-vizsgálatában főként a $C D$ spektrum ultraibolya tartománya informatív. Az amidkromofórok elnyelési hullámhossz-tartományában (180250nm) ezen csoportok egymáshoz képesti elrendeződése, tehát az egyes másodlagos szerkezeti elemekre jellemző spektrumok mérhetők. 
Míg a fehérjék CD spektrumaiban gyakran stabilis helikális vagy $\beta$-redőzött szerkezetek figyelhetők meg, addig ez a rövid peptidek esetében ritkaságszámba megy (bár léteznek olyan peptidek, melyek preferáltan egyféle szerkezetet alakítanak ki). A rövid peptidek (mint amilyenek az általunk vizsgált 12 aminosavból álló, bakteriális CueR fehérje fémkötő-helyét modellező peptidek is) általában nem képesek egy adott stabilis másodlagos szerkezet kialakítására. Bár létrejöhetnek intramolekuláris hidrogénkötések, illetve elektrosztatikus, hidrofób és sztérikus hatások is előnyben részesíthetnek adott konformációt, de a sokkal kiterjedtebb, oldószerrel kialakított kölcsönhatás nagyobb flexibilitást biztosít a molekulának. Ezért a CD spektrumban legtöbbször nem figyelhető meg állandó rendezett szerkezet. A CD spektrumok alakja egy adott konformációs (szerkezet) eloszlásra jellemző. Ennek az az oka, hogy az ideiglenesen kialakuló helikális vagy $\beta$-redőzött struktúrák lassan alakulnak át a CD spektroszkópia időskálájához mérten, ami miatt az összes lehetséges másodlagos szerkezethez tartozó spektrum súlyozott összegét figyelhetjük meg. A kis peptidek CD spektruma az esetek többségében a véletlenszerü/rendezetlen/egyéb konformációként meghatározott fehérje spektrumhoz hasonló. A CD spektrumok változó körülmények között történő felvételével (különböző $\mathrm{pH}$, ionerősség, hőmérséklet, fémionok és egyéb kölcsönható partnerek jelen, illetve távollétében) megfigyelhető, hogy az adott konformációs populáció hogyan változik meg. Összességében továbbra is folyamatosan egymásba alakuló szerkezetekről beszélünk, azonban más lesz a különböző szerkezetek eloszlása.

Spektrumaink egy részét a dániai Institute for Storage Ring Facilities, University of Aarhus (ASTRID-ISA) CD készülékén lettek felvéve. A részecskegyorsítóból a lineárisan polarizált fény egy $\mathrm{CaF}_{2}$ ablakon halad keresztül a $\mathrm{CD}$ készülékbe, folyamatos $\mathrm{N}_{2}$ áram mellett, ahol a fotoelasztikus modulátor a polarizált fényt felváltva jobbra, illetve balra cirkulárisan polarizált fénysugárrá átalakítja. A CD jelek rögzítése a modulátorral szinkronizált fotoelektron-sokszorozó detektor segítségével történt. A készülék kalibrálása kámforszulfonsav spektruma alapján történt. A spektrumokat a 170-330 nm tartományban, $\sim 1,0 \times 10^{-3} \mathrm{M}$ oldatokban rögzítettük $1 \mathrm{~nm}$-es lépésenként, 0,1 mm-es kvarc cellában (SUPRASIL, Hellma GmbH, Germany). A méréseket témavezetőim végezték, én a spektrumok kiértékelése során kapcsolódtam be a munkába. CD mérések készültek a Koppenhágai Egyetemen egy Jasco J-815 CD készüléken (JASCO, Essex) is. A spektrumokat 180-260 nm tartományban, $1 \times 10^{-4} \mathrm{M}$ ligandumkoncentráció mellett mértük 1 nm-es lépésenként, 1 mm-es kvarc cellában. 


\subsection{NMR-spektroszkópia}

A mágneses magrezonancia spektroszkópia szintén a ligandum szerkezetéről, illetve a fémion ligandumra gyakorolt hatásáról nyújt információt. $\mathrm{Az}{ }^{1} \mathrm{H}$ NMR segítségével a fémiont tartalmazó rendszerek vizsgálataiban az egyes atomcsoportokra jellemző jelek kiszélesedéséből és kémiai eltolódás értékéből, valamint a jelek felhasadásából következtethetünk a ligandum különböző csoportjainak protonáltságára, illetve fémionkoordinációjára.

Amíg a szabad ligandum titrálásához és fémion jelenlétében végzett mérésekhez egydimenziós NMR módszert alkalmaztunk, az egyes rezonanciák hidrogénekhez történő pontos hozzárendelését, valamint az azonos aminosavak protonjaihoz tartozó jelek sorbafejtését kétdimenziós módszerrel végeztük.

A kétdimenziós módszer alapja, hogy ha a mintát egy rövid rádiófrekvenciás impulzusnak tesszük ki, akkor valamennyi magot egyszerre tudjuk gerjeszteni. A sugárzást megszüntetve a mágnesezettség y irányú komponensének időbeli csökkenését tudjuk mérni. Ha az impulzus után skaláris csatolás, kémiai csere vagy dipoláris csatolás modulálja a jelet, akkor egy újabb impulzus alkalmazásával kétdimenziós spektrumok felvételére nyílik lehetőség. Ezeket a spektrumokat felülnézetből ábrázolják, így a csatoló magok helyét keresztcsúcsok jelzik. Ez a korrelációs spektroszkópia (COSY), mely az egymással geminális vagy vicinális csatolásban lévő protonokról ad információt. Abban az esetben, ha az első impulzust úgynevezett spin lock követi, a mágnesezettség az x - y síkban marad, így egy spinrendszeren belül akár 5-6 kötésen keresztül is tovább terjedhet. Ennek köszönhetően olyan skaláris csatolásokhoz rendelhető keresztcsúcsok is megjelennek, melyeket a COSY spektrumokon nem láthatunk. Ezt a módszert totál korrelációs spektroszkópiának nevezzük (TOCSY). Hosszabb, ám gyengébb spin lock alkalmazásával olyan protonok csatolását tudjuk meghatározni, melyek térbeli közelségük révén lépnek egymással kölcsönhatásba. $\mathrm{Az}$ így kapott ROESY spektrumok segítségével tanulmányozhatjuk a téren át ható csatolásokat az egymáshoz közel elhelyezkedő hidrogének között, ami lehetőséget teremt arra is, hogy egy peptid aminosav-sorrendjét megállapítsuk.

Az NMR spektrumokat Koppenhágában egy Bruker Avance DRX 500-as, illetve egy Bruker Avance DRX 600-as spektrométereken, valamint Szegeden egy Bruker Avance DRX 500-as készüléken vettük fel (müködési frekvencia: 500,13 MHz, illetve 600,11 MHz). A minták készítéséhez oldószerként $10 \% \quad \mathrm{D}_{2} \mathrm{O}-\mathrm{t}$ (Aldrich) tartalmazó desztillált vizet használtunk. Az oldatok pH-ját 0,1 és 0,01 M-os $\mathrm{NaOH}$ oldatokkal állítottuk be. 
A kémiai eltolódás értékeket $(\delta)$ TSP (trimetilszilil-propionát) belső referens alkalmazásával határoztuk meg. A ligandum koncentrációja egy tipikus mintában 1,0$1,3 \times 10^{-3} \mathrm{M}$ volt. A felvett 2D COSY, TOCSY és ROESY spektrumok 2048(F2) $\times 1024(\mathrm{~F} 1)$ komplex pontot tartalmaztak. A mérések kiértékeléséhez az ACD/NMR Processor Academic Edition valamint Bruker TopSpin 3.2 programokat használtunk.

\subsection{Perturbált gamma-gamma szögkorrelációs spektroszkópia (PAC)}

A perturbált gamma-gamma szögkorrelációs spektroszkópia (PAC) olyan spektroszkópiai módszerek közé tartozik, amelyek a hiperfinom kölcsönhatásokat vizsgálják, mint például az NMR, az EPR (elektron paramágneses rezonancia) vagy az NQR (mag kvadrupol rezonancia). A szervetlen és bioszervetlen kémiában a PAC spektroszkópia információval szolgálhat a lokális elektron- és molekulaszerkezetről, valamint az adott PAC érzékeny magot körülvevő molekula dinamikai sajátságairól. Ez a technika tehát kiválóan alkalmazható olyan fémiont tartalmazó rendszerek vizsgálatára (pl. metalloproteinek és modelljeik), amelyben az adott fémion egy a PAC spektroszkópia módszeréhez megfelelő izotóppal helyettesíthető (4.8.1. táblázat). Az ilyen izotópok legfontosabb tulajdonsága, hogy bomlásuk közben két gamma részecskét bocsátanak ki.

\begin{tabular}{lllccccc}
\hline $\begin{array}{c}\text { Szülö } \\
\text { elem }\end{array}$ & Felezési idő & Bomlás & $\begin{array}{c}\text { Leány } \\
\text { elem }\end{array}$ & $\begin{array}{c}\text { Átmeneti állapot } \\
\text { felezési ideje (ns) }\end{array}$ & $\begin{array}{c}\text { Spin } \\
\text { állapot }\end{array}$ & $\begin{array}{c}\mathbf{E}\left(\gamma_{1}\right) \\
\mathbf{k e V}\end{array}$ & $\begin{array}{c}\mathbf{E}\left(\gamma_{2}\right) \\
\text { keV }\end{array}$ \\
\hline${ }^{44} \mathrm{Ti}$ & 47 év & $\mathrm{EC}$ & ${ }^{44} \mathrm{Sc}$ & 153,0 & 1 & 78 & 68 \\
${ }^{57} \mathrm{Co}$ & 271 nap & $\mathrm{EC}$ & ${ }^{57} \mathrm{Fe}$ & 98,5 & $3 / 2$ & 122 & 14,4 \\
${ }^{99} \mathrm{Mo}$ & 66 óra & $\beta^{-}$ & ${ }^{99} \mathrm{Tc}$ & 3,61 & $5 / 2$ & 740 & 181 \\
${ }^{111 \mathrm{~m}} \mathrm{Cd}$ & 49 perc & $\mathrm{IT}$ & ${ }^{111} \mathrm{Cd}$ & 85,1 & $5 / 2$ & 151 & 245 \\
${ }^{133} \mathrm{Ba}$ & 11 év & $\mathrm{EC}$ & ${ }^{133} \mathrm{Cs}$ & 6,27 & $5 / 2$ & 356 & 81 \\
${ }^{187} \mathrm{~W}$ & 23,9 óra & $\beta^{-}$ & ${ }^{188} \mathrm{Re}$ & 555,0 & $9 / 2$ & 479 & 72 \\
${ }^{199 m} \mathrm{Hg}$ & 42,6 perc & $\mathrm{IT}$ & ${ }^{199} \mathrm{Hg}$ & 2,45 & $5 / 2$ & 374 & 158 \\
\hline
\end{tabular}

4.8.1. táblázat: Néhány PAC izotóp adatai

Egy ilyen bomlási kaszkádban az első $\gamma$-fotont egy adott irányban lehet detektálni, de a második foton az elsőhöz képest anizotróp módon, meghatározott irányban fog távozni az ún. szögmomentum megmaradásának elve miatt (4.8.1. ábra) [115]. Ebből az ún. szögkorrelációból ered a PAC mozaikszó is. 


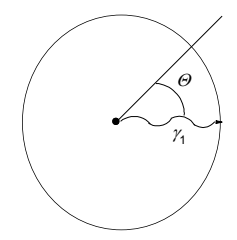

4.8.1. ábra: A $\gamma_{1}$ és $\gamma_{2}$ fotonok közötti szögkorreláció; a centrum és a körvonal közötti távolság arányos a $\gamma_{2}$ foton adott szög $(\Theta)$ alatti detektálásával, $\gamma_{1}$ fotonhoz képest

A külső elektromos térben elhelyezkedő kvadrupol mag pozitív magtöltés-eloszlása és az őt körülvevő töltéseloszlás közötti kölcsönhatás (NQI) különböző energiájú elrendeződéseket eredményez (4.8.2. ábrán bal).
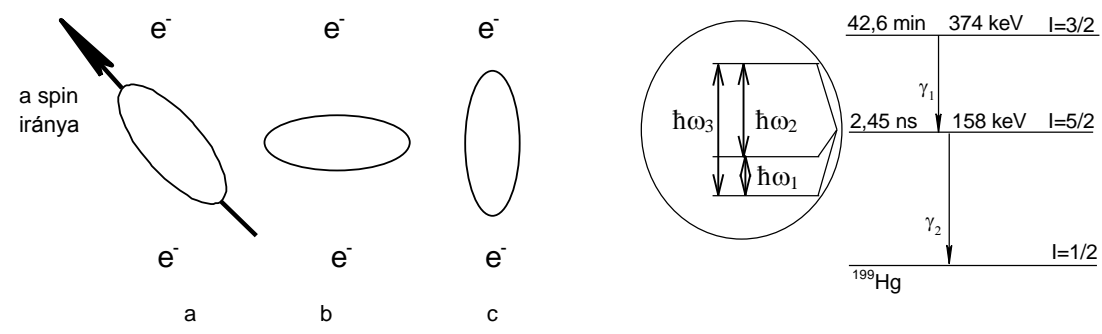

4.8.2. ábra: Bal oldalon: egy atommag külső elektromos térben, két negatív ponttöltés között: a legnagyobb energiájú (c), a legkisebb (b) és egy köztes energiájú állapot (a); jobbra: a ${ }^{199 \mathrm{~m}} \mathrm{Hg}$ izotóp bomlási sémája és a köztes energiaállapot hiperfinom felhasadása

Ez a kölcsönhatás a ${ }^{199 m} \mathrm{Hg}$ izotóp két, egymást követő $\gamma$-foton kibocsátásával járó bomlása során az átmeneti állapot hiperfinom felhasadását eredményezi, amely kinagyítva látható a 4.8.2. ábra jobb oldalán. Ez az atommag és az azt körülvevő elektromos tér közötti hiperfinom kölcsönhatás ujjlenyomatszerüen jellemzi az adott izotópot. Ez alapján a koordináció geometriai viszonyaira és a koordinációban részt vevő csoportok számára, valamint tulajdonságaira következtethetünk a PAC spektrumokból.

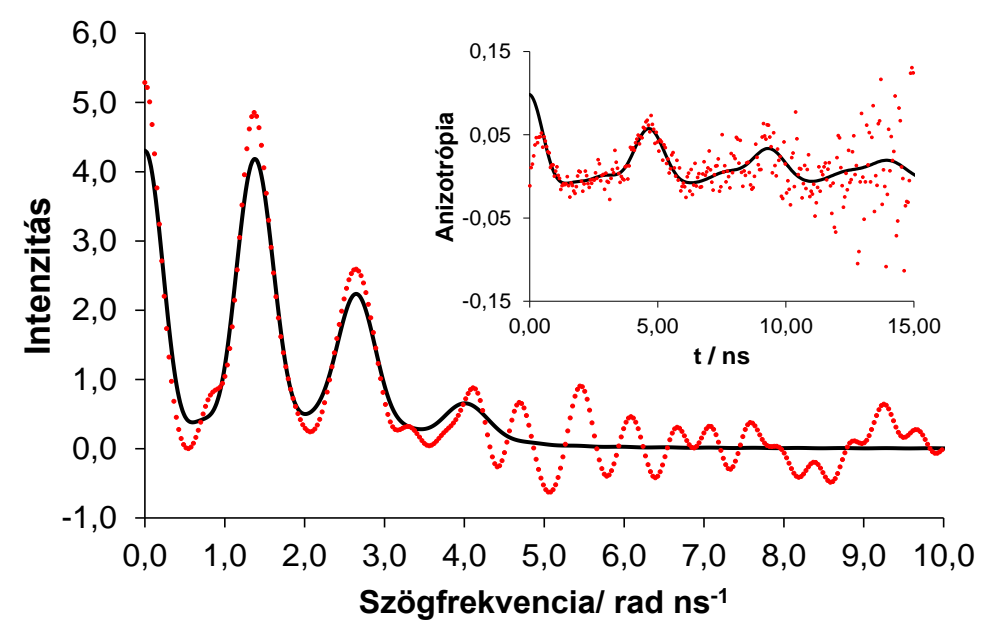

4.8.3. ábra: Egy Fourier-transzformáció előtti (beágyazott görbe) és a transzformáció utáni PAC spektrum A piros görbék a kísérleti adatok, míg a fekete görbék azok illesztései 
Az atommagok és az azt körülvevő erőtér közötti kölcsönhatás erősségére jellemző $\omega_{\mathrm{o}}\left(\right.$ ill. $\left.v_{\mathrm{Q}}=10 \times \omega_{\mathrm{o}} /(3 \pi)\right)$ és az elektromos tér szimmetria viszonyait leíró $\eta$ paramétereket a mért spektrumokból Fourier-transzformációt követően paraméterillesztéssel határozhatjuk meg (4.8.3. ábra). A PAC spektrumokban megfigyelhető sávok szélessége a koordinációs geometria flexibilitását jellemzi. A keskeny sávok merev konformációra utalnak, míg a széles sávok flexibilis, több lokális konformációs minimummal rendelkező szerkezetet jeleznek.

Összefoglalva, a módszer segítségével jellemezhető egy fémion lokális környezete (típus, koordinációs szám, koordinálódó atomok geometriai elrendeződése). Több koordinációs hely esetén pedig meghatározható egyfajta eloszlás a különböző geometriájú kötőhelyek között, illetve korábban említett molekuladinamikai információkat is kaphatunk.

Lars Hemmingsen és munkatársai kvantumkémiai számolásokkal (DFT) különböző kettes (lineáris és hajlított geometriák) és hármas koordinációs számú $\mathrm{Hg}^{2+}$-vegyületekben vizsgálták az elektromos térerő gradiens (EFG) alakulását [116]. Számításaik alapján az EFG-nek a ${ }^{199 m} \mathrm{Hg}$ PAC paraméterek szempontjából legfontosabb komponense különböző, egymást kioltó hatások miatt nagyon csekély mértékben érzékeny a lineáris geometria torzultságára, illetve a koordinálódó donorcsoport minőségére. Emiatt, noha a meghatározott $v_{\mathrm{Q}}$ paraméterekből mérvadó információkat nyerhetünk a fémion koordinációs számáról, azonban a lineáris és hajlított ketteskoordinációs számú szerkezetek, illetve a potenciálisan koordinálódó csoportok között rendkívül nehéz különbséget tenni.

A mérések alkalmával minden esetben $55 \%(\mathrm{~m} / \mathrm{m})$ koncentrációban szacharózt adtunk a mintákhoz, hogy a molekulák Brown-féle „tumbling” mozgását (rotációs diffúzió) csökkentsük. Ugyanilyen okból a méréseket Peltier-elemekkel szabályozott hőmérsékleten, $1^{\circ} \mathrm{C}$-on végeztük. Mivel a pufferek $\mathrm{p} K_{\mathrm{s}}$ értékei hőmérsékletfüggőek, ezért meghatároztuk, hogy milyen $\mathrm{pH}$ értéket állítsunk be az adott pufferoldatnak szobahőmérsékleten, hogy azt $1^{\circ} \mathrm{C}$-ra hütve a kívánt pH-t kapjuk [117].

A különböző összetételü $\mathrm{Hg}^{2+}$-HS, PS és PP minták PAC spektrumait a CERN-ben (Svájc), az ISOLDE laboratóriumban rögzítettük. $\mathrm{A} \mathrm{Hg}^{2+}$-ionok $\mathbf{H S}$ ligandummal alkotott komplexeit $\mathrm{pH}=2,0,8,0$ és 10,5 értékeken vizsgáltuk. A bázikus körülményeket TRIS ( $\mathrm{pH}$ $=8,0)$ és CAPS $(\mathrm{pH}=10,5)$ pufferek segítségével biztosítottuk. A $200 \mu \mathrm{L}$ térfogatú minták $150 \mu \mathrm{L}$ radioaktív ${ }^{199 m} \mathrm{Hg}^{2+}-\mathrm{t}$ tartalmaztak. Az oldatokban a ligandum koncentrációja $3,88 \times 10^{-5}$ és $8,02 \times 10^{-5} \mathrm{M}$ között változott, a $\mathrm{Hg}^{2+}$-ionok összkoncentrációja $4,64 \times 10^{-5} \mathrm{M}$ és $7,80 \times 10^{-5} \mathrm{M}$ tartományban volt. A radioaktív ${ }^{199 \mathrm{~m}} \mathrm{Hg}^{2+}$-ionok száma egy mintában $\sim 10^{10}-10^{12}$ darab volt. 


\section{Kísérleti eredmények és értékelésük}

\subsection{A vizsgált ligandumok összehasonlítása}

\subsubsection{A vizsgált ligandumok sematikus szerkezete}

Ac-SCP्PDQGSDCPII-NH 2 (Ac-Ser-Cys-Pro-Gly-Asp-Gln-Gly-Ser-Asp-Cys-Pro-Ile- $\mathrm{NH}_{2}$ ) (PP, V. cholerae baktérium CueR fehérjéjének fémkötő doménje):

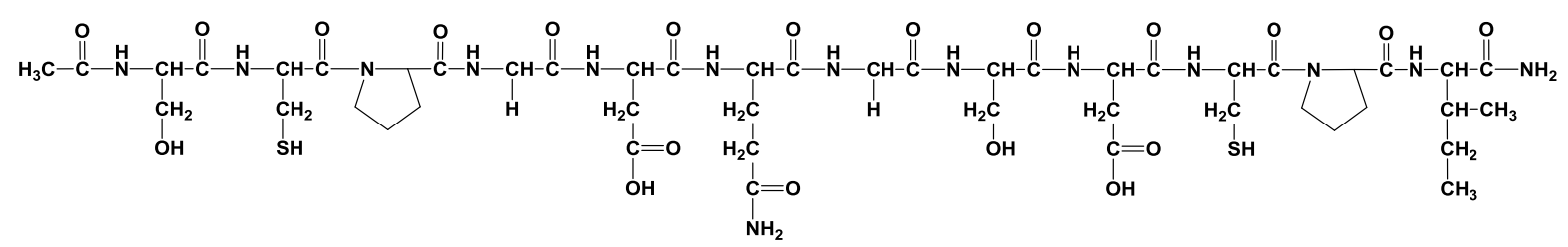

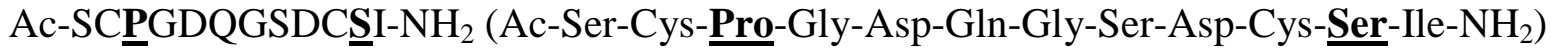
(PS, Az eredeti szekvencia fémkötő doménjében a 11-es pozíciójú prolint szerinre cseréltük):

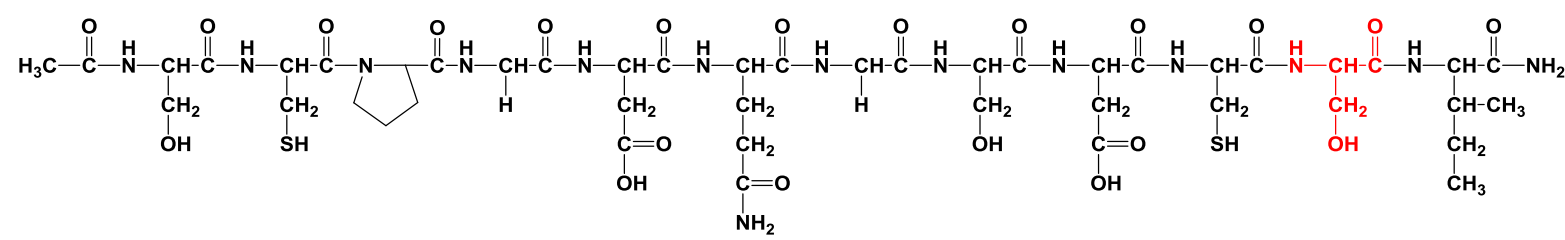

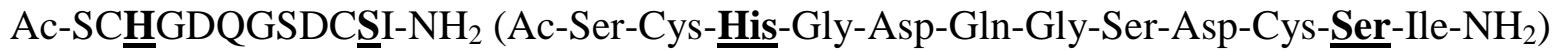
(HS, Az eredeti szekvencia fémkötő doménjében a 3-as és 11-es prolinokat hisztidinre és szerinre cseréltük):

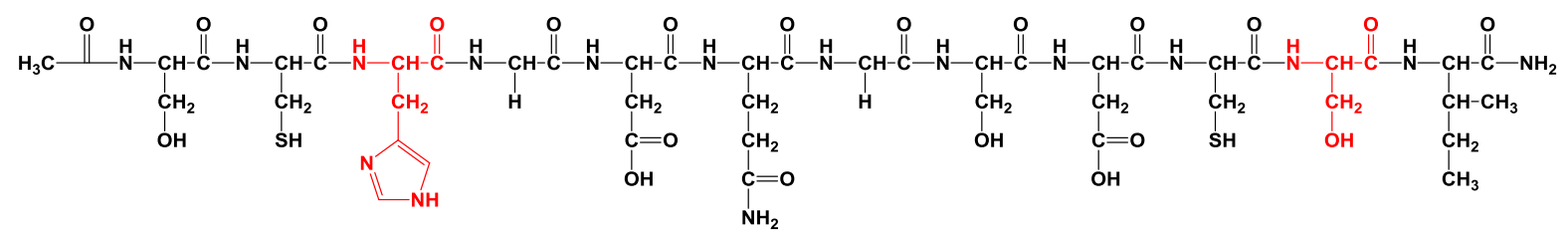

Ac-ACPGDDSADCPI-NH 2 (Ac-Ala-Cys-Pro-Gly-Asp-Asp-Ser-Ala-Asp-Cys-Pro-Ile- $\mathrm{NH}_{2}$ ) (EC, E. coli baktérium CueR fehérjéjének fémkötő doménje):

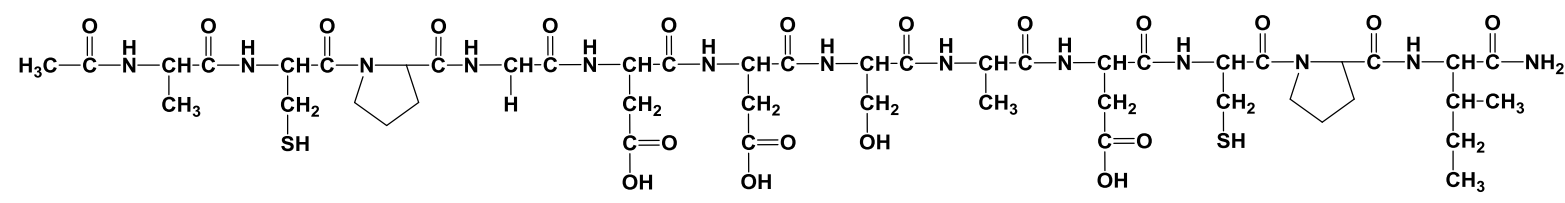




\subsubsection{A ligandumok pH-potenciometriás és UV spektroszkópiai vizsgálata}

Munkám során a ligandumok tisztítását követően első lépésben meghatároztuk a fémionokat nem tartalmazó rendszerben a szabad ligandumok $\mathrm{p} K_{\mathrm{s}}$ értékeit. A vizsgált dodekapeptidek négy (PP, PS) illetve öt (HS, EC) olyan csoportot tartalmaznak, melyek a pH növelésével deprotonálódnak (5.1.2.1. táblázat).

\begin{tabular}{lllll}
\hline & $\mathrm{p} K_{\mathrm{s}}(\mathbf{P P})$ & $\mathrm{p} K_{\mathrm{s}}(\mathbf{P S})$ & $\mathrm{p} K_{\mathrm{s}}(\mathbf{H S})$ & $\mathrm{p} K_{\mathrm{s}}(\mathbf{E C})$ \\
\hline Cys, - SH & 9,06 & 9,09 & 9,06 & 9,25 \\
Cys, -SH & 8,25 & 8,30 & 8,44 & 8,40 \\
His, -NH & - & - & 6,60 & - \\
Asp, -COOH & - & - & - & 4,75 \\
Asp, -COOH & 4,40 & 4,37 & 4,79 & 3,98 \\
Asp, -COOH & 3,38 & 3,50 & 3,50 & 3,09 \\
\hline
\end{tabular}

5.1.2.1. táblázat: A ligandumok potenciális donorcsoportjainak $\mathrm{p} K_{\mathrm{s}}$ értékei $\left(c_{\text {peptid }}=1,0 \times 10^{-3} \mathrm{M}, I=0,1 \mathrm{M} \mathrm{NaClO}_{4}, T=298 \mathrm{~K}\right)$

A ligandumok a $\mathrm{pH}$ 3-5 tartományban két, illetve három protont veszítenek, melyek az Asp aminosavak karboxilcsoportjaihoz rendelhetők. A HS peptid esetén egy további deprotonálódási folyamat játszódik le $\mathrm{pH}$ 6-7 környékén, mely a His imidazolcsoportjának protonvesztése, a $\mathrm{pH} \sim 8$-10 tartományban pedig a peptidek Cys alegységeinek tiolcsoportjai deprotonálódnak (5.1.2.1. ábra).

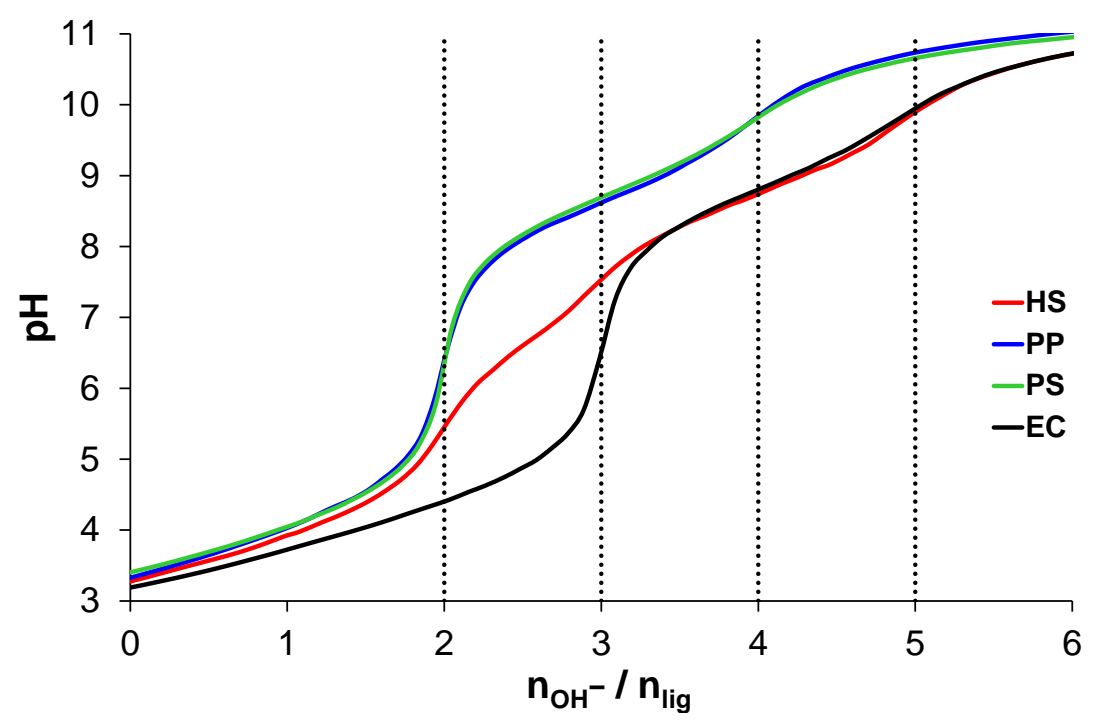

5.1.2.1. ábra: A peptidek normált titrálási görbéi $\left(c_{\text {Peptid }}=1,0 \times 10^{-3} \mathrm{M}, I=0,1 \mathrm{M} \mathrm{NaClO}_{4}, T=298 \mathrm{~K}\right)$

A tiolcsoportok deprotonálódásának hatására egy intenzív $\mathrm{n} \rightarrow \sigma^{*}$ átmenethez rendelhető sáv jelenik meg az UV spektrumokon [118, 119]. A ligandumok $\lambda=230$ nm-nél ábrázolt A vs. $\mathrm{pH}$ diagramjain az abszorbancia jelentős növekedése figyelhető meg a $\mathrm{pH}$ 710 tartományban, amely egyértelműen a Cys tiolcsoportjainak deprotonálódásának következménye (F1-F4. ábrák). 
Az 5.1.2.1. táblázat adatai alapján elmondható, hogy az extra donorcsoportok (HS, EC) megjelenése nem okoz szignifikáns változást a tiolcsoportok deprotonálódását jellemző $\mathrm{p} K_{\mathrm{s}}$ értékekben. Legfeljebb az EC peptidekben lehet intramolekuláris hidrogénkötéssel számolni.

\subsubsection{A ligandumok ${ }^{1}$ H NMR spektroszkópiai vizsgálatai}

A ligandumok komplexképződési folyamatainak ${ }^{1} \mathrm{H}$ NMR spektroszkópiával történő követéséhez elöször ${ }^{1} \mathrm{H}-{ }^{1} \mathrm{H}$ COSY és ${ }^{1} \mathrm{H}^{1} \mathrm{H}$ TOCSY spektrumok alapján elvégeztük a jelek hozzárendelését az aminosavak hidrogénjeihez (F5-F7. ábrák). Az aminosavak szekvenciabeli ismétlődése, valamint az átfedő jelek miatt ROESY spektroszkópiát alkalmaztunk, hogy az egyes hidrogénekhez tartozó jelek sorfejtését is elvégezhessük. A következőkben az azonosítást a PP ligandumon mutatom be.

$\mathrm{Az}$ aszparaginsav $\mathrm{C}_{\alpha} \mathrm{H}, \mathrm{C}_{\beta} \mathrm{H}_{2}$ és az amidhidrogének $(\mathrm{NH})$ jelei közötti kapcsolatot mindkét spektrumon keresztcsúcsok jelölik. A Gly-Asp-Gln szekvenciát az egyes aminosavak $\mathrm{C}_{\alpha} \mathrm{H}$ hidrogénjei és a következő aminosav alegység amidhidrogénjei közötti csatolások megjelenésén keresztül azonosíthatjuk.

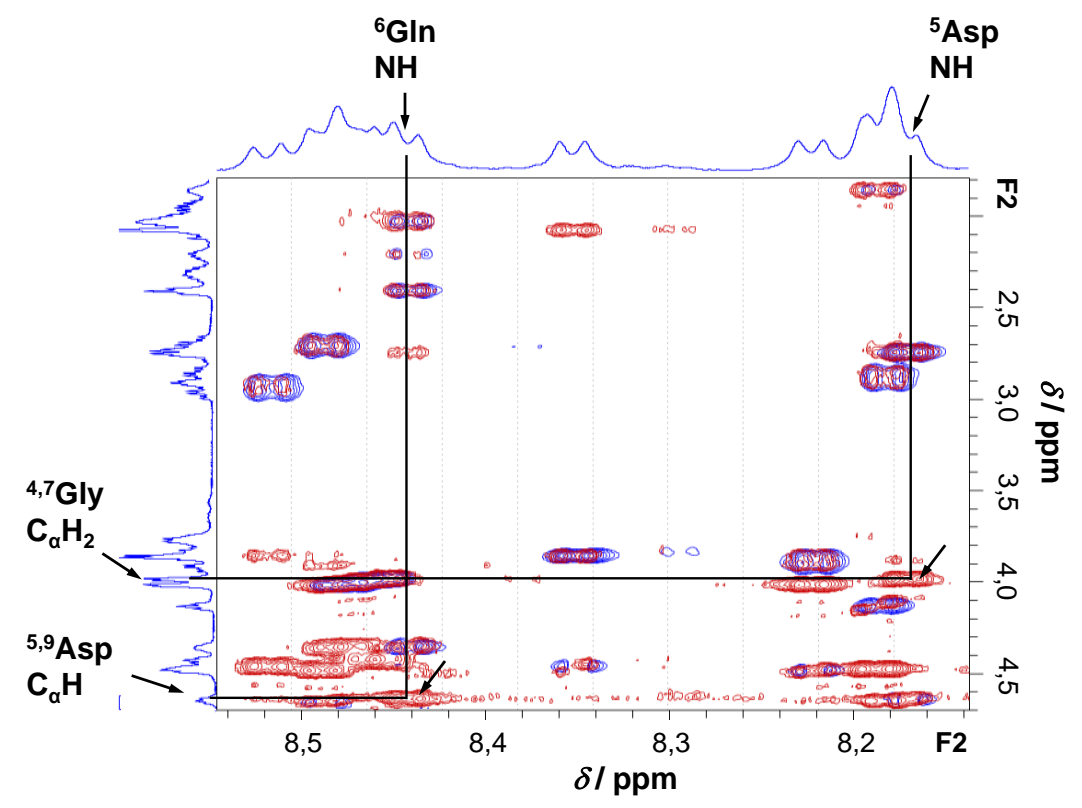

5.1.3.1. ábra: A szabad PP ligandum TOCSY és ROESY spektruma az amidhidrogének tartományában. Kékkel jelölve látható a TOCSY, míg pirossal a ROESY spektrum azonos részlete. A Gly-Asp-Gln kapcsolatot bizonyító keresztcsúcsokat a fekete vonalak metszéspontjai és a nyilak jelölik ki. $\left(c_{\mathbf{P P}}=2,6 \times 10^{-3} \mathrm{M}, \mathrm{H}_{2} \mathrm{O} / \mathrm{D}_{2} \mathrm{O}=90 / 10 \% \mathrm{v} / \mathrm{v}, I=0,1 \mathrm{M} \mathrm{NaClO}_{4}, \mathrm{pH}=4,95, T=298 \mathrm{~K}\right)$

A glicinek $\mathrm{C}_{\alpha} \mathrm{H}_{2}$ hidrogénjei $(\delta \sim 3,99$ ppm) csak a 8,17 ppm kémiai eltolódású amidhidrogénnel adnak keresztcsúcsot, amelyek az 5. Asp amidhidrogénjéhez rendelhetők. A $\delta=8,44$ ppm-nél található jel (a Gln NH csoport hidrogénjéhez tartozik) pedig az Asp 
$\mathrm{C}_{\alpha} \mathrm{H}$ csoportjával mutat csatolást. A kétdimenziós spektrumok segítségével ily módon a teljes peptidszekvencia feltérképezhetö, így az ${ }^{1} \mathrm{H}$ NMR spektrumokon megjelenő rezonanciák azonosíthatók (5.1.3.2.A/B ábra).

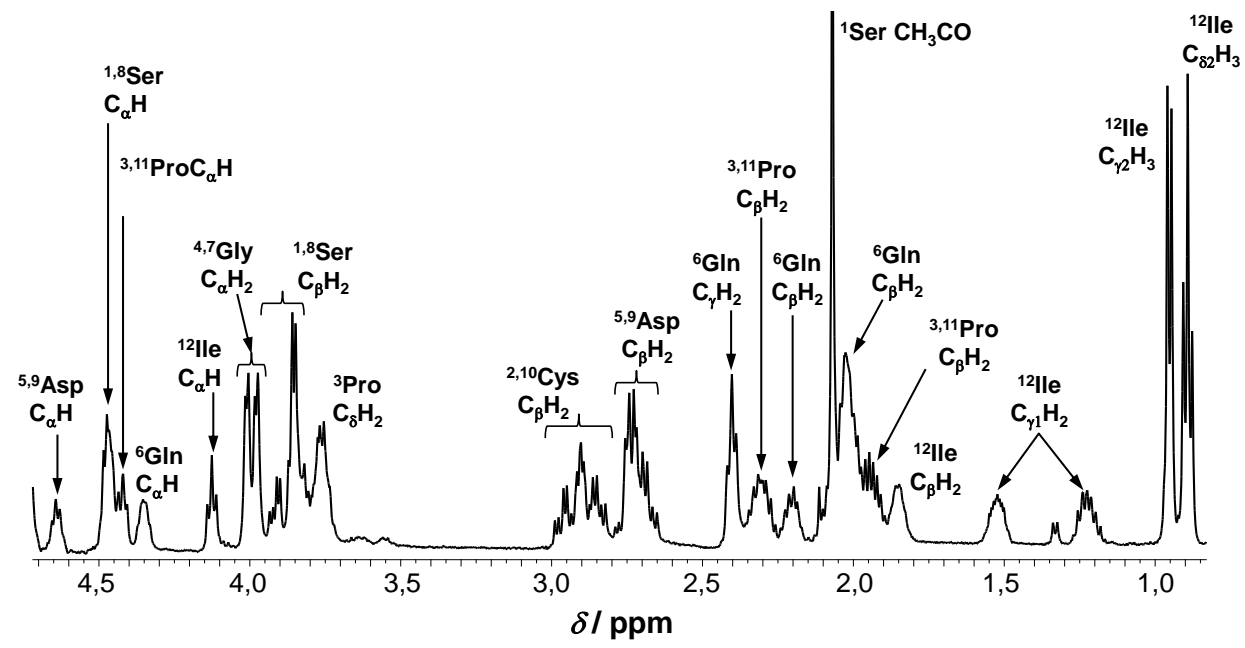

5.1.3.2/A ábra: A PP ligandum ${ }^{1} \mathrm{H}$ rezonanciáinak azonosítása az alifás hidrogének tartományában $\left(c_{\mathbf{P P}}=2,6 \times 10^{-3} \mathrm{M}, \mathrm{H}_{2} \mathrm{O} / \mathrm{D}_{2} \mathrm{O}=90 / 10 \% \mathrm{v} / \mathrm{v}, I=0,1 \mathrm{M} \mathrm{NaClO}_{4}, \mathrm{pH}=4,95, T=298 \mathrm{~K}\right)$

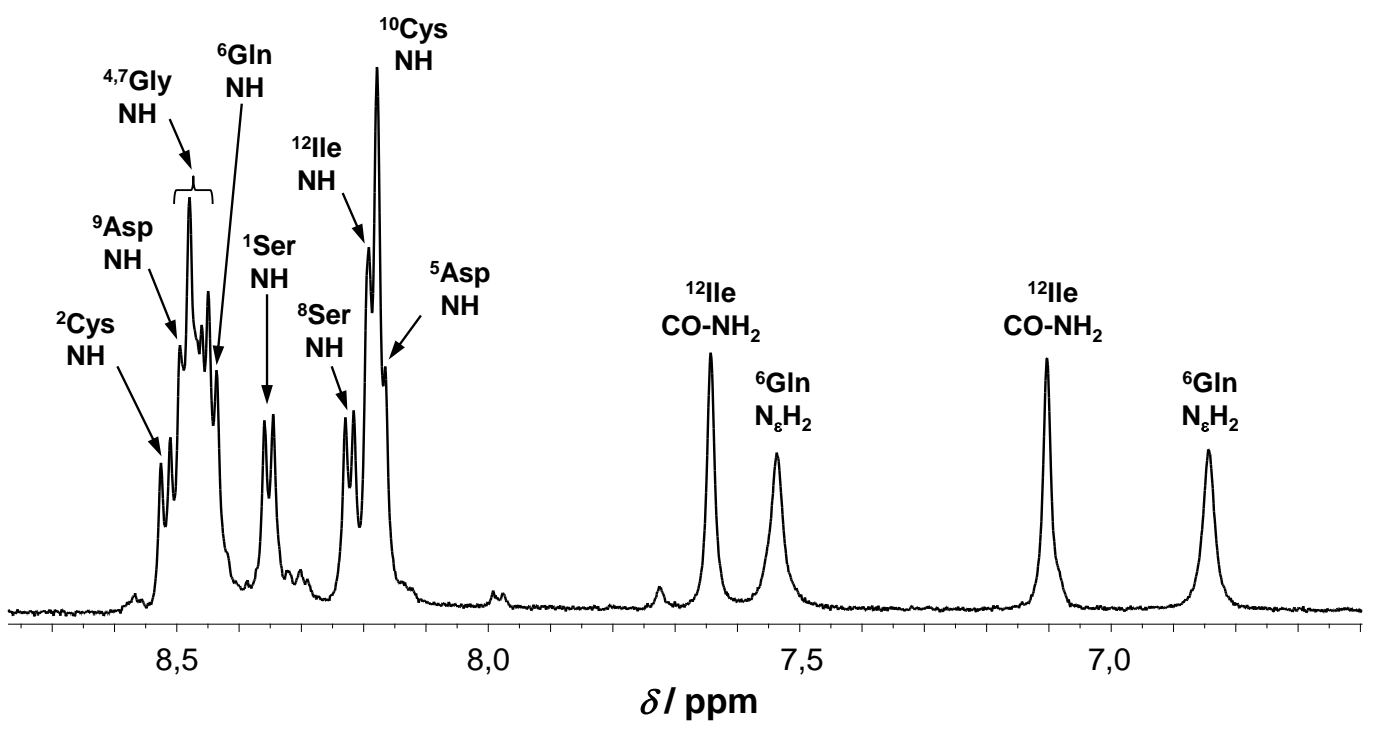

5.1.3.2/B ábra: A PP ligandum ${ }^{1} \mathrm{H}$ rezonanciáinak azonosítása az aromás hidrogének tartományában $\left(c_{\mathbf{P P}}=2,6 \times 10^{-3} \mathrm{M}, \mathrm{H}_{2} \mathrm{O} / \mathrm{D}_{2} \mathrm{O}=90 / 10 \% \mathrm{v} / \mathrm{v}, I=0,1 \mathrm{M} \mathrm{NaClO}_{4}, \mathrm{pH}=4,95, T=298 \mathrm{~K}\right)$

A peptidek deprotonálódási folyamatainak hatását a HS ligandum pH-függő NMR spektrumain szemléltetem. A His imidazolcsoportjának $(\mathrm{pH}>5,5)$ és a két Asp karboxilcsoportjainak $(\mathrm{pH}>3,5)$, valamint a két Cys tiolcsoportjainak protonvesztésével $(\mathrm{pH}>7,5)$ párhuzamosan a $\mathrm{C}_{\beta} \mathrm{H}_{2}$ jeleik kémiai eltolódása $\mathrm{pH}$-függő változást mutat (5.1.3.3. ábra). 


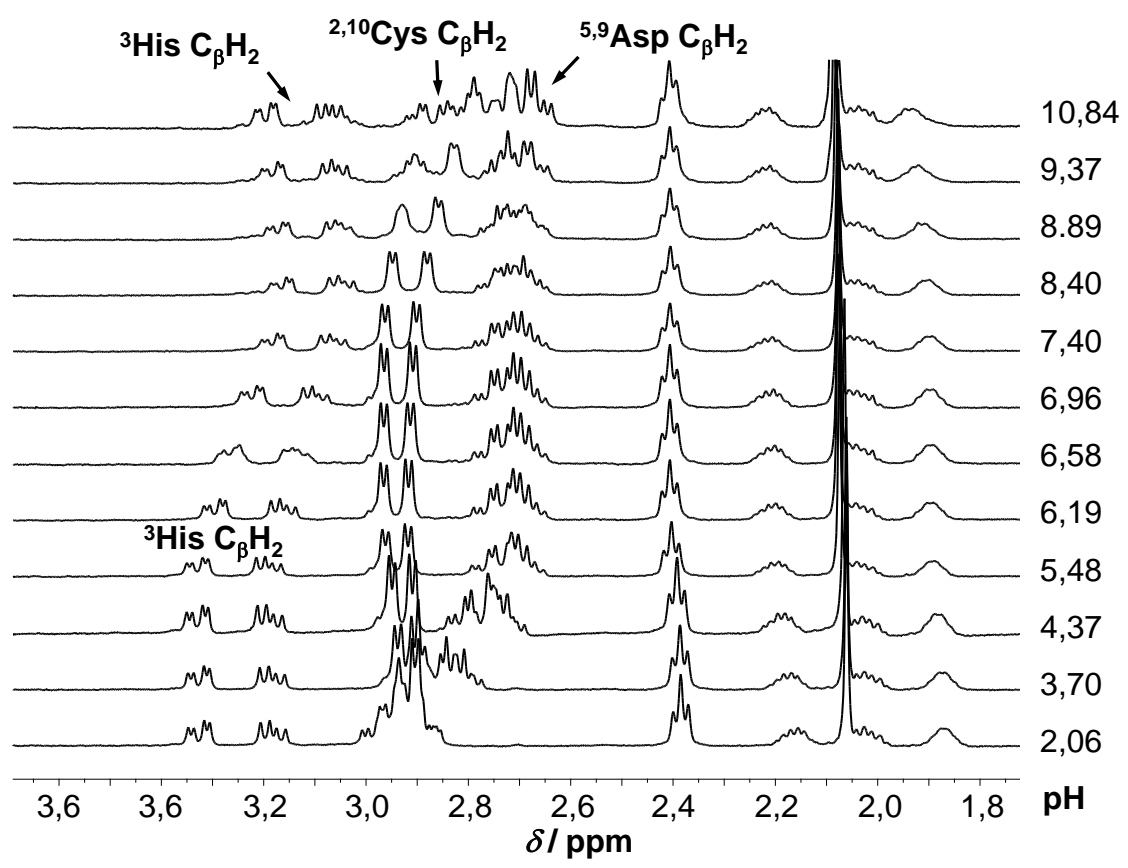

5.1.3.3. ábra: A HS ligandum pH-függő ${ }^{1} \mathrm{H}$ NMR spektrumainak részlete az alifás hidrogének tartományában $\left(c_{\text {HS }}=1,3 \times 10^{-3} \mathrm{M}, \mathrm{H}_{2} \mathrm{O} / \mathrm{D}_{2} \mathrm{O}=90 / 10 \% \mathrm{v} / \mathrm{v}, I=0,1 \mathrm{M} \mathrm{NaClO}_{4}, T=298 \mathrm{~K}\right)$

A His imidazolcsoportjának deprotonálódása továbbá az imidazolgyürü $\mathrm{C}_{\varepsilon 1} \mathrm{H}$ illetve $\mathrm{C}_{\delta 2} \mathrm{H}$ rezonanciáinak eltolódását és kiszélesedését eredményezi (5.1.3.4. ábra). A nagyobb tereknél (alacsonyabb ppm értéknél) lévő $\mathrm{C}_{\varepsilon 1} \mathrm{H}$ jel változásából a deprotonálódási állandó becsülhető ( $\mathrm{p} K_{\mathrm{His}} \sim 6,7$ ), amely jó egyezést mutat a korábban $\mathrm{pH}$-potenciometriás módszerrel meghatározott értékkel $\left(\mathrm{p} K_{\text {His }}=6,60\right)$.

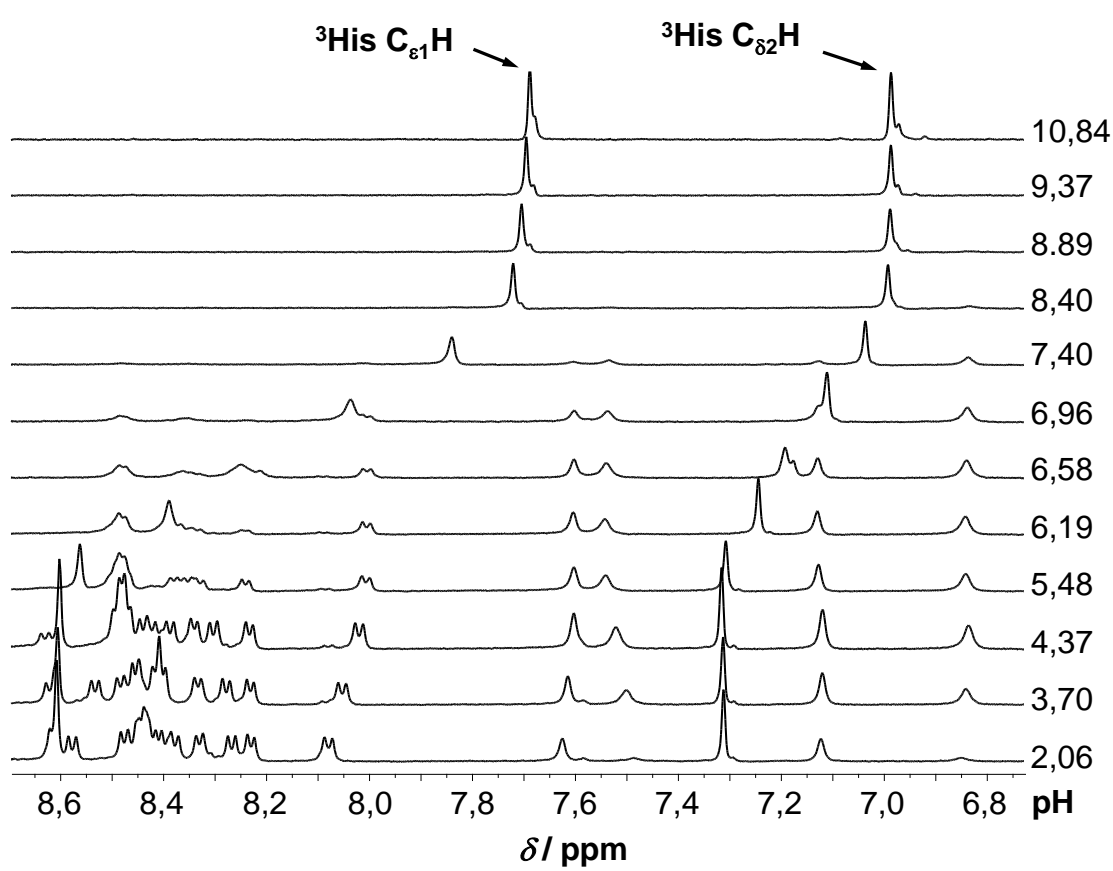

5.1.3.4. ábra: A HS ligandum pH-függő ${ }^{1} \mathrm{H}$ NMR spektrumainak részlete az aromás hidrogének tartományában $\left(c_{\mathrm{HS}}=1,3 \times 10^{-3} \mathrm{M}, \mathrm{H}_{2} \mathrm{O} / \mathrm{D}_{2} \mathrm{O}=90 / 10 \% \mathrm{v} / \mathrm{v}, I=0,1 \mathrm{M} \mathrm{NaClO}_{4}, T=298 \mathrm{~K}\right)$ 
A PP és PS peptidek pH-függő spektrumai nagy hasonlóságot mutatnak a HS liganduméval (F9-F10. ábrák). Az EC peptid pH-függő spektrumain a deprotonálódási folyamatok követését a jelek jelentős szélesedése akadályozta (F11. ábra).

Az aromás hidrogének tartományában ( $\delta=6,8-8,6$ ppm között) az amidnitrogének protonjaihoz rendelhető jelek a $\mathrm{pH}$ növelésének hatására teljesen eltünnek a vízzel történő intenzív cserefolyamat következtében.

A hisztidin $\mathrm{C}_{\varepsilon 1} \mathrm{H}$ illetve $\mathrm{C}_{\delta 2} \mathrm{H}$ jelein lúgos $\mathrm{pH}$-tartományban látható kis váll megjelenését nagy valószínűséggel a Cys tiolcsoportjainak oxidációja (intra- és/vagy intermolekuláris diszulfid-hidak kialakulása) okozza, amelyet hosszabb idő elteltével már savas körülmények között is tapasztalhatunk, amennyiben nem gondoskodunk inert atmoszféráról (F8. ábra).

\subsubsection{A ligandumok CD spektroszkópiai vizsgálatai}

A rövid peptidek általában nem képesek egy adott stabilis másodlagos szerkezet kialakítására, ebből adódóan CD spektrumok nem diszkrét konformációkhoz, hanem azok populációihoz rendelhetők. A spektrumok alakja tehát egy adott konformációs (szerkezeti) eloszlást, illetve ennek megváltozását jellemzi.
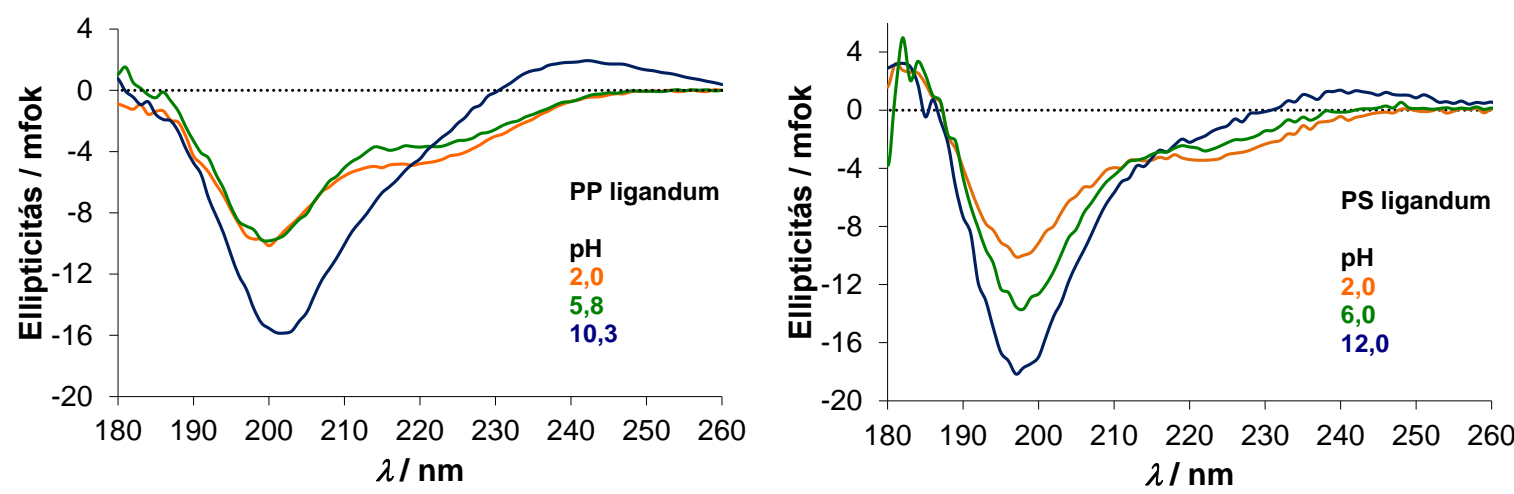

5.1.4.1. ábra: $A \mathbf{P P}$ és a $\mathbf{P S}$ ligandumok $C D$ spektrumai különböző $\mathrm{pH}$ értékeknél rögzítve

$$
\left(c_{\mathbf{P P} / \mathbf{P S}}=1,0 \times 10^{-4} \mathrm{M}, I=0,1 \mathrm{M} \mathrm{NaClO}_{4}, l=1 \mathrm{~mm}, T=298 \mathrm{~K}\right)
$$

Az 5.1.4.1. ábrán megfigyelhető, hogy a savas körülmények között $(\mathrm{pH}=2,0)$ mért spektrumok alakja megváltozik a $\mathrm{pH} \sim 6,0$-ra. Ebben a $\mathrm{pH}$ tartományban történik ugyanis a két Asp karboxilcsoportjának deprotonálódása, melynek révén a peptideken növekszik a negatív töltésű csoportok száma. Ennek következtében az elektrosztatikus kölcsönhatások megváltoznak, de a molekula és az oldószer között kialakuló esetleges hidrogénkötésrendszer átalakulása is feltételezhető. A negatív töltéssel rendelkező karboxilcsoportok taszítani fogják egymást, ennek következtében bizonyos konformációk a savas körülményekhez képest gátoltak, míg más konformációk kedvezményezettek lesznek. 
A pH = 6-12 között a Cys egységek tiolcsoportjai deprotonálódnak, ami a negatív töltések számának további növekedését okozza. A $\lambda$ 198 nm-nél jelenlévő csúcs intenzitása nő, illetve 240 nm-nél pozitív csúcs jelenik meg a spektrumon. Érdemes megjegyezni, hogy ez utóbbi jelenség azoknál a peptidjeinknél figyelhető meg, melyekben prolin is található.

A hisztidint is tartalmazó peptiddel (HS) végzett $\mathrm{CD}$ vizsgálatok során a $\mathrm{pH}$ növelésével csupán egyetlen spektroszkópiailag érzékelhető változást tapasztaltunk. Mivel ez $\mathrm{pH}=$ 6-7 tartományban játszódik le, ezért a végbemenő konformáció változásért valószínüleg a His imidazol oldalláncának deprotonálódása a felelős. Az Asp karboxil- és a Cys tiolcsoportjainak protonvesztése érdekes módon nem okoz érzékelhető változást a molekula szerkezetében (5.1.4.2. ábra).

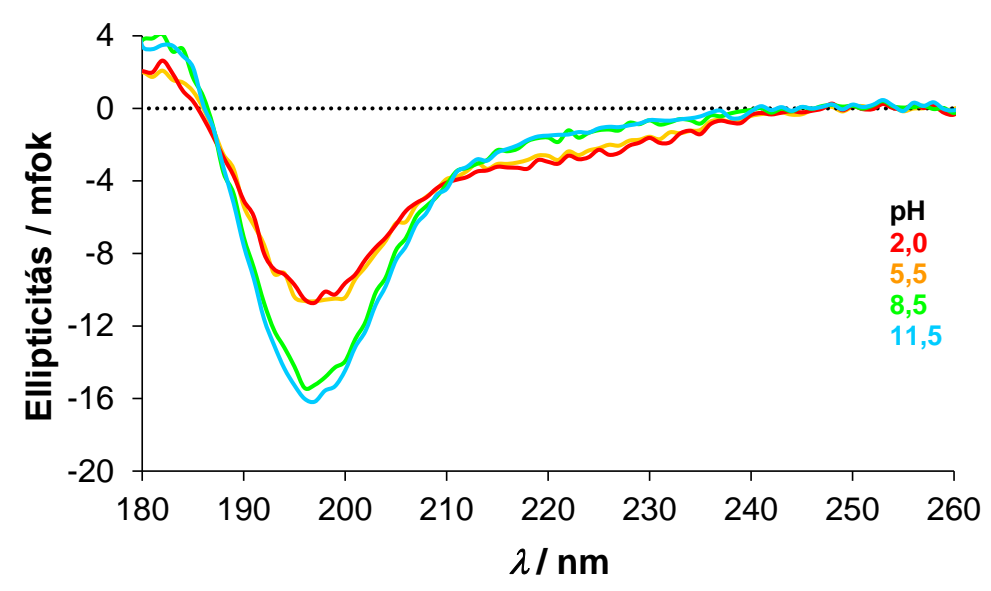

5.1.4.2 ábra: A HS ligandum különböző pH-értékeknél mért SRCD spektrumai $\left(c_{\mathrm{HS}}=1,0 \times 10^{-3} \mathrm{M}, I=0,1 \mathrm{M} \mathrm{NaClO}_{4}, l=0,1 \mathrm{~mm}, T=298 \mathrm{~K}\right)$ 


\subsection{A ligandumok $\mathrm{Zn}^{2+}$-, és $\mathrm{Cd}^{2+}$-ionok komplexeinek vizsgálata}

A $\mathrm{Zn}^{2+}$ - és $\mathrm{Cd}^{2+}$-tartalmú rendszerekben lejátszódó komplexképződési, illetve egyensúlyi folyamatokat UV-, NMR-, (SR)CD- és PAC spektroszkópiai mérések és pHpotenciometriás titrálások segítségével követtük.

\subsubsection{A hisztidint nem tartalmazó ligandumok $\mathrm{Zn}^{2+}$-, és $\mathrm{Cd}^{2+}-$ komplexei}

5.2.1.1. Az ekvimoláris $\mathrm{Zn}^{2+}$-, és $C d^{2+}$-ionokat tartalmazó rendszerek vizsgálata

A pH-metriás adatok kiértékelése során számolt bruttó stabilitási állandókat és néhány származtatott értéket az 5.2.1.1.1. táblázat foglalja össze, amelyre a későbbiekben többször is hivatkozni fogok.

\begin{tabular}{|c|c|c|c|c|c|c|c|c|}
\hline \multirow{2}{*}{$\mathbf{M}_{\mathbf{p}} \mathbf{H}_{\mathbf{q}} \mathbf{L}_{\mathbf{r}}$} & \multicolumn{2}{|c|}{$\mathbf{P P}$} & \multicolumn{2}{|c|}{ PS } & \multicolumn{2}{|l|}{ EC } & \multicolumn{2}{|c|}{ HS } \\
\hline & $\lg \beta$ & $\mathbf{p} \boldsymbol{K}_{s}$ & $\lg \beta$ & $\mathbf{p} \boldsymbol{K}_{s}$ & $\lg \beta$ & $\mathbf{p} \boldsymbol{K}_{s}$ & $\lg \beta$ & $\mathbf{p} K_{s}$ \\
\hline ZnHL & $15,19(8)$ & 5,39 & $14,95(8)$ & 5,02 & $15,39(14)$ & 4,67 & $16,58(2)$ & 5,95 \\
\hline ZnL & $9,80(2)$ & $\mathbf{9 , 5 3}$ & $9,93(2)$ & 9,11 & $10,56(4)$ & 9,61 & $10,63(2)$ & 8,65 \\
\hline $\mathbf{Z n H}_{-1} \mathbf{L}$ & $0,27(4)$ & - & $0,82(4)$ & 10,50 & - & - & $1,98(3)$ & - \\
\hline $\mathbf{Z n H}_{-2} \mathbf{L}$ & - & - & $-9,68(4)$ & - & - & - & - & - \\
\hline $\mathrm{ZnHL}_{2}$ & $22,98(9)$ & 8,41 & $23,0(1)$ & 8,28 & $23,77(12)$ & 8,95 & $23,74(7)$ & 8,72 \\
\hline $\mathrm{ZnL}_{2}$ & $14,57(6)$ & - & $14,72(7)$ & - & $14,82(8)$ & - & $15,02(7)$ & - \\
\hline $\mathbf{Z n}_{2} \mathbf{H}_{-1} \mathbf{L}_{2}$ & - & - & - & - & $15,16(21)$ & 9,89 & - & - \\
\hline $\mathbf{Z n}_{2} \mathbf{H}_{-2} \mathbf{L}_{2}$ & - & - & - & - & $5,27(14)$ & - & - & - \\
\hline CdHL & $16,31(3)$ & 4,71 & $16,33(3)$ & 4,72 & $16,90(9)$ & 6,46 & $18,24(3)$ & 6,46 \\
\hline CdL & $11,60(2)$ & 11,47 & $11,61(2)$ & 11,17 & $12,24(4)$ & - & $11,78(4)$ & 10,36 \\
\hline $\mathrm{CdH}_{-1} \mathrm{~L}$ & $0,13(4)$ & - & $0,44(4)$ & - & - & - & $1,42(6)$ & - \\
\hline $\mathrm{CdHL}_{2}$ & $25,2(1)$ & 7,41 & $25,2(2)$ & 7,45 & $25,88(13)$ & 8,26 & $26,23(8)$ & 8,00 \\
\hline $\mathrm{CdL}_{2}$ & $17,81(6)$ & - & $17,70(8)$ & - & $17,62(9)$ & - & $18,23(7)$ & - \\
\hline $\mathrm{Cd}_{2} \mathrm{H}_{-1} \mathrm{~L}_{2}$ & - & - & - & - & $17,93(23)$ & - & - & - \\
\hline
\end{tabular}

5.2.1.1.1. táblázat: A ligandumok $\mathrm{Zn}^{2+}{ }_{-}$, és $\mathrm{Cd}^{2+}-$ komplexeinek stabilitási állandói $(\lg \beta)$ és az ebböl származtatott értékek (az utolsó tizedesjegyre vonatkozó becsült hibák zárójelben) 
A fémiont tartalmazó rendszerek tárgyalásakor az eredményeket és azok értékelését a natív PP peptiden mutatom be, a jobb áttekinthetőség érdekében. $\mathrm{A} \mathrm{Zn}^{2+}-\mathbf{P P}$ és $\mathrm{Cd}^{2+}-\mathbf{P P}$ rendszerek titrálási görbéi az F12. ábrán láthatók. A meghatározott képződési állandók ismeretében a kísérleti körülményeknek megfelelő koncentrációra $\left(1,0 \times 10^{-3} \mathrm{M}\right)$ eloszlási diagramokat számoltunk. 1:1 fémion:ligandum arány esetén egyszerü részecske-eloszlási modellt kaptunk. $\mathrm{Zn}^{2+}$-ionok jelenlétében az első protonált monokomplex $\mathrm{pH} \sim 4$ felett jelenik meg. Mivel a ligandum $\mathrm{p} K_{\mathrm{s}}$ értékei (5.1.2.1. táblázat) azt mutatják, hogy a szabad ligandum titrálása során az Asp karboxilcsoportok deprotonálódása is a $\mathrm{pH} \sim 3-5$ tartományban történik, ezért pusztán ezen eredmények alapján nem állapítható meg, hogy a karboxilcsoportok valamelyike részt vesz-e a fémion megkötésében. A ZnHL részecske deprotonálódásával kialakuló $\mathrm{ZnL}$ törzskomplex jelenléte $\mathrm{pH} \sim$ 6-9 között domináns (5.2.1.1.1. ábra). A komplex képződéshez rendelhető deprotonálódási állandó értéke (ZnHL $\rightarrow \mathrm{ZnL} ; \mathrm{p} K_{\mathrm{s}}=4,5-6,0$ között az összes vizsgált peptidre) több nagyságrenddel kisebb, mint a szabad ligandumokban található Cys tiolcsoportok deprotonálódásához rendelhető $\mathrm{p} K_{\mathrm{s}}$ értékek (5.1.2.1. táblázat).
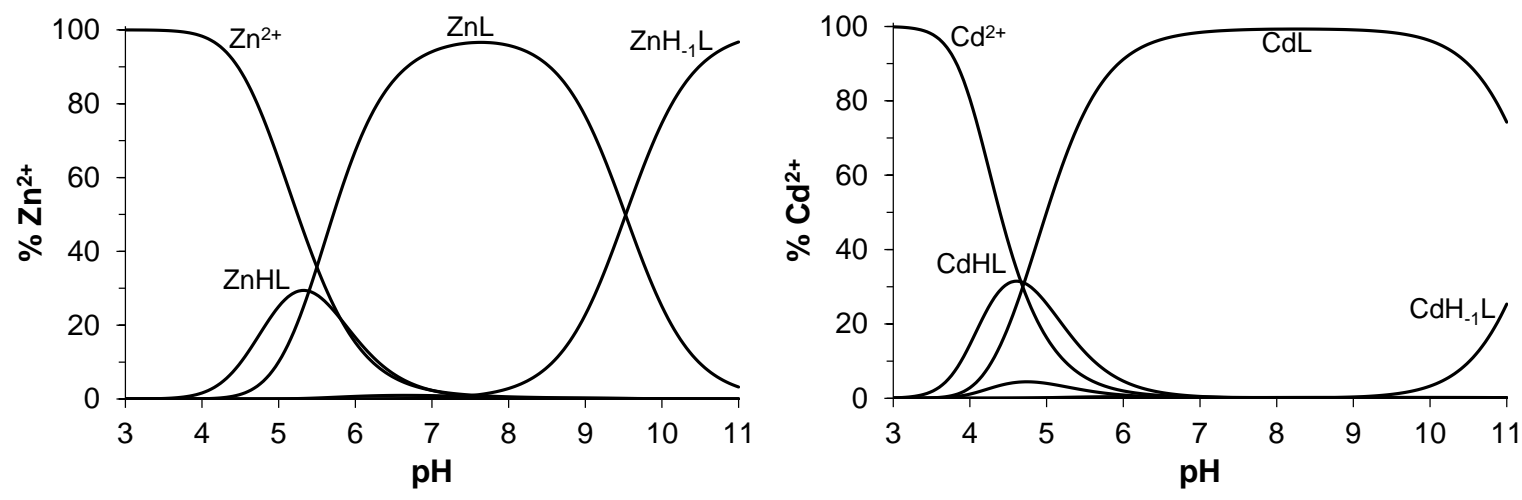

5.2.1.1.1. ábra: $\mathrm{A} \mathrm{Zn}^{2+}$ - és $\mathrm{Cd}^{2+}$-PP $1: 1$ fémion ligandum arányú rendszerek eloszlási diagramjai $\left(c_{\mathbf{P P}}=1,0 \times 10^{-3} \mathrm{M}, I=0,1 \mathrm{M} \mathrm{NaClO}_{4}, T=298 \mathrm{~K}\right)$

A $\mathrm{Cd}^{2+}$-iont és PP ligandumot 1:1 arányban tartalmazó rendszerben a komplexképződési folyamatok $\mathrm{pH} \sim$ 3,5-től indulnak el (5.2.1.1.1. ábra). A CdL komplex kialakulásához rendelhető állandó értéke $\left(\mathrm{p} K_{\mathrm{s}}=4,71\right)$ szintén több nagyságrenddel alacsonyabb a szabad PP tiolcsoportjainak deprotonálódásánál (5.1.2.1. táblázat), amely mindkét fémionnál azt mutatja, hogy jelenlétük elősegíti a tiolcsoportok disszociációját.

A komplexképződést kísérő $\mathrm{S}^{-} \rightarrow$ fémion töltésátviteli sávok megjelenésével következtethetünk a Cys tiolcsoportok koordinációjára, amely UV spektroszkópiai mérésekkel nyomonkövethető (F17. ábra). A PP ligandum $\mathrm{S}^{-} \rightarrow \mathrm{Zn}^{2+} / \mathrm{Cd}^{2+}$ töltésátviteli sávján $(\lambda=230 / 250 \mathrm{~nm}[120])$ a $\mathrm{pH}=4-7$ tartományban abszorbancia-növekedést láthatunk (5.2.1.1.2. ábra). 

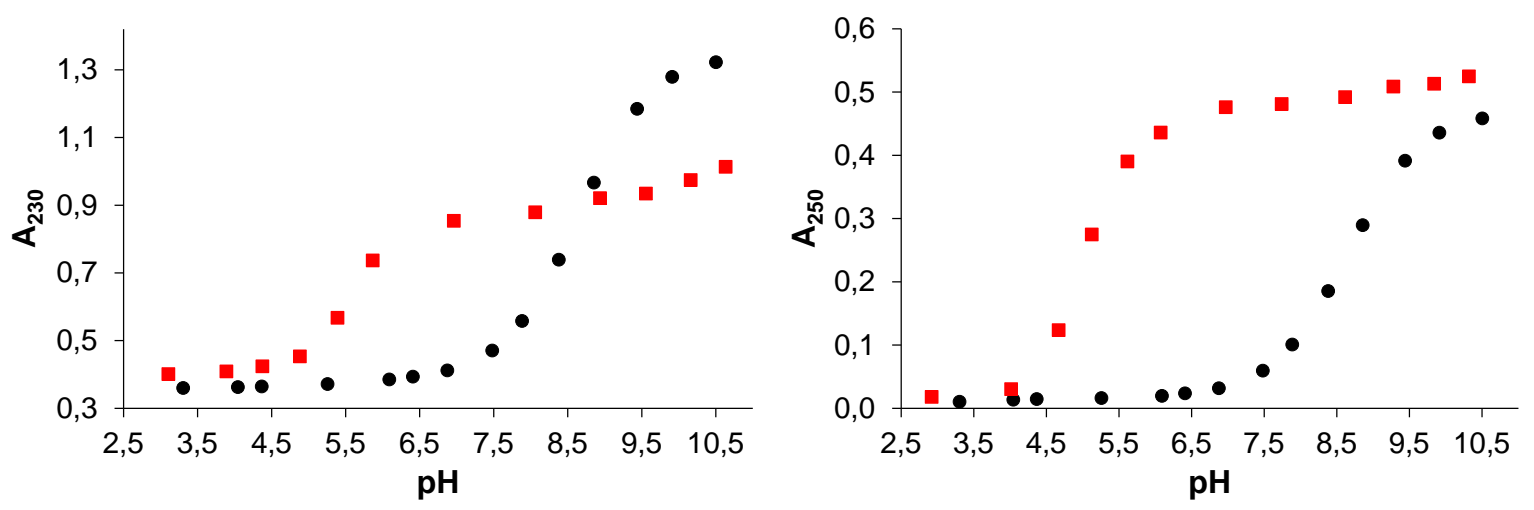

5.2.1.1.2. ábra: $\mathrm{Zn}^{2+}-\mathbf{P P}$ (bal) és a $\mathrm{Cd}^{2+}-\mathbf{P P}$ (jobb) $1: 1$ fémion:ligandum arányú rendszerek $\mathrm{A}$ vs. pH görbéje

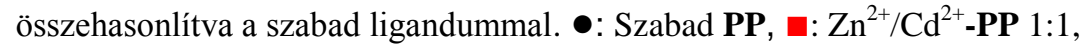
$\left(c_{\mathbf{P P}}=1,0 \times 10^{-4} \mathrm{M}, I=0,1 \mathrm{M} \mathrm{NaClO}_{4}, l=10 \mathrm{~mm}, T=298 \mathrm{~K}\right)$

Ez a jelenség a szabad ligandum tiolcsoportjainak deprotonálódása során csak pH > 7-től figyelhető meg. A potenciometriás és UV spektroszkópiai eredmények alapján arra következtethetünk, hogy az MHL részecskékben az egyik tiolcsoport kötődik a fémionokhoz, míg a másik még protonált állapotban van. A pH további növelésével $\mathrm{ML}$ törzskomplex válik uralkodóvá ( $\mathrm{pH} \sim 6-10)$, amelyben minden valószínűség szerint a ligandum mindkét tiolcsoportja koordinálódik a fémionokhoz. Fontos megjegyezni, hogy a komplexképződés $\mathrm{Cd}^{2+}$-ionok jelenlétében körülbelül egy $\mathrm{pH}$ egységgel alacsonyabban kezdődik, mint $\mathrm{Zn}^{2+}$-ionok esetén, ami a $\mathrm{Cd}^{2+}$-ionok tiolcsoportokhoz való nagyobb affinitásával magyarázható.

Bázikus körülmények között a törzskomplexek deprotonálódását minden esetben abszorbancia-növekedés kíséri (5.2.1.1.2. ábra). A ligandumban az említettek mellett nincs több potenciális donorcsoport, ugyanis a terminálisan védett peptidekre nem jellemző a fémion-indukált amidcsoport koordinálódás [103, 104, 117-120]. Ezek alapján egy koordinált vízmolekula deprotonálódása történhet meg $\left(\mathrm{ML} \rightarrow \mathrm{MH}_{-1} \mathrm{~L}\right)$, amit követően az uralkodó részecske $\mathrm{M}(\mathrm{OH}) \mathrm{L}$ hidroxo-vegyeskomplex. Ez a folyamat a $\mathrm{Zn}^{2+}$-komplexekben a $\mathrm{Cd}^{2+}$-komplexekhez képest kisebb pH-n játszódik le, melynek oka a $\mathrm{Zn}^{2+}$-ionok erősebb Lewis sav karakterében keresendő. A hidrolízist követő eltérő spektrális változásból valószínűsíthető, hogy a hidroxid-koordináció míg a $\mathrm{Zn}^{2+}$-ionok koordinációs környezetében szignifikáns átrendeződést eredményez, addig a $\mathrm{Cd}^{2+}$-komplexek szerkezetére gyakorolt hatása csekély.

A PS peptid a fentiekhez hasonló koordinációs tulajdonságokat mutatott (F15. és F18. ábrák). Az EC peptid esetén azonban a lúgos tartományban a titrálási görbéket nem tudtuk megilleszteni $\mathrm{MH}_{-1} \mathrm{~L}$ komplex feltételezésével. Ezért egy $\mathrm{M}_{2} \mathrm{H}_{-1} \mathrm{~L}_{2}$ dimer részecske 
jelenlétét feltételeztük (F26-F28. ábrák). A dimer részecske létezését azonban sem az UV-, sem a CD spektroszkópiai eredményekböl nem tudtuk megerösíteni.

Továbbá az is nehézséget okoz, hogy az EC peptid NMR spektrumain a jelek fémion jelen-, és távollétében a pH növelésével egyaránt kiszélesednek, így a csúcsok azonosítása nehéz (F36-F37. ábrák).

Ligandumaink fémkomplexeinek stabilitását érdemes összehasonlítani más, két ciszteint tartalmazó peptidek komplexeivel, melyeket az 5.2.1.1.2. táblázatba gyüjtöttünk össze. A hosszabb láncú, 10-, és 13-tagú peptideket vizsgálva $\mathrm{Zn}^{2+}$, illetve $\mathrm{Cd}^{2+}$-ionok jelenlétében csak monokomplexeket detektáltak. A biszkomplexeinek hiánya azzal magyarázható, hogy a második ligandum koordinálódása a fémionhoz sztérikusan gátolt, valamint a peptidek esetleges pozitív/negatív oldalláncainak elektrosztatikus taszítása is okozhatja azt, hogy csak ML részecskék alakulnak ki. A 10-tagú peptidek két-, illetve három hisztidint is tartalmaznak, melyek szintén részt vehetnek a fémion koordinációjában. Ez a hatás az Ac-EEGCCHGHHE- $\mathrm{NH}_{2}$ oligopeptidben a legjelentősebb, ahol a három hisztidin jelenléte a legmagasabb stabilitási értéket eredményezi mindkét fémion esetén. Érdekesség azonban, hogy ezekben a peptidekben Asp karboxilcsoport koordinációját kizárták, addig az oldallánci karboxilcsoportok az általunk vizsgált komplexekben részt vehetnek a fémionkötésben.

A PS és PP ligandumok csak egy aminosavban különböznek egymástól. Ennek megfelelően komplexeik stabilitási állandói is nagy hasonlóságot mutatnak. A PS prolinját hisztidinre cserélve azonban kismértékü növekedést láthatunk a $\lg \beta$ értékekben, amit az előzőekhez hasonlóan His egység extra stabilizáló hatása okozhatja. Hasonló stabilitásnövekedést az EC peptidben egy további aszparaginsav koordinációban való részvétele jelentheti.

A His-t nem tartalmazó monokomplexek stabilitási állandóinak összehasonlítását követően nagyon hasonló a $\lg K \sim$ 11,6-11,8 körüli érték, kivéve a három 10-tagú, hisztidin aminosavakat is tartalmazó peptidet. Különösen kiemelkedő azonban az AcEEGCCHGHHE- $\mathrm{NH}_{2}$ peptidre meghatározott stabilitási állandó, amely ligandumban a tiolcsoportok bázicitása is a legnagyobb. A hisztidint nem tartalmazó ligandumok $\mathrm{Cd}^{2+}-$ komplexeivel szembeni jelentős extra stabilitás a tiolcsoportok bázicitásán túl minden bizonnyal a ciszteinek peptidláncbeli elhelyezkedésének (CC szekvencia) és a hisztidineknek köszönhető. A szerzők ezt a lehetőséget nem említik munkájukban, azonban joggal feltételezhetjük, hogy a három peptidben nem csak a tiolátcsoportok szolgálnak donorcsoportként a fémion megkötésében. 
5.2.1.1.2. táblázat: $\mathrm{Az}$ általunk vizsgált peptidek $\mathrm{Zn}^{2+/} \mathrm{Cd}^{2+}-$ komplexeinek képződési állandói összehasonlítva két ciszteint tartalmazó $\mathrm{Zn}^{2+/} \mathrm{Cd}^{2+}-$ komplexeinek állandóival

\begin{tabular}{|c|c|c|c|c|c|}
\hline Ligandum & $\lg \boldsymbol{\beta}_{\mathrm{ZnL}}$ & $\lg \beta_{\mathrm{ZnL}_{2}}$ & $\lg \beta_{\mathrm{CdL}}$ & $\lg \beta_{\mathrm{CdL}_{2}}$ & Hivatkozás \\
\hline Ac-CC-NH ${ }_{2}$ & - & 17,63 & - & 20,71 & [109] \\
\hline Ac-CGC-NH 2 & - & 18,81 & - & 22,30 & [104] \\
\hline Ac-CPCP-NH ${ }_{2}$ & - & 18,81 & 11,82 & 21,26 & [104] \\
\hline Ac-GSCCHTGNHD-NH ${ }_{2}$ & 11,75 & - & 14,26 & - & [109] \\
\hline Ac-EEGCCHGHHE-NH ${ }_{2}$ & 13,15 & - & 15,83 & - & [109] \\
\hline Ac-CCSTSDSHHQ-NH ${ }_{2}$ & 10,90 & - & 13,66 & - & [109] \\
\hline 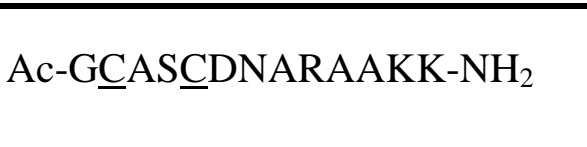 & $\lg K_{\mathrm{ZnHL}}=9,21^{\mathrm{a}}$ & $\begin{array}{l}\lg \beta_{\mathrm{ZnHL}}=20,11 \\
\mathrm{p} K_{\mathrm{Lys}}=10,90\end{array}$ & $\lg K_{\mathrm{CdHL}}=11,76^{\mathrm{a}}$ & $\begin{array}{l}\lg \beta_{\mathrm{CdHL}}=22,24 \\
\mathrm{p} K_{\mathrm{Lys}}=10,48\end{array}$ & {$[108]$} \\
\hline Ac-SCPGDQGSDCPI-NH 2 (PP) & 9,79 & 14,57 & 11,60 & 17,81 & Jelen munka \\
\hline Ac-SCPGDQGSDCSI-NH 2 (PS) & 9,93 & 14,72 & 11,61 & 17,70 & Jelen munka \\
\hline Ac-SCHGDQGSDCSI-NH 2 (HS) & 10,54 & 14,77 & 11,78 & 18,23 & Jelen munka \\
\hline Ac-ACPGDDSADCPI-NH $2(\mathbf{E C})$ & 10,56 & 14,82 & 12,24 & 17,62 & Jelen munka \\
\hline
\end{tabular}

${ }^{\mathrm{a}} \lg K_{\mathrm{ZnHL} / \mathrm{CdHL}}=\lg \beta_{\mathrm{ZnHL} / \mathrm{CdHL}}-\mathrm{p} K_{\mathrm{Lys}}$ 
Komplexeinket ${ }^{1} \mathrm{H}$ NMR spektroszkópiával is vizsgáltuk, hogy a koordinálódó donorcsoportok azonosításán túl, a ligandum szerkezeti és dinamikai sajátságairól is kapjunk információt. A fémiont is tartalmazó rendszerek vizsgálata során $\mathrm{pH}$-függő sorozatokat vettünk fel 1:1 fémion:ligandum arány mellett (5.2.1.1.3. ábra).
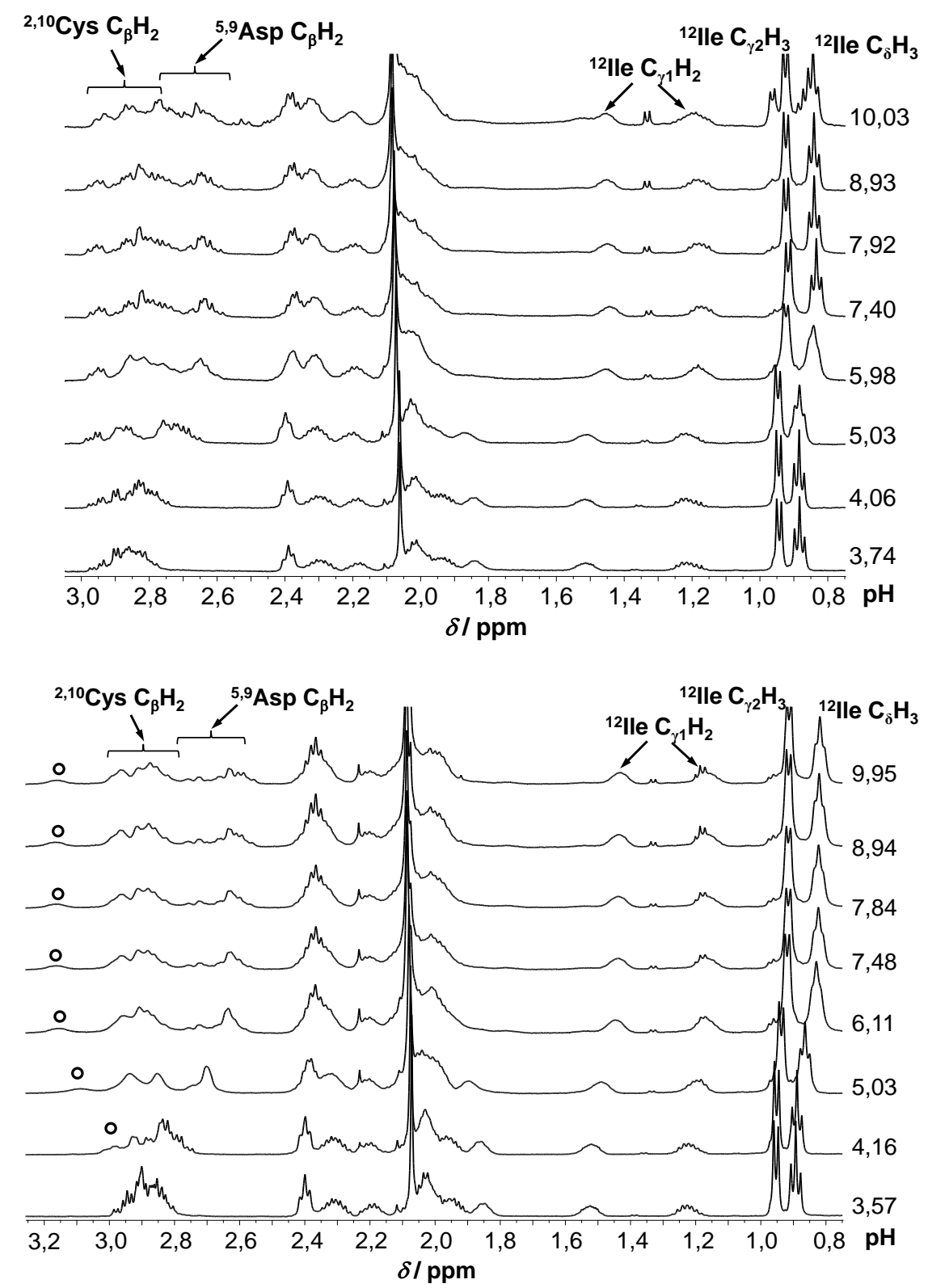

5.2.1.1.3. ábra: $\mathrm{A} \mathrm{Zn}^{2+}-\mathbf{P P}$ (fent) és a $\mathrm{Cd}^{2+}-\mathbf{P P}$ (lent) $1: 1$ fémion:ligandum arányú rendszerek pH-függő ${ }^{1} \mathrm{H}$ NMR spektrumainak részlete az alifás hidrogének tartományában $\left(c_{\mathbf{P P}}=1,3 \times 10^{-3} \mathrm{M}, \mathrm{H}_{2} \mathrm{O} / \mathrm{D}_{2} \mathrm{O}=90 / 10 \% \mathrm{v} / \mathrm{v}, I=0,1 \mathrm{M} \mathrm{NaClO}_{4}, T=298 \mathrm{~K}\right)$

Az ekvimoláris összetételű rendszerben $\mathrm{pH}=3,5-5$ tartományban az Asp $\mathrm{C}_{\beta} \mathrm{H}_{2}$ jelek a szabad ligandumnál tapasztaltakhoz hasonlóan eltolódnak a nagyobb terek irányába (F9. ábra), tehát elmondható, hogy a karboxilcsoportok koordinációban való részvétele nem jelentős. $\mathrm{pH} \sim 5$ felett a jelek mindkét fémion esetén kissé kiszélesedtek, ami az eddigi 
eredményekkel összhangban a komplexképződés megindulását jelzi. Ekkor a rendszerben ugyanis többféle részecske is jelen van (lásd 5.2.1.1.1. ábra), melyek között az NMR időskálájához képest (ms-s) közepes sebességü csere játszódik le. Érdemes megfigyelni, hogy a spektrumon $\mathrm{pH}>$ 7,5 jelentős változás nem tapasztalható. Ez szintén összhangban van az eloszlási diagrammal (5.2.1.1.1. ábra) és az A vs. pH görbével (5.2.1.1.2. ábra) miszerint egyetlen domináns részecske van jelen az oldatban.

Ha pH 7,5-nél összevetjük a monokomplexekhez tartozó spektrumokat a szabad ligandum azonos spektrumrészletével, szembetűnő, hogy az izoleucin egységhez tartozó protonok rezonanciái alacsonyabb ppm értékek felé tolódtak, ami egyértelmü jele, hogy ezen a pH-n az összes ligandum kötött állapotban van. Továbbá a $\mathrm{Zn}^{2+}$-ionok jelenlétében a $\mathrm{C}_{\beta} \mathrm{H}_{2}$ jelek kevésbé szélesedtek ki, mint a $\mathrm{Cd}^{2+}$-komplexek esetén (5.2.1.1.3. ábra).

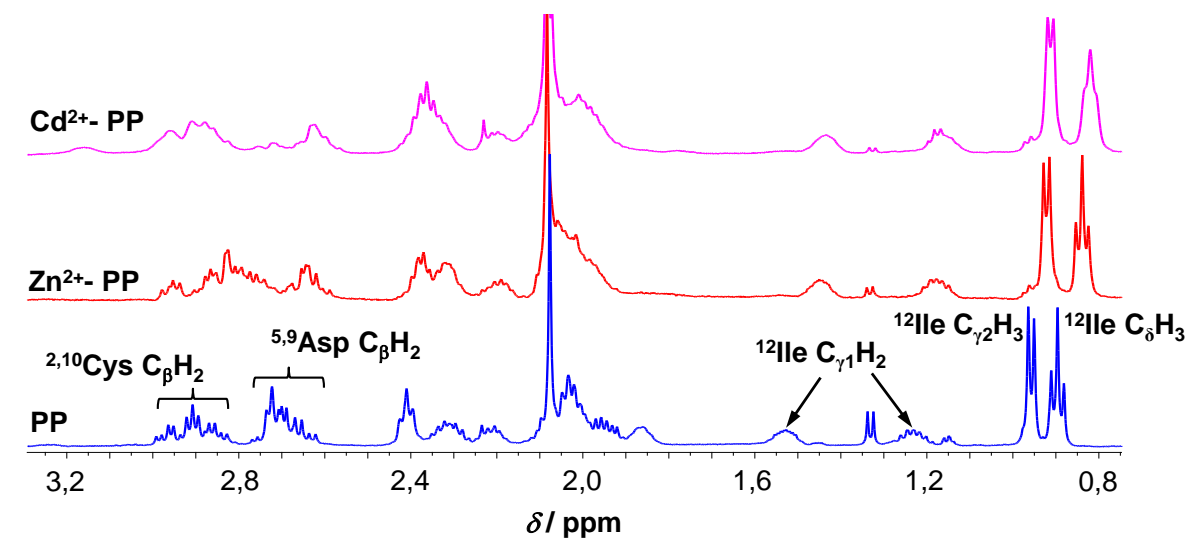

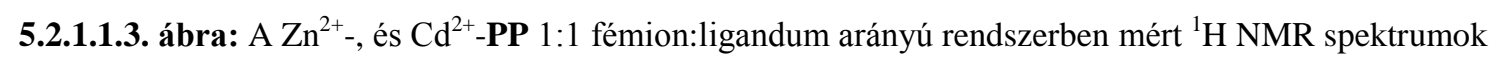
részlete az alifás hidrogének tartományában $\left(c_{\mathbf{P P}}=1,3 \times 10^{-3} \mathrm{M}, \mathrm{H}_{2} \mathrm{O} / \mathrm{D}_{2} \mathrm{O}=90 / 10 \% \mathrm{v} / \mathrm{v}, I=0,1 \mathrm{M} \mathrm{NaClO}_{4}\right.$, $\mathrm{pH} \sim 7,5, T=298 \mathrm{~K})$

A CdL és ZnL komplex spektrumain tapasztalt eltérő vonalszélesedés a ligandum konformációs izomerjei közötti cseresebesség különbségét mutatja. A $\mathrm{Cd}^{2+}-$ komplexben ez a csere lassabb, mint a $\mathrm{Zn}^{2+}$-komplexben. A Cys és Asp $\mathrm{C}_{\beta} \mathrm{H}_{2}$ rezonanciákat a szabad ligandummal összevetve kémiai eltolódásukban különbség tapasztalható.

A potenciametriai és UV mérésekkel jó egyezésben az ${ }^{1} \mathrm{H}$ NMR is megerősítette a Cys-tiolátok kötődését az ML komplexekben, továbbá az Asp $\mathrm{C}_{\beta} \mathrm{H}_{2}$ jeleinek szabad ligandumtól való eltéréséből $\mathrm{pH} \sim 7,5$ felett karboxilcsoportok koordinációja is feltételezhető. A PS peptid esetén hasonló spektrális változásokat tapasztaltunk (F32-F33. ábrák). 
A ligandumok fémionok hatására bekövetkező konformáció-változását a ZnL, illetve CdL törzskomplexek kialakulása során (SR)CD spektroszkópiával követtük. Az 5.2.1.1.4. ábrán szaggatott vonallal jelöltem a szabad $\mathbf{P P} \mathrm{pH}=10,3$-nál mért spektrumát, ahol az ML törzskomplexekhez hasonlóan a peptid minden potenciális donorcsoportja deprotonált formában van.

Ehhez hasonlítva a ZnL és CdL komplexek spektrumain szignifikáns eltérést tapasztaltunk. A két komplex spektrumát egymáshoz hasonlítva kismértékü különbség figyelhető meg a $\lambda \sim$ 195-200 nm tartományban mért ellipticitásokon, azonban összességében mindkét komplexben nagyon hasonló konformáció-eloszlásról beszélhetünk (5.2.1.1.4. ábra).

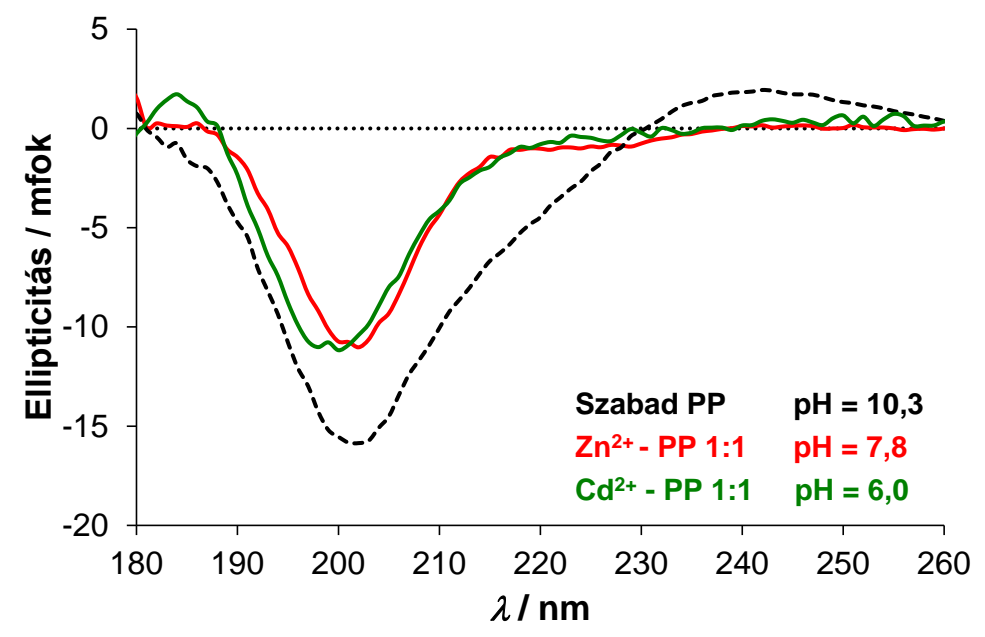

5.2.1.1.4. ábra: $\mathrm{Az}$ CdL illetve $\mathrm{ZnL}$ komplexek képződési maximumánál felvett $\mathrm{CD}$ spektrumok összehasonlítása a szabad ligandum spektrumával $\left(c_{\mathbf{P P}}=1,0 \times 10^{-4} \mathrm{M}, I=0,1 \mathrm{M} \mathrm{NaClO}_{4}, l=1 \mathrm{~mm}, T=298 \mathrm{~K}\right)$

\subsubsection{A PP ligandumot feleslegben tartalmazó rendszerek vizsgálata}

Annak eldöntésére, hogy a $\mathrm{Zn}^{2+}$-, és $\mathrm{Cd}^{2+}$-ionokhoz két ligandum kötödésére van-e lehetőség, ligandumfelesleg mellett is végeztünk potenciometriás titrálásokat. Míg savas körülmények között $(\mathrm{pH}<7)$ az egy ekvivalens fémiont tartalmazó rendszerhez hasonlított a részecskék eloszlása (5.2.1.2.1. ábra), addig semleges és lúgos $\mathrm{pH}$ tartományban további komplexek feltételezésére volt szükség a titrálási görbék illesztéséhez. A pH-potenciometriás adatok kiértékelése során számolt bruttó stabilitási állandókat és néhány származtatott értéket az 5.2.1.1.1. táblázat foglalja össze.

$\mathrm{A} \mathrm{Zn}^{2+}$-PP 0,5:1 fémion:ligandum arányú rendszerben a $\mathrm{pH} \sim$ 6,5-nél uralkodó $\mathrm{ZnL}$ részecske kialakulását követően egy újabb ligandum koordinációjával a $\mathrm{ZnHL}_{2}$ összetételü protonált biszkomplex képződését figyelhetjük meg. Ez a pH további növelésével deprotonálódik, és a rendszerben megjelenik a $\mathrm{ZnL}_{2}$ részecske (5.2.1.2.1. ábra). 

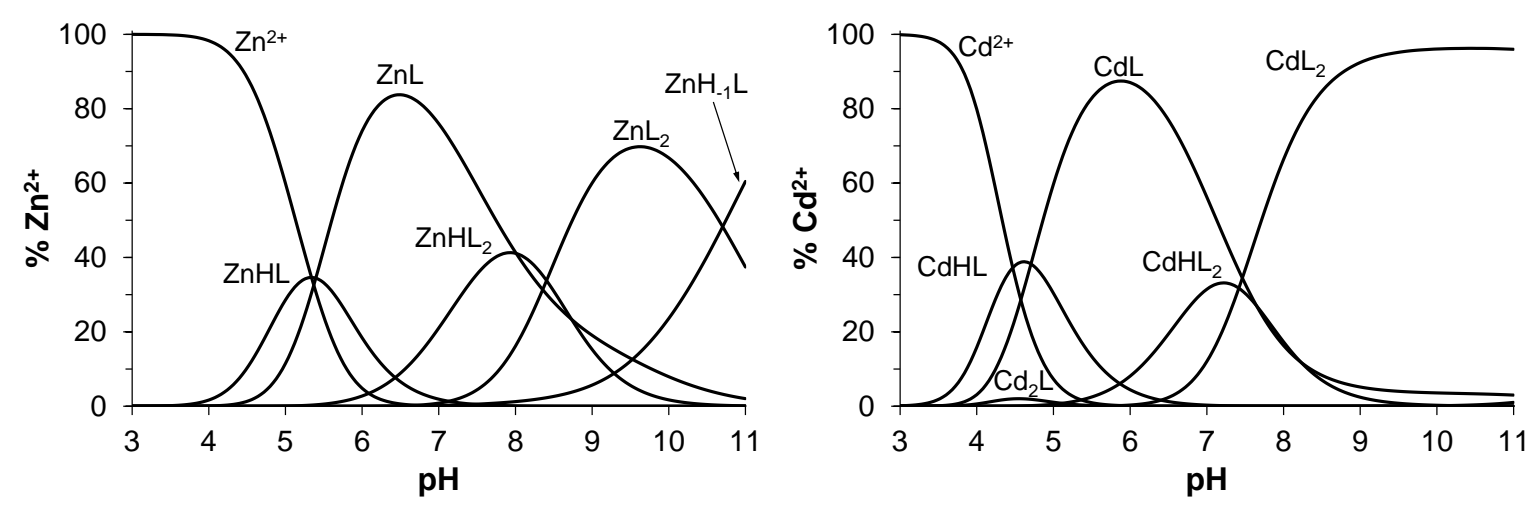

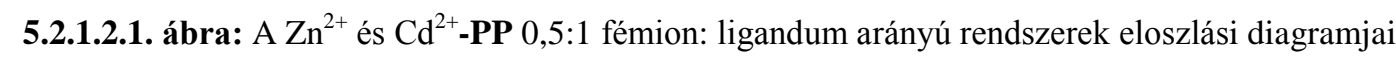
$\left(c_{\mathbf{P P}}=1,0 \times 10^{-3} \mathrm{M}, I=0,1 \mathrm{M} \mathrm{NaClO}_{4}, T=298 \mathrm{~K}\right)$

A reakció $\mathrm{p} K_{\mathrm{s}}=8,41$ értékkel jellemezhetö, ami közel áll a szabad ligandumban található tiolcsoportok $\mathrm{p} K_{\mathrm{s}}$ értékeihez (5.1.2.1. táblázat).

Ligandumfelesleg mellett $\mathrm{Cd}^{2+}$-ionok jelenlétében a $\mathrm{CdHL}_{2}$ részecske képződése már $\mathrm{pH}=$ 5-től megkezdődik, majd deprotonálódásával a $\mathrm{CdL}_{2}$ törzskomplex válik uralkodóvá (5.2.1.2.1. ábra). Az átalakulás $\mathrm{p} K_{\mathrm{s}}=7,41$ értékkel jellemezhető, ami egy $\mathrm{pH}$ egységgel alacsonyabb a szabad ligandumban található tiolcsoportok $\mathrm{p} K_{\mathrm{s}}$ értékeinél (5.1.2.1. táblázat). Azt, hogy második ligandum mindkét tiolátcsoportja koordinálódik-e a $\mathrm{Zn}^{2+}$-ionhoz, vagy csak egy nem kötődő tiolcsoport deprotonálódása játszódik le $\mathrm{pH}=7-10$ között, $\mathrm{pH}$-metriás adatok alapján nem állapítható meg egyértelmüen, azonban a $\mathrm{CdL}_{2}$ komplexben a második ligandum mindkét tiolcsoportja részt vehet a koordinációban.

A $\mathrm{ZnL}_{2}$ és $\mathrm{CdL}_{2}$ komplexek stabilitása közötti különbség szintén $\mathrm{Cd}^{2+}$-ionok szoftabb karakterében keresendő (5.2.1.1.2. táblázat). Azonban a biszkomplexek stabilitását (illetve a második ligandum kötődéséhez rendelhető állandókat) a monokomplexekkel összehasonlítva mindkét esetben megfigyeltük, hogy az $\mathrm{ML}_{2}$ komplexek kialakulását jellemző $\lg K_{2}$ érték $\left(\lg K_{2}=\lg \beta_{\mathrm{ML}_{2}}-\lg \beta_{\mathrm{ML}}\right)$ több nagyságrenddel kisebb $\left(\mathrm{Zn}^{2+}\right.$-jelenlétében $\lg K_{2}=4,80$ illetve $\mathrm{Cd}^{2+}$-jelenlétében $\left.\lg K_{2}=6,21\right)$, mint az ML komplex stabilitási állandója (5.2.1.1.1. táblázat). A legegyszerübb két ciszteint tartalmazó rövid peptidek, mint az Ac-CC- $\mathrm{NH}_{2}$; Ac-CGC- $\mathrm{NH}_{2}$ illetve az Ac-CPCP- $\mathrm{NH}_{2}$ méretükből adódóan főként biszkomplexeket képeznek a $\mathrm{Zn}^{2+}$-, és $\mathrm{Cd}^{2+}$-ionokkal. Általánosan elmondható, hogy míg a kisméretü, di-, tri-, és tetrapeptidek nagy stabilitású $\mathrm{ML}_{2}\left\{4 \times \mathrm{S}^{-}\right\}$típusú komplexeket képeznek $\mathrm{Zn}^{2+}$, és $\mathrm{Cd}^{2+}-$ ionokal, addig az általunk vizsgált dodekapeptideknél a biszkomplexek képződése nem kedvezményezett a fellépő sztérikus okok/elektrosztatikus taszítás miatt.

Míg a $\mathrm{Cd}^{2+}$-ionokat tartalmazó rendszerekben a biszkomplexek bázikus körülmények között is stabilisak, addig a $\mathrm{ZnL}_{2}$ részecske a $\mathrm{pH}$ növelésének hatására hidrolizál $\mathrm{ZnH}_{-1} \mathrm{~L}$ monokomplexet (ZnL részecskéhez koordinált víz deprotonálódásával képződő komplex, 
lásd 5.2.1.1 fejezet) és szabad ligandumot eredményezve (lásd 5.2.1.2.1. ábra). Ennek hajtóereje az lehet, hogy lúgos körülmények között a hidroxid-ionok nagy koncentrációja hatására a hidrolízis-részecske képződése kedvezményezettebb a második ligandum tiolcsoportjainak bekötődéséhez képest.

Ligandumfelesleg jelenlétben is végeztünk UV spektroszkópiai méréseket, hogy követhessük a tiolcsoportok fémion-koordinációban való részvételét (5.2.1.2.2. ábra).
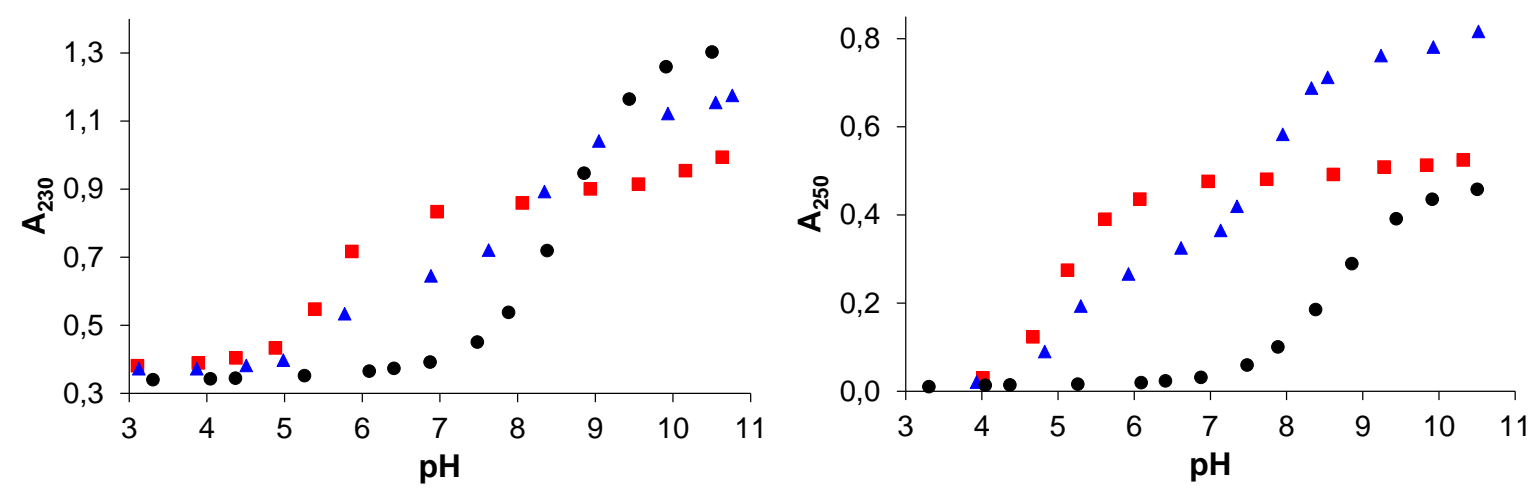

5.2.1.2.2. ábra: A különbözö fémion: ligandum arányú rendszerek $\mathrm{Zn}^{2+}-\mathbf{P P}$ (bal) és a $C d^{2+}-\mathbf{P P}$ (jobb) $\mathrm{A} v s$. $\mathrm{pH}$ görbéi összehasonlítva a szabad ligandummal. •: Szabad PP, $\mathbf{\Lambda}: \mathrm{Zn}^{2+} / \mathrm{Cd}^{2+}-\mathbf{P P}$ 0,5:1, $\mathbf{\square}: \mathrm{Zn}^{2+} / \mathrm{Cd}^{2+}-\mathbf{P P} 1: 1$ $\left(c_{\mathbf{P P}}=1,0 \times 10^{-4} \mathrm{M}, I=0,1 \mathrm{M} \mathrm{NaClO}_{4}, l=10 \mathrm{~mm}, T=298 \mathrm{~K}\right)$

A $\mathrm{Zn}^{2+}$-PP rendszerben a tiolát-fémion töltésátviteli sávokat vizsgálva az abszorbancia-változás jól követi a ZnHL és ZnL részecskék kialakulását. Az abszorbancianövekedés üteme ellentétben az ekvimoláris összetételü mintával, csak egy szűk pH tartományban, a ZnL komplexek képződési maximuma környékén lassul le. pH 7 felett párhuzamosan a szabad ligandumnál tapasztalt változással - az abszorbancia ismét nő, ami további tiolát-koordinációt jelez. Azonban fontos megjegyezni, hogy ugyan a potenciometriás mérési körülmények között $\left(\mathrm{c}_{\mathbf{P P}}=1,0 \times 10^{-3} \mathrm{M}\right)$ számolt eloszlási diagramokon $\mathrm{pH}=9$ körül a fémionok több mint $60 \%$-a $\mathrm{ZnHL}_{2} / \mathrm{ZnL}_{2}$ komplexben van (5.2.1.2.1. ábra), addig az UV mérési körülmények mellett $\left(\mathrm{c}_{\mathbf{P P}}=1,0 \times 10^{-4} \mathrm{M}\right) \mathrm{a}$ biszkomplexek mennyisége jóval csekélyebb (F20. ábra). Továbbá ebben a pH tartományban a biszkomplexek disszociációja (szabad ligandummá és $\mathrm{ZnH}_{-1} \mathrm{~L}$ részecskévé) is elindult, ami tovább nehezíti a $\mathrm{ZnL}_{2}$ részecske létezésének bizonyítását.

A $\mathrm{Cd}^{2+}$-PP 0,5:1 rendszerben az abszorbancia-változás a semleges pH környékéig (5.2.1.2.2. ábra) összhangban van a monokomplexek képződésével (5.2.1.2.1. ábra). Egy keskeny plató után $(\mathrm{pH} \sim$ 6-7,2 között) újabb intenzív abszorbancia emelkedés figyelhető meg, amely a szabad ligandumhoz képest közel egy pH-egységgel kisebb pH-n tapasztalható. Ez a potenciometriás eredményekkel együtt, egyértelmüen igazolja a biszkomplexek képződését. 
A két lépcsőben megfigyelt abszorbancia változás mértéke közel azonos, ami alátámasztja, hogy $\mathrm{CdL}_{2}$ komplexben $\left\{4 \times \mathrm{S}^{-}\right\}$típusú koordinációs környezetet alakít ki a két ligandum a $\mathrm{Cd}^{2+}$-ion körül. Négy tiolátcsoport koordinációját már semleges $\mathrm{pH}-\mathrm{n}$ is tapasztalták rövid, két Cys tartalmú peptidekben, azonban ott a ciszteineket csak egy aminosav választotta el egymástól [104]. Továbbá a $\mathrm{Cd}^{2+}-\mathrm{PC} 2$ komplexekben is $\left\{4 \times \mathrm{S}^{-}\right\}$ típusú kötődést figyelték meg[91].

${ }^{1} \mathrm{H}$ NMR-rel a potenciális donorcsoportokhoz (Cys, Asp) tartozó $\mathrm{C}_{\beta} \mathrm{H}_{2}$ rezonanciák változása révén információt nyújt az $\mathrm{ML}_{2}$ komplex szerkezetéről, valamint a komplexekben lévő PP ligandum dinamikai sajátságáról is. $\mathrm{A} \mathrm{Zn}^{2+}$-PP $0,5: 1$ arányú rendszerben a fent említettek mellett érdemes megfigyelni az izoleucinhoz tartozó jelcsoportok (5.2.1.2.3. ábra) és közülük föként a $\mathrm{C}_{\gamma 1} \mathrm{H}_{2}$ rezonanciáinak változását (०) is, melyek alacsony $\mathrm{pH}-\mathrm{n}$ ugyanolyan kémiai eltolódás értékeknél jelennek meg $(\delta=1,51 \mathrm{ppm})$, mint a szabad ligandum hasonló pH-jú spektrumain (5.2.1.1.3. ábra).

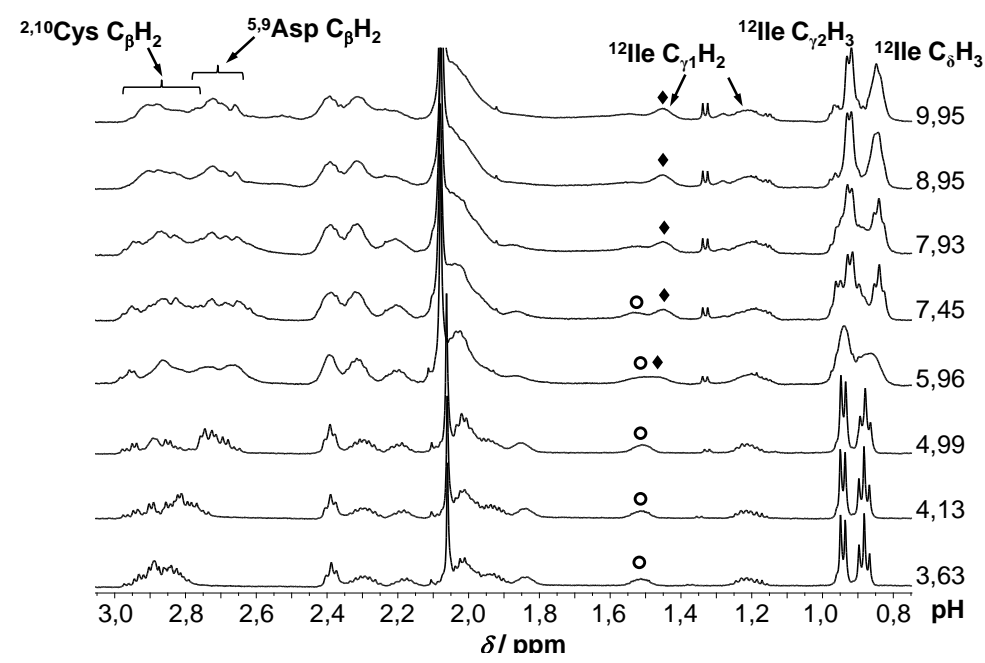

5.2.1.2.3. ábra: $\mathrm{A} \mathrm{Zn}^{2+}-\mathbf{P P} 0,5: 1$ fémion:ligandum arányú rendszerek $\mathrm{pH}$-függő ${ }^{1} \mathrm{H}$ NMR spektrumainak részlete az alifás hidrogének tartományában

$$
\left(c_{\mathbf{P P}}=1,3 \times 10^{-3} \mathrm{M}, \mathrm{H}_{2} \mathrm{O} / \mathrm{D}_{2} \mathrm{O}=90 / 10 \% \mathrm{v} / \mathrm{v}, I=0,1 \mathrm{M} \mathrm{NaClO}_{4}, T=298 \mathrm{~K}\right)
$$

Ez jó összhangban van az pH-potenciometriás eredményekkel, ugyanis $\mathrm{pH}=5$-ig ligandumfelesleg mellett is csak monokomplexek képződnek (5.2.1.2.1. ábra). $\mathrm{pH}=6$ felett azonban a szabad ligandumra jellemző csúcs mellett egy másik jel is megfigyelhető $\delta=1,45$ ppm értéknél (»), amely nagyon hasonló az 1:1 arányú rendszerben tapasztaltakhoz (5.2.1.1.3. ábra). A sztöchiometriai aránynak megfelelően a ZnL összetételü komplex $100 \%$ os jelenléte esetén két, egymással közel azonos intenzitású csúcsot kellene látnunk $\left(\mathrm{Zn}^{2+}\right.$ ionhoz kötött ligandum, valamint a szabad PP izoleucinjának megfelelő jele), amennyiben a kötött és a szabad ligandum forma között lassú csere megy végbe. Abban az esetben pedig, ha gyors csere játszódik le, a két jel átlagának kellene a ${ }^{1} \mathrm{H}-\mathrm{NMR}$ spektrumokon 
megjelennie. Ezzel szemben a pH-t növelve a szabad ligandumhoz hasonló jel $(\delta=1,51$ ppm) intenzitása csökken, ami egy újabb ligandum-fogyasztó folyamatot jelez.

Ez megerösíti azt a feltételezést, hogy ligandumfelesleg esetén biszkomplexek is képződnek, ami az eloszlási diagramok alapján $\mathrm{pH} \sim 6$ felett történik meg. A biszkomplexek képződésével párhuzamosan a $\mathrm{C}_{\beta} \mathrm{H}_{2}$ jelek kiszélesedése jelentősebb, összehasonlítva az 1:1 arányú rendszerrel. Mivel $\mathrm{pH}=6$ felett több részecske is egyidőben van jelen $(\mathrm{a} \mathrm{ZnL}$ mellett szabad PP, majd $\mathrm{ZnHL}_{2}, \mathrm{ZnL}_{2}$ valamint magasabb $\mathrm{pH}-\mathrm{n} \mathrm{ZnH}_{-1} \mathrm{~L}$ (5.2.1.2.1. ábra)), ezen részecskék közötti ligandum-cseresebesség lassulása okozhatja a vonalszélesedést. Ezt jól szemlélteti a pH 9-nél mért spektrumok összehasonlítása is (5.2.1.2.4. ábra).

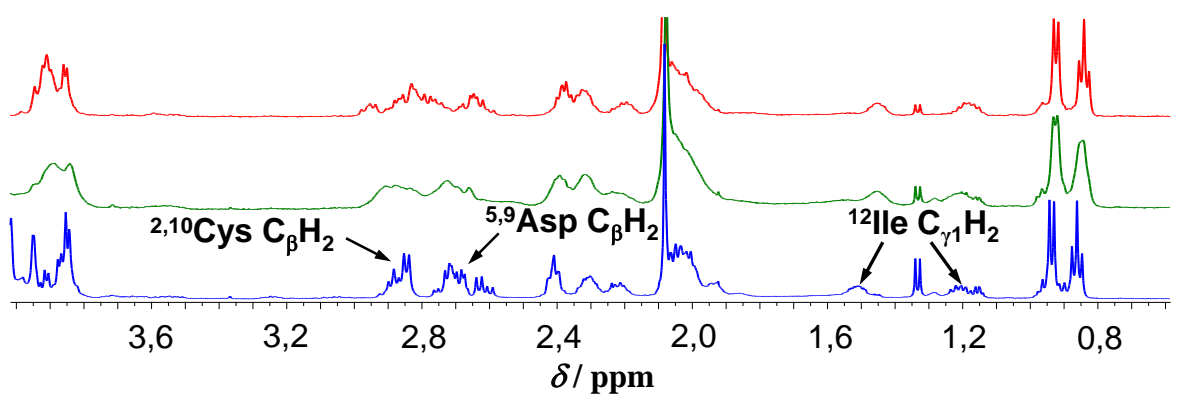

5.2.1.2.4. ábra: $A Z^{2+}-P P$ rendszerben felvett ${ }^{1} H$ NMR spektrumok részlete alifás hidrogének tartományában Kék: szabad PP, Zöld: $Z^{2+}$-PP 0,5:1, Piros: $Z^{2+}{ }^{2+}$ PP 1:1

$\left(c_{\mathbf{P P}}=1,3 \times 10^{-3} \mathrm{M}, \mathrm{H}_{2} \mathrm{O} / \mathrm{D}_{2} \mathrm{O}=90 / 10 \% \mathrm{v} / \mathrm{v}, I=0,1 \mathrm{M} \mathrm{NaClO}_{4}, \mathrm{pH} \sim 9,0, T=298 \mathrm{~K}\right.$

$\mathrm{Cd}^{2+}$-ionok jelenlétében a PP ligandumot kétszeres mennyiségben alkalmazva a spektrumok erösen savas $\mathrm{pH}$-tól körülbelül $\mathrm{pH}=6$-ig nagyon hasonlóak ahhoz, amit 1:1 (fémion-ligandum) aránynál tapasztaltaltunk (5.2.1.2.5. ábra).

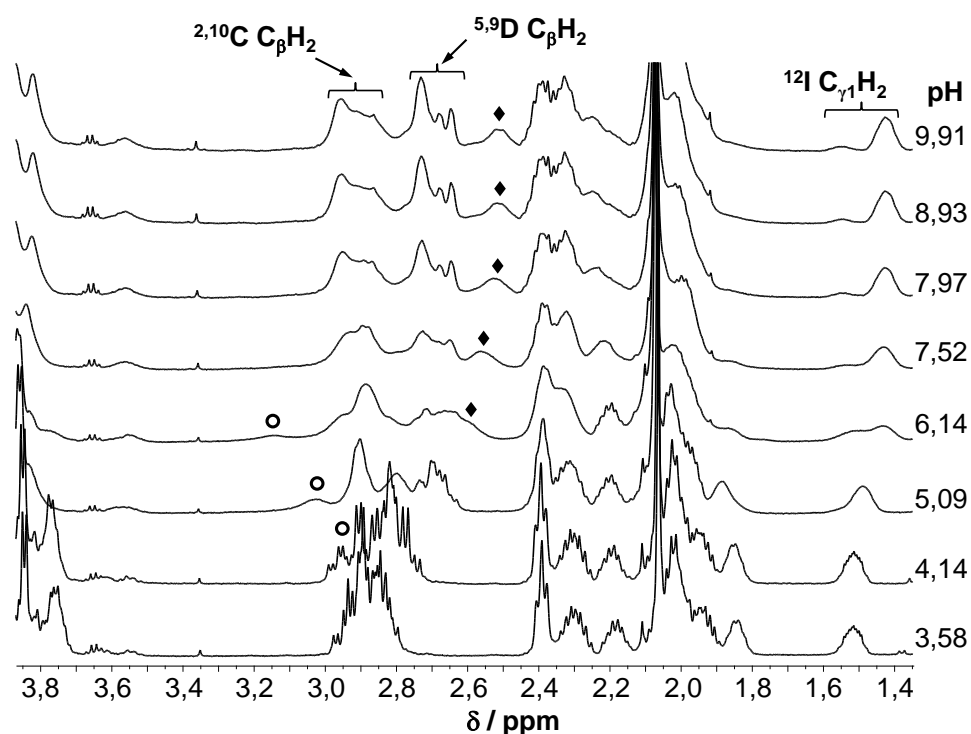

5.2.1.2.5. ábra: $\mathrm{A} \mathrm{Cd}^{2+}+\mathbf{P P}=0,5: 1$ fémion ligandum arányú rendszer $\mathrm{pH}$-függő ${ }^{1} \mathrm{H}$ NMR spektrumainak részlete az alifás hidrogének tartományában $\left(c_{\mathbf{P P}}=1,3 \times 10^{-3} \mathrm{M}, \mathrm{H}_{2} \mathrm{O} / \mathrm{D}_{2} \mathrm{O}=90 / 10 \% \mathrm{v} / \mathrm{v}, I=0,1 \mathrm{M} \mathrm{NaClO}_{4}, T=298 \mathrm{~K}\right)$ 
Az egyik, ciszteinhez rendelhető csúcs $\mathrm{pH} \sim 6$-ra az alacsonyabb terek irányába tolódik $(\delta=$ 3,15 ppm;○). Ez nagyon hasonló ahhoz, amit az egy ekvivalens $\mathrm{Cd}^{2+}$-iont tartalmazó rendszernél figyeltünk meg (5.2.1.1.3. ábra). Azonban az 1:1 arányú spektrumsorozattal ellentétben a pH további növelésével ez a csúcs fokozatosan eltűnik, illetve ezzel párhuzamosan a $\delta=2,6-2,5$ ppm között egy széles sáv jelenik meg ( $\bullet$. Ez a $\mathrm{C}_{\beta} \mathrm{H}_{2}$ jel a szabad ligandum, és az ekvimoláris rendszer Cys, illetve Asp $\mathrm{C}_{\beta} \mathrm{H}_{2}$ rezonanciáihoz képest is kisebb kémiai eltolódású, ami egy új kémiai környezetben lévő ligandumra utal. Ez az eloszlási diagram (5.2.1.2.1. ábra) és az UV-mérések (5.2.1.2.2. ábra) alapján is a semleges $\mathrm{pH}$ felett képződő biszkomplex lehet. Az új részecske megjelenése még egyértelmübb a bázikus körülmények mellett mért spektrumon (5.2.1.2.6. ábra), ahol a koordinálódó donorcsoportot nem tartalmazó aminosavakhoz tartozó rezonanciák is jobban feloldottak, mint kisebb pH-n.

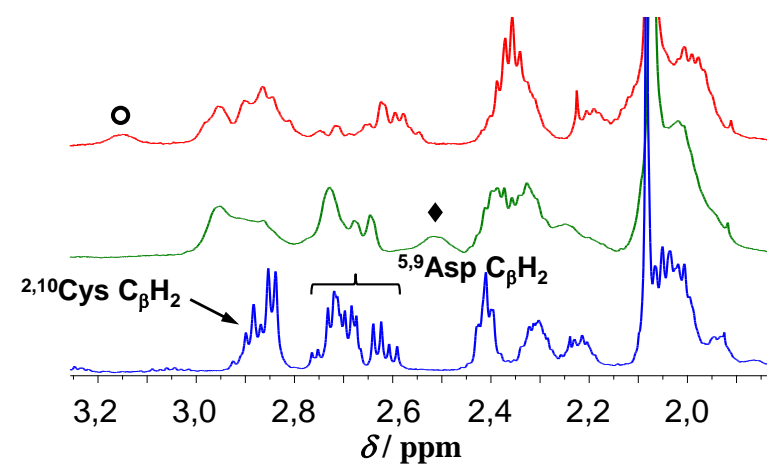

5.2.1.2.6. ábra: $\mathrm{A} \mathrm{Cd}{ }^{2+}-\mathrm{PP}$ rendszerben felvett ${ }^{1} \mathrm{H}$ NMR spektrumok részlete az alifás hidrogének tartományában. Kék: szabad PP, Zöld: $\mathrm{Cd}^{2+}+\mathbf{P P}$ 0,5:1, Piros: $\mathrm{Cd}^{2+}$-PP 1:1 $\left(c_{\mathbf{P P}}=1,3 \times 10^{-3} \mathrm{M}, \mathrm{H}_{2} \mathrm{O} / \mathrm{D}_{2} \mathrm{O}=90 / 10 \% \mathrm{v} / \mathrm{v}, I=0,1 \mathrm{M} \mathrm{NaClO}_{4}, \mathrm{pH} \sim 9,0, T=298 \mathrm{~K}\right)$

A PS ligandummal hasonló folyamatok lejátszódását tapasztaltuk. Savas körülmények között $(\mathrm{pH}<6)$ elsősorban monokomplexek $(\mathrm{ZnHL}, \mathrm{ZnL}$ valamint CdHL és $\mathrm{CdL})$, míg lúgos közegben biszkomplexek $\left(\mathrm{ZnHL}_{2}, \mathrm{ZnL}_{2}\right.$ valamint $\mathrm{CdHL}_{2}$, és $\left.\mathrm{CdL}_{2}\right)$ képződnek (F21., F24. és F35. ábrák). A PP peptidhez hasonlóan a PS ligandummal is tapasztaltuk $\mathrm{pH}=9$ felett a $\mathrm{ZnL}_{2}$ részecske disszociációját $\mathrm{ZnH}_{-1} \mathrm{~L}$ részecskévé és szabad ligandummá. Az EC peptiddel azonban az ekvimoláris rendszerhez hasonlóan, lúgos körülmények között szintén egy $\mathrm{M}_{2} \mathrm{H}_{-1} \mathrm{~L}_{2}$ összetételü részecske képződését kellett feltételeznünk a rendszer leírásához (F29. ábra). Az EC ligandumfelesleg mellett felvett UV spektrumok nagyon hasonlóak voltak a PP peptidnél tapasztaltakhoz (F30-F31. ábra). Az NMR spektrumok a jelentős vonalszélesedés miatt további információval nem szolgáltak (F38-F39. ábra). 


\subsubsection{A hisztidint is tartalmazó HS ligandum $\mathrm{Zn}^{2+}-$ és $\mathrm{Cd}^{2+}-$ komplexei}

A PS peptidbe egy hisztidint beépítve olyan ligandum állítható elő, amely jó modellvegyülete lehet a kétértékü fémionok érzékelésében fontos szerepet játszó transzkripciós fehérjéknek (pl.: ZntR). Ezért a továbbiakban megvizsgáltuk, hogy a hisztidintartalmú HS peptid fémkomplexeiben milyen szerkezeti, illetve stabilitási eltéréseket okoz az imidazolcsoport jelenléte.

\subsubsection{Az ekvimoláris $\mathrm{Zn}^{2+}$-, és $\mathrm{Cd}^{2+}$-iont tartalmazó rendszerek vizsgálata}

Egy ekvivalens fémion jelenlétében jelen esetben is a monokomplexek dominálnak (5.2.2.1.1. ábra). Az eloszlási diagramon megfigyelhető első uralkodó részecskék a CdHL, illetve ZnHL, amelyekben a HS két aszparaginsava mellett további két csoport deprotonálódott.
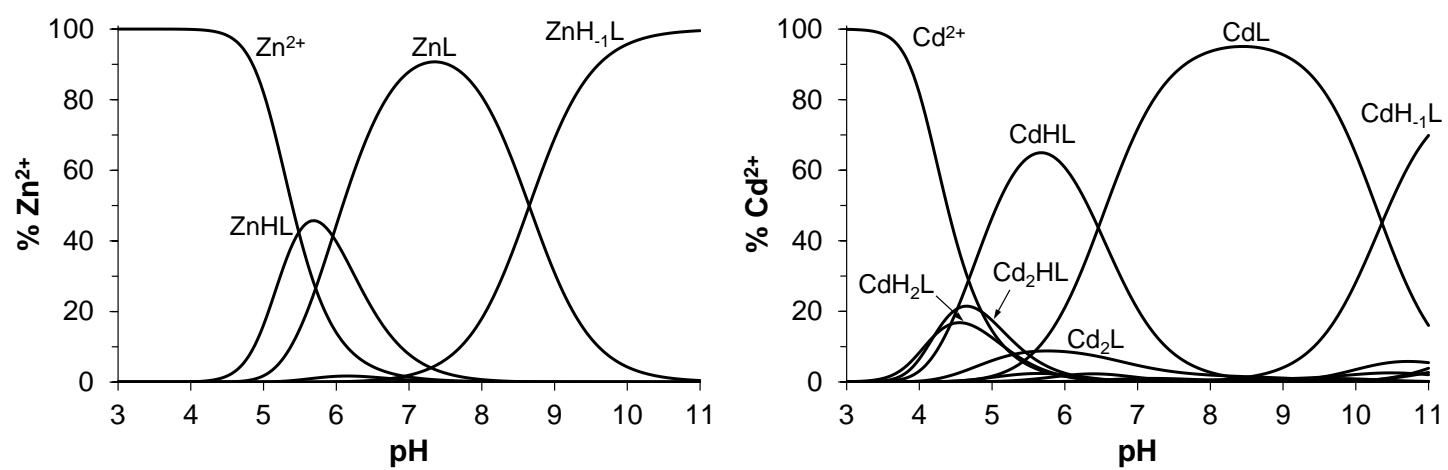

5.2.2.1.1. ábra: $\mathrm{A} \mathrm{Zn}^{2+}$ - és $\mathrm{Cd}^{2+}$-HS $1: 1$ fémion-ligandum arányú rendszerek eloszlási diagramjai

$$
\left(c_{\text {HS }}=1,0 \times 10^{-3} \mathrm{M}, I=0,1 \mathrm{M} \mathrm{NaClO}_{4}, T=298 \mathrm{~K}\right)
$$

A protonált monokomplexekben a Cys tiolcsoportok részvételét a koordinációban az UV spektrumokon, a tiolát $\rightarrow$ fémion töltésátviteli sáv megjelenésével tudjuk nyomon követni (F19. ábra). Amint az 5.2.2.1.2. ábra mutatja, a ciszteinek egy lépésben történő deprotonálódása $\mathrm{Cd}^{2+}$-ionok jelenlétében $\mathrm{pH} \sim 6$ 6-ra, míg $\mathrm{Zn}^{2+}$-ionok jelenlétében ennél több mint fél $\mathrm{pH}$ egységgel magasabbra tehetö.
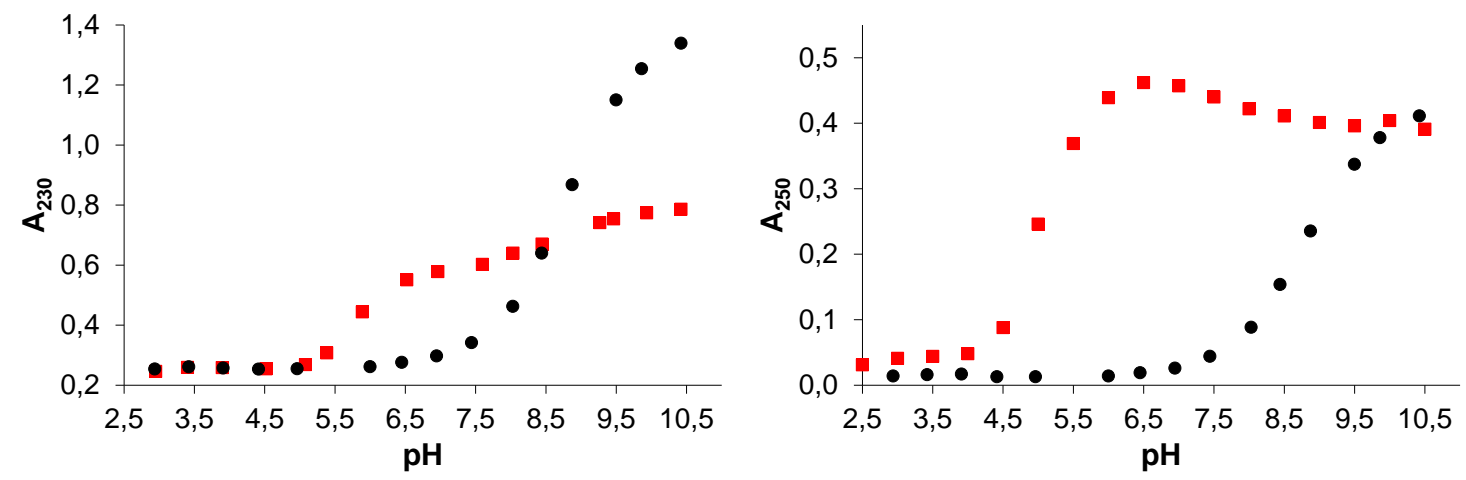

5.2.2.1.2. ábra: $\mathrm{Zn}^{2+}-\mathrm{HS}$ (bal) és a $\mathrm{Cd}^{2+}$-HS (jobb) $1: 1$ fémion:ligandum arányú rendszerek $\mathrm{A}$ vs. pH görbéje összehasonlítva a szabad ligandummal. •: Szabad HS, $\mathbf{~ : ~} \mathrm{Zn}^{2+} / \mathrm{Cd}^{2+}-\mathbf{H S} 1: 1\left(c_{\mathbf{H S}}=1,0 \times 10^{-4} \mathrm{M}, I=0,1 \mathrm{M}\right.$ $\left.\mathrm{NaClO}_{4}, l=10 \mathrm{~mm}, T=298 \mathrm{~K}\right)$ 
Az UV spektroszkópiás vizsgálatok eredményeit az eloszlási diagramokkal (F16. ábra) összevetve elmondhatjuk, hogy a CdHL komplexben a HS ligandum feltehetőleg $\left\{2 \times \mathrm{S}^{-}, 2 \times \mathrm{COO}^{-}\right\}$típusú koordinációt alakít ki, a Cys tiolátcsoportok és Asp karboxilátcsoportok részvételével. Ekvimoláris rendszerben Dorcak és munkatársai hasonló típusú koordinációt javasoltak $\mathrm{Cd}^{2+}-\mathrm{PC} 2$ komplexekre (lásd 3.4.3. fejezet) [91]. A ZnHL komplexben a pH-metriás és UV adatok alapján nem lehet egyértelműen megállapítani, hogy két tiolát vagy egy tiolát- és egy His imidazolcsoportja vesz-e részt a koordinációban.

A pH növelésével újabb deprotonálódási folyamat játszódik le, ami a hisztidint nem tartalmazó rendszerekhez hasonlóan, a CdL és $\mathrm{ZnL}$ törzskomplexek képződéséhez rendelhető, melyben a ligandum összes disszociábilis protonját elveszítette. A CdHL $\rightarrow \mathrm{CdL}$ és $\mathrm{ZnHL} \rightarrow \mathrm{ZnL}$ folyamatokat jellemző $\mathrm{p} K_{\mathrm{s}}$ értékek $\left(\mathrm{p} K_{\mathrm{ZnHL}}=5,95\right.$ és $\left.\mathrm{p} K_{\mathrm{CdHL}}=6,46\right)$ is jelentősen alacsonyabbak a szabad ligandum Cys alegységeinek $\mathrm{p} K_{\mathrm{s}}$ értékeinél (5.1.2.1. táblázat), azonban a $\mathrm{Cd}^{2+}$-komplexhez tartozó állandó közel esik a szabad ligandum His $\mathrm{p} K_{\mathrm{s}}$ értékéhez $\left(\mathrm{pK}_{\mathrm{s}}=6,53\right)$. Ez azt sugallhatja, hogy míg a $\mathrm{Zn}^{2+}$-ionok jelenlétében a His imidazolcsoport a fémionhoz már a ZnHL részecskében is koordinálhat, addig $\mathrm{Cd}^{2+}$-ionok esetén ez csak később következik be. Az UV eredmények alapján azonban a Cys alegységek tiolátcsoportjainak koordinációja a $\mathrm{ZnL}$ és a $\mathrm{CdL}$ részecskékben is bizonyított.

A $\mathrm{Cd}^{2+}$-HS komplex A vs. pH görbéje azonban kismértékü abszorbancia-csökkenést mutat párhuzamosan az eloszlási diagramon látható CdL komplex kialakulásával, ami a His imidazolcsoport koordinációja által indukált szerkezetváltozás hatása lehet. A törzskomplexeket az általunk vizsgált hisztidint nem tartalmazó peptidek ZnL és CdL komplexeinek stabilitásával összevetve (5.2.1.1.2. táblázat) szembetűnő a hisztidin extra stabilizáló hatása. Más hisztidintartalmú N-, és C-terminálisan is védett peptidek $\mathrm{Cd}^{2+}$-, és $\mathrm{Zn}^{2+}$-komplexeinek stabilitásától igaz elmarad, azonban azokban a két cisztein alegység mellett kettő, illetve három hisztidin is található, ami okozhatja a további stabilitásnövekedést.

Bázikus körülmények között újabb deprotonálódás történik, ami a $\mathrm{ZnH}_{-1} \mathrm{~L}_{\text {s }} \mathrm{CdH}_{-1} \mathrm{~L}$ összetételü komplexek megjelenéséhez vezet. $\mathrm{A} \mathrm{ZnL} \rightarrow \mathrm{ZnH}_{-1} \mathrm{~L}$ folyamatot jellemzö $\mathrm{p} K_{\mathrm{s}} \sim 8,65$ érték mintegy 1,7 logaritmus egységgel kisebb a $\mathrm{CdH}_{-1} \mathrm{~L}$ képződését jellemző értéknél, ami elsősorban a $\mathrm{Zn}^{2+}$-ion kisebb ionsugarával magyarázható. A koordinált víz deprotonálódása alacsonyabb $\mathrm{pH}-\mathrm{n}$ következik be, mint más, általunk vizsgált, de hisztidint nem tartalmazó peptidek $\mathrm{Zn}^{2+}$-, és $\mathrm{Cd}^{2+}$-hidroxo-komplexeiben. Az általunk javasolt $\left\{2 \times \mathrm{S}^{-}\right.$ $\left., \mathrm{N}_{\mathrm{im}}, \mathrm{H}_{2} \mathrm{O} / \mathrm{OH}^{-}\right\}$típusú koordinációt feltételeznek a ló máj alkohol-dehidrogenáz enzim aktív centrumában is, ahol a fémionhoz kötött $\mathrm{H}_{2} \mathrm{O}$ molekula deprotonálódásához rendelhető 
állandó az $\mathrm{Zn}^{2+}$-tartalmú natív fehérjében $\mathrm{p} K_{\mathrm{s}}=9,2$ [121], a $\mathrm{Cd}^{2+}$-tartalmúra pedig $\mathrm{p} K_{\mathrm{s}}=$ 11,0 [122]. Ezekhez képest az általunk vizsgált $\mathrm{Zn}^{2+}-\mathbf{H S}$ rendszerben alacsonyabb értéket kaptunk, ami alapján arra következtetünk, hogy a hisztidin jelenléte a HS peptidben $\mathrm{pH}=7$ felett jelentősen befolyásolja a fémionok koordinációs szféráját, valamint a komplex szerkezetét.

Az pH-metriás és UV spektroszkópiai vizsgálatok eredményeiből valószínüsítettük, hogy a HS peptid His imidazolcsoportja már a ZnHL részecskében is kötődik a fémionhoz. $\mathrm{Cd}^{2+}$-ionok jelenlétében azonban erre csak a $\mathrm{CdL}$ komplexben kerül sor. Ennek bizonyítására, valamint a fémionok a ligandum szerkezetére gyakorolt hatásának vizsgálatára ${ }^{1} \mathrm{H}$ NMR méréseket végeztünk. Savas körülmények között $(\mathrm{pH}<4)$ egyik fémion jelenlétében sem tapasztaltunk jelentős különbséget a szabad ligandum spektrumaihoz képest (5.1.3.4. ábra). A pH növelésével legszembetűnőbb a jelek jelentős mértékű kiszélesedése (5.2.2.1.3. ábra). Ezt egyebek mellett okozhatja pl. az egyes kötőhelyek közötti közepesen gyors/lassú fémion-csere az NMR időskálájához viszonyítva, vagy a ligandum konformációváltozásának lassulása. Összhangban az UV-titrálások eredményével, a ciszteinek $\mathrm{C}_{\beta} \mathrm{H}_{2}$ jelein tapasztalható változás (kiszélesedés és eltolódás) alapján, $\mathrm{pH}=5$ felett már mindkét fémion esetén egyértelműen számolhatunk tiolát-koordinációval.
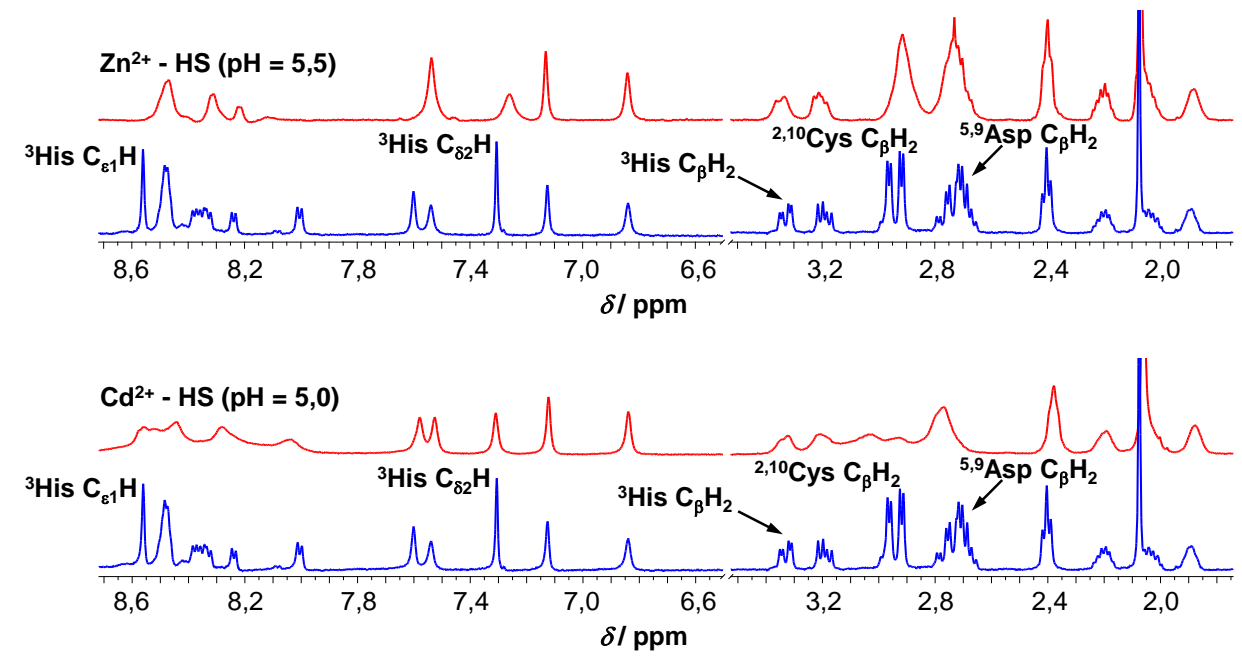

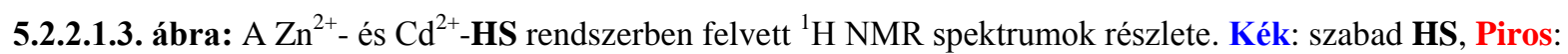
$\mathrm{Zn}^{2+}$ - és $\mathrm{Cd}^{2+}$-HS 1:1 ( $\left.c_{\mathrm{HS}}=1,3 \times 10^{-3} \mathrm{M}, \mathrm{H}_{2} \mathrm{O} / \mathrm{D}_{2} \mathrm{O}=90 / 10 \% \mathrm{v} / \mathrm{v}, I=0,1 \mathrm{M} \mathrm{NaClO}_{4}, T=298 \mathrm{~K}\right)$

A His $\mathrm{C}_{\beta} \mathrm{H}_{2}$, valamint $\mathrm{C}_{\varepsilon 1} \mathrm{H}$ és $\mathrm{C}_{\delta 2} \mathrm{H}$ jelek $\mathrm{Cd}^{2+}$-ionok jelenlétében a kiszélesedés ellenére is hasonlóak a szabad ligandum megfelelő jeleivel. Ezek alapján a His imidazolcsoportja, az eddigi vizsgálatok eredményeivel összhangban, a CdHL képződésének tartományában még nem kötődik a fémionhoz. Ugyanakkor $\mathrm{Zn}^{2+}$-ionok esetén a His $\mathrm{C}_{\beta} \mathrm{H}_{2}$, valamint $\mathrm{C}_{\varepsilon 1} \mathrm{H}$ és $\mathrm{C}_{\delta 2} \mathrm{H}$ rezonanciák is kismértékben eltolódtak a szabad ligandum His jeleihez képest. Azonban a pH növelésével a His imidazolcsoport jelei a szabad ligandum 
jeleivel (5.1.3.3/5.1.3.4. ábra) nagyon hasonlóan, a magasabb terek irányába tolódnak, ami azt mutatja, hogy ezen a pH-n a His koordináció még nem teljes. Valószínüleg a ZnHL részecskéből többféle izomer lehet jelen, melyekben vagy a két Cys tiolátcsoportja, vagy egy Cys tiolát-, és egy His imidazolcsoport kötődik a fémionhoz.

Semleges pH-tartományban ( $\mathrm{pH} \sim 7,5)$ a $\mathrm{ZnL}$ és CdL törzskomplexek spektrumain a jelek szélesedése továbbra is a komplexek különböző konformációi között közepes cseresebességre utal. Itt azonban már mindkét fémion esetén szignifikáns eltérés figyelhető a szabad ligandumhoz képest az Asp és Cys jelek mellett a His jeleken is (5.2.2.1.4. ábra). Ez alapján feltételezhető, hogy a peptid His imidazolcsoportja a $\mathrm{ZnL}$ és CdL törzskomplexekben is kötődik a fémionhoz $\left\{2 \times \mathrm{S}^{-}, \mathrm{N}_{\mathrm{im}}, \mathrm{X}\right\}$ koordinációs környezet alakítva ki, ahol az X Asp karboxilcsoportot és/vagy koordinált vízmolekulát jelenthet.
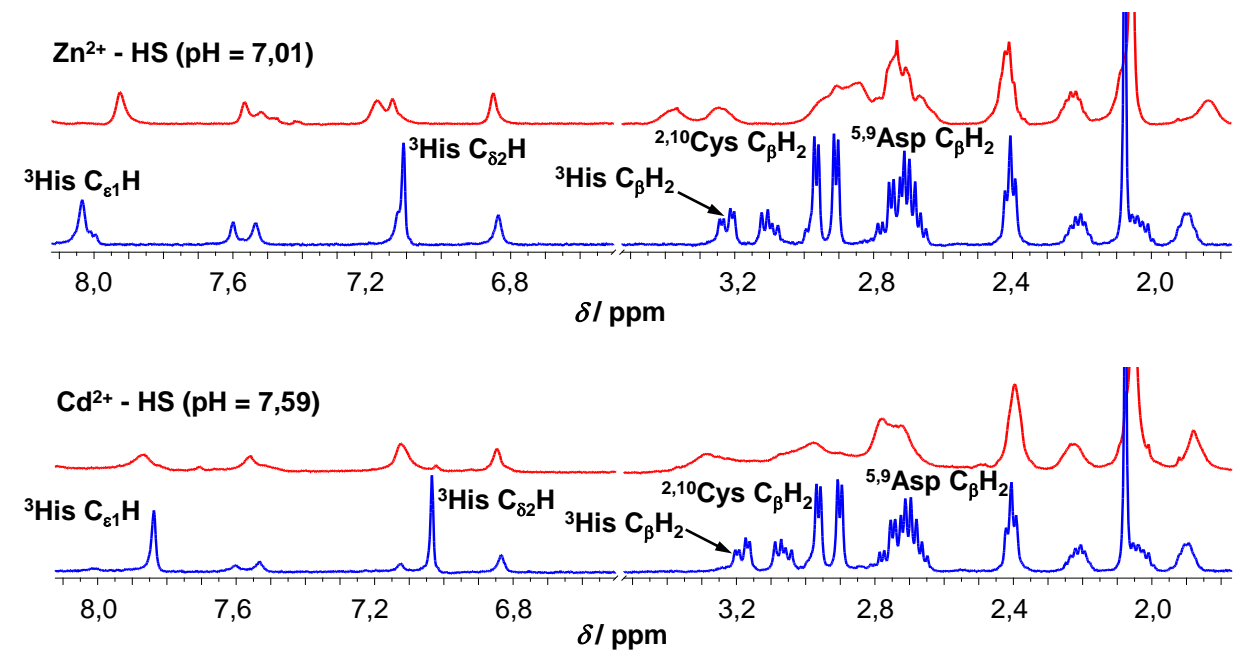

5.2.2.1.4. ábra: $\mathrm{A} \mathrm{Zn}^{2+}$ - és $\mathrm{Cd}^{2+}-\mathrm{HS}$ rendszerben felvett ${ }^{1} \mathrm{H}$ NMR spektrumok részlete. Kék: szabad HS, Piros: $\mathrm{Zn}^{2+}$ - és $\mathrm{Cd}^{2+}-\mathrm{HS} 1: 1\left(c_{\mathrm{HS}}=1,3 \times 10^{-3} \mathrm{M}, \mathrm{D}_{2} \mathrm{O} / \mathrm{H}_{2} \mathrm{O}=10: 90 \% \mathrm{v} / \mathrm{v}, I=0,1 \mathrm{M} \mathrm{NaClO}_{4}, T=298 \mathrm{~K}\right)$

Egy dán kutatóval (Niels Johann Christensen) történő együttmüködés keretében geometriai optimalizálással meggyőződtünk arról, hogy ezek a szerkezetek valóban kialakulhatnak (5.2.2.1.5. ábra).
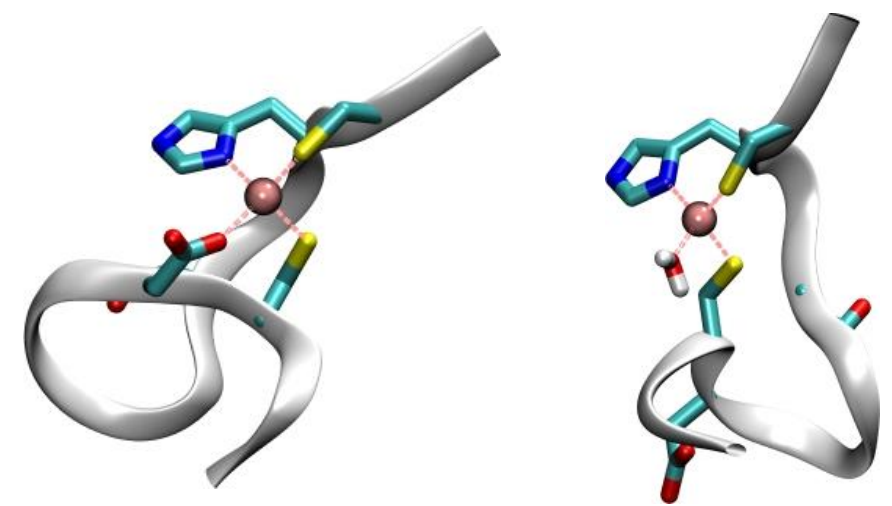

5.2.2.1.5. ábra $A\left\{2 \times S^{-}, N_{i m}, X\right\}$ koordinációs környezetü CdL komplex geometriai optimalizálással kapott lehetséges szerkezetei $\left(T=298 \mathrm{~K}, \mathrm{pH}=7,5, \mathrm{X}=\mathrm{COO}^{-} / \mathrm{H}_{2} \mathrm{O}\right)$ 


\subsubsection{A ligandumfelesleget tartalmazó rendszerek vizsgálata}

Biszkomplexek képződésének lehetőségét az 5.2.1.2. fejezethez hasonlóan a Histartalmú HS ligandummal is vizsgáltuk, mivel itt további potenciális donorcsoport áll rendelkezésünkre. $\mathrm{Zn}^{2+}$-ionok jelenlétében savas/semleges $\mathrm{pH}$-tartományban ligandumfelesleg mellett is a $\mathrm{ZnHL}$ és $\mathrm{ZnL}$ monokomplexek dominálnak. Ezzel ellentétben $\mathrm{Cd}^{2+}$-ionok esetén $\mathrm{pH}=7$ környékén a képződő biszkomplexek mennyisére már meghaladja a monokomplexekét (5.2.2.2.1. ábra).
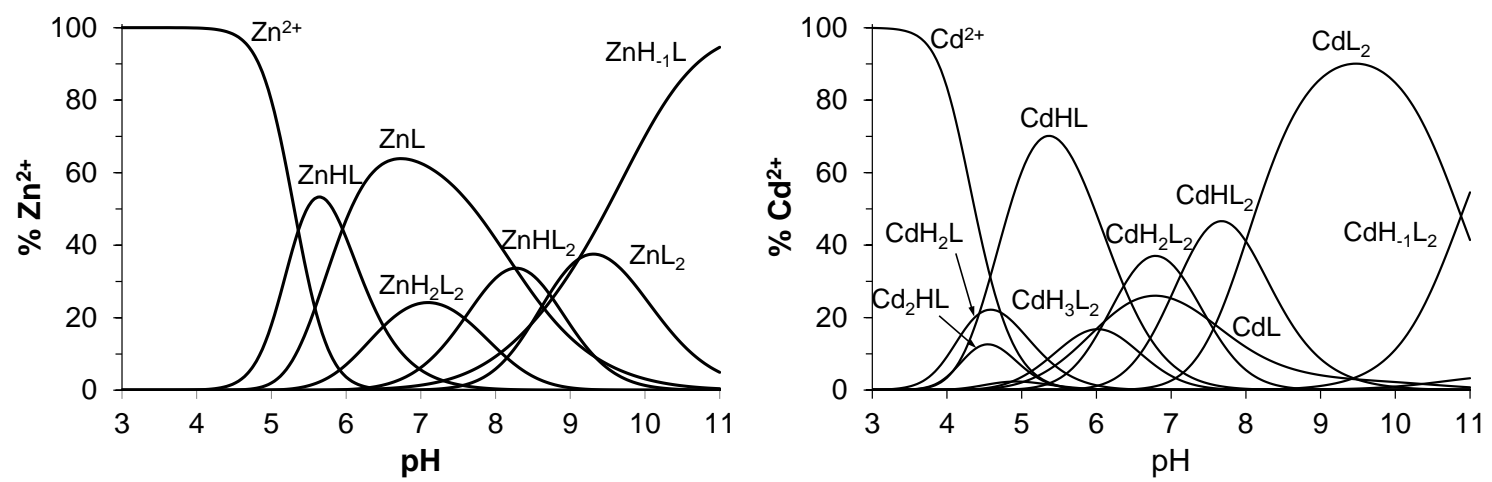

5.2.2.2.1. ábra: $\mathrm{A} \mathrm{Zn}^{2+}$ - és $\mathrm{Cd}^{2+}$-HS $0,5: 1$ fémion:ligandum arányú rendszerek eloszlási diagramjai

$$
\left(c_{\text {HS }}=1,0 \times 10^{-3} \mathrm{M}, I=0,1 \mathrm{M} \mathrm{NaClO}_{4}, T=298 \mathrm{~K}\right)
$$

$\mathrm{A} \mathrm{Zn}^{2+}$-, és $\mathrm{Cd}^{2+}$-HS komplexben a ligandum $\rightarrow$ fémion elektronátmenetet jellemző töltésátviteli sávot vizsgálva $\mathrm{pH} \sim 5$-5,5-től az abszorbancia emelkedés a tiolátcsoportok kötődését mutatja (F22., F25. ábrák). Azonban ez mindkét esetben kisebb, mint az 1:1 összetételü rendszerben (5.2.2.2.2. ábra), amely a fémionok eltérő koordinációs környezetére utal.
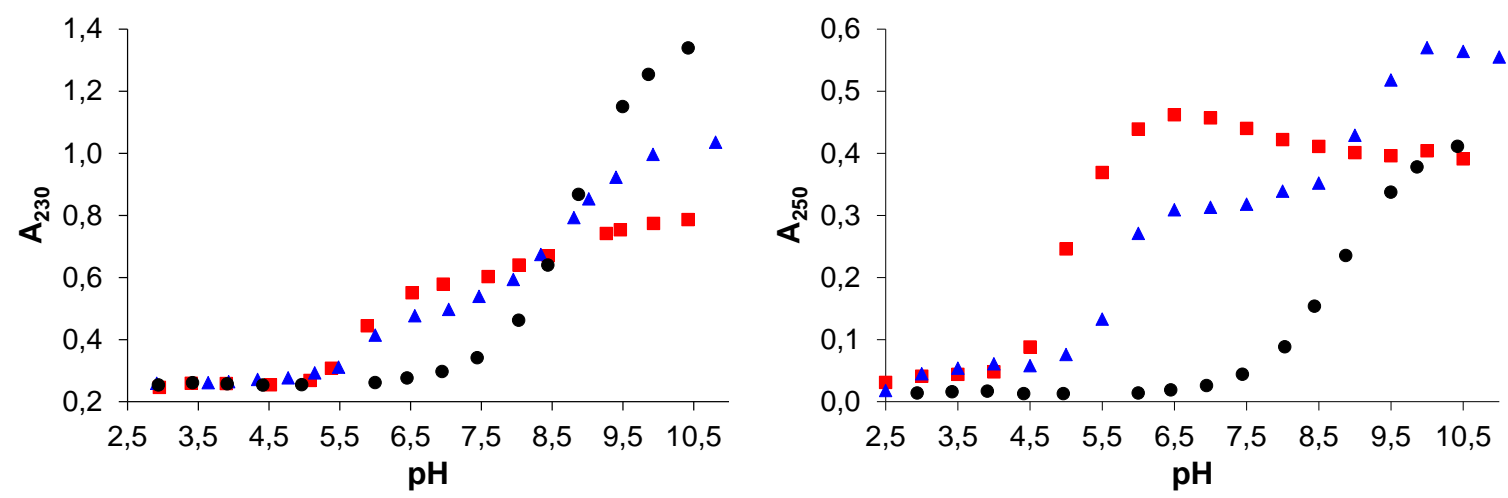

5.2.2.2.2. ábra: $\mathrm{Zn}^{2+}-\mathrm{HS}$ (bal) és a $\mathrm{Cd}^{2+}-\mathrm{HS}$ (jobb) különböző fémion:ligandum arányú rendszerek $\mathrm{A}$ vs. $\mathrm{pH}$

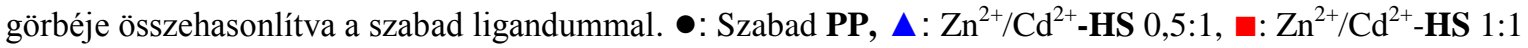
$\left(c_{\mathrm{HS}}=1,0 \times 10^{-4} \mathrm{M}, I=0,1 \mathrm{M} \mathrm{NaClO}_{4}, l=10 \mathrm{~mm}, T=298 \mathrm{~K}\right)$

A $\mathrm{ZnH}_{2} \mathrm{~L}_{2}$ és $\mathrm{CdH}_{2} \mathrm{~L}_{2}$ komplexek deprotonálódása révén jutunk el a $\mathrm{ZnL}_{2}$ és $\mathrm{CdL}_{2}$ részecskékhez. $\mathrm{Az} \mathrm{MHL}_{2} \rightarrow \mathrm{ML}_{2}$ folyamathoz rendelhető egyensúlyi állandó $\left(\mathrm{p} K_{\mathrm{ZnHL}_{2}}=\right.$ 8,$\left.72 ; \mathrm{p} K_{\mathrm{CdHL}_{2}}=8,00\right)$ viszonylag magas, mely alapján feltételezhetö, hogy a $\mathrm{MH}_{2} \mathrm{~L}_{2}$ és 
$\mathrm{MHL}_{2}$ részecskékben protonált tiolcsoportok vannak. A második ligandum kötődését jellemző $\lg K_{2}=4,37\left(\lg K_{2}=\lg \beta_{\mathrm{ZnL}_{2}}-\lg \beta_{\mathrm{ZnL}}\right)$ két nagyságrenddel elmarad a $\mathrm{Cd}^{2+}$-ionok jelenlétében számolt $\lg K_{2}=6,45$-től, amely mutatja a $\mathrm{CdL}_{2}$ komplex nagyobb stabilitását, azonban ezek az értékek mindkét esetben elmaradnak a rövidebb tagszámú peptideknél tapasztaltaktól (5.2.1.1.2. táblázat), melynek oka az 5.2.1.2. fejezetben tárgyaltakhoz hasonlóan sztérikus okokban és a peptidek elektrosztatikus taszításában keresendő.

Lúgos körülmények között az UV görbéken újabb abszorbancia-növekedést látunk. A $\mathrm{Zn}^{2+}$-iont tartalmazó rendszerben mérhető abszorbancia az 1:1 fémion: ligandum arányú rendszer és a szabad ligandum átlagához közel helyezkedik el. Ez jó egyezést mutat a pHpotenciometriás eredményekkel, miszerint a $\mathrm{ZnL}_{2}$ komplex disszociál $\mathrm{ZnH}_{-1} \mathrm{~L}$ részecskévé és szabad ligandummá. $\mathrm{Zn}^{2+}$-ionokat tartalmazó rendszerben az UV-spektroszkópiai mérések során alkalmazott $1,0 \times 10^{-4}$ M-os ligandum koncentráció mellett kis mennyiségü biszkomplex képződött (F22. ábra), melynek létezését az átfedő folyamatok és a törzskomplex korai hidrolízise miatt nehéz fotometriás módszerrel bizonyítani.

Azonban $\mathrm{CdL}_{2}$ képződését kísérő abszorbancia-változás mértéke hasonló a semleges pH-n tapasztalttal, továbbá a szabad ligandum abszorbanciájánál is magasabb, ami alapján nagy valószínüséggel lúgos körülmények között mind a négy tiolátcsoport koordinál a fémionhoz. Fontos megemlítenünk, hogy a HS két aszparaginsavat is tartalmaz, amelyek komplexképződésben való részvételének megállapításához az UV-mérések nem elegendőek. Továbbá a HS ligandummal képződő biszkomplexekben a monokomplexekhez hasonlóan fontos szerepe lehet a His imidazolcsoportjának is. Ennek alaposabb megismerése érdekében kétszeres ligandumfelesleg mellett is végeztünk ${ }^{1} \mathrm{H}$ NMR méréseket.

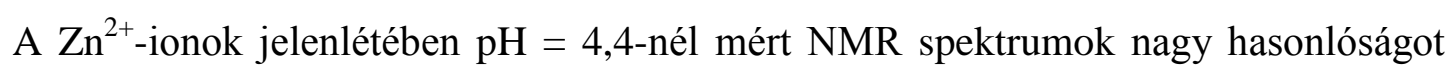
mutatnak az 1:1 fémion:ligandum arányú rendszer és a szabad ligandum spektrumával is. Ezek alapján ligandumfelesleg mellett sem kötődnek a $\mathrm{Zn}^{2+}$-ionok a HS ligandumhoz. A pHt növelve azonban fémion jelenlétében a jelek kiszélesedését tapasztaltuk, ami összhangban a $\mathrm{pH}$ potenciometriás és UV spektroszkópiai eredményekkel a $\mathrm{Zn}^{2+}$-HS komplexek képződését jelzi (F34. ábra).

pH = 7,0-nál különbség figyelhető meg a ligandumfelesleghez tartozó és az 1:1 fémion:ligandum arányú rendszer spektruma között (5.2.2.2.3. ábra). A jelek 0,5:1 arány mellett jelentősebben kiszélesedtek, melyet az ezen a pH-n jelenlévő eltérő összetételü komplexek (5.2.2.2.1. ábra, $\mathrm{ZnL}, \mathrm{ZnH}_{2} \mathrm{~L}_{2}$ ) és a szabad ligandum közötti a ligandumcsere sebességének csökkenése okozhat. A szabad ligandum jelenlétét bizonyítja a $\delta \sim 2,90$ ppm kémiai eltolódásnál látható, szabad $\mathrm{Cys}_{\beta} \mathrm{H}_{2}$ jelére nagyon hasonló rezonancia is. 


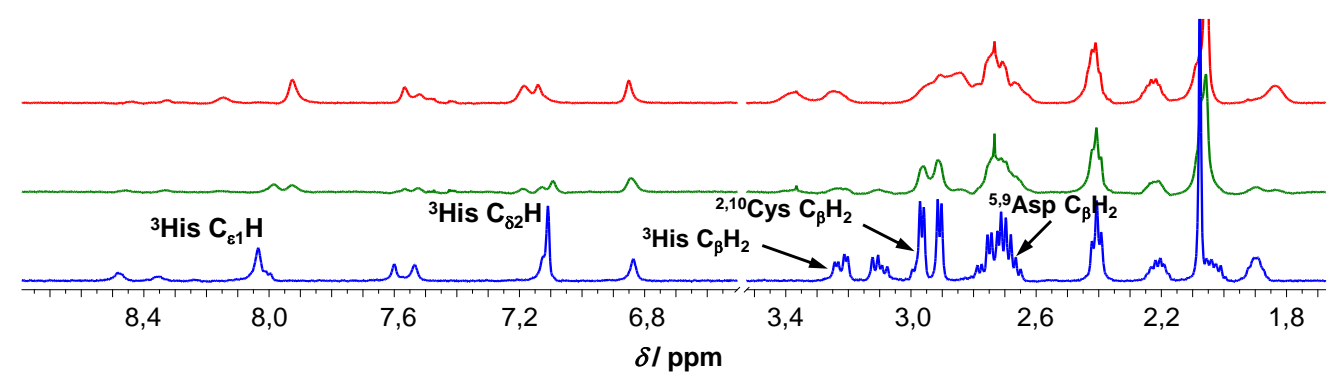

5.2.2.2.3. ábra: $\mathrm{A} \mathrm{Zn}^{2+}-\mathbf{H S}$ rendszerben felvett ${ }^{1} \mathrm{H}$ NMR spektrumok részlete. Kék: szabad $\mathbf{H S}$, Zöld: $\mathrm{Zn}^{2+}-\mathbf{H S}$ 0,5:1, Piros: $\mathrm{Zn}^{2+}-\mathrm{HS} 1: 1\left(c_{\mathrm{HS}}=1,3 \times 10^{-3} \mathrm{M}, \mathrm{H}_{2} \mathrm{O} / \mathrm{D}_{2} \mathrm{O}=90 / 10 \% \mathrm{v} / \mathrm{v}, I=0,1 \mathrm{M} \mathrm{NaClO}_{4}, \mathrm{pH}=7,0, T=298 \mathrm{~K}\right)$

Míg az 1:1 fémion:ligandum arányú rendszernél semleges $\mathrm{pH}-n$ egyértelmü a tiolátcsoportok és az imidazolcsoportok részvétele a fémion kötésben, addig ligandumfelesleg mellett a jelek kiszélesedése és a rendszer összetettsége miatt nehéz azonosítani a $\mathrm{ZnH}_{2} \mathrm{~L}_{2}$ részecskében koordinálódó donorcsoportokat.

A pH növelésével $(\mathrm{pH}=9,4)$ a jelek továbbra is szélesek (5.2.2.2.4. ábra), azonban $\mathrm{pH}=7,0$-hoz képest a $\mathrm{Cys} \mathrm{C}_{\beta} \mathrm{H}_{2}$ protonjaihoz rendelhető jelek szignifikánsan megváltoztak. azonban a pH-potenciometriás és UV spektroszkópiai vizsgálatok eredményei alapján a szabad HS Cys tiolcsoportjainak protonvesztése is $\mathrm{pH}=7,5-9,5$ tartományban következik be (5.1.2.1. táblázat).

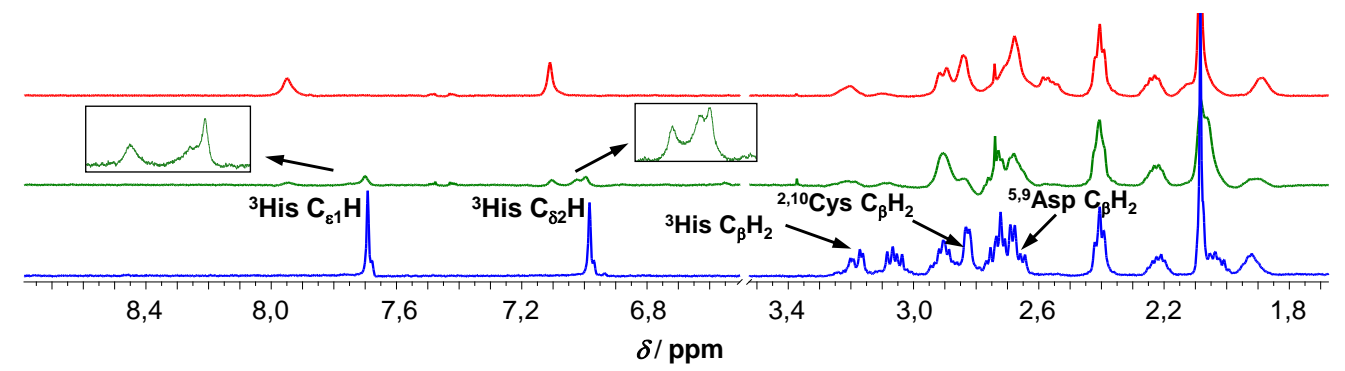

5.2.2.2.4. ábra: $\mathrm{A} \mathrm{Zn}^{2+}-\mathbf{H S}$ rendszerben felvett ${ }^{1} \mathrm{H}$ NMR spektrumok részlete. Kék: szabad $\mathbf{H S}, \mathrm{Zöld}: \mathrm{Zn}^{2+}-\mathbf{H S}$ 0,5:1; Piros: $\mathrm{Zn}^{2+}-\mathrm{HS} 1: 1\left(c_{\mathrm{HS}}=1,3 \times 10^{-3} \mathrm{M}_{1} \mathrm{H}_{2} \mathrm{O} / \mathrm{D}_{2} \mathrm{O}=90 / 10 \% \mathrm{v} / \mathrm{v}, I=0,1 \mathrm{M} \mathrm{NaClO}_{4}, \mathrm{pH}=9,4, T=298 \mathrm{~K}\right)$

Továbbá pH = 9,4-nél a monokomplex és az esetleges biszkomplexek hidrolízise $\left(\mathrm{ZnH}_{-1} \mathrm{~L}\right.$ részecske és szabad $\mathbf{H S}$ képződése) is megkezdődött. Ezért pusztán a $\mathrm{Cys}_{\beta} \mathrm{C}_{\beta} \mathrm{H}_{2}$ jeleinek változásából biszkomplexek jelenlétét bizonyítani nagyon nehéz.

A His imidazolcsoportjához rendelhető $\mathrm{C}_{\varepsilon 1} \mathrm{H}$ és $\mathrm{C}_{\delta 2} \mathrm{H}$ jelek szélesek, azonban a azokat jobban szemügyre véve három, egymástól különböző jelet látunk. $\mathrm{A}_{\varepsilon 1} \mathrm{H}$ és $\mathrm{C}_{\delta 2} \mathrm{H}$ jelek közül az egyik nagyon hasonló a szabad ligandumnál tapasztalt rezonanciákhoz, a másik pedig az 1:1 fémion ligandum arányú rendszerben mértekhez, a kötött His-re jellemző jel. Azonban egy harmadik jelet is láthatunk a szabad és kötött imidazolcsoporthoz tartozó jelek között, ami egy új kémiai környezetben lévő hisztidinhez tartozó csúcs lehet. 
Ennek bizonyítására $\mathrm{pH} \sim$ 8,0-nál végeztünk olyan méréseket, ahol állandó ligandumkoncentráció mellett változtattuk a fémion-koncentrációt 0:1-1:1 fémion:ligandum arány között (5.2.2.2.5. ábra). A szabad ligandumhoz rendelhető jelek intenzitása a fémion koncentrációjának növelésével csökken. Ezzel párhuzamosan 0,5:1 arány eléréséig fokozatosan fejlődik ki egy újabb jel $\delta=7,03$ és 7,80 ppm-nél, mely egyértelmüen eltért a szabad ligandumban tapasztaltaktól.

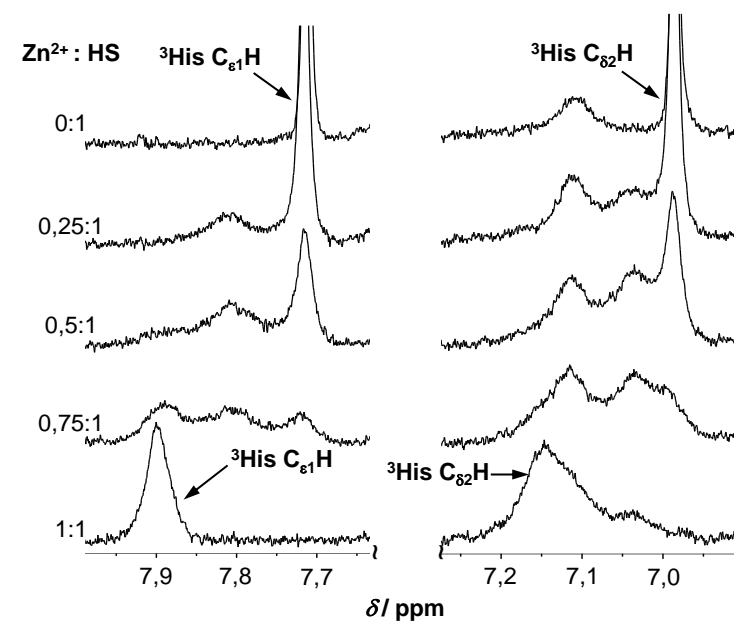

5.2.2.2.5. ábra: $\mathrm{A} \mathrm{Zn}^{2+}-\mathrm{HS}$ rendszerben felvett ${ }^{1} \mathrm{H} N M R$ spektrumok részlete, a $\mathrm{Zn}^{2+}-\mathrm{HS}$ arány függvényében $\left(c_{\mathrm{HS}}=1,3 \times 10^{-3} \mathrm{M}, \mathrm{H}_{2} \mathrm{O} / \mathrm{D}_{2} \mathrm{O}=90 / 10 \% \mathrm{v} / \mathrm{v}, I=0,1 \mathrm{M} \mathrm{NaClO}_{4}, \mathrm{pH}=8,0, T=298 \mathrm{~K}\right)$

A fémion koncentrációjának növelésével megjelenő széles, de egymástól elkülönülő jelek három egymással lassú cserében lévő részecskére utalnak (ez a $\mathrm{C}_{\varepsilon 1} \mathrm{H}$ jeleknél 0,75:1, míg a $\mathrm{C}_{\delta 2} \mathrm{H}$ rezonanciánál 0,5:1 fémion ligandum aránynál látható a legjobban). Ezek a szabad ligandum, a ZnL részecske és egy biszkomplex lehet. A közepesen lassú cserében lévő részecskékben a két ligandum közül legalább az egyik His imidazolcsoportja koordinálhat a fémionhoz.

A pH növelésével a His imidazolcsoport gyürüprotonjaihoz már csak két jel rendelhető (5.2.2.2.6. ábra).

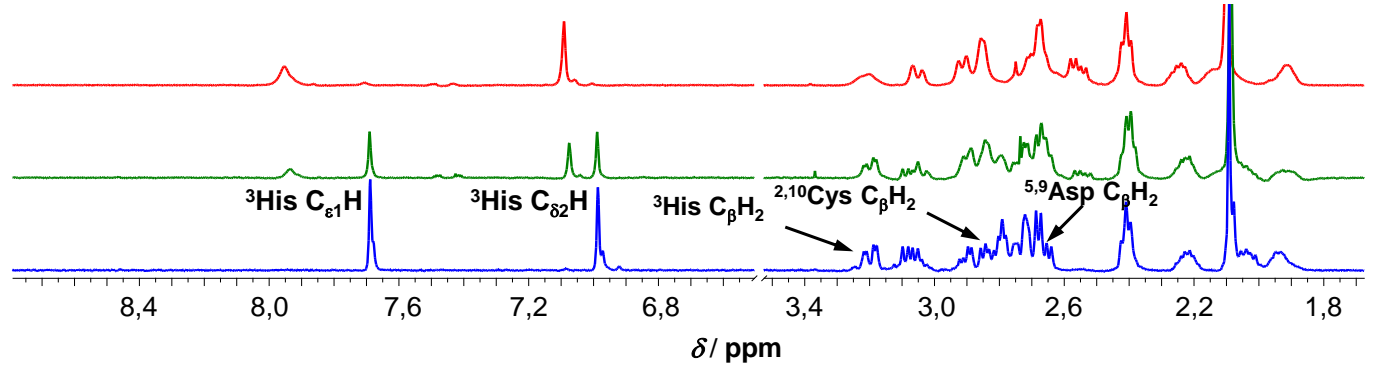

5.2.2.2.6. ábra: $A \mathrm{Zn}^{2+}-\mathbf{H S}$ rendszerben felvett ${ }^{1} \mathrm{H}$ NMR spektrumok részlete Kék: szabad $\mathbf{H S}, \mathbf{Z o ̈ l d}: \mathrm{Zn}^{2+}-\mathbf{H S}$ 0,5:1, Piros: $\mathrm{Zn}^{2+}{ }_{-} \mathrm{HS} 1: 1\left(c_{\mathrm{HS}}=1,3 \times 10^{-3} \mathrm{M}, \mathrm{H}_{2} \mathrm{O} / \mathrm{D}_{2} \mathrm{O}=90 / 10 \% \mathrm{v} / \mathrm{v}, I=0,1 \mathrm{M} \mathrm{NaClO}_{4}, \mathrm{pH}=11, T=298 \mathrm{~K}\right)$

Az egyik jó egyezésben a szabad ligandum azonos jeleivel, a másik azonos kémiai eltolódású az ekvimoláris $\mathrm{Zn}^{2+}$-ionokat tartalmazó rendszerben mérttel. 
Az eloszlási diagramokkal és UV mérésekkel jó egyezésben magas $\mathrm{pH}-\mathrm{n}$ kizárólag $\mathrm{ZnH}_{-1} \mathrm{~L}$ komplex és szabad ligandum van jelen a rendszerben, amelyek között a ligandumcsere sebessége lassú.

A $\mathrm{Cd}^{2+}$-ionokat tartalmazó rendszerben semleges $\mathrm{pH}$ tartományban szintén a jelek kiszélesedését tapasztaltuk (5.2.2.2.7. ábra). A 0,5:1 (fémion:ligandum) arány mellett mért spektrumokon szembetünő, hogy a $\mathrm{Cys} \mathrm{C}_{\beta} \mathrm{H}_{2}$ rezonanciák egy része a magasabb terek (alacsonyabb ppm értékek) irányába tolódott, valamint a His $\mathrm{C}_{\beta} \mathrm{H}_{2}$ rezonanciái mellett az imidazolcsoport $\mathrm{C}_{\varepsilon 1} \mathrm{H}$, és $\mathrm{C}_{\delta 2} \mathrm{H}$ jelek kémiai eltolódása is eltér a szabad ligandumra jellemző értékektől. Ugyanakkor nagyon hasonló az ekvimoláris $\mathrm{Cd}^{2+}$-iont tartalmazó minta spektrumához.

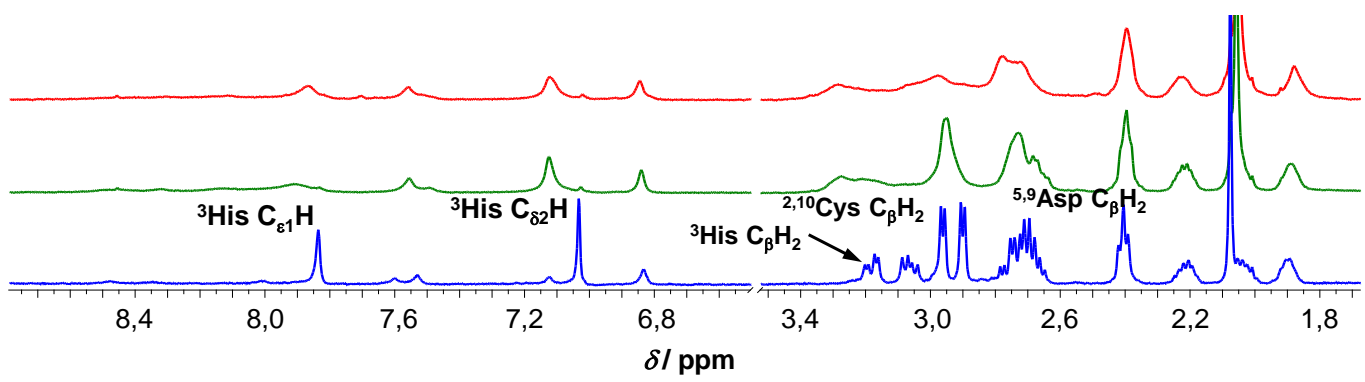

5.2.2.2.7. ábra: $\mathrm{A} \mathrm{Cd}{ }^{2+}-\mathbf{H S}$ rendszerben felvett ${ }^{1} \mathrm{H}$ NMR spektrumok részlete. Kék: szabad $\mathbf{H S}$, Zöld: $\mathrm{Cd}^{2+}{ }_{-} \mathbf{H S}$ 0,5:1, Piros: $\mathrm{Cd}^{2+}-\mathrm{HS} 1: 1\left(c_{\mathrm{HS}}=1,3 \times 10^{-3} \mathrm{M}, \mathrm{H}_{2} \mathrm{O} / \mathrm{D}_{2} \mathrm{O}=90 / 10 \% \mathrm{v} / \mathrm{v}, I=0,1 \mathrm{M} \mathrm{NaClO}_{4}, \mathrm{pH}=7,5, T=298 \mathrm{~K}\right)$

Ennek magyarázata az lehet, hogy $\mathrm{pH}=7,50$-nél a már képződő biszkomplexben a két ligandum koordinációs módja megegyezik a monokomplexre jellemző $\left(2 \times \mathrm{S}^{-}, \mathrm{N}_{\mathrm{im}}, \mathrm{X}\right)$ kötésmóddal. Ennek megfelelően a semleges pH környékén képződő $\mathrm{CdH}_{2} \mathrm{~L}_{2}$ biszkomplexben a két ligandum egy-egy Cys tiolátcsoportjának és His imidazolcsoportjának kötődésén keresztül alakítja ki $\left\{2 \times \mathrm{S}^{-}, 2 \times \mathrm{N}_{\mathrm{im}}\right\}$ típusú koordinációs szféra valószínüsíthető (5.2.2.2.8. ábra).

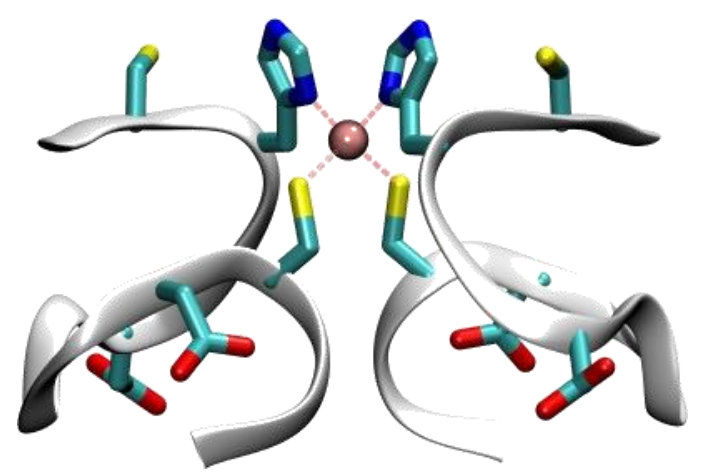

5.2.2.2.8. ábra: $A\left\{2 \times \mathrm{S}^{-}, 2 \times \mathrm{N}_{\mathrm{im}}\right\}$ koordinációs környezetü $\mathrm{CdH}_{2} \mathrm{~L}_{2}$ komplex geometriai optimalizálással kapott szerkezete $(T=298 \mathrm{~K}, \mathrm{pH}=7,5)$

Ezt alátámasztja az UV mérések eredménye is (5.2.2.2.2. ábra), miszerint a $\mathrm{CdH}_{2} \mathrm{~L}_{2}$ részecskében a tiolcsoportoknak csak egy része kötődik a fémionhoz. 
A pH-t növelve szembetünő változások tapasztalhatók (5.2.2.2.10. ábra). A His $\mathrm{C}_{\varepsilon 1} \mathrm{H}$ és $\mathrm{C}_{\delta 2} \mathrm{H}$ jelei a $\mathrm{pH}=7,5$-nél mért spektrumhoz képest fokozatosan eltolódnak a kisebb ppm értékekkel jellemezhető, a szabad ligandumban mért rezonanciák felé.

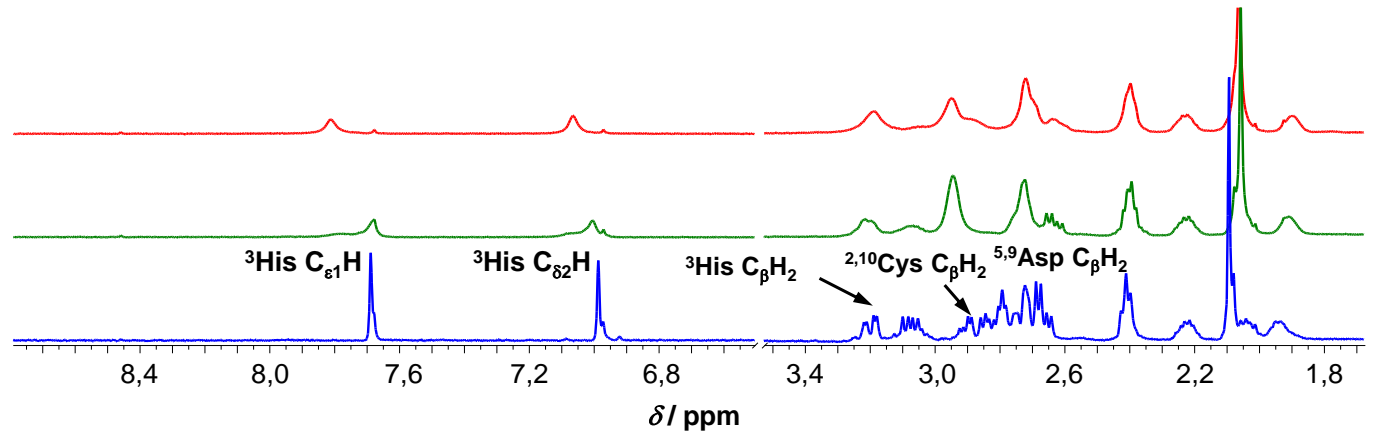

5.2.2.2.10. ábra: $\mathrm{A} \mathrm{Cd}^{2+}-\mathbf{H S}$ rendszerben felvett ${ }^{1} \mathrm{H}$ NMR spektrumok részlete. Kék: szabad HS, Zöld: $\mathrm{Cd}^{2+}$ HS 0,5:1, Piros: $\mathrm{Cd}^{2+}-\mathrm{HS} 1: 1\left(c_{\mathrm{HS}}=1,3 \times 10^{-3} \mathrm{M}, \mathrm{H}_{2} \mathrm{O} / \mathrm{D}_{2} \mathrm{O}=90 / 10 \% \mathrm{v} / \mathrm{v}, I=0,1 \mathrm{M} \mathrm{NaClO}_{4}, \mathrm{pH}=10,5, T=298 \mathrm{~K}\right)$

Az NMR, az elektrongerjesztési spektrumok és az eloszlási diagramok alapján a 7,59,5 pH-tartományban lejátszódó folyamat a következő lehet: a semleges pH tartományban domináns $\mathrm{CdH}_{2} \mathrm{~L}_{2}$ komplexben a $\left\{2 \times \mathrm{S}^{-}, 2 \times \mathrm{N}_{\mathrm{im}}\right\}$ koordinációs környezet a ligandum két újabb Cys oldallánci tiolátcsoportjának koordinálódásával fokozatosan alakul át a $\mathrm{CdL}_{2}$-ben tapasztalt $\left\{4 \times \mathrm{S}^{-}\right\}$koordinációs környezetü komplexszé. Ezzel párhuzamosan a His imidazolcsoportok kiszorulnak a $\mathrm{Cd}^{2+}$-ionok koordinációs szférájából (5.2.2.2.11. ábra). Ezért jelennek meg pH = 8,40-nél a kötött és szabad hisztidinre jellemző kémiai eltolódás értékek között, majd $\mathrm{pH}=10,0$ felett a szabad ligandumban tapasztalt $\mathrm{C}_{\varepsilon 1} \mathrm{H}$ és $\mathrm{C}_{\delta 2} \mathrm{H}$ rezonanciákkal teljesen egyező csúcsok.

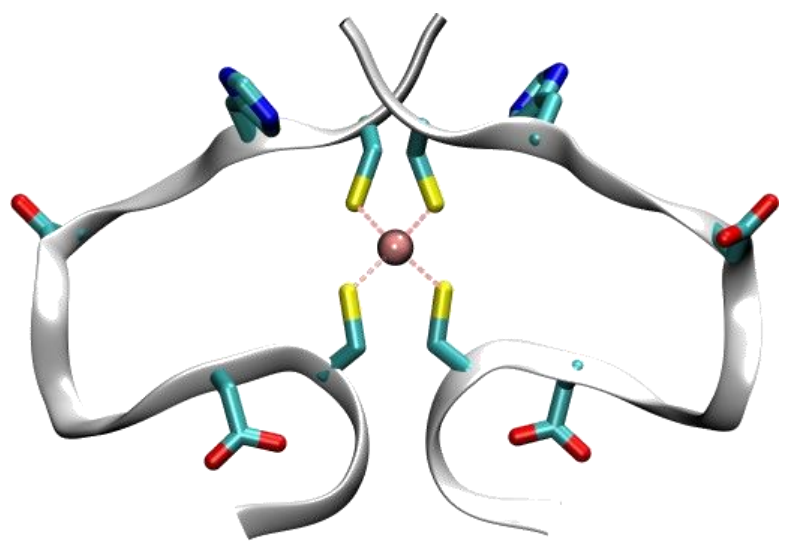

5.2.2.2.11. ábra: $A\left\{4 \times S^{-}\right\}$koordinációs környezetü $\mathrm{CdL}_{2}$ részecske geometriai optimalizálással kapott szerkezete $(T=298 \mathrm{~K}, \mathrm{pH}=10,0)$ 


\subsubsection{A $\mathrm{Zn}^{2+}$-, és $\mathrm{Cd}^{2+}$-komplexek stabilitásainak összehasonlítása}

A négy ligandum szekvenciájának különbözősége ellenére a pH-potenciometriás vizsgálatokkal meghatározott stabilitási állandók alapján a peptidek rendkívül hasonló affinitását mutatják a $\mathrm{Zn}^{2+}$-, és $\mathrm{Cd}^{2+}$-ionokhoz (5.2.3.1. táblázat).

\begin{tabular}{c|cc|cc|c|} 
Peptid & \multicolumn{2}{|c|}{$\mathbf{C d}^{2+}, \mathbf{l g} K_{\text {app }}$} & \multicolumn{2}{|c|}{$\mathbf{Z n}^{2+}, \mathbf{l g} K_{\text {app }}$} & Javasolt koordinációs \\
& $\mathrm{pH}=7,00$ & $\mathrm{pH}=8,00$ & $\mathrm{pH}=7,00$ & $\mathrm{pH}=8,00$ & \multicolumn{1}{c|}{ mód } \\
\hline PP & 8,27 & 10,09 & 6,48 & 8,29 & $2 \times \mathrm{S}^{-}, \mathrm{COO}^{-},\left(\mathrm{H}_{2} \mathrm{O} / \mathrm{COO}^{-}\right)$ \\
PS & 8,20 & 10,03 & 6,53 & 8,39 & $2 \times \mathrm{S}^{-}, \mathrm{COO}^{-},\left(\mathrm{H}_{2} \mathrm{O} / \mathrm{COO}^{-}\right)$ \\
HS & 8,26 & 10,11 & 7,02 & 9,06 & $2 \times \mathrm{S}^{-}, \mathrm{N}_{\mathrm{im}},\left(\mathrm{COO}^{-} / \mathrm{H}_{2} \mathrm{O}\right)$ \\
EC & 8,57 & 10,52 & 6,90 & 8,87 & $2 \times \mathrm{S}^{-}, \mathrm{COO}^{-},\left(\mathrm{COO}^{-} / \mathrm{H}_{2} \mathrm{O}\right)$ \\
\hline
\end{tabular}

5.2.3.1. táblázat: $\mathrm{A} \mathrm{Zn}^{2+}$ - és $\mathrm{Cd}^{2+}$-ionok affinitása az általunk vizsgált Cys tartalmú peptidekhez

$$
K_{\text {app }}=\frac{\sum\left[\mathrm{M}^{2+}\right]_{\text {kötött }}}{\left[\mathbf{M}^{2+}\right]_{\text {szabad }} \times \sum[L]_{\text {szabad }}}
$$

Ez arra utal, hogy a fémionok koordinációjában meghatározó szerepe van a Cys egységeknek, amelyhez képest a többi potenciális donorcsoport hatása vagy nem túl jelentős, vagy mind a négy ligandum esetében hasonló mértékben járulnak hozzá a komplexek stabilitásához. A fémionok koordinációs környezetét az Asp karboxilátcsoportok illetve vízmolekula egészítheti ki, így a fémionok körül tetraéderes/torzult tetraéderes geometria alakul ki.

Kismértékü stabilitás-növekedést az EC-peptid komplexeiben a harmadik Asp karboxilcsoportjának koordinációban való részvétele okozhatja. Érdekes módon hisztidin jelenléte a $\mathrm{Cd}^{2+}$-affinitásában nem okoz különbséget. Azonban a $\mathrm{Zn}^{2+}$-ionok mellett a His imidazolcsoportnak jelentősebb szerepe van a komplexek kialakításában.

$\mathrm{Az}$ azonos ligandumok $\mathrm{Zn}^{2+}$ - és $\mathrm{Cd}^{2+}$-komplexeinek stabilitása közötti különbség a $\mathrm{Cd}^{2+}$-ionok szoftabb karakterével és a tiolátcsoporthoz való nagyobb affinitásával magyarázható.

A rövidebb peptidek (mint például a 3.4 .3 fejezetben tárgyalt $\mathrm{PC} 2$ molekulák) $\mathrm{Cd}^{2+}$ komplexeiben megfigyelt karboniloxigén koordinációt az általunk vizsgált komplexekben nem tapasztaltuk, továbbá mivel peptidjeink $\mathrm{N}$-, és C-terminálisan is védettek, nem lehetséges az N-terminális aminocsoport kötődése a fémionokhoz. 


\subsection{A ligandumok $\mathrm{Hg}^{2+}$-ionokkal alkotott komplexeinek vizsgálata}

\subsubsection{A hisztidint nem tartalmazó ligandumok $\mathrm{Hg}^{2+}$-komplexei}

A $\mathrm{Hg}^{2+}$-ionok jelenlétében képződő komplexek kiemelkedő stabilitása miatt pHpotenciometriás mérések kivitelezése bonyolult lett volna. A komplexek stabilitásának meghatározását a fejezet végén fogom ismertetni.

Az UV spektrumokon egy ekvivalens $\mathrm{Hg}^{2+}$-ion hozzáadására a 200-300 nm-es hullámhossz tartományban már savas körülmények között is szignifikáns eltérés mutatkozik a szabad PP ligandum abszorbanciájához képest (5.3.1.1. ábra).

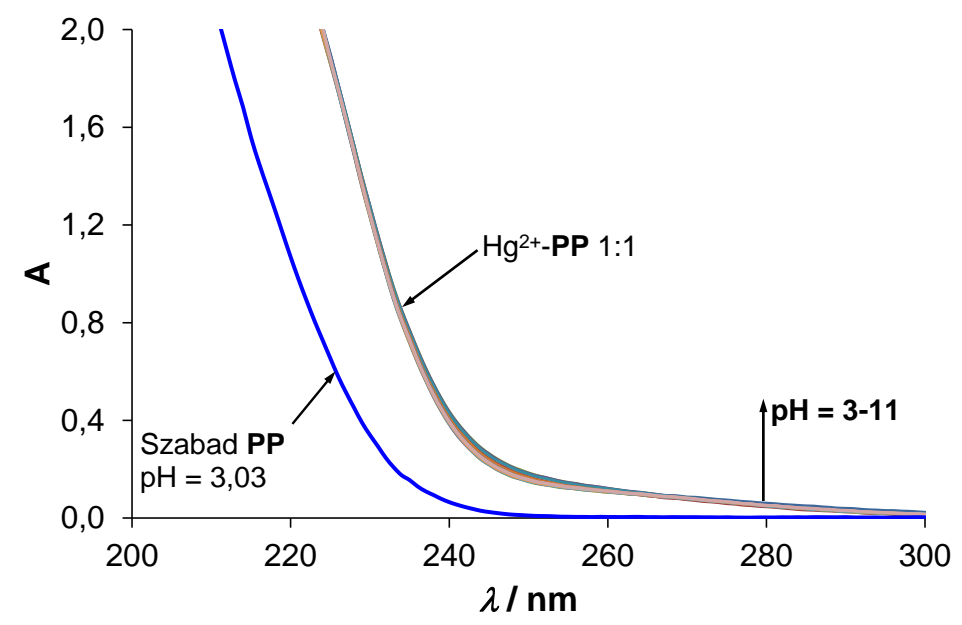

5.3.1.1. ábra: $\mathrm{Hg}^{2+}$-PP $1: 1$ fémion:ligandum arányú rendszer $\mathrm{pH}$-függő $\mathrm{UV}$ spektrumai összehasonlítva a szabad ligandummal $\left(c_{\mathbf{P P}}=1,0 \times 10^{-4} \mathrm{M}, I=0,1 \mathrm{M} \mathrm{NaClO}_{4}, l=10 \mathrm{~mm}, T=298 \mathrm{~K}\right)$

A $\mathrm{Hg}^{2+}$-PP 1:1 fémion:ligandum arányú rendszer csaknem állandó abszorbanciát mutat $\lambda=230 \mathrm{~nm}$-en [52, 120, 123, 124], pH 3-11 között (5.3.1.2. ábra), ami arra utal, hogy a savas közegben kialakult komplex van jele a vizsgált pH tartományban.

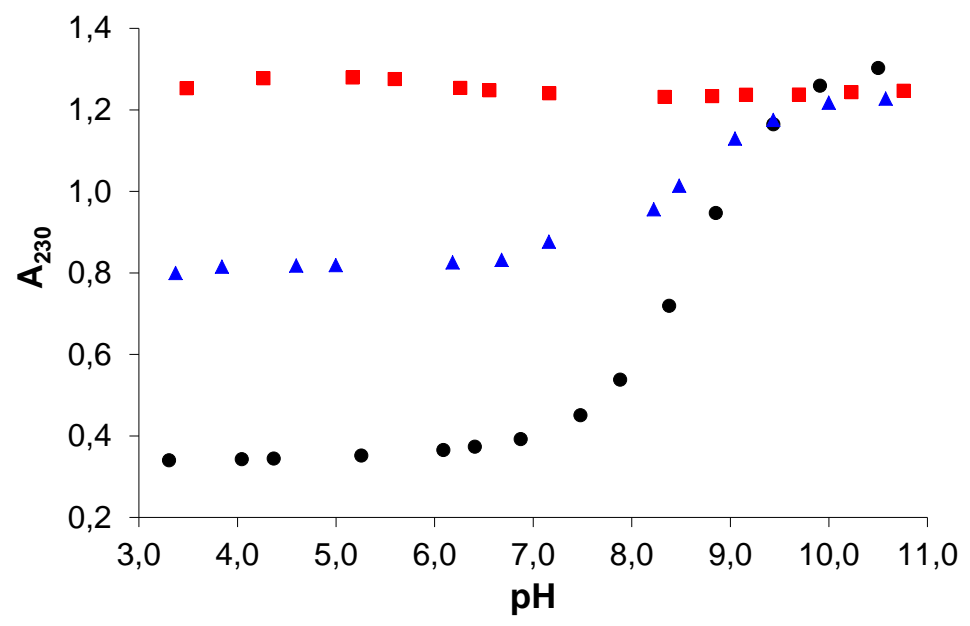

5.3.1.2. ábra: Különböző $\mathrm{Hg}^{2+}-\mathbf{P P}$ fémion:ligandum arányú rendszerek $\mathrm{A} v s$. pH görbéje összehasonlítva a szabad ligandummal. $\bullet:$ Szabad PP, $\mathbf{\Delta}: \mathrm{Hg}^{2+} \mathbf{- P P} 0,5: 1, \mathbf{\square}: \mathrm{Hg}^{2+}-\mathbf{P P} 1: 1$

$$
\left(c_{\mathbf{P P}}=1,0 \times 10^{-4} \mathrm{M}, I=0,1 \mathrm{M} \mathrm{NaClO}_{4}, l=10 \mathrm{~mm}, T=298 \mathrm{~K}\right)
$$


A szabad PP A vs. pH görbéjén, pH 8-10 közötti abszorbancia növekedés az 5.1.2 fejezetben tárgyaltak alapján, a tiolcsoportok deprotonálódásának következményeként megjelenő $\mathrm{n} \rightarrow \sigma^{*}$ átmenethez rendelhető [118, 119]. Ez szintén hiányzik a $\mathrm{Hg}^{2+}-\mathbf{P P}$ görbéről, amely megerősíti, hogy a $\mathrm{Hg}^{2+}$-ion $\left\{2 \times \mathrm{S}^{-}\right\}$típusú koordinációban vesz részt.

A spektrofotometriás vizsgálatokat ligandumfelesleg alkalmazása mellett is megismételtük. Kíváncsiak voltunk arra, vajon kialakul-e lineáris geometriájú részecskétől eltérő komplex, mint például a MerR higany-specifikus szabályzó fehérjére jellemző trigonális, $\mathrm{a} \mathrm{Hg}^{2+}$ koordináció szférájában három tiolátcsoportot tartalmazó részecske [51], esetleg egyéb, magasabb koordinációs számú komplex [75, 77, 78, 89, 90]. Mindegyik peptid két ekvivalensének jelenléte mellett a tiolcsoportok deprotonálódása két lépésben történt meg (5.3.1.3. ábra).

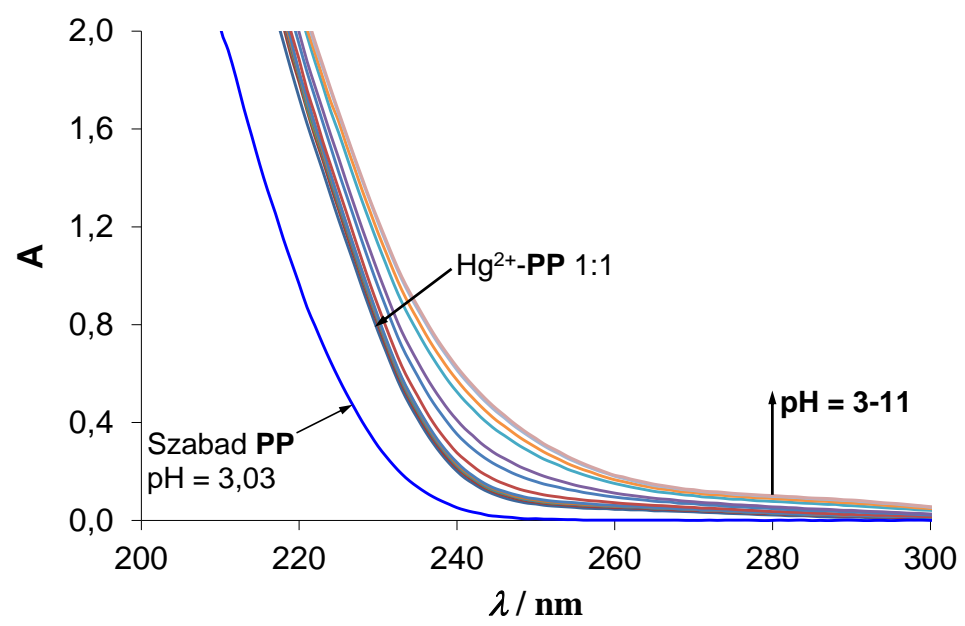

5.3.1.3. ábra: $\mathrm{Hg}^{2+}-\mathbf{P P} 0,5: 1$ fémion:ligandum arányú rendszer $\mathrm{pH}$ függő $\mathrm{UV}$ spektrumai összehasonlítva a szabad ligandummal $\left(c_{\mathbf{P P}}=1,0 \times 10^{-4} \mathrm{M}, I=0,1 \mathrm{M} \mathrm{NaClO}_{4}, l=10 \mathrm{~mm}, T=298 \mathrm{~K}\right)$

Az abszorbanciák is eltérnek a szabad ligandum spektrumaitól savas körülmények között, azonban az 1:1 arányú komplexnél mértnél kisebbek. A pH = 7,5-9,5 tartományban az A vs. pH görbe növekedést mutat (5.3.1.2. ábra), hasonlóan a fémion távollétében mért szabad PP A vs. pH görbéjéhez. Ebből arra következtetünk, hogy a semleges pH eléréséig a ciszteinek $\sim 50 \%$-a kötődik a $\mathrm{Hg}^{2+}$-ionokhoz, majd a tiolcsoportok a szabad ligandumnál tapasztalt pH-tartományban, fémionhoz kötődés nélkül deprotonálódnak. Hasonló eredményekre jutottunk a PS és EC peptidek $\mathrm{Hg}^{2+}$-komplexeinek vizsgálata során is (F40F41. ábra).

Az UV spektroszkópiai eredmények alapján sikerült bizonyítanunk a Cys tiolátcsoportok koordinálódását. A ligandum további, koordinatív kötések kialakítására alkalmas donorcsoportjainak tanulmányozásához ${ }^{1} \mathrm{H}$ NMR spektroszkópiát alkalmaztunk. A $\mathrm{Hg}^{2+}$-PP komplex 1:1 fémion:ligandum arányú rendszerében mért spektrumokat a szabad 
ligandum azonos pH-n mért spektrumaival összevetve legjelentősebb eltérés a Cys egységek $\mathrm{C}_{\beta} \mathrm{H}_{2}$ jelein figyelhető meg (5.3.1.4. ábra). Fémion jelenlétében az említett rezonanciák 0,3-0,5 ppm-mel az alacsonyabb terek irányába tolódnak, ami már a $\mathrm{pH}=1,91$ értéknél felvett spektrumról is elmondható.

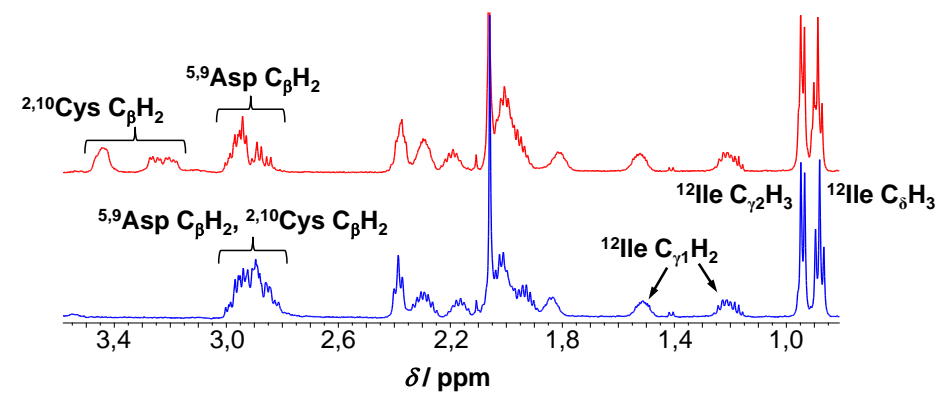

5.3.1.4. ábra: $\mathrm{A} \mathrm{Hg}^{2+}$-PP $1: 1$ fémion:ligandum arányú rendszerben felvett ${ }^{1} \mathrm{H}$ NMR spektrumok részlete az alifás hidrogének tartományában. Kék: szabad PP, Piros: $\mathrm{Hg}^{2+}-\mathbf{P P}$ 1:1

$\left(c_{\mathbf{P P}}=1,3 \times 10^{-3} \mathrm{M}, \mathrm{H}_{2} \mathrm{O} / \mathrm{D}_{2} \mathrm{O}=90 / 10 \% \mathrm{v} / \mathrm{v}, I=0,1 \mathrm{M} \mathrm{NaClO}_{4}, \mathrm{pH}=1,91, T=298 \mathrm{~K}\right)$

Ez egyértelmü jele a két tiolátcsoport koordinációjának már savas körülmények között is. Ugyanakkor a többi aminosavhoz tartozó $\mathrm{C}_{\beta} \mathrm{H}_{2}$ jelek gyakorlatilag nem változnak. Továbbá a $\mathrm{Zn}^{2+}$-, és $\mathrm{Cd}^{2+}$-ionok peptidkomplexeinél tapasztalt vonalszélesedéssel szemben a koordinálódó Cys jelein kívül nem tapasztaltuk a jelek jelentősebb szélesedését. Ez azt igazolja, hogy a vizsgált pH-tartományban egyetlen uralkodó részecske van jelen, valamint a ligandum konformáció-változásának a sebessége nem változott jelentősen fémion hozzáadása után sem.

A két Asp $\mathrm{C}_{\beta} \mathrm{H}_{2}$ jeleinek pH függő változása (5.3.1.1.5. ábra) megegyezik a szabad ligandumnál tapasztalt karboxilcsoport-deprotonálódás által okozott kémiai eltolódás változással (F9. ábra), tehát ezek a csoportok nem vesznek részt a koordinációban.

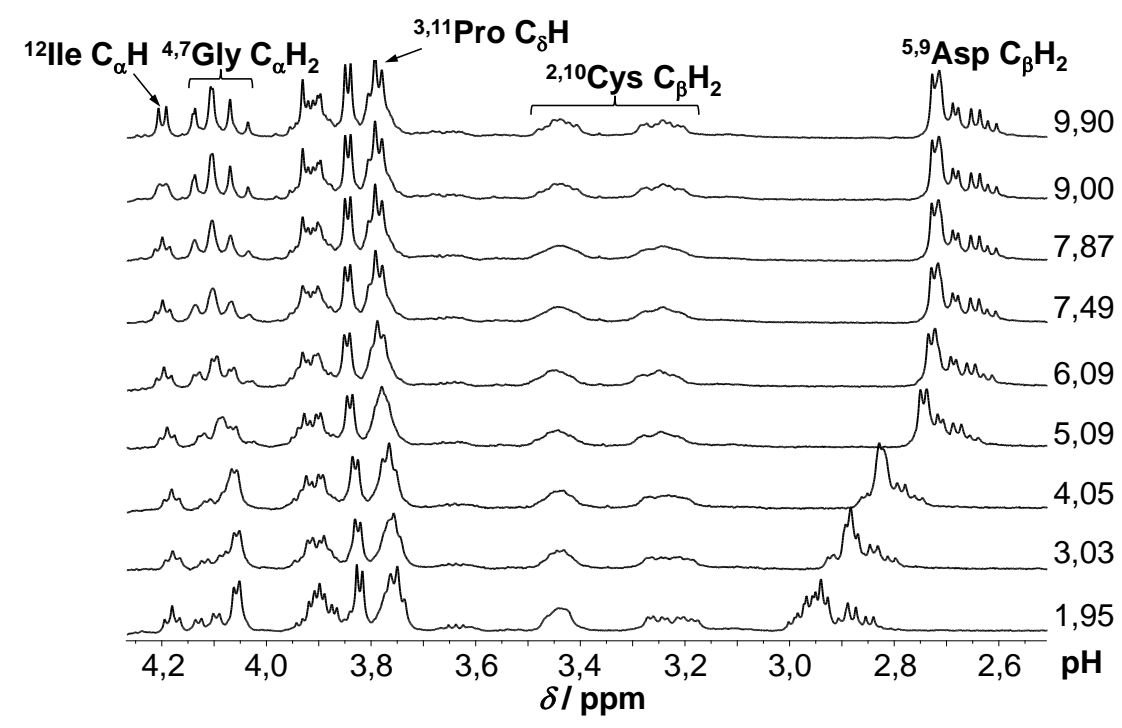

5.3.1.5. ábra: $\mathrm{A} \mathrm{Hg}^{2+}$-PP $1: 1$ fémion:ligandum arányú rendszer $\mathrm{pH}$-függö ${ }^{1} \mathrm{H}$ NMR spektrumainak részlete az alifás hidrogének tartományában $\left(c_{\mathbf{P P}}=1,3 \times 10^{-3} \mathrm{M}, \mathrm{H}_{2} \mathrm{O}_{2} \mathrm{D}_{2} \mathrm{O}=90 / 10 \% \mathrm{v} / \mathrm{v}, I=0,1 \mathrm{M} \mathrm{NaClO}_{4}, T=298 \mathrm{~K}\right)$ 
Ligandumfelesleg jelenlétében szintén végeztünk ${ }^{1} \mathrm{H} \quad \mathrm{NMR}$ vizsgálatokat. $\mathrm{pH}<3$ mellett az 1:1 arányú rendszerre jellemző széles jeleket $(\delta=3,15-3,50 \mathrm{ppm})$ láthatjuk (5.3.1.6. ábra). A pH növelésével az Asp karboxilcsoportjai koordinálódás nélkül deprotonálódnak, ami az Asp jelek eltolódását eredményezi. Ez miatt elkülönülnek az Asp és Cys $\mathrm{C}_{\beta} \mathrm{H}_{2}$ rezonanciák (lásd szabad $\mathbf{P P}$ pH-függő $1 \mathrm{H}$ NMR spektrumai, F9. ábra), így láthatóvá válik a $\delta=2,80-3,00$ ppm közötti széles, azonban a szabad ligandum $\mathrm{Cys}^{\mathrm{C}_{\beta} \mathrm{H}_{2}}$ jeleihez nagyon hasonló jel. Lúgos körülmények között a szabad ciszteinhez rendelhető csúcs kiszélesedik, majd az alacsonyabb terek irányába tolódva összeolvad a kötött ciszteinekre jellemző $\mathrm{C}_{\beta} \mathrm{H}_{2}$ jelekkel. Az új jelcsoport ( $\delta=3,00-3,30$ ppm) a kötött és szabad Cys $\mathrm{C}_{\beta} \mathrm{H}_{2}$ rezonanciák között van. A folyamat hátterében álló okokról bővebben a hisztidintartalmú HS peptid $\mathrm{Hg}^{2+}$-komplexeinek tárgyalásakor lesz szó.

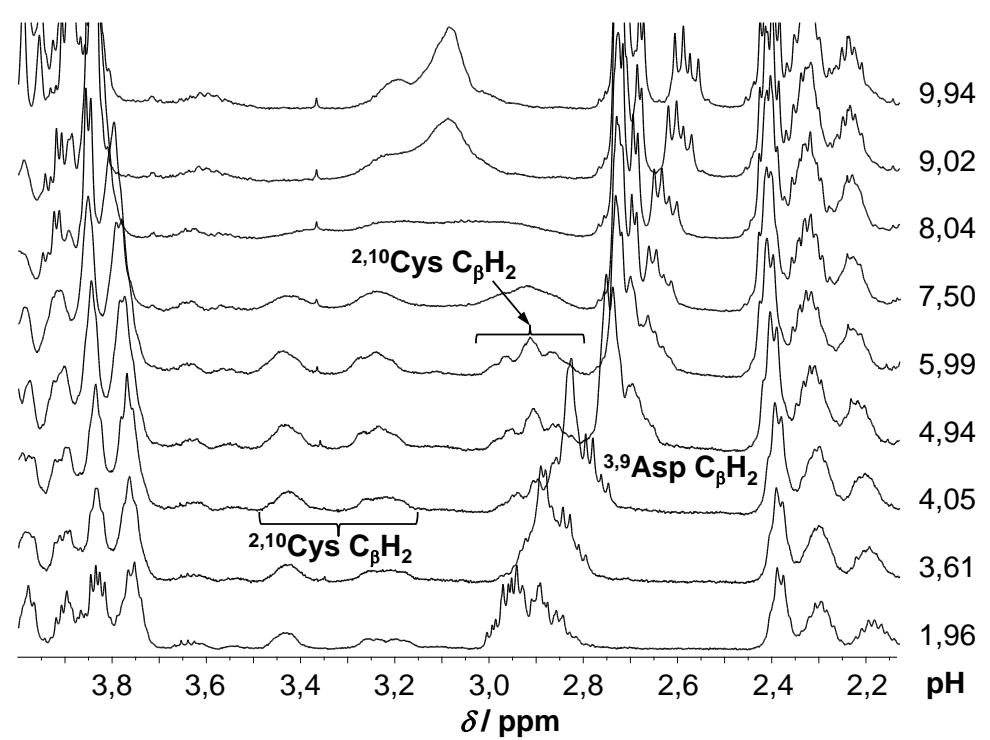

5.3.1.6. ábra: $\mathrm{A} \mathrm{Hg}^{2+}$-PP $0,5: 1$ rendszer $\mathrm{pH}$-függő ${ }^{1} \mathrm{H}$ NMR spektrumainak részlete az alifás hidrogének tartományában $\left(c_{\mathbf{P P}}=1,3 \times 10^{-3} \mathrm{M}, \mathrm{H}_{2} \mathrm{O} / \mathrm{D}_{2} \mathrm{O}=90 / 10 \% \mathrm{v} / \mathrm{v}, I=0,1 \mathrm{M} \mathrm{NaClO}_{4}, T=298 \mathrm{~K}\right)$

A $\mathrm{Hg}^{2+}$-PP komplex kialakulása részben rögzíti a szerkezetet, a peptid két végén elhelyezkedő ciszteineken keresztül, egy hurok kialakításával. A szabad ligandumnál tapasztalt mozgás így jóval korlátozottabb lesz, de a fémion-kötő hurok még mindig elég nagyméretű ahhoz, hogy konformációs átalakulások játszódhassanak le. Ezt CD spektroszkópiai mérésekkel is tudtuk igazolni. Szembetűnő, hogy a kötött ligandumban a $\lambda$ 200 nm-nél megfigyelhető sáv intenzitása lényegesen lecsökken a szabad formához képest (5.1.4. fejezet). Megfigyelhető továbbá, hogy az aszparaginsavak deprotonálódását jelentős változás kíséri a $\mathrm{CD}$ spektrumon (5.3.1.7. ábra). Ezen deprotonálódási folyamatokat követően azonban a spektrum jelentősen már nem változik, hiszen a tiolcsoportok már deprotonáltak. 
Az elöbbi jelenség annak tudható be, hogy a két karboxilát-ion negatív töltései a két végén rögzített peptidmolekulán alakultak ki, így ezen csoportok taszítása jobban érvényesül a konformációs átalakulások során, mint a szabad peptidben. Ebből adódóan megváltozik a különböző konformerek egymáshoz viszonyított eloszlása.

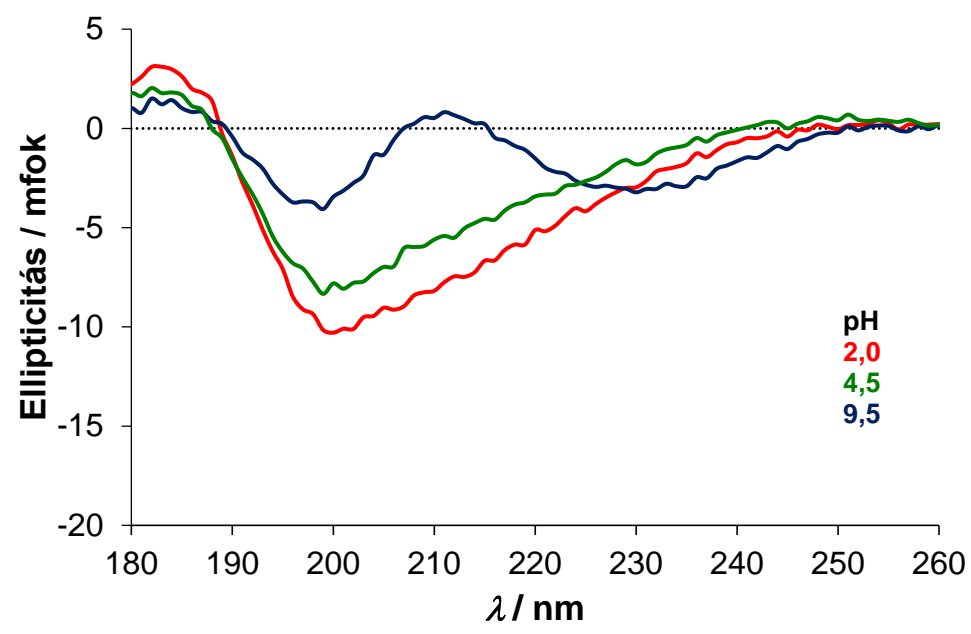

5.3.1.7. ábra: $\mathrm{A} \mathrm{Hg}^{2+}$-PP $1: 1$ arányú rendszer $\mathrm{pH}$-függő $\mathrm{CD}$ spektrumai $\left(c_{\mathbf{P P}}=1,0 \times 10^{-3} \mathrm{M}, l=0,1 \mathrm{~mm}, I=0,1 \mathrm{M} \mathrm{NaClO}_{4}, T=298 \mathrm{~K}\right)$

A fentiek hatása a $\mathrm{Hg}^{2+}$-PP 1:1 fémion:ligandum arányú $\mathrm{pH}$ függő $\mathrm{NMR}$ spektrumsorozatán is látható (5.3.1.5. ábra). Az aszparaginsavak deprotonálódásával párhuzamosan jelentősen megváltozik például a glicin aminosavak $\mathrm{C}_{\alpha} \mathrm{H}_{2}$ jele. Ez a változás utalhat arra, hogy két Asp oldalláncának deprotonálódását kísérő negatív töltéstöbblet megváltoztatja a peptid gerincében a diéderes szögeket. Ez összhangban van a CD spektrumokon megfigyelhető, az Asp deprotonálódását kísérő változásokkal. Mivel a konformációs átalakulások az NMR spektroszkópia időskálájához viszonyítva gyorsak, ezért a konformációkra jellemző rezonanciák kiátlagolt jeleit látjuk a spektrumokon. 
Az eddigi spektroszkópiai vizsgálatok során a komplexképződést, illetve a kialakult komplexek szerkezetét a fémion ligandumra gyakorolt hatásán keresztül vizsgálhattuk. Azonban lehetöségünk nyílt arra, hogy egy együttmüködés keretein belül (Lars Hemmingsen, University of Copenhagen) PAC spektroszkópia alkalmazásával a koordinálódó ligandum hatását figyelhessük meg a $\mathrm{Hg}^{2+}$-ionokon. A vizsgálatok kivitelezésére a svájci CERN-ben (Európai Nukleáris Kutatási Szervezet) került sor. A mérések során kapott spektrumok illesztési paraméterei az 5.3.1.1. táblázatban láthatók.

\begin{tabular}{lccccc}
\hline Rendszer (pH) & $\begin{array}{c}\boldsymbol{v}_{\mathbf{Q}}(\mathbf{G H z}) \\
(\mathbf{S D})\end{array}$ & $\boldsymbol{\eta}(\mathbf{S D})$ & $\begin{array}{c}\text { Koordinációs } \\
\text { környezet }\end{array}$ & Referencia \\
\hline $\mathrm{Hg}^{2+}$-PP $1: 1$ & $(9,5)$ & $1,42(4)$ & $0,13(6)$ & $\left\{2 \times \mathrm{S}^{-}\right\}$ & Jelen munka \\
$\mathrm{Hg}^{2+}$-PP $1: 1$ & $(6,0)$ & $1,36(2)$ & $0,18(5)$ & $\left\{2 \times \mathrm{S}^{-}\right\}$ & Jelen munka \\
$\mathrm{Hg}^{2+}$-PP $0,5: 1(6,0)$ & $1,42(2)$ & $0,13(5)$ & $\left\{2 \times \mathrm{S}^{-}\right\}$ & Jelen munka \\
$\mathrm{Hg}^{2+}$-PP $0,5: 1(9,4)$ & $1,41(1)$ & $0,18(3)$ & $\left\{2 \times \mathrm{S}^{-}\right\}$ & Jelen munka \\
$\mathrm{Hg}^{2+}$-HS $1: 1$ & $(2,0)$ & $1,43(5)$ & $0,07(6)$ & $\left\{2 \times \mathrm{S}^{-}\right\}$ & Jelen munka \\
$\mathrm{Hg}^{2+}$-HS $1: 1$ & $(8,0)$ & $1,43(1)$ & $0,13(3)$ & $\left\{2 \times \mathrm{S}^{-}\right\}$ & Jelen munka \\
$\mathrm{Hg}(\mathrm{Cys})_{2}$ & 1,41 & 0,15 & $\left\{2 \times \mathrm{S}^{-}\right\}$ & {$[125]$} \\
$\mathrm{MerR}(77 \mathrm{~K})$ & 1,18 & 0,25 & $\left\{3 \times \mathrm{S}^{-}\right\}$ & {$[126]$} \\
$\mathrm{Hg}-\mathrm{Rubredoxin}$ & 0,10 & 0 & $\left\{4 \times \mathrm{S}^{-}\right\}$ & {$[127]$} \\
\hline
\end{tabular}

5.3.1.1. táblázat: $\mathrm{Az}$ általunk vizsgált peptidek $\mathrm{Hg}^{2+}-\mathrm{komplexeinek} \mathrm{fontosabb} \mathrm{PAC}$ paraméterei és a fémion javasolt koordinációs környezete összehasonlítva más Cys-tartalmú $\mathrm{Hg}^{2+}$-komplexek paramétereivel

Az ekvimoláris rendszerekben mért spektrumok viszonylag jól illeszthetők olyan részecskéket jellemző paraméterekkel, melyben a $\mathrm{Hg}^{2+}$-centrumhoz két Cys tiolátcsoportja koordinálódik (5.3.1.8. ábra).
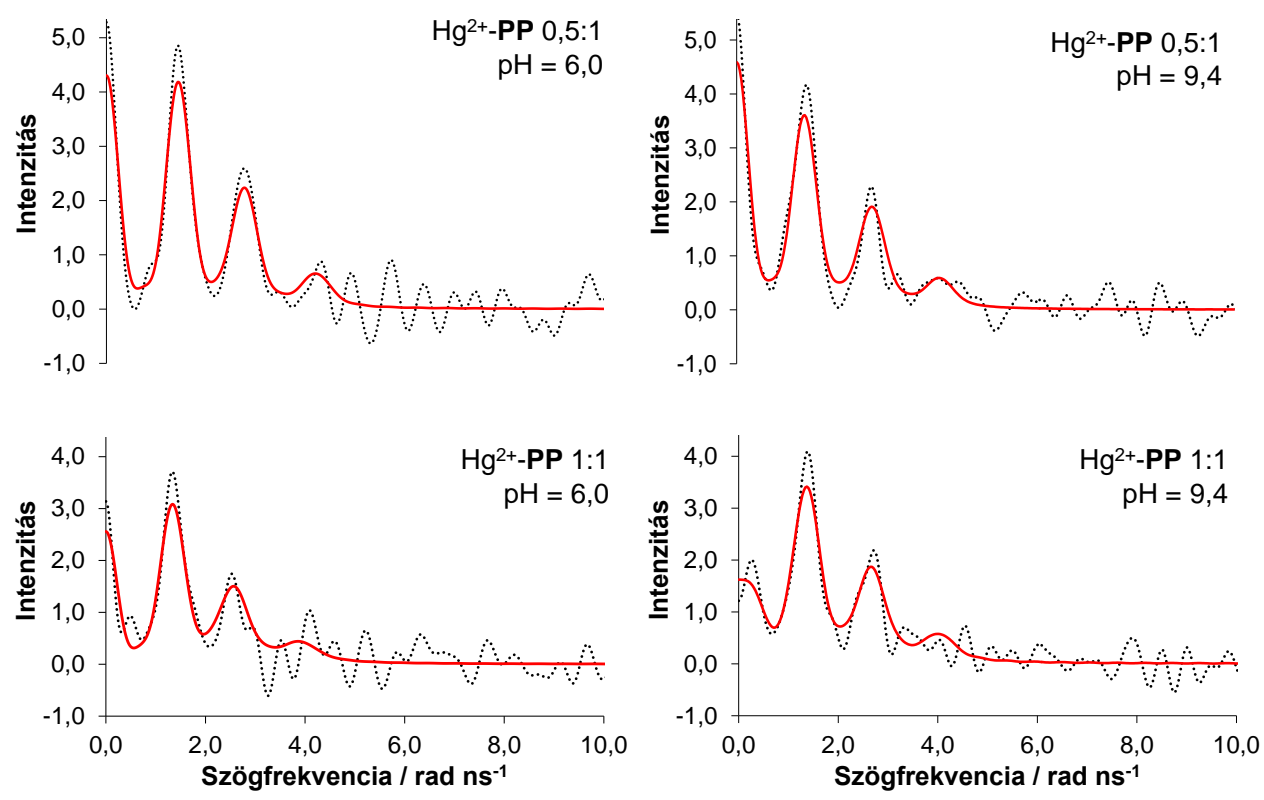

5.3.1.8. ábra: $\mathrm{Hg}^{2+}$-PP különböző fémion:ligandum arányú rendszerek $P A C$ spektrumai. A kísérleti adatok Fourier-transzformáltjai (fekete szaggatott vonal), illetve azok illesztése (piros vonal) 
Ilyen például a Butz és munkatársai által vizsgált $\mathrm{Hg}^{2+}(\mathrm{Cys})_{2}$ komplex is. Ligandumfelesleg mellett is végeztünk PAC méréseket, hogy kiderítsük, vajon lehetséges-e kettőnél több tiolátcsoport kötődése a fémionhoz, azonban az ekvimoláris rendszerben végzett mérésekhez nagyon hasonló eredményeket kaptunk.

A PAC eredmények, valamint az ${ }^{1} \mathrm{H}$ NMR és az UV-mérések alapján megállapítható, hogy $\mathrm{Hg}^{2+}$-ionokkal nem tapasztalható biszkomplexek képződése, továbbá az Asp karboxilátcsoportjai sem vesznek részt a koordinációban. A vizsgált pH-tartományban $\left\{2 \times \mathrm{S}^{-}\right\}$típusú monokomplexek dominálnak. A PP ligandum mellett a PS, illetve az EC peptidet vizsgálva is hasonló spektrális változásokat tapasztaltunk (F42-F44. ábra).

Nem zárható ki azonban többmagvú komplexek kialakulása. A PP peptidet $\mathrm{Hg}^{2+}-$ ionokkal titrálva a szabad $\mathrm{Cys} \mathrm{C}_{\beta} \mathrm{H}_{2}$ jeleinek intenzitása az 1:1 fémion:ligandum arány eléréséig fokozatosan csökken (5.3.1.9. ábra).

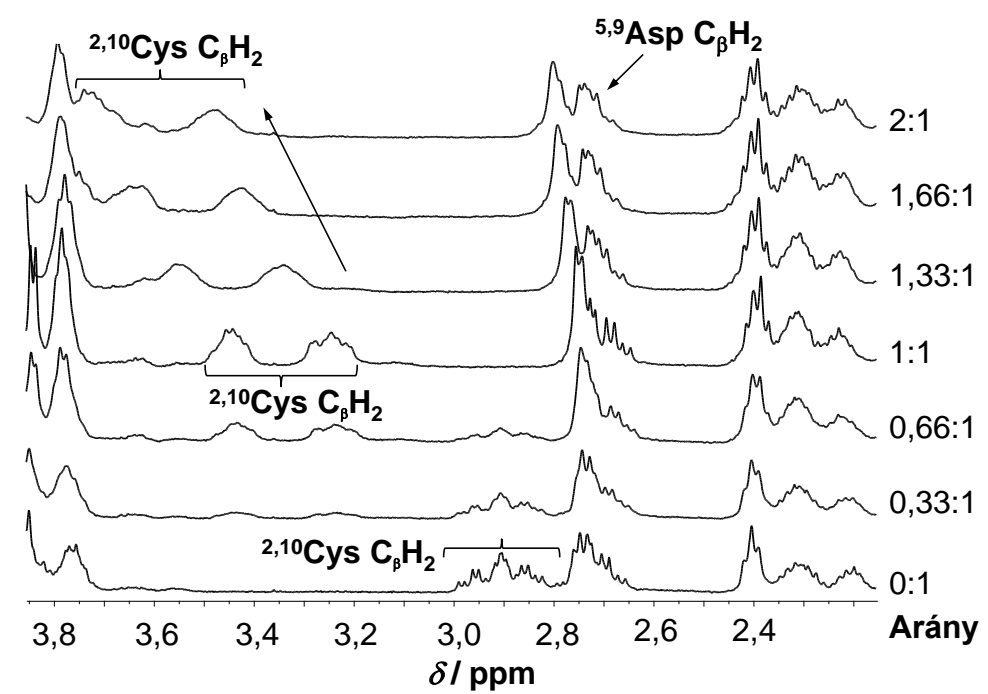

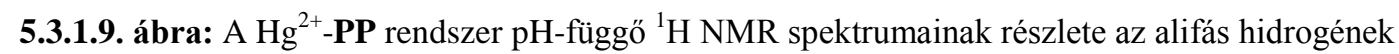
tartományában. $\left(c_{\mathbf{P P}}=1,3 \times 10^{-3} \mathrm{M}, \mathrm{H}_{2} \mathrm{O} / \mathrm{D}_{2} \mathrm{O}=90 / 10 \% \mathrm{v} / \mathrm{v}, I=0,1 \mathrm{M} \mathrm{NaClO}_{4}, \mathrm{pH}=5,0, T=298 \mathrm{~K}\right.$,

Ezzel párhuzamosan $\delta=3,2-3,5$ ppm-nél új jelcsoport fejlődik ki. Ezt követően további $\mathrm{Hg}^{2+}$-ion hozzáadására a kötött $\mathrm{Cys} \mathrm{C}_{\beta} \mathrm{H}_{2}$ jelek alacsonyabb terek felé történő fokozatos eltolódása többmagvú komplexek kialakulására utal. Ennek bizonyítására PAC spektrumokat vettünk fel 2:1 fémion:ligandum arány mellett (ilyen méréseket a PS és HS peptiddel végeztünk).

A PAC spektroszkópiával elvi lehetőség van arra, hogy egyszerre több különböző koordinációs környezetben lévő fémionról szerezzünk információt, ugyanis az eltérő fémcentrumokat tartalmazó részecskék jelei elvileg eltérő paraméter együttessel $\left(v_{\mathrm{Q}}\right.$ és $\left.\eta\right)$ jellemezhetők, azaz a PAC spektrumok akár több részecske jeleinek szuperpozíciójaként is illeszthetők. 
A megfigyelt csúcsok intenzitásainak aránya utal a fémion megoszlására a különböző koordinációs környezetek között. Savas körülmények között $(\mathrm{pH}=2,0)$ 2:1 $\mathrm{Hg}^{2+}:$ PS arány esetén a kísérleti eredményeket sem egy, sem két részecske feltételezésével nem tudtuk elfogadhatóan megilleszteni. Ennek értelmezésére a $\mathrm{Hg}^{2+}-\mathbf{H S}$ rendszer tárgyalásánál fogok kitérni. A lúgos körülmények között $(\mathrm{pH}=9,9)$ a mért spektrumok alakja (5.3.1.10. ábra) nagy hasonlóságot mutat az 1:1 arányú rendszerekben $\mathrm{pH}=2,0$-nál mérttel.
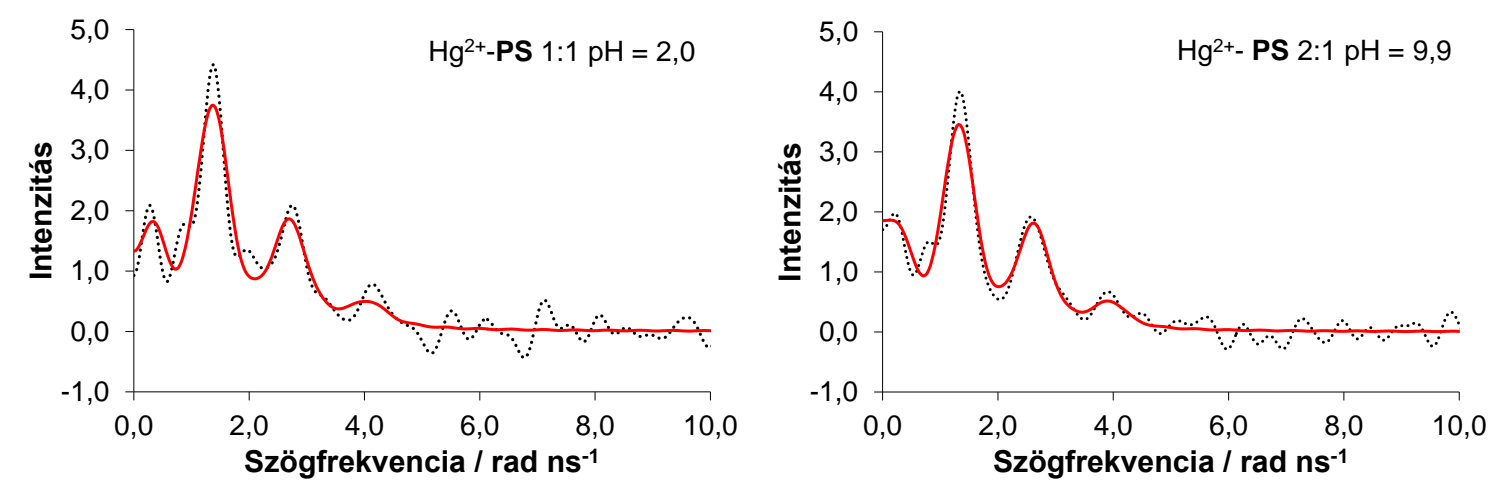

5.3.1.10. ábra: $\mathrm{Hg}^{2+}$-PS 2:1 fémion:ligandum arányú rendszer PAC spektruma összehasonlítva az $1: 1$ arányú rendszer spektrumával. A kísérleti adatok Fourier-transzformáltjai (fekete szaggatott vonal), illetve azok illesztése (piros vonal)

Az illesztés savas pH-hoz képest egy komponens feltételezésével is jónak mondható, a meghatározott paraméterek azonban kis mértékben eltérnek az 1:1 komplexre meghatározottaktól (5.3.1.2. táblázat).

\begin{tabular}{|c|c|c|c|}
\hline Rendszer (pH) & $\mathrm{v}_{\mathrm{Q}}(\mathrm{GHz})(\mathrm{SD})$ & $\eta(\mathrm{SD})$ & $\begin{array}{c}\text { Koordinációs } \\
\text { környezet }\end{array}$ \\
\hline $\mathrm{Hg}^{2+}-\mathbf{P S} \quad 1: 1(2,0)$ & $1,44(1)$ & $0,08(6)$ & $\left\{2 \times \mathrm{S}^{-}\right\}$ \\
\hline $\mathrm{Hg}^{2+}$-PS $\quad 2: 1(9,9)$ & $1,39(1)$ & $0,01(5)$ & $?$ \\
\hline $\mathrm{Hg}^{2+}-\mathbf{H S} \mathbf{S}^{\mathbf{a}} 2: 1(2,0)$ & $1,43(0)$ & $0,13(1)$ & $\left\{2 \times S^{-}\right\}$ \\
\hline $\mathrm{Hg}^{2+}-\mathbf{H S}^{\mathbf{b}} 2: 1(2,0)$ & $0,68(5)$ & $0,41(11)$ & $?$ \\
\hline $\mathrm{Hg}^{2+}-\mathbf{H S} \quad 2: 1(10,3)$ & $1,38(1)$ & $0,20(2)$ & $?$ \\
\hline
\end{tabular}

5.3.1.2. táblázat: Az általunk vizsgált peptidek $\mathrm{Hg}^{2+}-$ komplexeinek fontosabb $P A C$ paraméterei és a fémion javasolt koordinációs környezete

Amint azt már a 4.8. fejezetben kifejtettem, az illesztések során kapott paraméterekből nem lehet egyértelműen kijelenteni, milyen donorcsoportok kötődnek a fémionokhoz, azonban a koordinálódó csoportok száma feltételezhető. Ezek alapján lúgos körülmények között elképzelhető egy olyan, két fémcentrumot tartalmazó szerkezet 
kialakulása, amelyben a szeparált $\mathrm{Hg}^{2+}$-centrumokhoz 1-1 tiolátcsoport és 1-1 hidroxidion koordinálódik.

A PAC mérések során tapasztalt pH-függő változások a $\mathrm{CD}$ spektrumokon is láthatók, ugyanis fémion felesleg jelenlétében $\mathrm{pH}=6,5$ felett jelentős $\mathrm{CD}$-effektus-változást látunk (5.3.1.11. ábra).

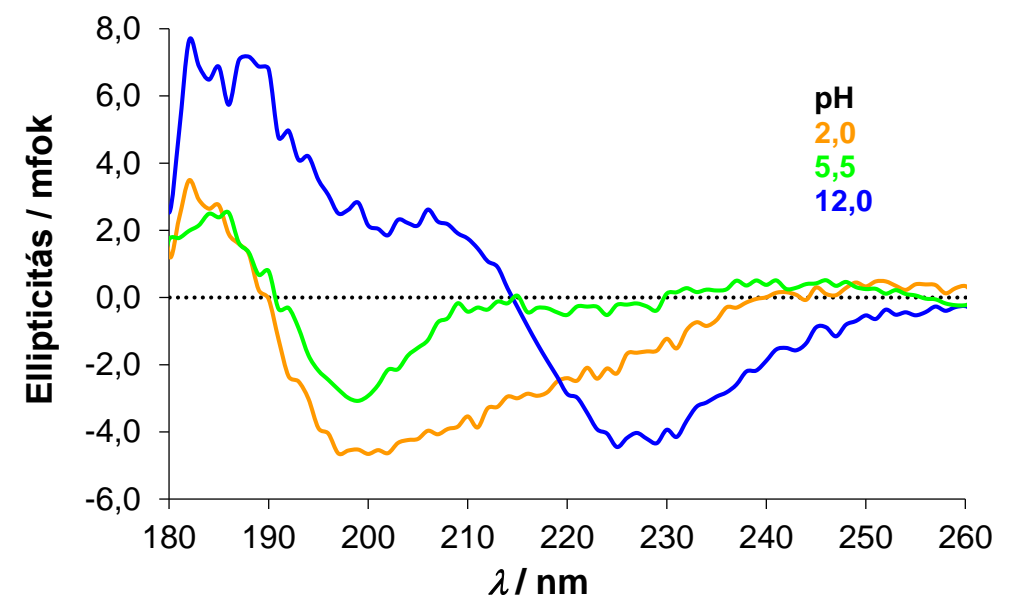

5.3.1.11. ábra: $\mathrm{A} \mathrm{Hg}^{2+}-\mathbf{P S} 2: 1$ fémion:ligandum arányú rendszer $\mathrm{CD}$ spektrumai különböző $\mathrm{pH}$ értékeknél.

$$
\left(c_{\mathbf{P S}}=1,0 \times 10^{-3} \mathrm{M}, I=0,1 \mathrm{M} \mathrm{NaClO}_{4}, l=0,1 \mathrm{~mm}, T=298 \mathrm{~K}\right)
$$

Továbbá a $\mathrm{pH}=12-n$ felvett spektrumok időbeli változást mutatnak, melyek jellege alapján úgy tünik, hogy az ekvimoláris rendszerre jellemző spektrum kezd kialakulni (5.3.1.12. ábra).

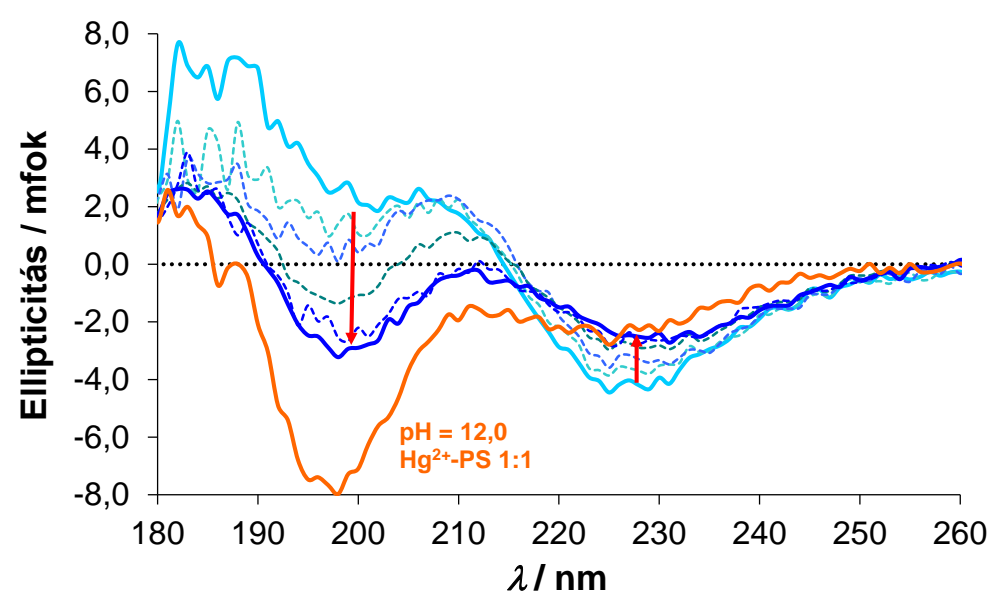

5.3.1.12. ábra: $\mathrm{A} \mathrm{Hg}^{2+}$-PS 2:1 fémion:ligandum arányú rendszer $\mathrm{CD}$ spektrumai különbözö pH értékeknél $\left(c_{\mathbf{P S}}=1,0 \times 10^{-3} \mathrm{M}, I=0,1 \mathrm{M} \mathrm{NaClO}_{4}, l=0,1 \mathrm{~mm}, T=298 \mathrm{~K}\right)$

Ez a változás feltehetőleg azzal magyarázható, hogy a kezdetben létrejövő 2:1 összetételü komplexből az egyik fémion lassan hidrolízis termék képződése közben távozik, s így kialakul a magas pH-ra jellemző 1:1 összetételü komplex. Az ábrák alapján az is egyértelmü, hogy a 2:1 arányú rendszerben a ligandum konformációja jelentősen különbözik az 1:1 arányú mintához képest, ami eltérő szerkezetű komplexek képződését jelentheti. 
Az itt kapott eredmények az NMR és PAC mérésekkel egyezően azt mutatják, hogy fémionfelesleg mellett számítanunk kell többmagvú komplexek képződésére, melyek szerkezete és összetétele a közeg pH-jától függően változhat.

Szerkezetvizsgáló módszerekkel igazoltuk, hogy a $\mathrm{Hg}^{2+}$-ion rendkívül stabilis komplexet képez az általunk vizsgált cisztein-tartalmú peptidekkel. Ilyen esetben kvantitatív információ a kialakuló komplexek stabilitására vonatkozóan csak közvetett módszerrel nyerhető. Ezért a $\mathrm{Hg}^{2+}$-PS rendszerben ligandum kiszorításos módszert alkalmaztunk. Ezen

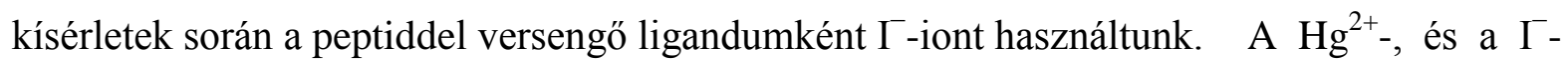
ion közötti komplexképződés már régóta ismert, így a $\mathrm{Hg}^{2+}-\mathrm{I}^{-}$, ill. $\mathrm{Hg}^{2+}-\mathrm{Cl}^{-}$rendszerekben kialakuló komplexekre az irodalomból ismert stabilitási állandókat használtuk fel (5.3.1.3. táblázat). Az adatok alapján a PSEQUAD programmal szimulálható részecskeeloszlás a szabad jodidionok koncentrációjának függvényében az 5.3.1.14. ábrán látható.

\begin{tabular}{cl}
\hline Halogenokomplex & \multicolumn{1}{c}{$\lg \boldsymbol{\beta}$} \\
\hline$[\mathrm{HgI}]^{+}$ & $12,87(3)$ \\
$\mathrm{HgI}_{2}$ & $23,82(4)$ \\
{$\left[\mathrm{HgI}_{3}\right]^{-}$} & $27,60(14)$ \\
{$\left[\mathrm{HgI}_{4}\right]^{2-}$} & $29,83(2)$ \\
{$\left[\mathrm{HgCl}^{+}\right.$} & $6,74(2)$ \\
$\mathrm{HgCl}_{2}$ & $13,22(2)$ \\
\hline
\end{tabular}

5.3.1.3. táblázat: A halogenokomplexekre vonatkozó stabilitási állandók [128, 129]

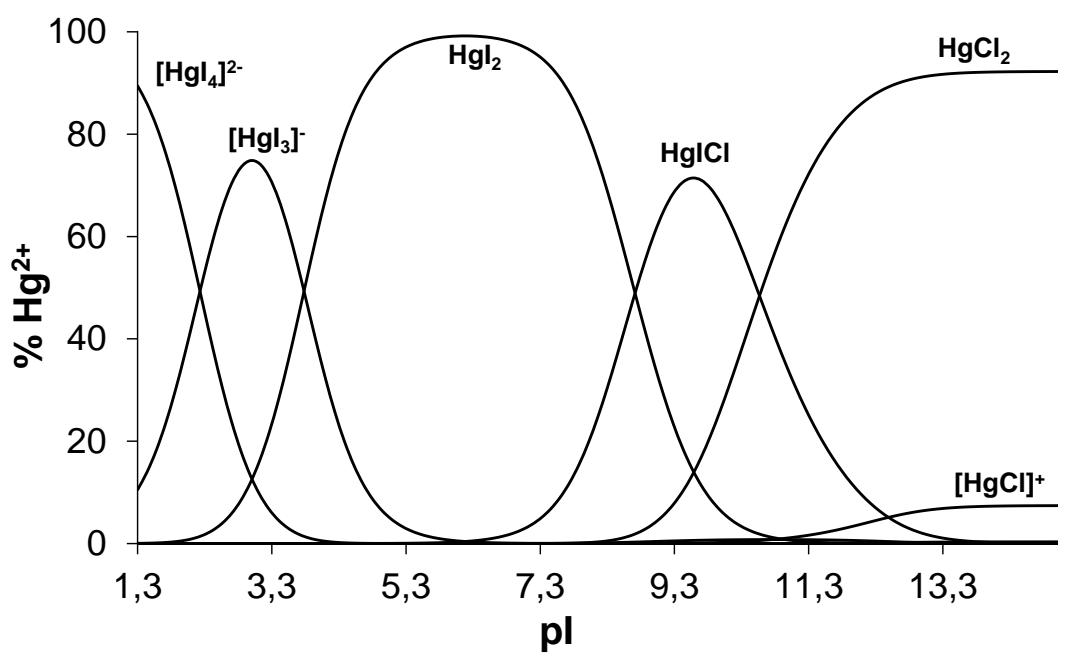

5.3.1.14. ábra: $\mathrm{Az}$ ismert $\lg \beta$ értékek alapján a $\mathrm{HgCl}_{2}$ - I rendszerben számolható eloszlási diagram a szabad jodidion koncentráció negatív logaritmusának függvényében [128, 129] 
Spektrofotometriás titrálásokat végeztünk úgy, hogy elöször a $\mathrm{HgCl}_{2}$-ot tartalmazó oldatot KI oldatával titráltuk a $\mathrm{c}_{\mathrm{I}}^{-}: \mathrm{c}_{\mathrm{Hg}^{2+}}$ arányt 0:1 és 2000:1 között változtatva (5.3.1.15. ábra baloldal). Az alkalmazott körülmények mellett három részecske elnyelése alakítja ki a spektrumsorozatot $\left(\left[\mathrm{HgI}_{4}\right]^{2-},\left[\mathrm{HgI}_{3}\right]^{-}\right.$és $\mathrm{HgI}_{2}, F 45$. ábra $)$. A nagy $\mathrm{I}^{-}$-ion felesleg mellett megfigyelhető két összetartozó izobesztikus pont az ilyen körülmények mellett fennálló $\left[\mathrm{HgI}_{3}\right]^{-}+\mathrm{I}^{-} \rightleftharpoons\left[\mathrm{HgI}_{4}\right]^{2-}$ egyensúlyra utal.
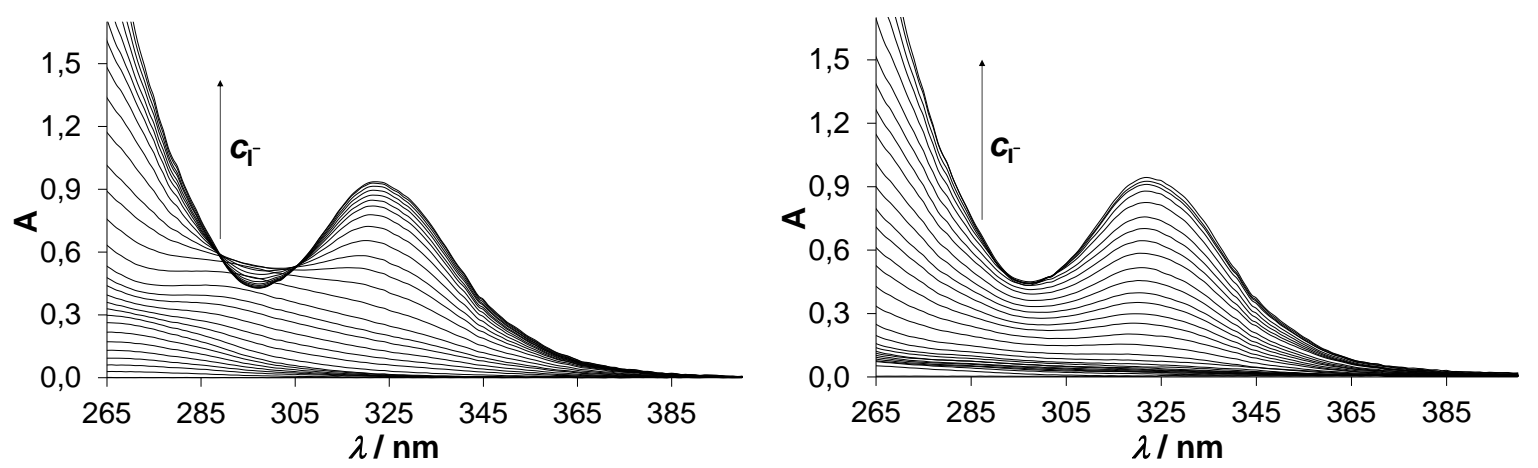

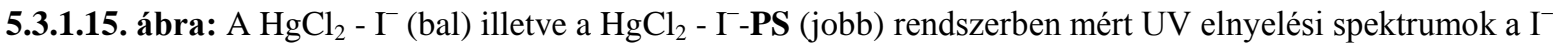
koncentrációjának növelésével $\left(c_{\mathrm{HgCl}_{2}}=5,1 \times 10^{-5} \mathrm{M}, I=0,1 \mathrm{M} \mathrm{NaClO}_{4}, \mathrm{pH}=2,0, T=298 \mathrm{~K}\right)$

A méréssorozatot $\mathrm{Hg}^{2+}$-ionokat és a PS peptidet 1:1 arányban tartalmazó oldatával is megismételtük (5.3.1.15. ábra jobb oldal). A két sorozat közötti különbség feltünő már kis $\mathrm{I}^{-}$-felesleg mellett, ugyanakkor a jodidion-koncentráció jelentős növelésével a spektrumok azonos lefutásúak mindkét rendszerben. Észrevehető az is, hogy a fentebb említett izobesztikus pontok jóval kevésbé egyértelműek, csak az utolsó spektrumoknál figyelhetők meg. Mindez arra utal, hogy a PS a fémion jodidionokkal történő komplexképződését erőteljesen befolyásolja (visszaszorítja), azonban kellően nagy $\mathrm{I}^{-}$-felesleggel a peptid kiszorítható a $\mathrm{Hg}^{2+}$-ionok koordinációs szférájából.

Ezt követően PSEQUAD program segítségével az ismert stabilitású és moláris spektrumú halgenokomplexekhez, egy L' összefoglaló képlettel leírható részecske spektrumát és stabilitási állandóját illesztettük. Ez egy olyan komplexet jelöl, melyben a ligandum bármilyen protonáltsági állapotban lehet, a meghatározott állandó pedig erre a részecskére és a mérések $\mathrm{pH}$-jára vonatkozó látszólagos stabilitási állandó. A moláris spektrumokból visszaszámolt abszorbanciák (5.3.1.12. ábra folytonos vonal) jó egyezést mutatnak az általunk mért abszorbancia értékekkel. 


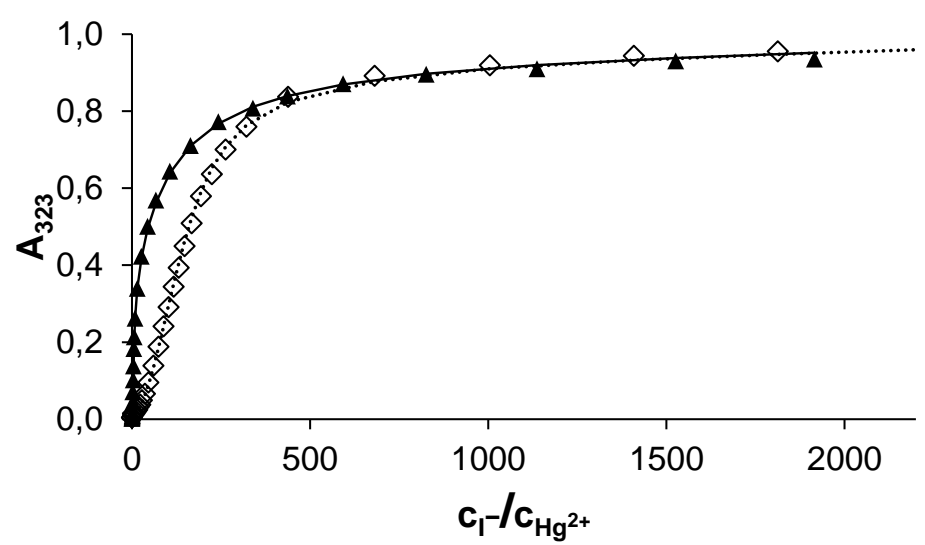

5.3.1.12. ábra: $\mathrm{A} \lambda=323 \mathrm{~nm}$-en ábrázolt abszorbancia értékek változása, ha a $\mathrm{HgCl}_{2}-\mathrm{t}(\boldsymbol{\Delta})$ vagy a $\mathrm{Hg}^{2+}-\mathbf{P S}$ 1:1 arányú rendszert $(\diamond)$ titráltuk KI oldattal. A folytonos vonal a PSEQUAD programmal számolt abszorbancia változást mutatja $\left(c_{\mathrm{HgCl}_{2}}=5,1 \times 10^{-5} \mathrm{M}, I=0,1 \mathrm{M} \mathrm{NaClO}_{4}, \mathrm{pH}=2,0, T=298 \mathrm{~K}\right)$

A komplexképződés folyamatát az alábbi egyenlet írja le:

$$
\begin{gathered}
\mathbf{L}^{\prime}+\mathrm{Hg}^{2+}(\mathrm{szabad})=\mathrm{Hg} \mathbf{L}^{\prime} \\
\lg \boldsymbol{K}^{\prime}=\mathbf{2 5 , 7}
\end{gathered}
$$

Az így kiszámolt $\lg K^{\prime}$ érték nagyon hasonló Iranzo és munkatársai által vizsgált két Cys-t tartalmazó tetrapeptid $\mathrm{Hg}^{2+}$-affinitásához $(\mathrm{pH}=2,0, \lg K=26,2)$ [130], amely a fémion és a peptid közötti rendkívül erős kölcsönhatást mutatja, és magyarázza, hogy miért vannak a $\mathrm{Hg}^{2+}$-ionok már $\mathrm{pH}=2,0$ alatt is $100 \%$-ban kötött formában. A PS ligandum és a $\mathrm{I}^{-}$-ionok kompetícióját (azaz a ténylegesen végbemenő folyamatokat) jól szemlélteti a stabilitási állandók felhasználásával kiszámolható eloszlási diagram (5.3.1.13. ábra).

$$
\begin{gathered}
\mathrm{Hg} \mathbf{L}^{\prime}+3 \mathrm{I}^{-} \rightleftharpoons\left[\mathrm{HgI}_{3}\right]^{-}+\mathbf{L}^{\prime} \\
\mathrm{HgL}^{\prime}+4 \mathrm{I}^{-} \rightleftharpoons\left[\mathrm{HgI}_{4}\right]^{2-}+\mathbf{L}^{\prime}
\end{gathered}
$$

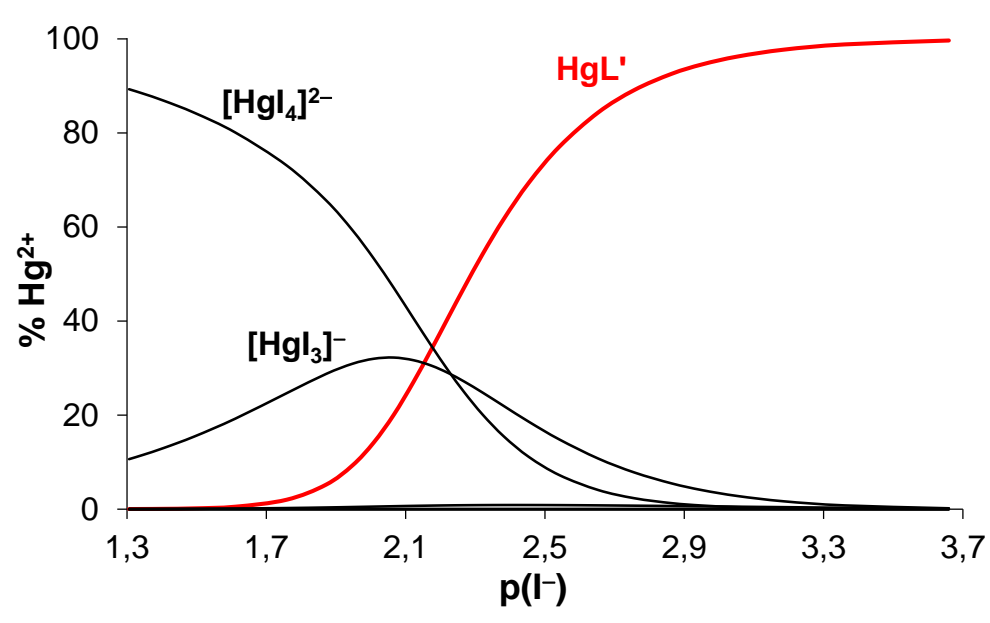

5.3.1.13. ábra: Eloszlásgörbék a $\mathrm{HgCl}_{2}-\mathbf{P S}-\mathrm{I}^{-}$rendszerben $\left(c_{\mathrm{HgCl}_{2}}=5,1 \times 10^{-5} \mathrm{M}, I=0,1 \mathrm{M} \mathrm{NaClO}_{4}, \mathrm{pH}=2,0, T=298 \mathrm{~K}\right)$ 


\subsubsection{A HS ligandum $\mathrm{Hg}^{2+}$-komplexeinek vizsgálata}

A HS peptid $\lambda=230 \mathrm{~nm}$-nél ábrázolt $\mathrm{A}$ vs. $\mathrm{pH}$ görbéi (5.3.2.1. ábra) nagy hasonlóságot mutatnak a PP peptidnél mért görbékkel (5.3.1.2. ábra). A fémion jelenlétében az M:L aránytól függetlenül $\left\{2 \times \mathrm{S}^{-}\right\}$típusú koordináció valósul meg a vizsgált $\mathrm{pH}$ tartományban. Továbbá ligandumfelesleget alkalmazva a $\mathrm{HgL}$ monokomplex mellett jelen lévő szabad HS pH = 8-10,5 között koordináció nélkül deprotonálódik.

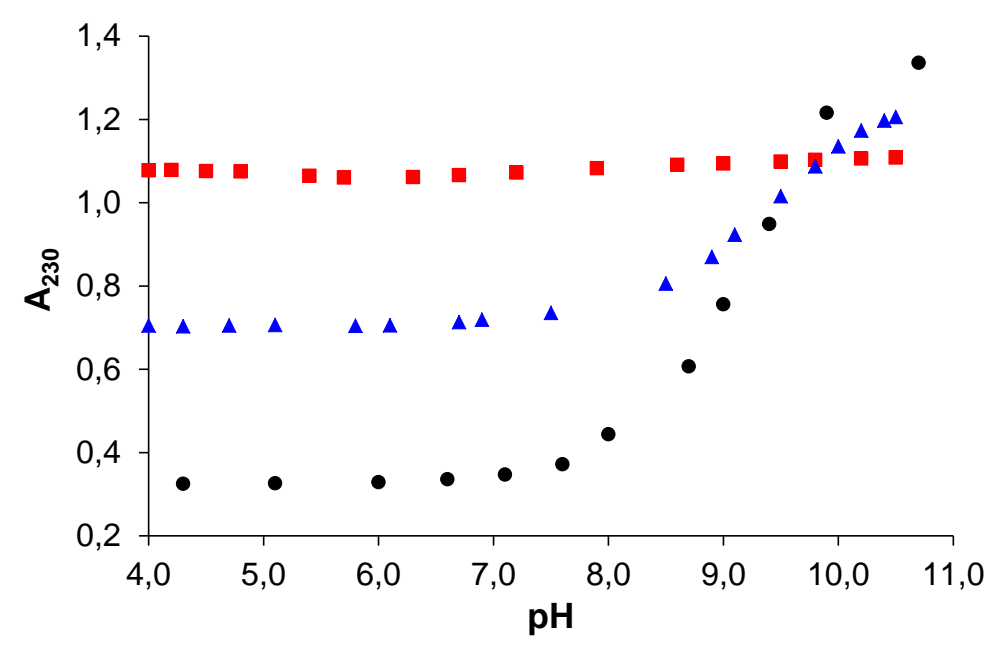

5.3.2.1. ábra: Különböző $\mathrm{Hg}^{2+}-\mathbf{H S}$ fémion:ligandum arányú rendszerek $\mathrm{A} v s$. $\mathrm{pH}$ görbéje összehasonlítva a szabad ligandummal. • : Szabad HS, $\triangle: \mathrm{Hg}^{2+}$-HS 0,5:1, 匹: $\mathrm{Hg}^{2+}-\mathbf{H S ~ 1 : 1}$ $\left(c_{\mathrm{HS}}=1,0 \times 10^{-4} \mathrm{M}, I=0,1 \mathrm{M} \mathrm{NaClO}_{4}, l=10 \mathrm{~mm}, T=298 \mathrm{~K}\right)$

A $\mathrm{Hg}^{2+}$-HS rendszerben ugyancsak részletes ${ }^{1} \mathrm{H}-\mathrm{NMR}$ mérések révén próbáltuk követni a lejátszódó folyamatokat (5.3.2.2. ábra). Egy ekvivalens fémion jelenlétében a Cys egységek $\mathrm{C}_{\beta} \mathrm{H}_{2}$ jelei meglehetősen kiszélesednek és eltolódnak az alacsonyabb terek irányába ( $\delta \sim 3,3-3,4$ ppm). A szignifikáns, $\sim 0,4$ ppm eltérés a szabad $\mathbf{H S}$ Cys $\mathrm{C}_{\beta} \mathrm{H}_{2}$ jeleihez képest az UV mérésekkel összhangban, a ligandum tiolátcsoportjainak kötődését mutatja.

Ligandumfelesleg mellett felvett spektrumokon a savas $\mathrm{pH}$ tartományban két, egymástól szeparált $\mathrm{Cys} \mathrm{C}_{\beta} \mathrm{H}_{2}$ jelcsoportot azonosítottunk. Ezek közül az egyik $(\delta \sim 2,9$ ppm) nagy hasonlóságot mutat a szabad ligandum $\mathrm{Cys}_{\beta} \mathrm{H}_{2}$ rezonanciával, míg a $\delta \sim 3,3-3,4$ ppm-nél lévő jelek az 1:1 fémion: ligandum arányú rendszerben tapasztalt $\mathrm{Cys}_{\mathrm{S}} \mathrm{C}_{\beta} \mathrm{H}_{2}$ jelekhez hasonlítanak. A pH növelése $(\mathrm{pH}=8,0)$ az említett két szeparált jelcsoport (a PP peptidhez hasonlóan (5.3.1. fejezet)) összeolvadását eredményezi. A széles jel a $\delta \sim 2,8-3,4$ ppm tartományba esik, azonosítását megnehezíti, hogy a His $\mathrm{C}_{\beta} \mathrm{H}_{2}$ jelekkel azonos kémiai eltolódás tartományba esik (5.3.2.2. ábra, nagyítás). Ez a kiszélesedett jel valamivel élesebb lesz $\mathrm{pH}=10,0$-ra, azonban továbbra is átfed a His $\mathrm{C}_{\beta} \mathrm{H}_{2}$ rezonanciákkal. 
Ennek magyarázatául szolgálhat, hogy a ligandumcsere sebessége a szabad és a kötött forma között a lassú/közepes felöl a közepes/gyors felé változik, párhuzamosan a nem koordinálódó ligandum tiolcsoportjainak deprotonálódásával.
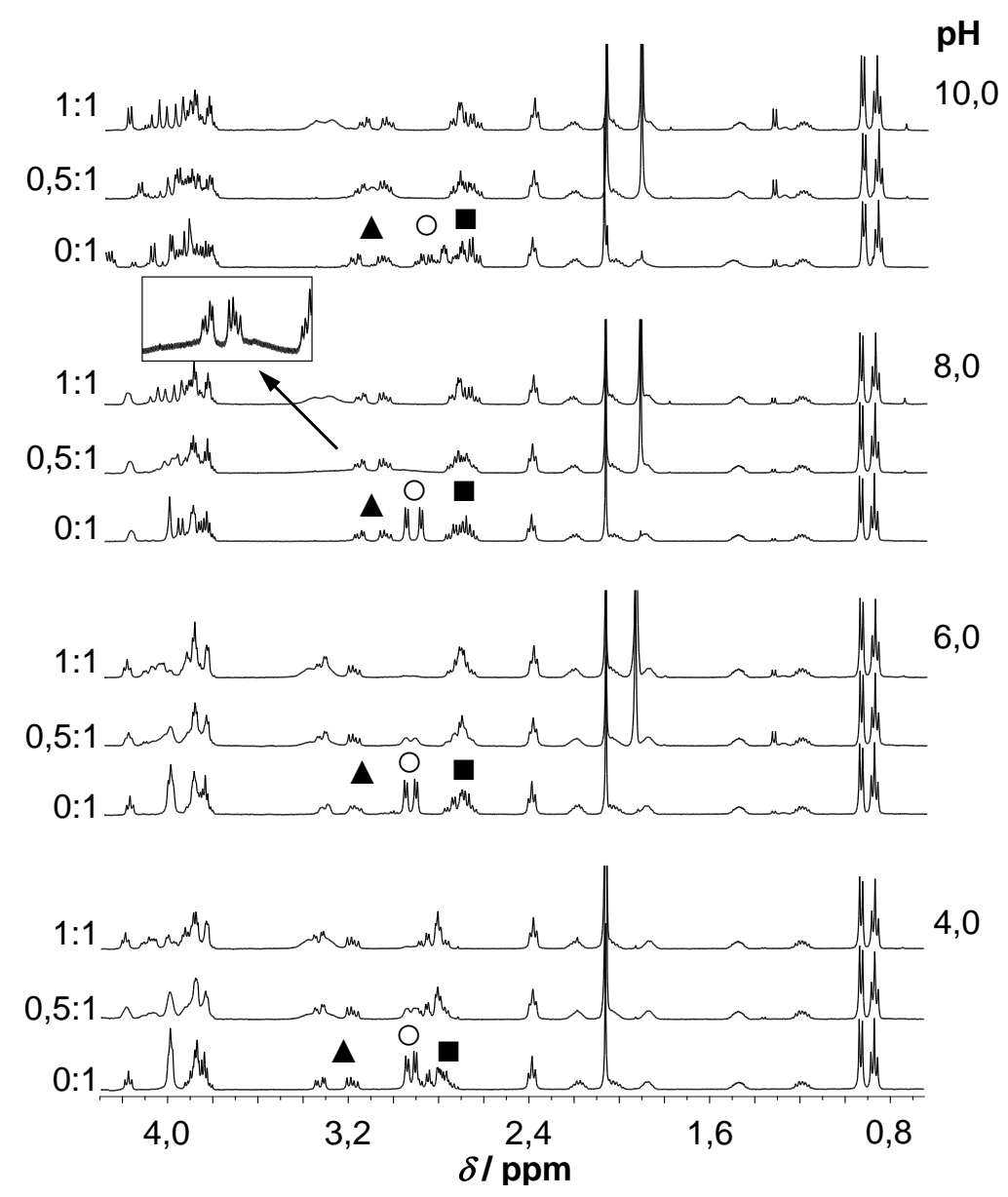

5.3.2.2. ábra: $\mathrm{A} \mathrm{Hg}^{2+}-\mathrm{HS}$ rendszerben felvett ${ }^{1} \mathrm{H}$ NMR spektrumok részlete az alifás hidrogének

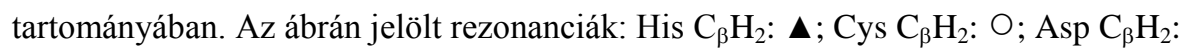
$\left(c_{\mathrm{HS}}=1,3 \times 10^{-3} \mathrm{M}, \mathrm{H}_{2} \mathrm{O} / \mathrm{D}_{2} \mathrm{O}=90 / 10 \% \mathrm{v} / \mathrm{v}, I=0,1 \mathrm{M} \mathrm{NaClO}_{4}, T=298 \mathrm{~K}\right)$

Az általunk tapasztalt vonalszélesedésből lehetőség van megbecsülni a szabad és kötött ligandum közötti cseresebességet $\left(k_{\mathrm{ex}}\right) \mathrm{pH}=4,0-6,0$ tartományban, ahol lassú cseresebesség dominál [131]. A szabad ligandum $\mathrm{Cys} \mathrm{C}_{\beta} \mathrm{H}_{2}$ jelein 0,5 ekvivalens $\mathrm{Hg}^{2+}$-ion hozzáadását követően $\sim 12 \mathrm{~Hz}$ szélesedést tapasztaltunk $\left(w_{\mathrm{e}}-w_{0}\right.$, ahol a $w_{\mathrm{e}}$ és a $w_{0}$ a cserével és csere nélkül tapasztalt félértékszélességet jelöli). Ez alapján $\mathrm{pH}=6,0$-nál a $k_{\mathrm{ex}} \sim \pi \sim\left(w_{\mathrm{e}^{-}}\right.$ $\left.w_{0}\right) \sim 38 \mathrm{~s}^{-1}$. A számítások alapját az a feltételezés adhatja, hogy az említett kísérleti körülmények között a HS peptid egy specifikus $\mathrm{Hg}^{2+}$-peptid komplex és szabad forma között cserélődik. A $k_{\mathrm{ex}}$ megadható a következő egyenlet szerint [132]:

$$
k_{\text {ex }}=k_{\text {on }}[\mathrm{M}]+k_{\text {off }}=\frac{k_{\text {off }}}{1-f}
$$


ahol $k_{\text {on }}$ és $k_{\text {off }}$ másodrendü sebességi együtthatók a komplex képződésére és elsőrendü együtthatók a komplex disszociációjára, $[\mathrm{M}]$ a fémion koncentrációja, $f$ pedig a kötésben lévő ligandumok mennyiségét mutatja (jelen esetben 0,5).

Ha abból indulunk ki, hogy az asszociáció (vagyis az ML komplex képződése) diffúziókontrollált, $298 \mathrm{~K}$-en vizes közegben a $k_{\mathrm{on}} \sim 7,4 \times 10^{9} \mathrm{M}^{-1} \mathrm{~s}^{-1}$ [133]. Az előzőekben említett egyenletet $[\mathrm{M}]=\left[\mathrm{Hg}^{2+}\right]$-re megoldva $\mathrm{pH}=6,0$-nál számolt disszociációs egyensúlyi állandó értéke $K_{\mathrm{d}}=2,5 \times 10^{-9} \mathrm{M}$, amely több nagyságrenddel kisebb a $\left\{2 \times \mathrm{S}^{-}\right\}$típusú $\mathrm{Hg}^{2+}-$ komplex egyensúlyi állandóitól [134], mely azt sugallja, hogy a kezdeti feltételezésünknél jóval összetettebb rendszerről van szó.

A tiszta $\mathrm{D}_{2} \mathrm{O}$-ban felvett spektrumok szintén azt mutatják (5.3.2.3. ábra), hogy a His imidazolgyürü $\mathrm{C}_{\varepsilon 1} \mathrm{H}$ és $\mathrm{C}_{\delta 2} \mathrm{H}$ jelei $\mathrm{pH}$-tól és a fémion: ligandum aránytól függetlenül is nagy hasonlóságot mutatnak mind az 1:1 mind a szabad ligandum tartalmú rendszerrel

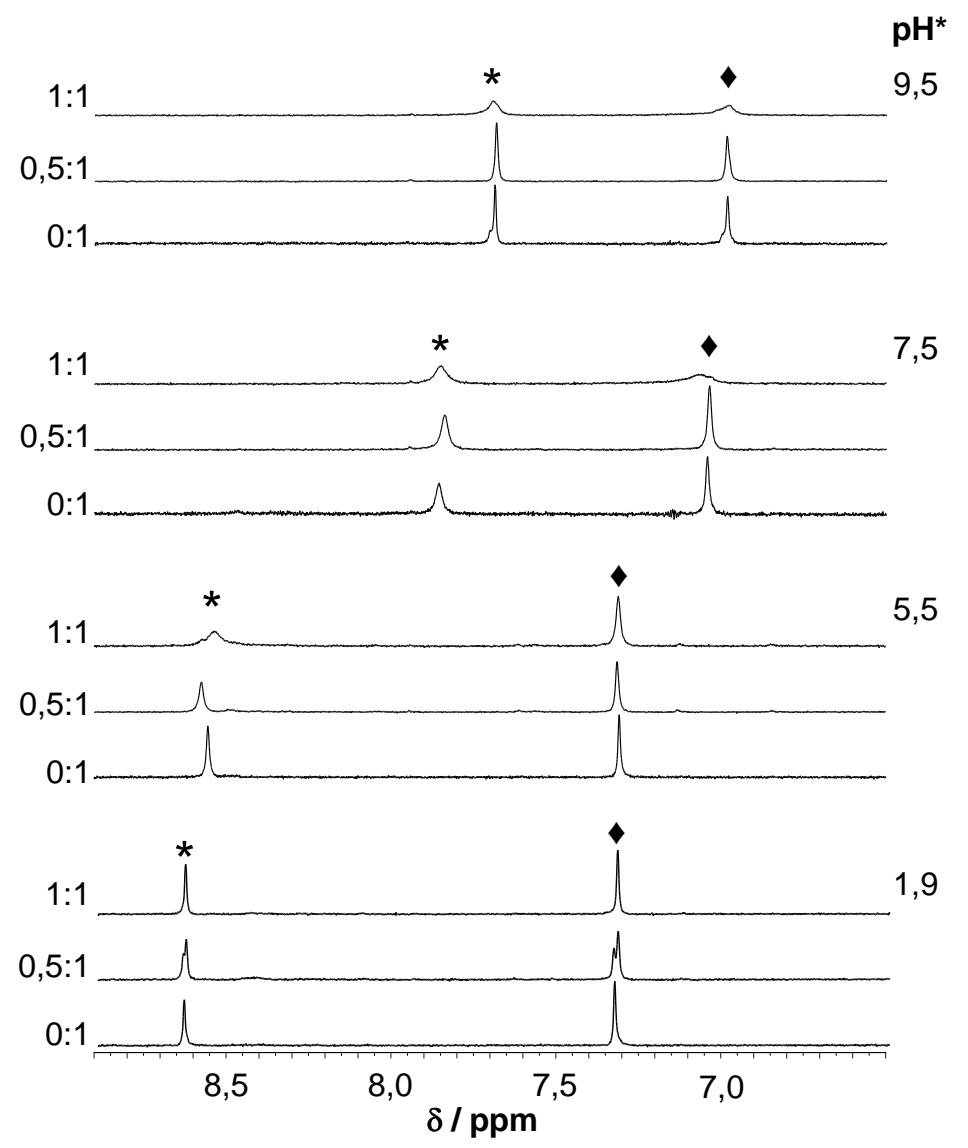

5.3.2.3. ábra: $\mathrm{A} \mathrm{Hg}^{2+}-\mathrm{HS}$ rendszerben felvett ${ }^{1} \mathrm{H}$ NMR spektrumok részlete az aromás hidrogének tartományában. Az ábrán jelölt rezonanciák: His $\mathrm{C}_{\varepsilon 1} \mathrm{H}(*)$ és $\mathrm{C}_{\delta 2} \mathrm{H}(\bullet)$

$\left(c_{\text {HS }}=1,0 \times 10^{-3} \mathrm{M}, 100 \% \mathrm{D}_{2} \mathrm{O}, I=0,1 \mathrm{M} \mathrm{NaClO}_{4}, T=298 \mathrm{~K}\right)$

A HS peptid $\mathrm{Hg}^{2+}$-komplexeinek PAC spektrumai (5.3.2.3. ábra), illetve az ezekből számolható paraméterek (5.3.1.1 táblázat) is hasonlóak His-t nem tartalmazó 1:1 arányú komplexekéhez (5.3.1.8. ábra). 

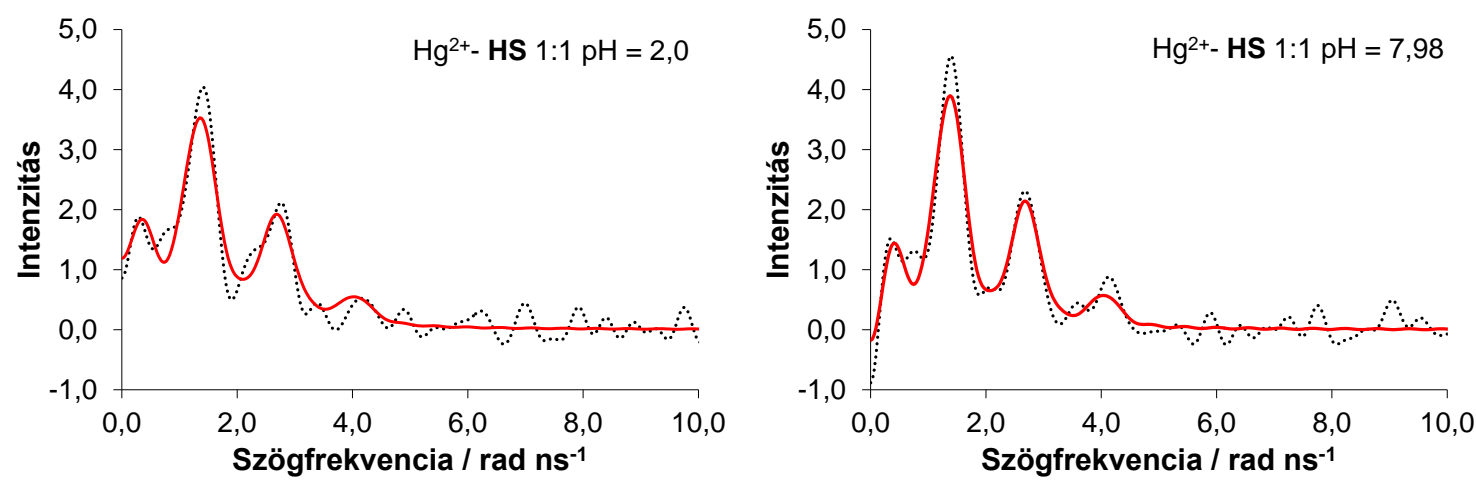

5.3.2.4. ábra: $\mathrm{A} \mathrm{Hg}^{2+}$-HS $1: 1$ fémion:ligandum arányú rendszereinek különböző $\mathrm{pH}-n$ mért $\mathrm{PAC}$ spektruma A kísérleti adatok Fourier-transzformáltjai (fekete szaggatott görbe), illetve azok illesztése (piros görbe)

Azonban a $\mathrm{Hg}^{2+}$-ionok feleslege mellett a $\mathbf{H S}$ peptidnél is tapasztaltuk többmagvú komplexek képződését. A peptidhez viszonyítva ekvivalens $\mathrm{Hg}^{2+}$-iont tartalmazó rendszerhez képest a spektrum alakja savas pH-n megváltozik (5.3.2.4. ábra). Az illesztés csak két részecske feltételezésével volt elfogadható. Az illesztéssel nyert paraméterek alapján az egyik komponens azonos lehet az 1:1 fémion:ligandum arányú rendszerben képződő komplexszel. Az 5.3.1.2. táblázatban bemutatott $v_{\mathrm{Q}}$ frekvencia és $\eta$ szimmetriaparaméterek alapján a második komponensben egy olyan szerkezet, illetve $\mathrm{Hg}^{2+}$ környezet feltételezhető, amelyben a peptid két tiolátcsoportja hídligandumként, két hidat kialakítva köti össze a két $\mathrm{Hg}^{2+}$-centrumot.

Lúgos körülmények között egy uralkodó részecske feltételezésével leírható a rendszer. Azonban, ahogy azt már korábban a $\mathrm{Hg}^{2+}$-PS komplexeknél láttuk, a paraméterek eltérőek az 1:1 fémion ligandum aránytól (5.3.1.2. táblázat). Nagy valószínűséggel lúgos pH-n ( $\mathrm{pH}>9)$ a PS peptidnél javasolt szerkezet jelenik meg a $\mathrm{Hg}^{2+}-\mathbf{H S}$ 2:1 arányú rendszer esetén is.
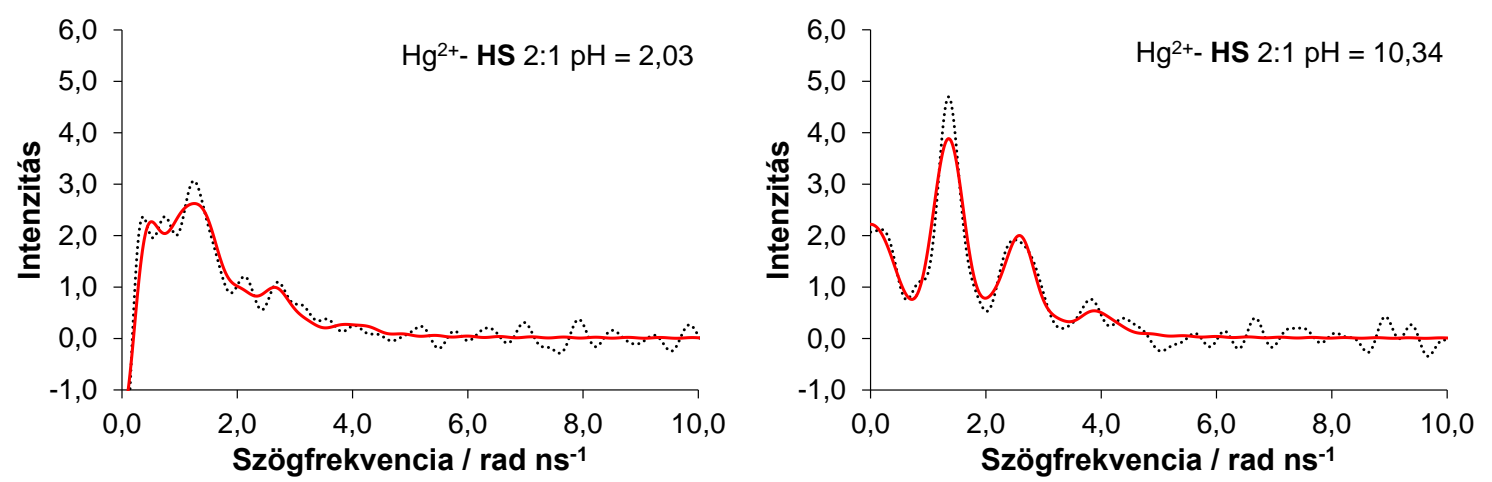

5.3.2.4. ábra: $\mathrm{A} \mathrm{Hg}^{2+}$-HS $2: 1$ fémion:ligandum arányú rendszereinek különböző $\mathrm{pH}-\mathrm{n}$ mért $\mathrm{PAC}$ spektruma A kísérleti adatok Fourier-transzformáltjai (fekete szaggatott görbe), illetve azok illesztése (piros görbe) 
Spektroszkópiai eredményeink alapján kijelenthető, hogy ligandumfelesleg mellett, valamint egy ekvivalens $\mathrm{Hg}^{2+}$-ion jelenlétében a PP peptidhez hasonlóan a $\mathbf{H S}$ peptidben sem az Asp karboxilát-, sem a His imidazolcsoportok nem vesznek részt a koordinációban. Továbbá a fémion feleslegének jelenlétében többmagvú komplexek képződése is lehetséges, melyek hasonlóan az előző fejezetben leírtakhoz a pH-tól függően különböző szerkezetủek lehetnek.

\subsection{A vizsgált ligandumok $\mathrm{Ag}^{+}$-ionokkal alkotott komplexei}

O’Halloran és munkatársai [2] korábban már bizonyították, hogy a CueR fehérje kétértékü fémionok jelenlétében nem mutat pozitív biológiai választ. Ezért különösen érdekes, hogy modellpeptidek szintjén is összevessük kétértékü fémionokkal alkotott komplexeinket egyértékű, szoft karakterü $\mathrm{Ag}^{+}$-ionok komplexeivel. Méréseinket a PP és EC peptidekkel is elvégeztük, azonban bemutatni csak az $\mathrm{Ag}^{+}$-PP vizsgálatokat fogom, mivel az EC peptidet alkalmazva nagyon hasonló eredményeket kaptunk.

\subsubsection{UV spektroszkópiai vizsgálatok az $\mathrm{Ag}^{+}-\mathrm{PP}$ rendszerben}

A $\lambda=230 \mathrm{~nm}$-nél mért A vs. $\mathrm{pH}$ pontsorokon egy ekvivalens $\mathrm{Ag}^{+}$-ion jelenlétében szembetünő, hogy már $\mathrm{pH}=3$-nál jelentős abszorbancia növekedés van a fémiont nem tartalmazó peptidmintához képest (5.4.1.1. ábra). Az abszorbancia-növekedés ebben a $\mathrm{pH}$ tartományban nagyon hasonló a $\mathrm{Hg}^{2+}$-PP komplexnél tapasztaltakhoz, ahol bizonyítottuk, hogy már savas $\mathrm{pH}-\mathrm{n}$ is a $\left\{2 \times \mathrm{S}^{-}\right\}$típusú koordináció a meghatározó (5.3.1.2. ábra). Ez alapján azt feltételezhetnénk, hogy a PP ligandum mind a két Cys tiolcsoportjával kötődik az $\mathrm{Ag}^{+}$-ionhoz.

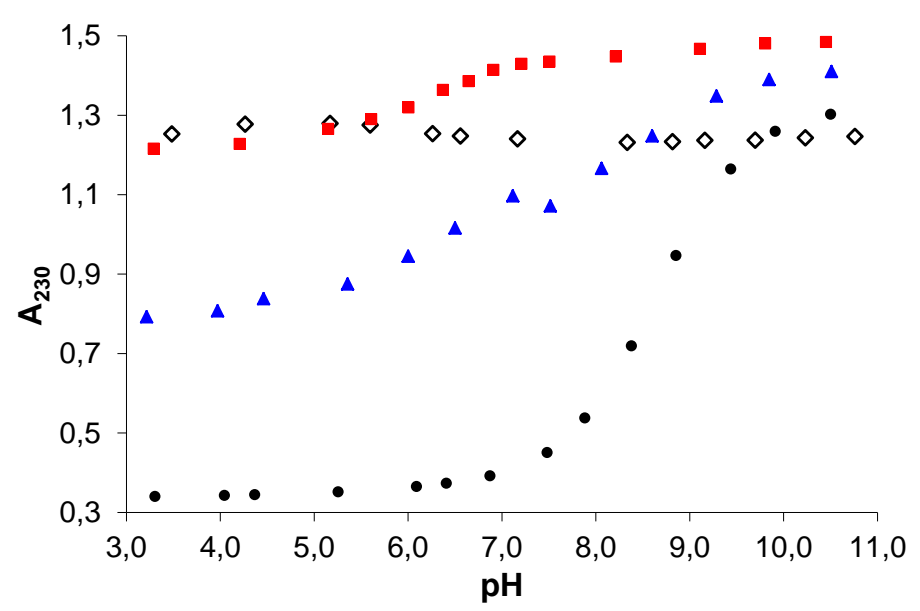

5.4.1.1. ábra: Különbözö $\mathrm{Ag}^{+}-\mathbf{P P}$ fémion:ligandum $\mathrm{A}$ vs. $\mathrm{pH}$ görbéinek összehasonlítása a $\mathrm{Hg}^{2+}-\mathbf{P P}$

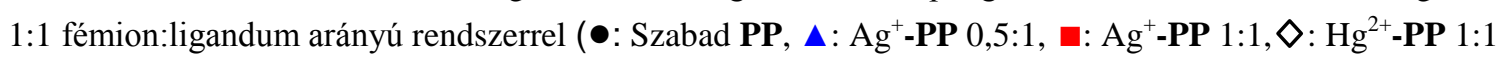
$\left(c_{\mathbf{P P}}=1,0 \times 10^{-4} \mathrm{M}, I=0,1 \mathrm{M} \mathrm{NaClO}_{4}, l=10 \mathrm{~mm}, T=298 \mathrm{~K}\right)$ 
A pH 5,5-7 tartományban azonban abszorbancia-növekedés figyelhető meg az $\mathrm{Ag}^{+}-$ PP 1:1 fémion:ligandum arányú rendszerben. A változás egy koordinált tiolcsoport deprotonálódásához, vagy a ligandum egy másik koordinálódó donorcsoportjának tiolátcsoportra való cseréjéhez rendelhető.

A kétszeres ligandumfelesleget tartalmazó rendszer UV-titrálási görbéjén $\mathrm{pH}=6$ felett az abszorbancia értékek szélesebb pH tartományban emelkednek, ami egymással átfedő folyamatok eredményeként értelmezhető. Másrészt amennyiben különböző összetételü és eltérő koordinációs módú (mono- és bisz) komplexek vannak jelen az oldatban úgy a ligandum bizonyos hányada és/vagy tiolcsoportjaik egy része protonált formában van, így ezek a szabad ligandumra jellemző pH-tartományban deprotonálódnak.

A komplexek kialakulását megfigyelhetjük úgy is, hogy egy adott pH-n lépésenként

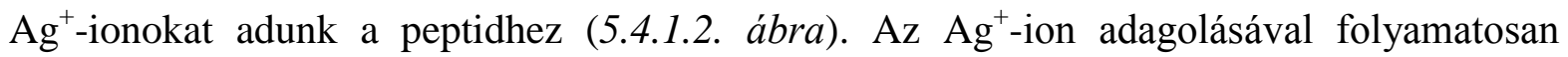
növekszik az elnyelés azonban a rendszer összetettségét mutatja, hogy az abszorbancia csak 50\%-os $\mathrm{Ag}^{+}$-ion felesleg után áll be egy állandó értékre. Ez utalhat arra, hogy a rendszerben többmagvú vagy klaszter jellegü részecskék is képződnek.

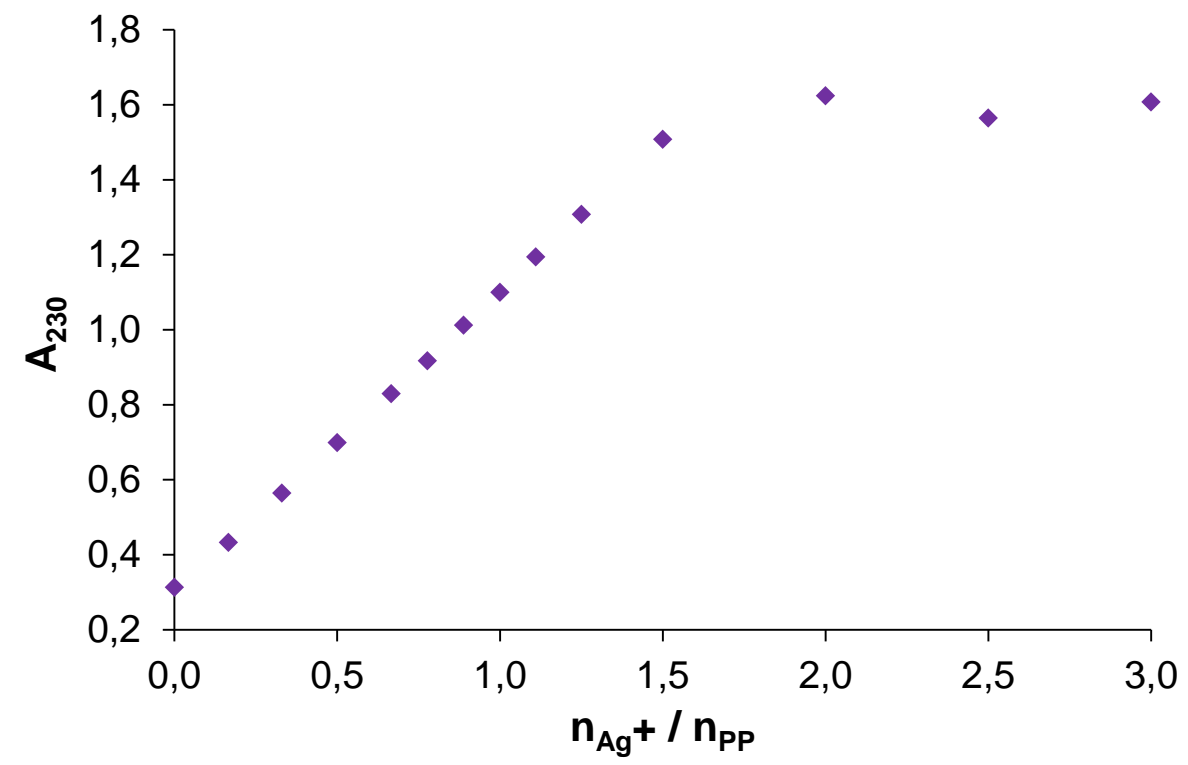

5.4.1.2. ábra: $\mathrm{Az} \mathrm{Ag}^{+}-\mathbf{P P}$ rendszerben a fémion mennyiségének növelése mellett mért abszorbancia-változás $\left(c_{\mathbf{P P}}=1,0 \times 10^{-4} \mathrm{M}, I=0,1 \mathrm{M} \mathrm{NaClO}_{4}, \mathrm{pH}=2,0, l=10 \mathrm{~mm}, T=298 \mathrm{~K}\right)$

\subsubsection{Egyensúlyi vizsgálatok $a_{z} \mathrm{Ag}^{+}-\mathrm{PP}$ rendszerben}

$\mathrm{Az} \mathrm{Ag}^{+}$-ionokat tartalmazó rendszerekben 1:1 fémion:ligandum arány mellett végeztünk $\mathrm{pH}$-potenciometriás vizsgálatokat (5.4.2.1. ábra). Megfigyelhető, hogy már $\mathrm{pH}=$ 3,0 alatt is eltérés van az ekvivalens $\mathrm{Ag}^{+}$-iont tartalmazó rendszer és a szabad ligandum görbéje között. Ez összhangban az UV eredményekkel tükrözi, hogy a komplexképződés már savas $\mathrm{pH}$ tartományban is számottevő mértékü. 
A rendszer összetettségét jelzi, hogy $\mathrm{Ag}^{+}$-ionok jelenlétében az inflexióspontok nem egész ekvivalens lúgfogyás értékeknél találhatók. Az adatsorok kvantitatív kiértékelését azonban nem tudtuk megoldani, ugyanis fémionok jelenlétében a titrálások kezdetén tapasztalt extra lúgfogyás a fémionok teljes mennyiségének kötöttségére utal.

Az ekvimoláris mintában $\mathrm{pH}=5,5$-ig történő 3 ekvivalens lúgfogyás arra utal, hogy ezen pH-ig a két karboxilcsoport mellett az egyik Cys tiolcsoport deprotonálódása is lejátszódik. Mivel ez a folyamat a szabad ligandum tiolcsoportjait jellemző $\mathrm{p} K_{\mathrm{s}}$ értékeknél jóval alacsonyabb pH-n játszódik le (5.1.2.1. táblázat), így az Ag-S kötés kialakulása bizonyított.

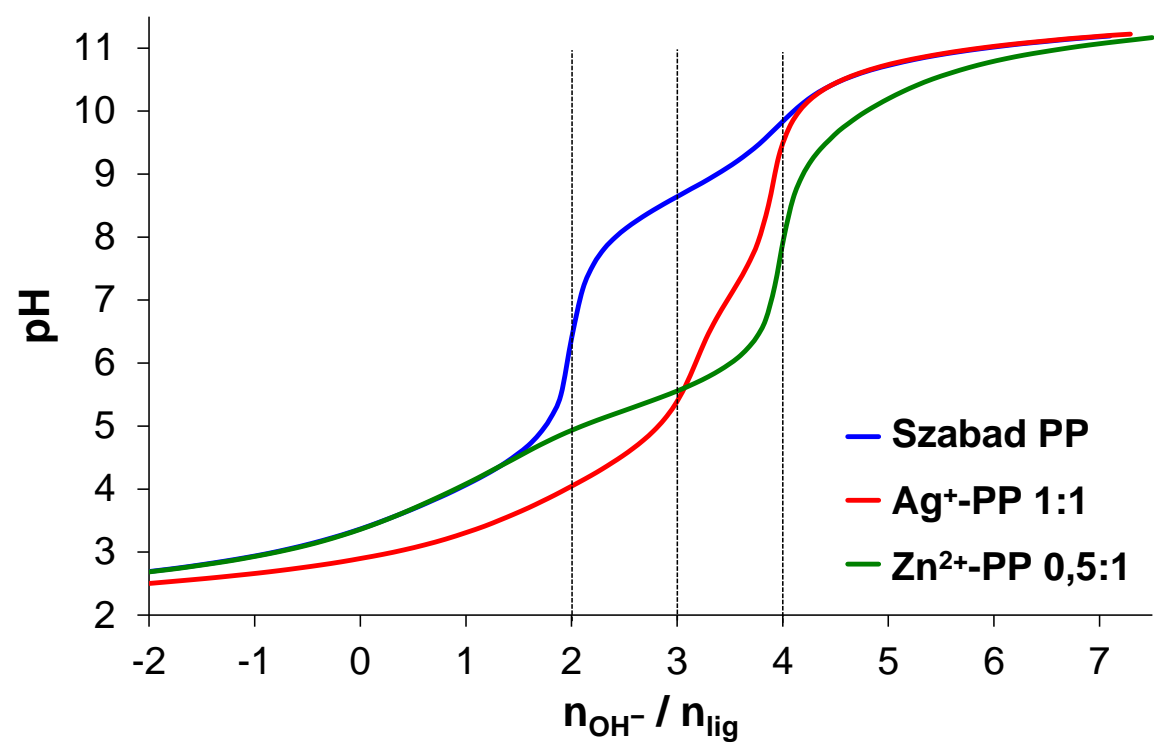

5.4.2.1. ábra: $\mathrm{Az} \mathrm{Ag}^{+}-\mathbf{P P}$ különböző fémion:ligandum arányú rendszerek normált titrálási görbéi $\left(c_{\mathbf{P P}}=1,0 \times 10^{-3} \mathrm{M}, I=0,1 \mathrm{M} \mathrm{NaClO}_{4}, T=298 \mathrm{~K}\right)$

A pH 5,5-7 tartományban egy újabb lépcső látható a titrálási görbén, mely az UV titrálásoknál megfigyelt változáshoz hasonlóan $\mathrm{p} K_{\mathrm{s}} \sim 6,5$ értékkel jellemezhető. Ez az érték körülbelül egy $\mathrm{pH}$ egységgel alacsonyabb, mint a szabad ligandum cisztein oldalláncainak $\mathrm{p} K_{\mathrm{s}}$ értékei (5.1.2.1. táblázat). A folyamatot jellemző $\mathrm{p} K_{\mathrm{s}}$ érték az általunk vizsgált fémionok között egyedi az egyértékü fémionra, s így meghatározó lehet a CueR fémion-szabályzó fehérje müködésében.

\subsubsection{CD spektroszkópiai vizsgálatok $a_{z} \mathrm{Ag}^{+}-\mathrm{PP}$ rendszerben}

Az pH-potenciometriás és UV spektroszkópiai mérésekkel jó egyezésben megfigyelhető, hogy savas pH-n a ligandum szignifikáns mennyisége fémionhoz kötött formában van (5.4.3.1. ábra). 


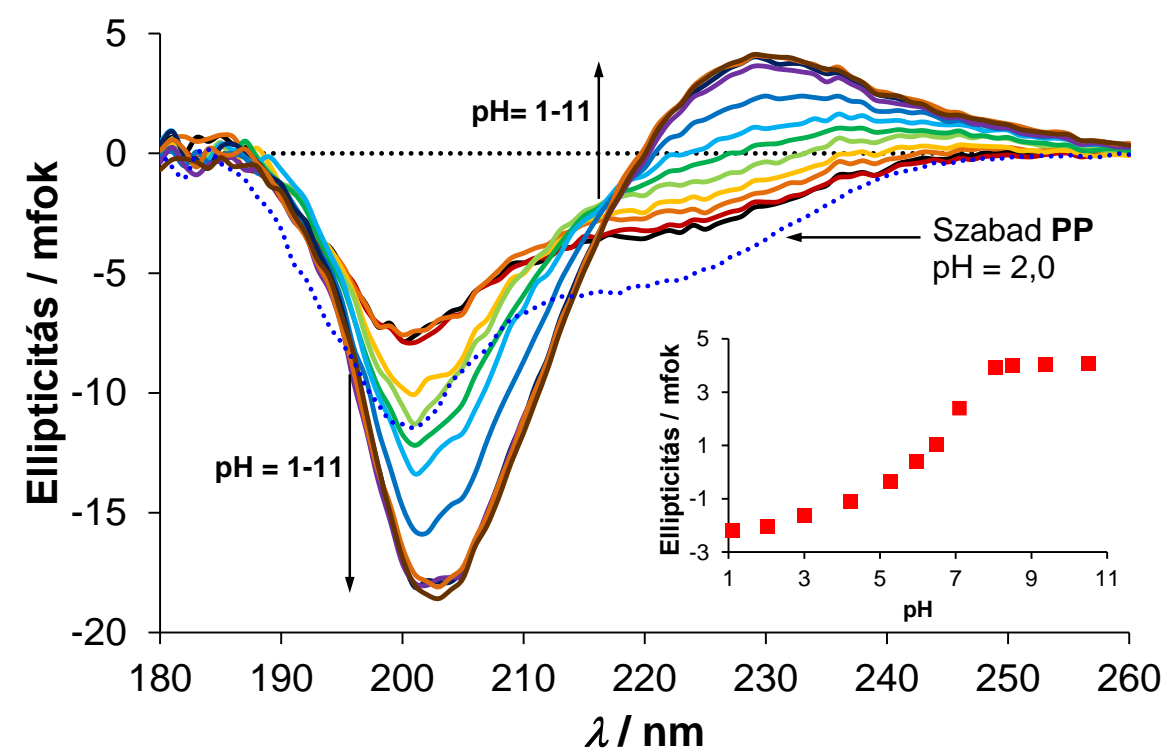

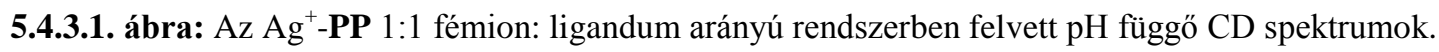
Inzertben az ellipticitás változása a $\mathrm{pH}$-val $\lambda=230 \mathrm{~nm}$-en $\left(c_{\mathbf{P P}}=1,0 \times 10^{-4} \mathrm{M}, I=0,1 \mathrm{M} \mathrm{NaClO}_{4}, l=1 \mathrm{~mm}, T=298 \mathrm{~K}\right)$

Ezt a szabad PP pH = 2,0-nál mért CD spektrumától való eltérés is mutatja. $\mathrm{pH}=2,0$ 5,3 között enyhe intenzitás-növekedés látható a $\lambda=215-250 \mathrm{~nm}$ hullámhossz-tartományban, mely a szabad ligandum titrálásával megegyezően az aszparaginsavak deprotonálódását kísérő konformáció-változáshoz rendelhető. A pH 6-8 közötti ellipticitás-növekedés jelentős konformáció-változáshoz rendelhető, továbbá pH 6-8 között a spektrumok sorozatán $\lambda=218$ nm-nél egy izodikroikus pont figyelhető meg, amely két egymással egyensúlyban lévő részecske jelenlétére utal.

\subsubsection{NMR spektroszkópiai vizsgálatok $a z \mathrm{Ag}^{+}-\mathrm{PP}$ rendszerben}

Egy ekvivalens $\mathrm{Ag}^{+}$-ion jelenlétében már $\mathrm{pH}=2,0$-n mért spektrumon látható a jelek kiszélesedése (5.4.4.1. ábra), mely a fémionnal való kölcsönhatás eredménye. Hasonlóan a $\mathrm{Hg}^{2+}$-PP rendszerhez, egy új, széles jel kifejlődését tapasztaltuk $\delta=3,0-3,3 \mathrm{ppm}$ tartományban, a szabad ligandum $\mathrm{Cys} \mathrm{C}_{\beta} \mathrm{H}_{2}$ jeleihez képest magasabb ppm értékeknél. Ez alapján feltételezhetjük, hogy a ciszteinek tiolcsoportjainak egy része koordinálódik a fémionhoz. Továbbá mivel az Asp $\mathrm{C}_{\beta} \mathrm{H}_{2}$ rezonanciák a vizsgált $\mathrm{pH}$ tartományban nagyon hasonlóak a szabad ligandum Asp $\mathrm{C}_{\beta} \mathrm{H}_{2}$ jeleihez ( $F 9$ ábra), kijelenthetjük, hogy - a $\mathrm{Hg}^{2+}$ komplexekhez hasonlóan - a karboxilcsoportok nem vesznek részt a koordinációban. Érdekes eredményeket kaptunk a pH növelésével, ugyanis az Asp egységek deprotonálódását követően egy a szabad ligandum Cys $\mathrm{C}_{\beta} \mathrm{H}_{2}$ rezonanciájához nagyon hasonló jelet láthatunk $\delta=2,80-3,01$ ppm tartományban (5.4.4.1. ábra inzert). 


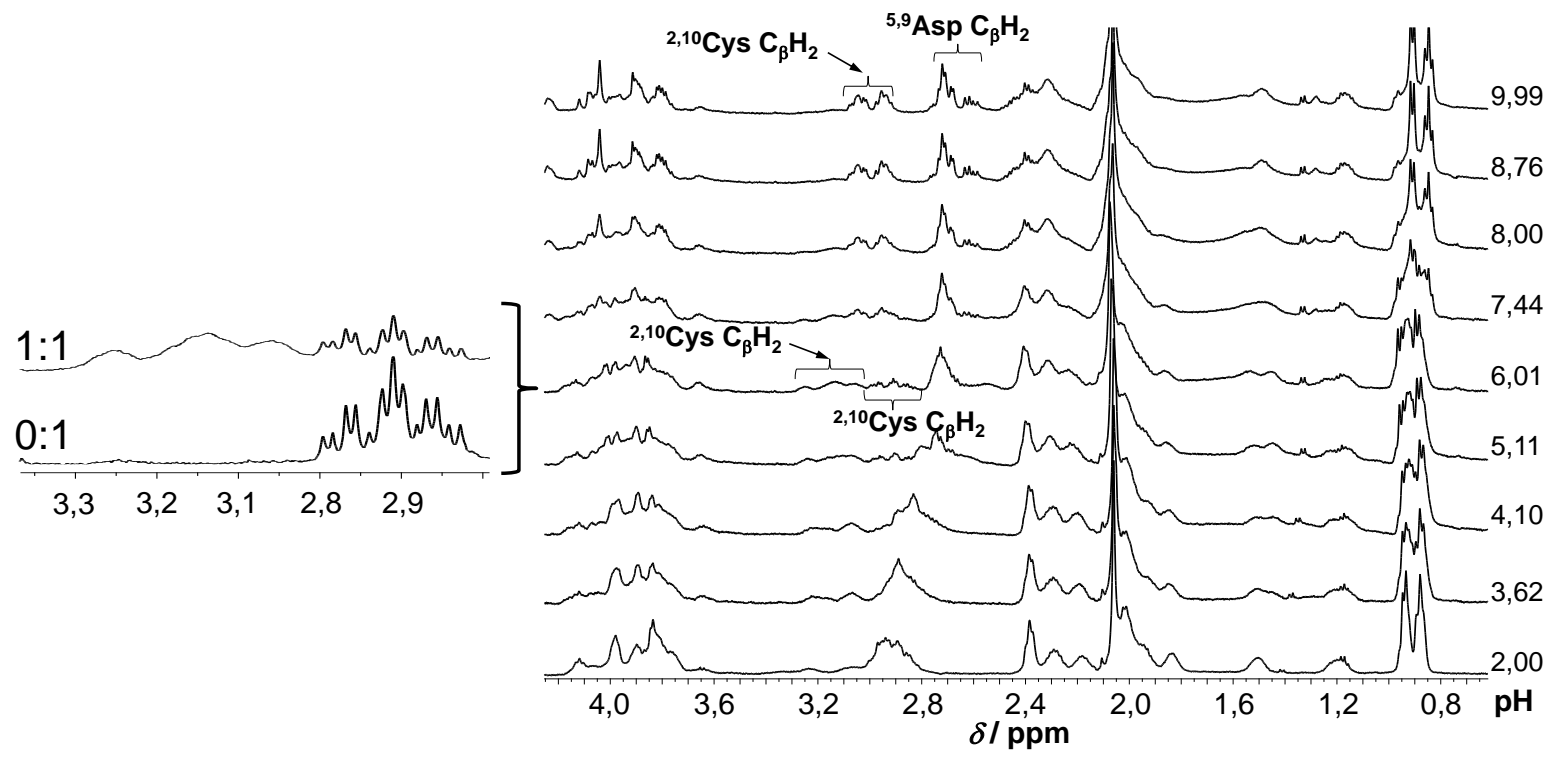

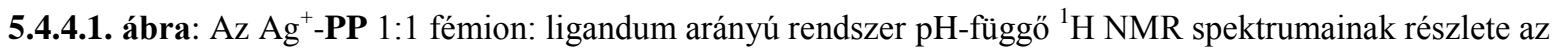
alifás hidrogének tartományában. Inzertben a $\mathrm{pH}=6,0$-nál mért $\mathrm{Cys}_{\beta} \mathrm{C}_{2}$ jelek összehasonlítása fémion jelen és távollétében $\left(c_{\mathbf{P P}}=1,3 \times 10^{-3} \mathrm{M}, \mathrm{H}_{2} \mathrm{O} / \mathrm{D}_{2} \mathrm{O}=90 / 10 \% \mathrm{v} / \mathrm{v}, I=0,1 \mathrm{M} \mathrm{NaClO}_{4}, T=298 \mathrm{~K}\right)$

Ez alapján feltételezhetjük, hogy a tiolcsoportok egy része még protonált formában van $\mathrm{pH}=6,0$-nál. Továbbá érdemes szemügyre venni a $\delta=0,8-1,6 \mathrm{ppm}$ tartományban az Ile egység rezonanciáit, ugyanis kivétel nélkül megkettőződtek. $\mathrm{Ag}^{+}$-ionok jelenlétében az Ile $\mathrm{C}_{\gamma 1} \mathrm{H}_{2}$ rezonanciákból láthatunk egy $\delta=1,53$ ppm értékkel valamint egy - a magasabb terek irányába tolódott $-\delta=1,45$ ppm értékkel jellemezhető multiplettet. Ennek magyarázata az lehet, hogy $\mathrm{pH}=6,0$-nál a két tiolcsoport eltérő protonálódási állapota miatt kötési izomereket látunk, és közöttük a cseresebesség lassú.

Ezt követően a $\mathrm{pH}=6,01$-nél elvégeztem Cys aminosavak $\mathrm{C}_{\beta} \mathrm{H}_{2}$ jeleinek integrálását, referenciaként a $\delta=2,65-2,79$ ppm tartományban lévő két Asp összesen négy protonjához tartozó $\mathrm{C}_{\beta} \mathrm{H}_{2}$ jeleket használtam. $\mathrm{Az} \mathrm{Ag}^{+}$-ionhoz kötött $\mathrm{Cys} \mathrm{C}_{\beta} \mathrm{H}_{2}$ jeleiböl (3,01-3,29 ppm) valamivel több, mint két proton, míg a szabad ligandum protonált tiolcsoportjával szomszédos $\mathrm{C}_{\beta} \mathrm{H}_{2}$ rezonanciáihoz hasonló jelcsoportból (2,80-3,01 ppm) pedig valamivel kevesebb, mint két proton számolható. Az eredmény azt mutatja, hogy ezen a pH-n a Cys egységek nagyobb részt tiolátként kötődnek a fémionhoz, míg egyre kevesebb a protonált tiolcsoportok aránya. Ez jó egyezést mutat az eddigi módszerekkel becsült $\mathrm{p} K_{s} \sim 6,5$ értékkel, miszerint $\mathrm{pH}=6$ felett a ligandum második tiolcsoportjának deprotonálódása történik. A pH növelésével a Cys $\mathrm{C}_{\beta} \mathrm{H}_{2}$ kötött és szabad-szerű rezonanciái egyre közelebb kerülnek egymáshoz, míg pH = 8,8-nál koaleszcencia történik, vagyis ezek a jelek összeolvadnak (5.4.4.1. ábra). 
Ebből arra következtethetünk, hogy a pH = 6-nál megfigyelt kötési izomerek közötti lassú csere a második tiolcsoport deprotonálódásával párhuzamosan felgyorsul. Hasonló

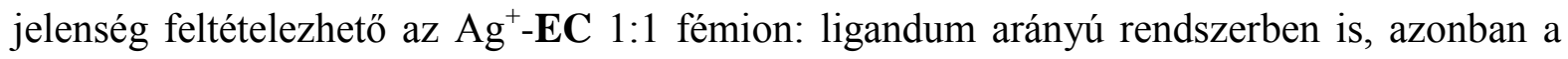
jelek pontos aszignációja a jelentős vonalszélesedés miatt nehéz.

$\mathrm{Az} \mathrm{Ag}^{+}$-ionnal történő vizsgálatok eredményeit összefoglalva elmondható, hogy a pH 6-8,8 között lejátszódó folyamatot jelentős szerkezetváltozás kíséri. Az ${ }^{1} \mathrm{H}$ NMR mérések alapján azt mondhatnánk, hogy savas körülmények között csak egy tiolátcsoport koordinálódik a fémionhoz, majd $\mathrm{pH}$ 6,0-8,8 között a második tiolcsoport deprotonálódásával képződhet a $\left\{2 \times \mathrm{S}^{-}\right\}$típusú komplex. Ebben a $\mathrm{pH}$ tartományban a lúgfogyasztó folyamatot az pH-potenciometriás mérések is alátámasztják, azonban az elektrongerjesztési spektrumok az NMR mérésekhez képest valamelyest eltérő következtetésekhez vezetnek. A pH =3,0-5,5 tartományban a szabad PP-hez képest tapasztalt abszorbancia-növekedés azt sugallja, hogy a ligandum mindkét kéntartalmú donorcsoportja koordinálódik. Elképzelhető lehet tehát egy olyan koordinációs mód, ahol a ligandum Cys aminosavjainak tiolcsoportjai közül az egyik még protonált formában van, és így kötődik a fémionhoz. A protonált tiolcsoport $\mathrm{Ag}^{+}$-koordinálódása ritka, azonban van rá példa [135]. A $\left\{2 \times \mathrm{S}^{-}\right\}$típusú koordináció az UV-, és CD-mérések alapján is csak lúgos körülmények között alakul ki.

Következtetéseink alapján dán együttműködő partnerünk kvantumkémiai számításokat végzett, melyek célja az volt, hogy kiderítsük, milyen hatása lehet a fehérje fémkötő régiójára, ha abban az egyik cisztein tiolcsoportja protonált formában kötődne az $\mathrm{Ag}^{+}$-ionhoz. (5.4.4.3. ábra).
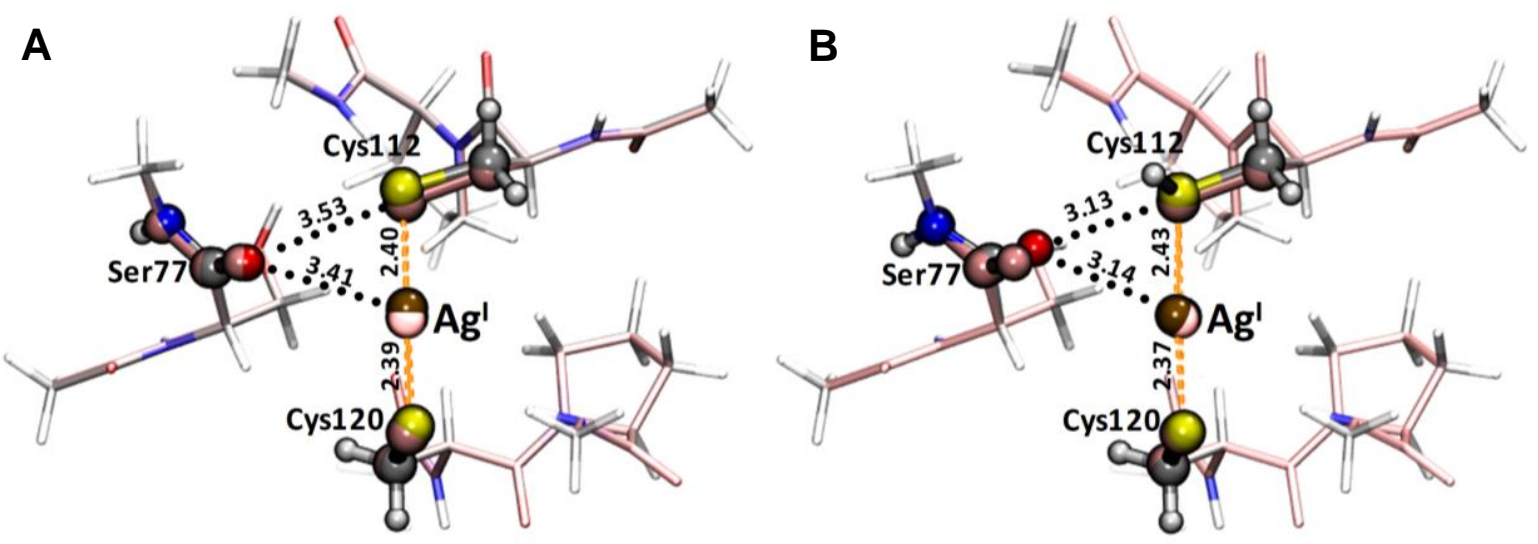

5.4.4.3. ábra: $\mathrm{Az} \mathrm{Ag}^{+}-\mathrm{CueR}$ kísérletileg meghatározott kristályszerkezete (1Q06) [2] a CueR geometriailag optimalizált fémionkötő régiójával átfedésben ábrázolva $\left(\mathbf{A}:{ }^{112}\right.$ Cys deprotonált oldallánci tiolcsoporttal és $\mathbf{B}$ :

${ }^{112}$ Cys protonált oldallánci tiolcsoporttal.) 
Az optimalizálás során kizárólag a színnel jelzett atomok, a ${ }^{112} \mathrm{Cys}$ és ${ }^{120} \mathrm{Cys}, \mathrm{az} \mathrm{Ag}^{+}-$ ion és a másik monomeregységről származó ${ }^{77}$ Ser relaxációját engedélyezték. A kísérletileg meghatározott szerkezethez nagyon hasonló eredmény született, amikor a számolásokban mindkét cisztein deprotonált formában volt jelen a fémkötő régióban (5.4.4.3. ábra, $A$ ). Azonban ha a ${ }^{112}$ Cys protonált (5.4.4.3. ábra, B), jelentősen megváltozik a fémion koordinációs környezete, ugyanis ez a csoport a ${ }^{77}$ Ser alegységet 0,2-0,4 Å-mel közelebb „húzza” a fémkötő helyhez. Ezen kívül jelentősebb változás a kísérletileg meghatározott szerkezethez képest nem történt. Ezek alapján a fehérjében is elképzelhető, hogy egy protonált tiolcsoport koordinálódása jelentős szerepet játszik az egyértékü féminokra való szelektivitásban, a fémionok érzékelésében. 


\section{6. Összefoglalás}

A bakteriális fémion-homeosztázisban fontos szerepet játszanak a transzkripciós regulátorfehérjék. A fémkötő régiójuk szerkezetének eltérései teszik őket szelektívvé a fémionokkal szemben. Ilyen szabályozó molekulák a $\mathrm{Hg}^{2+}$-érzékeny $\mathrm{MerR}, \mathrm{Zn}^{2+}$-szelektív ZntR, vagy az egyértékű fémionok koncentrációjának szabályozásában résztvevő CueR fehérjék. Disszertációmban két bakteriális eredetű CueR fehérje fémkötő doménjét és annak variánsait vizsgáltam peptidmodelleken keresztül.

A ligandumok sikeres előállítását követően egy-, illetve kétértékü fémionokkal végeztünk méréseket. Vizsgálataink során azt tapasztaltuk, hogy a különböző geometriájú komplexek képződése a fémion karakterén túl, a ligandum nagyfokú szerkezeti flexibilitásától is függ.

A modellpeptidek vizsgálatai alapján fiziológiás $\mathrm{pH}-\mathrm{n}$ domináns részecske $\mathrm{ML}$ összetételü. Megállapítottuk, hogy ebben a komplexben a dodekapeptidek egy hurkot képezve, a ${ }^{2}$ Cys és ${ }^{9}$ Cys részvételével kötődnek a vizsgált kétértékü $\mathrm{d}^{10}$ fémionokhoz, hasonlóan a fehérje fémkötő részéhez. Sikeresen bizonyítottuk, hogy míg a $\mathrm{Zn}^{2+}$ - és $\mathrm{Cd}^{2+}$ ionok koordinálásában a peptidekben jelenlévő Asp aminosavak karboxilátcsoportjai is részt vesznek, addig $\mathrm{Hg}^{2+}$-ionok jelenlétében kizárólag $\left\{2 \times \mathrm{S}^{-}\right\}$típusú kötés alakul ki, amit PAC

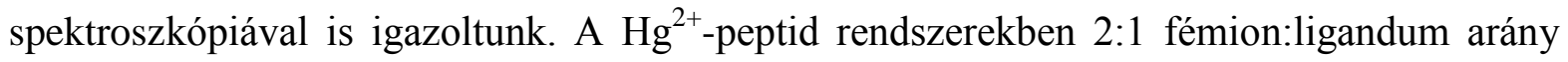
esetén többmagvú komplexek is képződhetnek, amit a PAC spektroszkópiai vizsgálatok mellett CD és ${ }^{1} \mathrm{H}$ NMR mérésekkel is megerősítettünk.

A $\mathrm{ZnL}$ és $\mathrm{CdL}$ törzskomplexeinek deprotonálódása lúgos közegben $\mathrm{ZnH}_{-1} \mathrm{~L}$, ill. $\mathrm{CdH}_{-1} \mathrm{~L}$ összetételü részecskék kialakulásához vezet, melyet a fémionok részleges hidrolíziseként, azaz hidroxo-vegyesligandumú komplexek képződéseként értelmeztünk. $\mathrm{Zn}^{2+}$-ionok esetében ezek a folyamatok már $\mathrm{pH}=8$ körül megkezdődnek, míg a CdL hidrolízise csak $\mathrm{pH}=9$ felett játszódik le.

A bakteriális fémion-homeosztázisban résztvevő több olyan fehérje is ismert, amelyekben az átmenetifém-ionokhoz kettőnél több tiolátcsoport koordinálódik. Ilyen például a MerR fehérje, melyben a $\mathrm{Hg}^{2+}$-ionokhoz három cisztein kapcsolódik trigonális geometriát kialakítva. Ebből kiindulva megvizsgáltuk, hogy változik-e a képződő komplex szerkezete és stabilitása a ligandumfelesleg alkalmazása mellett potenciálisan koordinálódó további ciszteinek hatására. 
Fémion:ligandum 0,5:1 arány mellett $\mathrm{pH}$-potenciometriás mérésekkel, valamint UVés NMR spektroszkópiával a $\mathrm{Cd}^{2+}$, és $\mathrm{Zn}^{2+}$-tartalmú rendszerekben biszkomplexek képződését tudtuk bizonyítani. Míg a $\mathrm{CdL}_{2} \mathrm{pH}=10$ felett is uralkodó részecske, addig a $\mathrm{ZnL}_{2}$ komplex bázikus körülmények között a $\mathrm{ZnH}_{-1} \mathrm{~L}$ részecskévé alakul. Ennek oka valószínüleg az, hogy a $\mathrm{Zn}^{2+}$-ionok számára a $\left\{4 \times \mathrm{S}^{-}\right\}$típusú koordináció kisebb stabilitást biztosít, mint a $\mathrm{Cd}^{2+}$-komplexekben, s ezért a ligandumfelesleg nem képes meggátolni $\mathrm{pH}=$ 8 felett a $\mathrm{Zn}^{2+}$-ionok részleges hidrolízisét. A ligandumfelesleg hatását $\mathrm{Hg}^{2+}$-ionokat tartalmazó mintákban is megvizsgáltuk, azonban az oldatszerkezet-vizsgálatok alapján biszkomplexek képződését nem tapasztaltuk.

A hisztidint tartalmazó peptid vizsgálatával tanulmányozni tudtuk egy újabb, eltérő típusú potenciális donorcsoport hatását a képződő komplexek szerkezetére, illetve stabilitására. A fémionokhoz kapcsolódó hurok, a $\mathrm{Hg}^{2+}$-ionok kivételével, minden esetben a hisztidin imidazolcsoportjának koordinációjával egészül ki, amit több szerkezetvizsgáló módszerrel is igazoltunk. Ezek alapján az ML törzskomplexekben a peptid $\left\{2 \times \mathrm{S}^{-}, \mathrm{N}_{\mathrm{im}}, \mathrm{X}\right\}$ típusú koordinációval kötődik a fémionokhoz, amelyben X jelölhet Asp karboxilátcsoportot, valamint koordinálódó vizet egyaránt. Érdekes módon a szekvencia módosítása csak a $\mathrm{Zn}^{2+}$ komplexek stabilitásában okozott kismértékü növekedést, azonban a $\mathrm{Cd}^{2+}$-komplexek stabilitása az aminosav-csere következtében nem változott. Ez a $\mathrm{Zn}^{2+}$-ionoknak a hisztidin imidazol nitrogén-donoratomjához való nagyobb affinitásával magyarázható. A hisztidin koordinációja mindkét fémion esetén elősegíti (alacsonyabb $\mathrm{pH}$ felé tolja) a hidroxovegyesligandumú komplexek képződését, összevetve a hisztidint nem tartalmazó peptidekkel.

Méréseink alapján a kétértékü $\mathrm{d}^{10}$ fémionok peptidkomplexeit vizsgálva a következő stabilitási sorrend állapítható meg: $\mathrm{Hg}^{2+}>>\mathrm{Cd}^{2+}>\mathrm{Zn}^{2+} \cdot \mathrm{A} \mathrm{Hg}^{2+}-$ komplexek stabilitásáról csak közvetett módszerrel tudtunk információt nyerni a rendkívül erős kölcsönhatás miatt. Az egyik vegyület $\mathrm{Hg}^{2+}$-kötésére meghatározott látszólagos stabilitási állandó $\left(\lg K^{\prime}=25,7\right.$; $\mathrm{pH}=2,0)$ a $\mathrm{Hg}^{2+}$-ionok kiemelkedő affinitását tükrözi a ligandum tiolcsoportjaihoz, összevetve a $\mathrm{Cd}^{2+}$ - és $\mathrm{Zn}^{2+}$-ionokkal. Ennek tükrében meglepő, hogy a $\mathrm{Hg}^{2+}$-ionok a CueR fehérjében még a kialakított erős kölcsönhatás ellenére sem képesek olyan változásokat indukálni, melyek beindítanák a transzkripció folyamatát.

A CueR egyértékü fémionok érzékelésére alkalmas fehérje fémkötő doménjének modellvegyületei változatos szerkezettel jellemezhető és stabilis komplexeket képeznek kétértékü $\mathrm{d}^{10}$ fémionokkal. 
Míg a $\mathrm{Hg}^{2+}$-komplexekben kivétel nélkül torzult lineáris geometria a meghatározó, addig $\mathrm{Cd}^{2+}$ és $\mathrm{Zn}^{2+}$-ionok esetében a tetraéderes szerkezet kedvezményezett. Az összehasonlítás érdekében a dodekapeptidek $\mathrm{Ag}^{+}$-ionokkal alkotott komplexeit is megvizsgáltuk.

$\mathrm{A} \mathrm{Hg}^{2+}$-ionokhoz hasonlóan a peptidek már savas $\mathrm{pH}-\mathrm{n}(\mathrm{pH}<2)$ is kötődnek az $\mathrm{Ag}^{+}-$ ionhoz. Vizsgálataink során azonban meglepő eredményre jutottunk, ugyanis a ligandumok két tiolcsoportjának szignifikánsan különböző az affinitása $\mathrm{Ag}^{+}$-ionhoz, ellentétben a kétértékü fémionokkal. Spektroszkópiai vizsgálatokkal bizonyítottuk, hogy egy ekvivalens fémion jelenlétében $\mathrm{pH} \sim 7$-ig a ciszteinek tiolcsoportjainak csak egy része kötődik tiolátként, a $\mathrm{Hg}^{2+}$-ionnál is tapasztalt $\left\{2 \times \mathrm{S}^{-}\right\}$típusú koordináció csak a fiziológiás $\mathrm{pH}$ felett válik uralkodóvá. Az alatt azonban akár protonált tiolcsoport koordinációja is lehetséges.

A CueR fémion-szabályzó fehérje szelektivitását tekintve egy protonált formában koordinálódó tiolcsoport jelenléte további hidrogénkötések kialakításával jelentősen befolyásolhatja a fémionkötő domén szerkezetét, ami kulcsfontosságú lehet a fémionszelektivitás kialakulásában. 


\section{Summary}

Transcriptional regulator proteins play an important role in the bacterial metal-ion homeostasis. The metal ion selectivity of these proteins is due to the structural differences observed in their metal binding domains. Representation of such proteins are e.g. the $\mathrm{Hg}^{2+}$ sensitive MerR, $\mathrm{Zn}^{2+}$-selective $\mathrm{ZntR}$ or the copper-regulator CueR protein, which is selective for monovalent metal ions such as $\mathrm{Cu}^{+}, \mathrm{Ag}^{+}, \mathrm{Au}^{+}$. $\mathrm{My}$ dissertation presents the investigation of the metal binding domain of two bacterial CueR proteins and their variants through studies of model peptides.

After successful synthesis of the ligands, various measurements with mono-, and divalent metal ions were carried out. It was found, that the formation of complexes with different geometry depends not only on the characterisctics of the metal ions, but the high structural flexibility of the ligands, too.

At physiological $\mathrm{pH}$ the parent complex ML was shown to be the dominant species, in which the dodecapeptides form a loop and bind to the divalent $\mathrm{d}^{10}$ metal ions through thiolate moieties of the ${ }^{2} \mathrm{Cys}$ and ${ }^{9} \mathrm{Cys}$ residues. This sturcture is very similar to the metal bindig site of $\mathrm{CueR}$, where the $\mathrm{Cu}^{+} / \mathrm{Ag}^{+}$-ions are coordinated by two cysteines in a linear coordination geometry. We successfully demonstrated that the carboxyl groups of Asp amino acids take part in the coordination of $\mathrm{Zn}^{2+}-$ and $\mathrm{Cd}^{2+}$-ions, but observed no sign for the participation of any other side chain donors than those of the two Cys residues in $\mathrm{Hg}^{2+}-$ coordination. The $\left\{2 \times \mathrm{S}^{-}\right\}$type coordination mode in the $\mathrm{Hg}^{2+}$-species was also supported by PAC spectroscopy. Furthermore, polynuclear complexes can be formed, when the $\mathrm{Hg}^{2+}$-ions are in twofold excess over the peptide. These findings have been demonstrated by PAC-, CD- and NMR measurements.

The deprotonation of $\mathrm{ZnL}$ and $\mathrm{CdL}$ complexes led to the formation $\mathrm{ZnH}_{-1} \mathrm{~L}$ and $\mathrm{CdH}_{-1} \mathrm{~L}$ species. This is most likely associated with the deprotonation of a water ligand, leading to mixed hidroxido complexes better described as $\mathrm{M}(\mathrm{OH}) \mathrm{L}$. The $\mathrm{p} K_{\mathrm{a}}$ value determined for the $\mathrm{ZnL}$ complex is ca. 1.0-1.5log units smaller than that of the $\mathrm{Cd}^{2+}$ analogue.

There are several proteins participating in bacterial metal ion homeostasis, in which the transition metal ion is coordinated by more than two Cys thiolate groups. An example is provided by the MerR protein, in which the $\mathrm{Hg}^{2+}$-ion is bound to three thiolates from three Cys residues. One of the donor gruops belongs to the second monomer of the dimeric 
functional unit. Accordingly, we investigated whether the presence of ligand excesss has any effect on the stability and the structure of the complexes, i.e. whether further cysteines from the second ligand can bind to the metal ions. Formation of bis ligand $\mathrm{ZnL}_{2}$ and $\mathrm{CdL}_{2}$ complexes have been demonstrated by $\mathrm{pH}$ potentiometric titrations, and UV- or NMR spectroscopy. Whereas the $\mathrm{CdL}_{2}$ complex is dominant species above $\mathrm{pH} \sim 10$, the $\mathrm{ZnL}_{2}$ complex transforms to $\mathrm{ZnH}_{-1} \mathrm{~L}$ species under alkaline condition. This suggests that the tetrathiolate coordination provides less stability in $\mathrm{Zn}^{2+}$ in comparison with the $\mathrm{Cd}^{2+}$ complexes. Therefore, the use of ligand excess is not able to prevent the partial hydrolysis of $\mathrm{Zn}^{2+}$-ions under alkaline condition. In contrary, formation of $\mathrm{HgL}_{2}$ complex with $\left\{4 \times \mathrm{S}^{-}\right\}$ coordination-type was not observed, as confirmed by UV- and NMR spectroscopy.

To explore the effect of another type of potential donor group on the structure and stability of the complexes, a histidine residue has been introduced in the peptide sequence.

We have confirmed by several spectroscopic techniques that the His imidazole moiety participates in the formation of the loop structure in $\mathrm{Zn}^{2+}$-, and $\mathrm{Cd}^{2+}$-complexes, unlike to the $\mathrm{Hg}^{2+}$-containing species. Based on this, the $\left\{2 \times \mathrm{S}^{-}, \mathrm{N}_{\mathrm{im}}, \mathrm{X}\right\}$ coordination type was suggested for the ML species, where the X may be a carboxylate group from Asp residue or a coordinated water molecule.

Interestingly, the substitution of a ${ }^{3}$ Pro to ${ }^{3} \mathrm{His}$ caused only a slight increase in the stability of $\mathrm{Zn}^{2+}$-complexes, while the stability of CdL complex did not change. This can be explaned by the different affinity of the $\mathrm{Zn}^{2+}$ - and $\mathrm{Cd}^{2+}$-ions to the nitrogen donor atoms. The deprotonation of the bound $\mathrm{H}_{2} \mathrm{O}$ in $\mathrm{M}(\mathrm{HS})$ complexes occurs at a somewhat lower $\mathrm{pH}$ compared to the ML complexes of PP and PS ligands, containing no His residue, indicating that the latter promotes the formation of $\mathrm{M}(\mathrm{OH}) \mathrm{L}$ species.

In general, the stabilities of the studied $\mathrm{d}^{10}$ transition metal ion complexes decrease in the $\mathrm{Hg}^{2+}>\mathrm{Cd}^{2+}>\mathrm{Zn}^{2+}$ order. We determined the apparent stability constant of $\mathrm{Hg}(\mathbf{P S})$ complex by an indirect method to be $\lg K^{\prime}=25.7$ at $\mathrm{pH}=2.0$, reflecting the outstanding affinity between $\mathrm{Hg}^{2+}$-ion and thiolate moiety of Cys residues. In this context, it is surprising that the $\mathrm{Hg}^{2+}$-ion does not induce protein-mediated transcription in CueR.

The peptides, inspired by the metal ion binding domain of the CueR protein, are shown to efficiently bind divalent $\mathrm{d}^{10}$ metal ions, with diverse coordination modes. While the $\mathrm{Hg}^{2+}$ forms a loop structure every time with linear coordination geometry, $\mathrm{Zn}^{2+}$ - and $\mathrm{Cd}^{2+}$ ions favored tetrahedral structure.

To compare the coordination properties of mono-, and divalent $\mathrm{d}^{10}$ metal ions, $\mathrm{Ag}^{+}-$ peptide complexes have been investigated, too. The pH-metric titrations, UV-, CD-, and 
NMR-spectroscopies showed, that the peptides bind $\mathrm{Ag}^{+}$-ions even at low $\mathrm{pH}(\mathrm{pH}<2.0)$, similarly to $\mathrm{Hg}^{2+}$-ions. However, unexpectedly we found that the affinities of the two thiol groups of the peptides have significantly different affinty to the $\mathrm{Ag}^{+}$-ion. Based on spectroscopic studies we demonstrated, that only a fraction of the thiolate groups bound to the metal ion below $\mathrm{pH} \sim 7.0$. The $\left\{2 \times \mathrm{S}^{-}\right\}$type coordination found with $\mathrm{Hg}^{2+}$, was only observed above the physiological $\mathrm{pH}$ in the presence of one equivalent $\mathrm{Ag}^{+}$. We suggest that one of the two Cys residues coordinates to the metal ion via protonated thiol group below that $\mathrm{pH}$.

The interaction of the metal ion with protonated thiol may significantly affect the hydrogen bonding network within the metal ion binding loop and thus, the metal ion selectivity of metalloregulatory CueR protein. 


\section{Irodalomjegyzék}

[1] R.B. Martin, Metal Ion Toxicity, in Encyclopedia of Inorganic Chemistry. 2006, John Wiley \& Sons, Ltd.

[2] A. Changela, K. Chen, Y. Xue, J. Holschen, C.E. Outten, T.V. O'Halloran, and A. Mondragon, Molecular basis of metal-ion selectivity and zeptomolar sensitivity by CueR. Science, 301, 1383-1387, 2003.

[3] M.M. Ibanez, S.K. Checa, and F.C. Soncini, A single serine residue determines selectivity to monovalent metal ions in metalloregulators of the MerR family. Journal of Bacteriology, 197, 1606-1613, 2015.

[4] Z. Ma, F.E. Jacobsen, and D.P. Giedroc, Coordination Chemistry of Bacterial Metal Transport and Sensing. Chemical Reviews, 109, 4644-4681, 2009.

[5] T. Barkay, S.M. Miller, and A.O. Summers, Bacterial mercury resistance from atoms to ecosystems. FEMS Microbiology Reviews, 27, 355-384, 2003.

[6] Y. Nevo and N. Nelson, The NRAMP family of metal-ion transporters. Biochimica et Biophysica Acta, 1763, 609-620, 2006.

[7] P. Courville, R. Chaloupka, and M.F. Cellier, Recent progress in structure-function analyses of Nramp proton-dependent metal-ion transporters. Biochemistry and Cell Biology, 84, 960-978, 2006.

[8] K.M. Papp-Wallace and M.E. Maguire, Manganese transport and the role of manganese in virulence. Annual Review of Microbiology, 60, 187-209, 2006.

[9] S. Eshaghi, D. Niegowski, A. Kohl, D.M. Molina, S.A. Lesley, and P. Nordlund, Crystal structure of a divalent metal ion transporter CorA at 2.9 angstrom resolution. Science, 313, 354-357, 2006.

[10] A.L. Davidson, E. Dassa, C. Orelle, and J. Chen, Structure, function, and evolution of bacterial ATP-binding cassette systems. Microbiology and Molecular Biology Reviews, 72, 317-364, 2008.

[11] D.C. Rees, E. Johnson, and O. Lewinson, ABC transporters: the power to change. Nature Reviews Molecular Cell Biology, 10, 218-227, 2009.

[12] N. Zagorski and D.B. Wilson, Characterization and comparison of metal accumulation in two Escherichia coli strains expressing either CopA or MntA, heavy metal-transporting bacterial P-type adenosine triphosphatases. Applied Biochemistry and Biotechnology, 117, 33-48, 2004.

[13] K. Helbig, C. Bleuel, G.J. Krauss, and D.H. Nies, Glutathione and transition-metal homeostasis in Escherichia coli. Journal of Bacteriology, 190, 5431-5438, 2008.

[14] L. Banci, I. Bertini, S. Ciofi-Baffoni, X.C. Su, G.P. Borrelly, and N.J. Robinson, Solution structures of a cyanobacterial metallochaperone: insight into an atypical copper-binding motif. Journal of Biological Chemistry, 279, 27502-27510, 2004.

[15] C.A. Blindauer, Bacterial metallothioneins: past, present, and questions for the future. Journal of Biological Inorganic Chemistry, 16, 1011-1024, 2011.

[16] G. Henkel and B. Krebs, Metallothioneins: zinc, cadmium, mercury, and copper thiolates and selenolates mimicking protein active site features--structural aspects and biological implications. Chemical Reviews, 104, 801-824, 2004.

[17] P.-A. Binz and J.R. Kägi, Metallothionein: Molecular evolution and classification, in Metallothionein IV, C. Klaassen, Editor. 1999, Birkhäuser Basel. p. 7-13.

[18] M. Mejare and L. Bulow, Metal-binding proteins and peptides in bioremediation and phytoremediation of heavy metals. Trends in Biotechnology, 19, 67-73, 2001. 
[19] B. Montanini, D. Blaudez, S. Jeandroz, D. Sanders, and M. Chalot, Phylogenetic and functional analysis of the Cation Diffusion Facilitator (CDF) family: improved signature and prediction of substrate specificity. BMC Genomics, 8, 107, 2007.

[20] S. Murakami, Multidrug efflux transporter, AcrB--the pumping mechanism. Current Opinion in Structural Biology, 18, 459-465, 2008.

[21] D.P. Giedroc and A.I. Arunkumar, Metal sensor proteins: nature's metalloregulated allosteric switches. Dalton Transactions, 3107-3120, 2007.

[22] T.V. Ohalloran, Transition-Metals in Control of Gene-Expression. Science, 261, 715725, 1993.

[23] M.A. Pennella, J.E. Shokes, N.J. Cosper, R.A. Scott, and D.P. Giedroc, Structural elements of metal selectivity in metal sensor proteins. Proceedings of the National Academy of Sciences of the United States of America, 100, 3713-3718, 2003.

[24] P.A. Lund, S.J. Ford, and N.L. Brown, Transcriptional regulation of the mercuryresistance genes of transposon Tn501. Journal of General Microbiology, 132, 465480, 1986.

[25] T. O'Halloran and C. Walsh, Metalloregulatory DNA-binding protein encoded by the merR gene: isolation and characterization. Science, 235, 211-214, 1987.

[26] J.L. Hobman, J. Wilkie, and N.L. Brown, A design for life: prokaryotic metalbinding MerR family regulators. Biometals, 18, 429-436, 2005.

[27] N.L. Brown, J.V. Stoyanov, S.P. Kidd, and J.L. Hobman, The MerR family of transcriptional regulators. FEMS Microbiology Reviews, 27, 145-163, 2003.

[28] J. Wu and B.P. Rosen, Metalloregulated expression of the ars operon. J Biol Chem, 268, 52-58, 1993.

[29] A.P. Morby, J.S. Turner, J.W. Huckle, and N.J. Robinson, SmtB is a metal-dependent repressor of the cyanobacterial metallothionein gene smtA: identification of a $\mathrm{Zn}$ inhibited DNA-protein complex. Nucleic Acids Research, 21, 921-925, 1993.

[30] L.S. Busenlehner, M.A. Pennella, and D.P. Giedroc, The SmtB/ArsR family of metalloregulatory transcriptional repressors: Structural insights into prokaryotic metal resistance. FEMS Microbiology Reviews, 27, 131-143, 2003.

[31] Y. Wang, L. Hemmingsen, and D.P. Giedroc, Structural and functional characterization of Mycobacterium tuberculosis CmtR, a $\mathrm{Pb}^{I I} / \mathrm{Cd}^{I I}$-sensing SmtB/ArsR metalloregulatory repressor. Biochemistry, 44, 8976-8988, 2005.

[32] T. Liu, X. Chen, Z. Ma, J. Shokes, L. Hemmingsen, R.A. Scott, and D.P. Giedroc, A $\mathrm{Cu}(\mathrm{I})$-sensing ArsR family metal sensor protein with a relaxed metal selectivity profile. Biochemistry, 47, 10564-10575, 2008.

[33] T. Liu, A. Ramesh, Z. Ma, S.K. Ward, L. Zhang, G.N. George, A.M. Talaat, J.C. Sacchettini, and D.P. Giedroc, CsoR is a novel Mycobacterium tuberculosis coppersensing transcriptional regulator. Nature Chemical Biology, 3, 60-68, 2007.

[34] D. Corbett, S. Schuler, S. Glenn, P.W. Andrew, J.S. Cavet, and I.S. Roberts, The combined actions of the copper-responsive repressor $C s o R$ and coppermetallochaperone CopZ modulate CopA-mediated copper efflux in the intracellular pathogen Listeria monocytogenes. Molecular Microbiology, 81, 457-472, 2011.

[35] C. Rademacher and B. Masepohl, Copper-responsive gene regulation in bacteria. Microbiology, 158, 2451-2464, 2012.

[36] D. Strausak and M. Solioz, CopY is a copper-inducible repressor of the Enterococcus hirae copper ATPases. Journal of Biological Chemistry, 272, 8932-8936, 1997.

[37] J.L. Ramos, M. Martinez-Bueno, A.J. Molina-Henares, W. Teran, K. Watanabe, X. Zhang, M.T. Gallegos, R. Brennan, and R. Tobes, The TetR family of transcriptional repressors. Microbiology and Molecular Biology Reviews, 69, 326-356, 2005. 
[38] D. Lucarelli, S. Russo, E. Garman, A. Milano, W. Meyer-Klaucke, and E. Pohl, Crystal structure and function of the zinc uptake regulator FurB from Mycobacterium tuberculosis. Journal of Biological Chemistry, 282, 9914-9922, 2007.

[39] A. Maciag, E. Dainese, G.M. Rodriguez, A. Milano, R. Provvedi, M.R. Pasca, I. Smith, G. Palu, G. Riccardi, and R. Manganelli, Global analysis of the Mycobacterium tuberculosis Zur (FurB) regulon. Journal of Bacteriology, 189, 730740, 2007.

[40] J.S. Iwig, J.L. Rowe, and P.T. Chivers, Nickel homeostasis in Escherichia coli - the rcnR-rcnA efflux pathway and its linkage to NikR function. Molecular Microbiology, 62, 252-262, 2006.

[41] W.G. Reeve, R.P. Tiwari, N.B. Kale, M.J. Dilworth, and A.R. Glenn, ActP controls copper homeostasis in Rhizobium leguminosarum bv. viciae and Sinorhizobium meliloti preventing low pH-induced copper toxicity. Molecular Microbiology, 43, 981-991, 2002.

[42] S.W. Lee, E. Glickmann, and D.A. Cooksey, Chromosomal locus for cadmium resistance in Pseudomonas putida consisting of a cadmium-transporting ATPase and a MerR family response regulator. Applied and Environmental Microbiology, 67, 1437-1444, 2001.

[43] B. Borremans, J.L. Hobman, A. Provoost, N.L. Brown, and D. van Der Lelie, Cloning and functional analysis of the pbr lead resistance determinant of Ralstonia metallidurans CH34. Journal of Bacteriology, 183, 5651-5658, 2001.

[44] J.C. Rutherford, J.S. Cavet, and N.J. Robinson, Cobalt-dependent transcriptional switching by a dual-effector MerR-like protein regulates a cobalt-exporting variant CPx-type ATPase. Journal of Biological Chemistry, 274, 25827-25832, 1999.

[45] J.V. Stoyanov, J.L. Hobman, and N.L. Brown, CueR (YbbI) of Escherichia coli is a MerR family regulator controlling expression of the copper exporter CopA. Molecular Microbiology, 39, 502-511, 2001.

[46] M. Noll, K. Petrukhin, and S. Lutsenko, Identification of a novel transcription regulator from Proteus mirabilis, PMTR, revealed a possible role of YJAI protein in balancing zinc in Escherichia coli. Journal of Biological Chemistry, 273, 21393$21401,1998$.

[47] J.S. Kim, M.H. Kim, M.H. Joe, S.S. Song, I.S. Lee, and S.Y. Choi, The sctR of Salmonella enterica serova Typhimurium encoding a homologue of MerR protein is involved in the copper-responsive regulation of cuiD. FEMS Microbiology Letters, 210, 99-103, 2002.

[48] F.W. Outten, C.E. Outten, J. Hale, and T.V. O'Halloran, Transcriptional activation of an Escherichia coli copper efflux regulon by the chromosomal MerR homologue, CueR. Journal of Biological Chemistry, 275, 31024-31029, 2000.

[49] K.R. Brocklehurst, J.L. Hobman, B. Lawley, L. Blank, S.J. Marshall, N.L. Brown, and A.P. Morby, ZntR is a Zn(II)-responsive MerR-like transcriptional regulator of zntA in Escherichia coli. Molecular Microbiology, 31, 893-902, 1999.

[50] P.R. Chen and C. He, Selective recognition of metal ions by metalloregulatory proteins. Current Opinion in Chemical Biology, 12, 214-221, 2008.

[51] Q. Zeng, C. Stalhandske, M.C. Anderson, R.A. Scott, and A.O. Summers, The core metal-recognition domain of MerR. Biochemistry, 37, 15885-15895, 1998.

[52] J.G. Wright, M.J. Natan, F.M. MacDonnel, D.M. Ralston, and T.V. O'Halloran, Mercury(II)-Thiolate Chemistry and the Mechanism of the Heavy Metal Biosensor MerR, in Progress in Inorganic Chemistry. 1990, John Wiley \& Sons, Inc. p. 323412. 
[53] J.D. Helmann, B.T. Ballard, and C.T. Walsh, The MerR metalloregulatory protein binds mercuric ion as a tricoordinate, metal-bridged dimer. Science, 247, 946-948, 1990.

[54] L.M. Utschig, J.W. Bryson, and T.V. O'Halloran, Mercury-199 NMR of the metal receptor site in MerR and its protein-DNA complex. Science, 268, 380-385, 1995.

[55] D.L. Huffman, L.M. Utschig, and T.V. O'Halloran, Mercury-responsive gene regulation and mercury-199 as a probe of protein structure. Metal Ions in Biological System, 34, 503-526, 1997.

[56] D.M. Ralston and T.V. O'Halloran, Ultrasensitivity and heavy-metal selectivity of the allosterically modulated MerR transcription complex. Proceedings of the National Academy of Sciences of the United States of America, 87, 3846-3850, 1990.

[57] A.Z. Ansari, M.L. Chael, and T.V. O'Halloran, Allosteric underwinding of DNA is a critical step in positive control of transcription by Hg-MerR. Nature, 355, 87-89, 1992.

[58] A.Z. Ansari, J.E. Bradner, and T.V. O'Halloran, DNA-bend modulation in a repressor-to-activator switching mechanism. Nature, 374, 371-375, 1995.

[59] C. Rensing, M. Ghosh, and B.P. Rosen, Families of soft-metal-ion-transporting ATPases. Journal of Bacteriology, 181, 5891-5897, 1999.

[60] S.J. Beard, R. Hashim, J. Membrillo-Hernandez, M.N. Hughes, and R.K. Poole, Zinc(II) tolerance in Escherichia coli $K$-12: evidence that the zntA gene (o732) encodes a cation transport ATPase. Molecular Microbiology, 25, 883-891, 1997.

[61] M.R.B. Binet and R.K. Poole, $C d(I I), P b(I I)$ and $\mathrm{Zn}(I I)$ ions regulate expression of the metal-transporting P-type ATPase ZntA in Escherichia coli. Febs Letters, 473, 67-70, 2000.

[62] G.E. Christie, T.J. White, and T.S. Goodwin, A merR homologue at 74 minutes on the Escherichia coli genome. Gene, 146, 131-132, 1994.

[63] C.E. Outten and T.V. O'Halloran, Femtomolar sensitivity of metalloregulatory proteins controlling zinc homeostasis. Science, 292, 2488-2492, 2001.

[64] S. Khan, K.R. Brocklehurst, G.W. Jones, and A.P. Morby, The functional analysis of directed amino-acid alterations in ZntR from Escherichia coli. Biochemical and Biophysical Research Communications, 299, 438-445, 2002.

[65] C. Rensing, B. Fan, R. Sharma, B. Mitra, and B.P. Rosen, CopA: An Escherichia coli $\mathrm{Cu}(\mathrm{I})$-translocating P-type ATPase. Proceedings of the National Academy of Sciences of the United States of America, 97, 652-656, 2000.

[66] G. Grass and C. Rensing, CueO is a multi-copper oxidase that confers copper tolerance in Escherichia coli. Biochemical and Biophysical Research Communications, 286, 902-908, 2001.

[67] C. Petersen and L.B. Moller, Control of copper homeostasis in Escherichia coli by a P-type ATPase, CopA, and a MerR-like transcriptional activator, CopR. Gene, 261, 289-298, 2000.

[68] A.E. Martell and R.M. Smith, Critical stability constants. 1974, New York,: Plenum Press. v. 1-6.

[69] R. Osterberg, R. Ligaarden, and D. Persson, Copper(I) complexes of penicillamine and glutathione. Journal of Inorganic Biochemistry, 10, 341-355, 1979.

[70] K. Chen, S. Yuldasheva, J.E. Penner-Hahn, and T.V. O'Halloran, An atypical linear $\mathrm{Cu}(\mathrm{I})-\mathrm{S}_{2}$ center constitutes the high-affinity metal-sensing site in the CueR metalloregulatory protein. Journal of American Chemical Society, 125, 1208812089, 2003. 
[71] T. Kortemme and T.E. Creighton, Ionization of Cysteine Residues at the Termini of Model Alpha-Helical Peptides - Relevance to Unusual Thiol $p K_{a}$ Values in Proteins of the Thioredoxin Family. Journal of Molecular Biology, 253, 799-812, 1995.

[72] I. Sóvágó, C. Kállay, and K. Várnagy, Peptides as complexing agents: Factors influencing the structure and thermodynamic stability of peptide complexes. Coordination Chemistry Reviews, 256, 2225-2233, 2012.

[73] J.G. Smith, Organic chemistry. 3rd ed. 2011, New York, NY: McGraw-Hill. xxxiv, 1178 p., 1167 p.

[74] F. Jalilehvand, Z. Amini, K. Parmar, and E.Y. Kang, Cadmium(II) N-acetylcysteine complex formation in aqueous solution. Dalton Transactions, 40, 12771-12778, 2011.

[75] F. Jalilehvand, B.O. Leung, M. Izadifard, and E. Damian, Mercury(II) cysteine complexes in alkaline aqueous solution. Inorganic Chemistry, 45, 66-73, 2006.

[76] F. Jalilehvand, B.O. Leung, and V. Mah, Cadmium(II) complex formation with cysteine and penicillamine. Inorganic Chemistry, 48, 5758-5771, 2009.

[77] F. Jalilehvand, K. Parmar, and S. Zielke, Mercury(II) complex formation with Nacetylcysteine. Metallomics, 5, 1368-1376, 2013.

[78] B.O. Leung, F. Jalilehvand, and V. Mah, Mercury(II) penicillamine complex formation in alkaline aqueous solution. Dalton Transaction, 4666-4674, 2007.

[79] W.E. van der Linden and C. Beers, Determination of the composition and the stability constants of complexes of mercury (II) with amino acids. Analytical Chimica Acta, 68, 143-154, 1974.

[80] I. Sóvágó, A. Gergely, B. Harman, and T. Kiss, Complexes of sulphur-containing ligands-II: Binary and ternary complexes of D-penicillamine and L-cysteine with nickel(II) and zinc(II) ions. Journal of Inorganic and Nuclear Chemistry, 41, 16291633, 1979.

[81] L.D. Pettit, K.F. Siddiqui, H. Kozlowski, and T. Kowalik, Potentiometric and H-1$\mathrm{Nmr}$ Studies on Silver(I) Interaction with S-Methyl-L-Cysteine, S-Methyl-LMethionine and S-Methyl-L-Ethionine. Inorganica Chimica Acta-Bioinorganic Chemistry, 55, 87-91, 1981.

[82] J.J. Tombeux, J. Schaubroeck, C.T. Huys, H.F. Debrabander, and A.M. Goeminne, A Potentiometric Study of the Agi Complexes of Some Sulfur-Containing Amino-Acids. Zeitschrift Fur Anorganische Und Allgemeine Chemie, 517, 235-240, 1984.

[83] B.O. Leung, F. Jalilehvand, V. Mah, M. Parvez, and Q. Wu, Silver(I) complex formation with cysteine, penicillamine, and glutathione. Inorganic Chemistry, 52, 4593-4602, 2013.

[84] J.R.K. F. Caron, Silver Complexes of Environmental and Related Thiols: Structural Studies. Analytical Chemistry, 114-118, 1989.

[85] H. Adachi, N. Ueyama, and A. Nakamura, 199Hg NMR investigation on the solution structure of $\mathrm{Hg}(\mathrm{II})$ complexes of oligopeptides containing cysteine and histidine residues, Inorganica Chimica Acta. 805-811, 1992.

[86] A. Krezel and W. Bal, Studies of zinc(II) and nickel(II) complexes of GSH, GSSG and their analogs shed more light on their biological relevance. Bioinorganic Chemistry and Applications, 2, 293-305, 2004.

[87] V. Mah and F. Jalilehvand, Cadmium(II) complex formation with glutathione. Journal of Biological Inorganic Chemistry, 15, 441-458, 2010.

[88] P.D. Oram, X. Fang, Q. Fernando, P. Letkeman, and D. Letkeman, The formation of constants of mercury(II)-glutathione complexes. Chemical Research in Toxicology, 9, 709-712, 1996. 
[89] V. Mah and F. Jalilehvand, Mercury(II) complex formation with glutathione in alkaline aqueous solution. Journal of Biological Inorganic Chemistry, 13, 541-553, 2008.

[90] V. Mah and F. Jalilehvand, Glutathione complex formation with mercury(II) in aqueous solution at physiological pH. Chemical Research in Toxicology, 23, 1815$1823,2010$.

[91] V. Dorcak and A. Krezel, Correlation of acid-base chemistry of phytochelatin PC2 with its coordination properties towards the toxic metal ion Cd(II). Dalton Transactions, 2253-2259, 2003.

[92] R. Kobayashi and E. Yoshimura, Differences in the binding modes of phytochelatin to cadmium (II) and Zinc(II) ions. Biological Trace Element Research, 114, 313-318, 2006.

[93] H. Satofuka, T. Fukui, M. Takagi, H. Atomi, and T. Imanaka, Metal-binding properties of phytochelatin-related peptides. Journal of Inorganic Biochemistry, 86, 595-602, 2001.

[94] W. Bae and R.K. Mehra, Metal-binding characteristics of a phytochelatin analog (Glu-Cys $)_{2}$ Gly. Journal of Inorganic Biochemistry, 68, 201-210, 1997.

[95] W. Lu, A.J. Zelazowski, and M.J. Stillman, Mercury binding to metallothioneins:

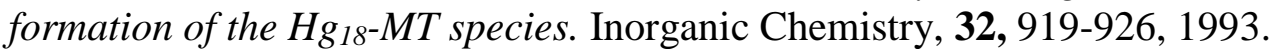

[96] D.W. Hasler, L.T. Jensen, O. Zerbe, D.R. Winge, and M. Vašák, Effect of the Two Conserved Prolines of Human Growth Inhibitory Factor (Metallothionein-3) on Its Biological Activity and Structure Fluctuation: Comparison with a Mutant Protein. Biochemistry, 39, 14567-14575, 2000.

[97] M.J. Stillman, Spectroscopic studies of copper and silver binding to metallothioneins. Metal-Based Drugs, 6, 277-290, 1999.

[98] X. Li, K. Suzuki, K. Kanaori, K. Tajima, A. Kashiwada, H. Hiroaki, D. Kohda, and T. Tanaka, Soft metal ions, Cd(II) and Hg(II), induce triple-stranded alpha-helical assembly and folding of a de novo designed peptide in their trigonal geometries. Protein Science, 9, 1327-1333, 2000.

[99] O. Iranzo, P.W. Thulstrup, S.B. Ryu, L. Hemmingsen, and V.L. Pecoraro, The application of (199) Hg NMR and $(199 \mathrm{~m}) \mathrm{Hg}$ perturbed angular correlation (PAC) spectroscopy to define the biological chemistry of $\mathrm{Hg}(\mathrm{II})$ : a case study with designed two- and three-stranded coiled coils. Chemistry, 13, 9178-9190, 2007.

[100] M. Matzapetakis, B.T. Farrer, T.C. Weng, L. Hemmingsen, J.E. Penner-Hahn, and V.L. Pecoraro, Comparison of the binding of cadmium(II), mercury(II), and arsenic(III) to the de novo designed peptides TRI L12C and TRI L16C. Journal of American Chemical Society, 124, 8042-8054, 2002.

[101] O. Iranzo, T. Jakusch, K.H. Lee, L. Hemmingsen, and V.L. Pecoraro, The correlation of ${ }^{113} C d N M R$ and ${ }^{111 m}$ Cd PAC spectroscopies provides a powerful approach for the characterization of the structure of Cd(II)-substituted Zn(II) proteins. Chemistry, 15, 3761-3772, 2009.

[102] M. Łuczkowski, M. Stachura, V. Schirf, B. Demeler, L. Hemmingsen, and V.L. Pecoraro, Design of Thiolate Rich Metal Binding Sites within a Peptidic Framework. Inorganic Chemistry, 47, 10875-10888, 2008.

[103] V. Magafa, G. Stavropoulos, P. Tsiveriotis, and N. Hadjiliadis, Interaction of $\mathrm{Hg}(I I)$ with tetrapeptides containing cysteinyl and histidinyl residues. Inorganica Chimica Acta, 272, 7-17, 1998.

[104] K. Kulon, D. Wozniak, K. Wegner, Z. Grzonka, and H. Kozlowski, Specific interactions of metal ions with Cys-Xaa-Cys unit inserted into the peptide sequence. Journal of Inorganic Biochemistry, 101, 1699-1706, 2007. 
[105] N. Lihi, A. Grenacs, S. Timari, I. Turi, I. Banyai, I. Sovago, and K. Varnagy, Zinc(II) and cadmium(II) complexes of $N$-terminally free peptides containing two separate cysteinyl binding sites. New Journal of Chemistry, 39, 8364-8372, 2015.

[106] P. Gockel, M. Gelinsky, R. Vogler, and H. Vahrenkamp, Solution behaviour and zinc complexation of tripeptides with cysteine and/or histidine at both termini. Inorganica Chimica Acta, 272, 115-124, 1998.

[107] R. Vogler, M. Gelinsky, L.F. Guo, and H. Vahrenkamp, Solution behaviour and zinc complexation of di-and tripeptides with two cysteine units. Inorganica Chimica Acta, 339, 1-8, 2002.

[108] K. Krzywoszynska, M. Rowinska-Zyrek, D. Witkowska, S. Potocki, M. Luczkowski, and $\mathrm{H}$. Kozlowski, Polythiol binding to biologically relevant metal ions. Dalton Transactions, 40, 10434-10439, 2011.

[109] M. Rowinska-Zyrek, D. Witkowska, S. Bielinska, W. Kamysz, and H. Kozlowski, The-Cys-Cys- motif in Helicobacter pylori's Hpn and HspA proteins is an essential anchoring site for metal ions. Dalton Transactions, 40, 5604-5610, 2011.

[110] S. Potocki, M. Rowinska-Zyrek, D. Valensin, K. Krzywoszynska, D. Witkowska, M. Luczkowski, and $\mathrm{H}$. Kozlowski, Metal binding ability of cysteine-rich peptide domain of ZIP13 Zn ${ }^{2+}$ ions transporter. Inorganic Chemistry, 50, 6135-6145, 2011.

[111] E. Kaiser, R.L. Colescott, C.D. Bossinger, and P.I. Cook, Color test for detection of free terminal amino groups in the solid-phase synthesis of peptides. Analytical Biochemistry, 34, 595-598, 1970.

[112] W. Liptay, F. J. C. Rossotti and H. Rossotti, The Determination of Stability Constants and Other Equilibrium Constants in Solution, McGraw-Hill Book Company, Inc., New York, Toronto, London 1961 (Series in Advanced Chemistry), 425 Seiten. Preis: 97 s. Zeitschrift für Elektrochemie, Berichte der Bunsengesellschaft für physikalische Chemie, 66, 280-280, 1962.

[113] R. Parsons, Stability Constants of Metal-Ion Complexes. Part A. Inorganic Chemistry. Journal of Electroanalytical Chemistry and Interfacial Electrochemistry, 148, 307, 1983.

[114] I.N. L. Zekany, G. Peintler, PSEQUAD for Chemical Equilibria, in Technical Software Distributors. 1991.

[115] L. Hemmingsen and T. Butz, Perturbed Angular Correlations of $\gamma$-rays (PAC) Spectroscopy, in Encyclopedia of Inorganic and Bioinorganic Chemistry. 2011, John Wiley \& Sons, Ltd.

[116] V. Arcisauskaite, S. Knecht, S.P. Sauer, and L. Hemmingsen, Electric field gradients in Hg compounds: molecular orbital (MO) analysis and comparison of 4-component and 2-component (ZORA) methods. Phys Chem Chem Phys, 14, 16070-16079, 2012.

[117] R.J. Beynon and J.S. Easterby, Buffer solutions. The basics. 1996, Oxford ; New York: IRL Press at Oxford University Press. VIII, $84 \mathrm{p}$.

[118] N.A. Rey, O.W. Howarth, and E.C. Pereira-Maia, Equilibrium characterization of the As(III)-cysteine and the As(III)-glutathione systems in aqueous solution. Journal of Inorganic Biochemistry, 98, 1151-1159, 2004.

[119] A. Kolozsi, A. Lakatos, G. Galbacs, A.O. Madsen, E. Larsen, and B. Gyurcsik, A pHmetric, $U V, N M R$, and $X$-ray crystallographic study on arsenous acid reacting-with dithioerythritol. Inorganic Chemistry, 47, 3832-3840, 2008.

[120] M. Vasak, J.H.R. Kagi, and H.A.O. Hill, Zinc(Ii), Cadmium(Ii), and Mercury(Ii) Thiolate Transitions in Metallothionein. Biochemistry, 20, 2852-2856, 1981. 
[121] P. Andersson, J. Kvassman, A. Lindström, B. Olden, and G. Pettersson, Evidence that Ionization of Zinc-Bound Water Regulates the Anion-Binding Capacity of the Coenzyme-Binding Site in Liver Alcohol Dehydrogenase. European Journal of Biochemistry, 108, 303-312, 1980.

[122] L. Hemmingsen, R. Bauer, M.J. Bjerrum, M. Zeppezauer, H.W. Adolph, G. Formicka, and E. Cedergrenzeppezauer, Cd-Substituted Horse Liver AlcoholDehydrogenase - Catalytic Site Metal Coordination Geometry and Protein Conformation. Biochemistry, 34, 7145-7153, 1995.

[123] J.H.R. Kagi, M. Vasak, K. Lerch, D.E.O. Gilg, P. Hunziker, W.R. Bernhard, and M. Good, Structure of Mammalian Metallothionein. Environmental Health Perspectives, 54, 93-103, 1984.

[124] L.M. Utschig, J.G. Wright, and T.V. Ohalloran, Biochemical and Spectroscopic Probes of Mercury(II) Coordination Environments in Proteins. Metallobiochemistry, Part C, 226, 71-97, 1993.

[125] T. Butz, W. Troger, T. Pohlmann, and O. Nuyken, The Nuclear-Quadrupole Interaction of Hg-199m-Cysteine and Hg-199m-Tert-Butyl-Mercaptide. Zeitschrift Fur Naturforschung Section a-a Journal of Physical Sciences, 47, 85-88, 1992.

[126] W. Troger, Nuclear probes in life sciences. Hyperfine Interactions, 120, 117-128, 1999.

[127] P. Faller, B. Ctortecka, W. Troger, T. Butz, and M. Vasak, Optical and TDPAC spectroscopy of $\mathrm{Hg}(\mathrm{II})$-rubredoxin: model for a mononuclear tetrahedral $\left[\mathrm{Hg}(\mathrm{CysS})_{4}\right]_{2^{-}}$center. ISOLDE Collaboration. Journal of Biological Inorganic Chemistry, 5, 393-401, 2000.

[128] L.G. Sillén, Electrometic Investigation of Equilibria between Mercury and Halogen Ions. VIII. Survey and Conclusions. Acta Chemica Scandinavica, 3, 539-553, 1949.

[129] T.R. Griffiths and R.A. Anderson, The electronic spectra of the mixed mercury dihalides. Part 2. Identification, equilibrium and formation constants, and assignment of transitions. Journal of the Chemical Society, Dalton Transactions, 209-215, 1980.

[130] S. Pires, J. Habjanic, M. Sezer, C.M. Soares, L. Hemmingsen, and O. Iranzo, Design of a peptidic turn with high affinity for $\mathrm{Hg}(I I)$. Inorganic Chemistry, 51, 1133911348, 2012.

[131] K.L. Bren, Nuclear Magnetic Resonance (NMR) Spectroscopy of Metallobiomolecules, in Encyclopedia of Inorganic and Bioinorganic Chemistry. 2011, John Wiley \& Sons, Ltd.

[132] M.R. Jensen, M.A. Hass, D.F. Hansen, and J.J. Led, Investigating metal-binding in proteins by nuclear magnetic resonance. Cell Mol Life Sci, 64, 1085-1104, 2007.

[133] P.W. Atkins and J. De Paula, Atkins' Physical chemistry. 9th ed. 2010, Oxford ; New York: Oxford University Press. xxix, 972 p.

[134] S. Pires, J. Habjanic, M. Sezer, C.M. Soares, L. Hemmingsen, and O. Iranzo, Design of a peptidic turn with high affinity for $\mathrm{Hg}(I I)$. Inorganic Chemistry, 51, 1133911348, 2012.

[135] A. Bharti, P. Bharati, M.K. Bharty, R.K. Dani, S. Singh, and N.K. Singh, Mononuclear Ag(I), dinuclear and polymeric Hg(II) complexes of 3-mercapto-4methyl-4H-1,2,4-triazole: Syntheses, spectral, X-ray, photoluminescence and thermal analysis. Polyhedron, 54, 131-139, 2013. 


\section{Közlemények listája}

1. Dániel Szunyogh, Hajnalka Szokolai, Peter W. Thulstrup, Flemming H. Larsen, Béla Gyurcsik, Niels Johan Christensen, Monika Stachura, Lars Hemmingsen, and Attila Jancsó: Specificity of the Metalloregulator CueR for Monovalent Metal Ions: Possible Functional Role of a Coordinated Thiol?

Angewandte Chemie International Edition, 54, 15756-15761, 2015.

IF.: 11,261

2. Dániel Szunyogh, Béla Gyurcsik, Flemming H. Larsen, Monika Stachura, Peter W. Thulstrup, Lars Hemmingsen, Attila Jancsó: Zn(II) and Hg(II) binding to a designed peptide that accommodates different coordination geometries Dalton Transactions, 44, 12576-12588, 2015.

IF.: 4,197

3. Attila Jancsó, Dániel Szunyogh, Flemming H. Larsen, Peter W. Thulstrup, Niels Johan Christensen, Béla Gyurcsik and Lars Hemmingsen: Towards the role of metal ions in the structural variability of proteins: $\mathrm{Cd}$ (II) speciation of a metalion binding loop motif

Metallomics, 3, 1331-1339, 2011.

IF.: $\mathbf{3 , 5 8 5}$

A dolgozat témaköréhez közvetlenül nem kapcsolódó közlemények $\Sigma$ IF.: 6,863

1. Alexander Gottberg, Monika Stachura, Magdalena Kowalska, Mark L. Bissell, Vaida Arcisauskaite, Klaus Blaum, Alexander Helmke, Karl Johnston, Kim Kreim, Flemming H. Larsen, Rainer Neugart, Gerda Neyens, Daniel Szunyogh, Peter W. Thulstrup, Deyan T. Yordanov and Lars Hemmingsen: Billion Time Enhanced Sensitivity of NMR Spectroscopy for Magnesium Ions in Solution

ChemphysChem, 15, 3929-3932, 2014.

IF.: 3,419

2. Dávid Árus, Attila Jancsó, Dániel Szunyogh, Ferenc Matyuska, Nóra Veronika Nagy, Eufrozina Hoffmann, Tamás Körtvélyesi, Tamás Gajda: On the possible roles of $\mathbf{N}$ terminal His-rich domains of $\mathrm{Cu}, \mathrm{Zn}$ SODs of some Gram-negative bacteria Journal of Inorganic Biochemistry, 106, 10-18, 2012.

IF.: 3,444 


\section{$\underline{\text { A dolgozat anyagához kapcsolódó előadások, poszterek }}$}

Nemzetközi konferencia részvétel (szerzö/társszerzö)

1. A. Jancsó, B. Gyurcsik, D. Szunyogh, A. Angyal, L. Hemmingsen: Mercury(II)interaction of dodecapeptides designed for the sequestering of toxic metal ions.

$10^{\text {th }}$ European Biological Inorganic Chemistry Conference, Thessaloniki, Greece, 22$26^{\text {th }}$ June, 2010.

2. L. Hemmingsen, A. Jancsó, D. Szunyogh, F.H. Larsen, P.W. Thulstrup, N.J. Christensen, B. Gyurcsik: Metal Ion Controlled Polymorphism of a Peptide. $3^{\text {rd }}$ International Symposium on Metallomics, Münster, Germany, 15-18 ${ }^{\text {th }}$ June, 2011.

3. A. Jancsó, B. Gyurcsik, D. Szunyogh, A. Angyal, L. Szekeres, L. Hemmingsen, F.H. Larsen, P.W. Thulstrup, N.J. Christensen: Cadmium(II) and mercury(II) binding of cysteine containing oligopeptides designed for the sequestering of toxic metal ions.

$4^{\text {th }}$ European Conference on Chemistry for Life Sciences (4 ${ }^{\text {th }}$ ECCLS), Budapest, Hungary, August 31- September 3, 2011.

4. A. Jancsó, D. Szunyogh, A. Cserkó, Cserkó, B. Gyurcsik, L. Hemmingsen, P.W. Thulstrup,F.H. Larsen: Capture and bioaccumulation of toxic metal ions by oligopeptides inspired by the metal binding loop of CueR metalloregulatory proteins.

$5^{\text {th }}$ International IMBG Meeting on Metal Homeostasis, Autrans, France September 17$21^{\text {th }}, 2012$.

5. H. Szokolai, D. Szunyogh, L. Rózsahegyi, A. Jancsó, B. Gyurcsik, L. Hemmingsen, P. W. Thulstrup, F. H. Larsen: Metal ion binding study of a dodecamer peptide representing the effector binding loop of a metalloregulatory protein.

REGIONAL CONFERENCE "Heavy metal as contaminants of the environments" Timisoara, Romania, $17^{\text {th }}$ May, 2013.

6. D. Szunyogh, A. Jancsó, H. Szokolai, L. Rózsahegyi, B. Gyurcsik, L. Hemmingsen, P.W. Thulstrup, F.H. Larsen: Interaction of $\mathrm{d}^{10}$ metal ions with a 12-mer peptide comprising the metal binding domain of a CueR metalloregulatory protein $5^{\text {th }}$ European Conference on Chemistry for Life Sciences $\left(5^{\text {th }}\right.$ ECCLS), Barcelona, Spain, 10-12 $2^{\text {th }}$, June, 2013.

7. A. Jancsó, H. Szokolai, L. Rozsahegyi, D. Szunyogh, L. Hemmingsen, P.W. Thulstrup, F. H. Larsen: Metal ion interaction of an oligopeptide fragment representing the regulatory metal binding site of a CueR protein

International Conference on BioInorganic Chemistry (16 ${ }^{\text {th }}$ ICBIC), Grenoble, Spain, 22$26^{\text {th }}$, July, 2013. 
8. D. Szunyogh, A. Jancsó, B. Gyurcsik, L. Hemmingsen, P. W. Thulstrup, F. H. Larsen: Metal ion induced structural diversity of the metal binding domain from E. Coli CueR regulatory protein

$12^{\text {th }}$ European Biological Inorganic Chemistry Conference (12 ${ }^{\text {th }}$ EUROBIC), Zürich, Switzerland, 24-28 ${ }^{\text {th }}$, August, 2014.

9. D. Szunyogh, A. Jancsó, B. Gyurcsik: SRCD studies on metal ion binding of oligopeptides

Synchrotron Radiation Circular Dichroism Spectroscopy at the Physikzentrum Bad Honnef, Bad Honnef, Germany, 17-20 ${ }^{\text {th }}$, May, 2015.

\section{Hazai konferencia részvétel (szerzö/társszerzö)}

1. Jancsó A., Gyurcsik B., Szunyogh D., Angyal A., Hemmingsen L.: Toxikus fémionok eltávolítására tervezett dodekapeptidek higany(II)ionokkal való kölcsönhatása XLV. Komplexkémiai Kollokvium, május 26-28, Mátraháza, 2010.

2. Jancsó A., Gyurcsik B., Szunyogh D., Angyal A., Szekeres L., Hemmingsen L., Larsen F.: Kadmium(II)- és higany(II)ionok kölcsönhatása toxikus fémionok megkötésére tervezett oligopeptidekkel

MKE 1. Nemzeti Konferencia, május 22-25, Sopron, 2011.

3. Jancsó A., Gyurcsik B., Szunyogh D., Angyal A.:Toxikus fémionok hatékony megkötése oligopeptidekkel

Az MTA Bolyai János Kutatási Ösztöndijas szegedi kutatók és az Információs Társadalom jogi alprogram kutatóinak tudományos konferenciája, december 9, Szeged, 2011.

4. Szunyogh D., Cserkó A., Gyurcsik B., Jancsó A.:Toxikus fémionok eltávolítására felkészített baktériumok elöállítása, valamint fémion toleranciájuk vizsgálata XLVI. Komplexkémiai Kollokvium, május 21-23, Mátrafüred, 2012.

5. Jancsó A., Gyurcsik B., Szunyogh D., Hemmingsen L., Thulstrup P. W., Larsen F. H., Christensen N. J.: Oligopeptide sequences of the metal binding domain of CueR metalloregulatory proteins as candidates for toxic metal-ion capture.

The International Symposium on Analytical and Environmental Problems, with Special Emphasis on Heavy Metal Ions as Contaminants, Szeged, Hungary, $24^{\text {th }}$ September, 2012.

6. Szunyogh D., Jancsó A., Gyurcsik B., Thulstrup P.W., Hemmingsen L.: A CueR fehérje fémkötő helyét modellező peptidek kölcsönhatása egy-, és kétértékü átmeneti

fémionokkal

XLIX. Komplex Kémiai Kollokvium, május 26-28. Siófok, 2015. 


\section{Köszönetnyilvánítás}

Szeretnék köszönetet mondani Kiss Tamásnak, az MTA-SZTE Bioszervetlen Kémiai Kutatócsoport vezetőjének, hogy lehetőséget biztosított számomra, hogy a Szervetlen és Analitikai Kémiai Tanszéken, a Bioszervetlen Kémiai Kutatócsoportban doktori munkámat elkészítsem, és amiért az eltelt évek alatt mindvégig bíztatott és segített céljaim elérésében. Valamint szeretnék köszönetet mondani Galbács Gábor tanszékvezetőnek, aki bátorított és jó tanácsokkal látott el disszertációm megírása alatt.

Köszönettel tartozom témavezetőimnek, Jancsó Attilának és Gyurcsik Bélának, a szakmai és emberi támogatásukért; amiért munkámat mindvégig figyelemmel kísérték, bíztattak, és akiknek hasznos tanácsai és segítsége nélkül nem szerezhettem volna jártasságot a bioszervetlen kémia és a koordinációs kémiai vizsgálati módszerek terén.

Hálás vagyok munkatársaimnak, különösképpen Németh Eszter, Dancs Ágnes, Dömötör Orsolya és Matyuska Ferenc kollégáimnak, valamint a Szervetlen és Analitikai Kémiai Tanszék minden jelenlegi és egykori dolgozójának, akik támogatásukkal, türelmükkel és tanácsaikkal segítették munkámat, és mindenekfelett kellemes baráti légkört teremtettek.

Köszönöm Lars Hemmingsennek és Peter Thulstrupnak (University of Copenhagen, Koppenhága, Dánia) hogy laboratóriumukban dolgozhattam, segítségükkel többször is eljuthattam a CERN-be (Európai Nukleáris Kutatási Szervezet) ahol érdekes kísérleteket végezhettem. Köszönöm, hogy doktori éveim alatt emberileg és szakmailag is támogattak. Továbbá köszönöm Flemming H. Larsennek, az egy-, és kétdimenziós NMR-spektroszkópia területén, valamint Niels Johan Christensennek a kvantumkémiai számítások során nyújtott segítségét. Szeretnék köszönetet mondani Monika Stachurának, aki bevezetett a PAC-, és $\beta$-NMR spektroszkópiai módszerek rejtelmeibe.

Köszönet illeti a következő személyeket a külföldi kutatómunkám során nyújtott segítségükért: Morten J. Bjerrum, Erik Larsen, Marianne Jensen, Karl Johnston, Alexander Gottberg, Magdalena Kowalska.

Ezúton köszönöm a MÖB (Magyar Ösztöndíj Bizottság) valamint Campus Hungary szervezeteknek az anyagi támogatást, amely lehetővé tette külföldi (Svájc, Dánia) kutatómunkáim elvégzését.

Köszönetet szeretnék mondani minden barátomnak, akik az elmúlt években mellettem voltak.

Végül, de nem utolsó sorban hálával tartozom szüleimnek, testvéreimnek és páromnak, akik mindvégig támogattak abban, hogy doktori tanulmányaimat sikeresen elvégezzem. 


\section{Függelék}

F1. ábra: A PP peptid pH-függő UV spektrumai, valamint a $\lambda=230 \mathrm{~nm}$-nél ábrázolt A vs. $\mathrm{pH}$ görbe $\left(c_{\mathbf{P P}}=1,0 \times 10^{-4} \mathrm{M}, I=0,1 \mathrm{M} \mathrm{NaClO}_{4}, l=10 \mathrm{~mm}, T=298 \mathrm{~K}\right)$

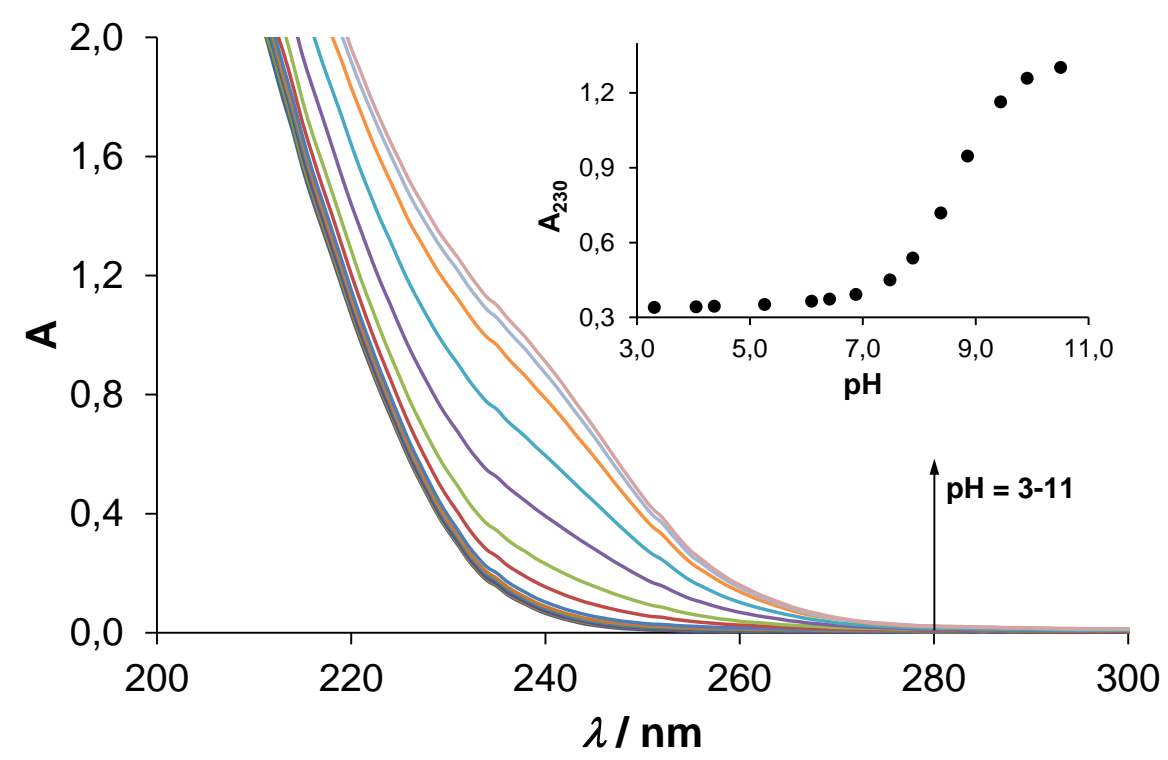

F2. ábra: Az EC peptid pH-függő UV spektrumai, valamint a $\lambda=230 \mathrm{~nm}$-nél ábrázolt $\mathrm{A} v s$. pH görbe $\left(c_{\mathbf{E C}}=1,0 \times 10^{-4} \mathrm{M}, I=0,1 \mathrm{M} \mathrm{NaClO}_{4}, l=10 \mathrm{~mm}, T=298 \mathrm{~K}\right)$

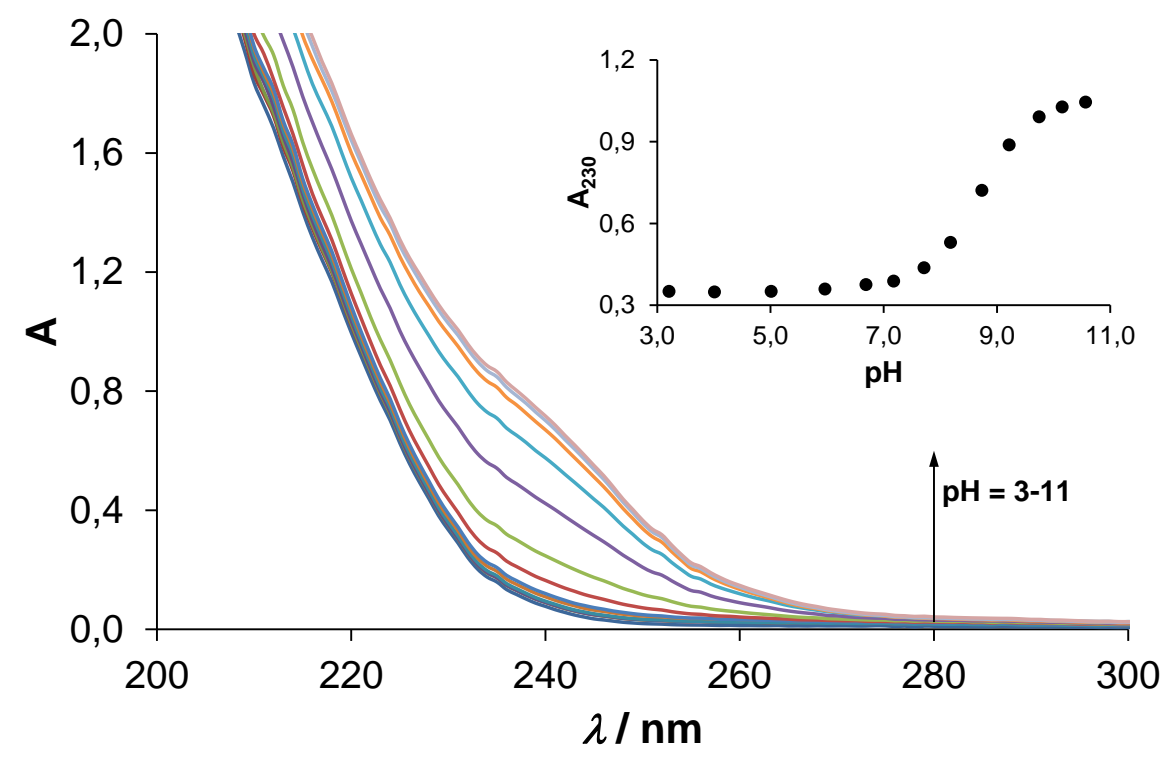


F3. ábra: A PS peptid pH-függő UV spektrumai, valamint a $\lambda=230$ nm-nél ábrázolt $\mathrm{A}$ vs. pH görbe $\left(c_{\mathbf{P S}}=1,0 \times 10^{-4} \mathrm{M}, I=0,1 \mathrm{M} \mathrm{NaClO}_{4}, l=10 \mathrm{~mm}, T=298 \mathrm{~K}\right)$

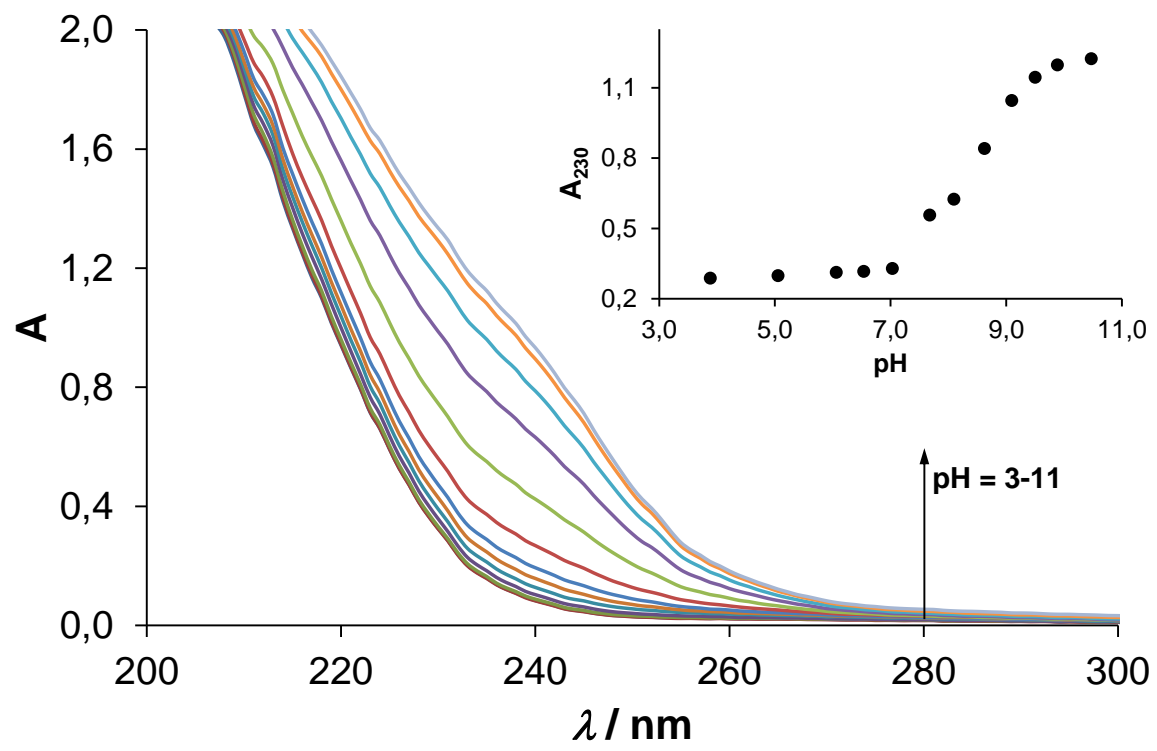

F4. ábra: A HS peptid pH-függö UV spektrumai, valamint a $\lambda=230 \mathrm{~nm}$-nél ábrázolt $\mathrm{A} v s$. pH görbe $\left(c_{\mathbf{H S}}=1,0 \times 10^{-4} \mathrm{M}, I=0,1 \mathrm{M} \mathrm{NaClO}_{4}, l=10 \mathrm{~mm}, T=298 \mathrm{~K}\right)$

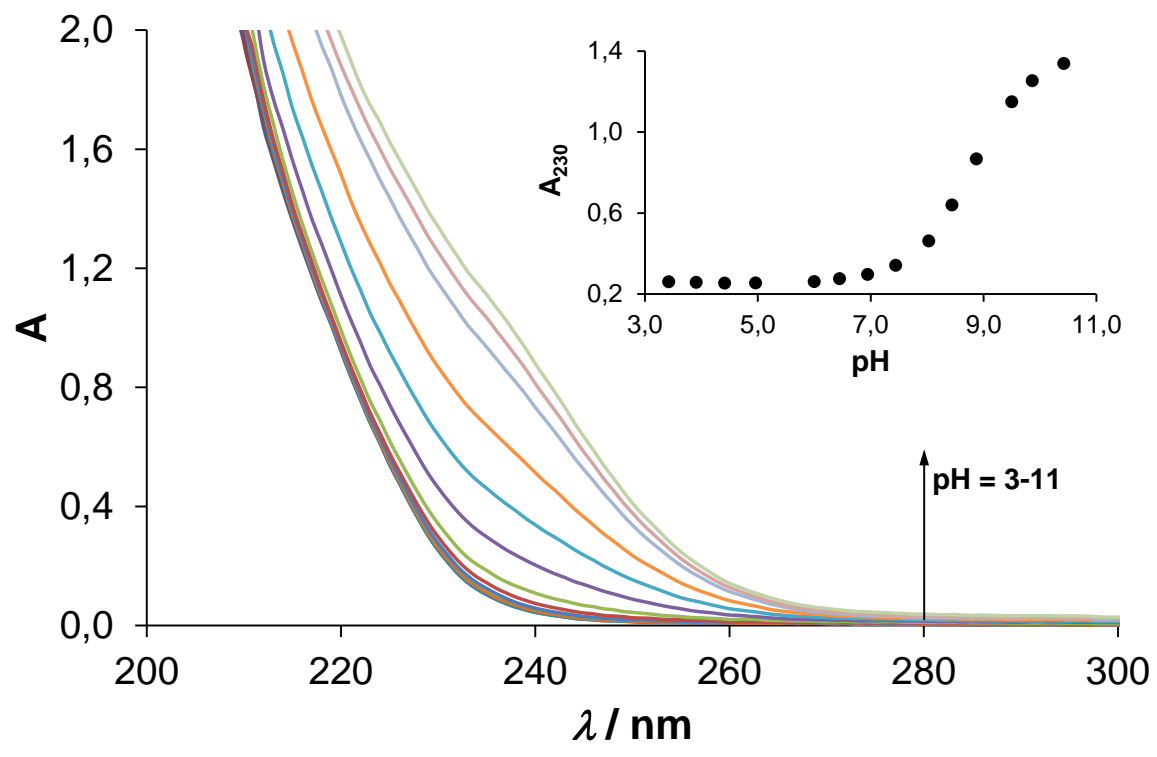


F5. ábra: A szabad PS egydimenziós ${ }^{1} \mathrm{H}$ NMR spektrum csúcsainak azonosítása az alifás hidrogének tartományában $\left(c_{\mathrm{PS}}=3,1 \times 10^{-3} \mathrm{M}, \mathrm{H}_{2} \mathrm{O} / \mathrm{D}_{2} \mathrm{O}=90 / 10 \% \mathrm{v} / \mathrm{v}, I=0,1 \mathrm{M} \mathrm{NaClO}_{4}, \mathrm{pH}=3,73, T=298 \mathrm{~K}\right)$

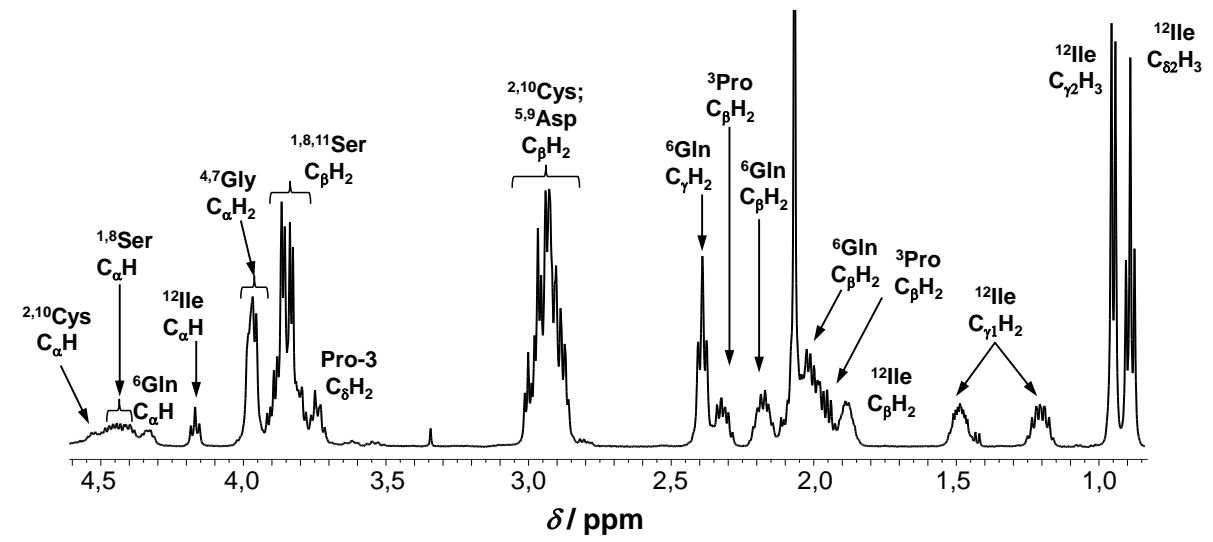

A szabad PS egydimenziós ${ }^{1} \mathrm{H}$ NMR spektrum csúcsainak azonosítása az aromás hidrogének tartományában $\left(c_{\mathbf{P S}}=3,1 \times 10^{-3} \mathrm{M}, \mathrm{H}_{2} \mathrm{O} / \mathrm{D}_{2} \mathrm{O}=90 / 10 \% \mathrm{v} / \mathrm{v}, I=0,1 \mathrm{M} \mathrm{NaClO}_{4}, \mathrm{pH}=3,73, T=298 \mathrm{~K}\right)$

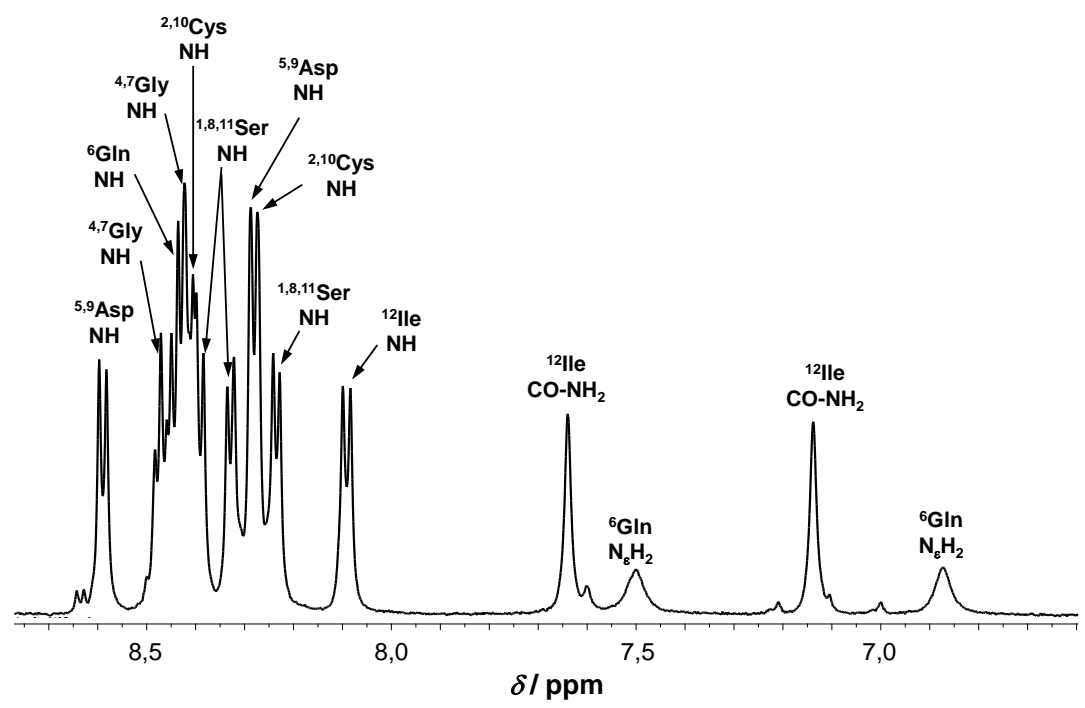

A PS ligandum ${ }^{1} \mathrm{H}$ rezonanciáit jellemző kémiai eltolódás értékek $(\delta / \mathrm{ppm})$ a megfelelő aminosavakhoz rendelve ( $\mathrm{pH}=3,73)$ Ac-Ser-Cys-Pro-Gly-Asp-Gln-Gly-Ser-Asp-Cys-Ser-Ile-NH $\mathrm{N}_{2}$

\begin{tabular}{|c|c|c|c|c|}
\hline Aminosav & NH & $\mathbf{C}_{\alpha} \mathbf{H}$ & $\mathbf{C}_{\beta} \mathbf{H}_{2}$ & Egyéb csoportok \\
\hline${ }^{1,8,11}$ Ser & 8,$22 ; 8,31 ; 8,37$ & $4,43-4,52$ & $3,84-3,94$ & \\
\hline${ }^{2,10}$ Cys & 8,26 és 8,39 & 4,$55 ; \sim 4,85$ & $2,85-3,03$ & \\
\hline${ }^{3}$ Pro & & 4,42 & 1,$98 ; 2,32$ & $\begin{array}{c}\mathrm{C}_{\gamma} \mathrm{H}_{2}: 2,01-2,12 \\
\mathrm{C}_{\delta} \mathrm{H}_{2}: 3,75 ; 3,81\end{array}$ \\
\hline${ }^{4,7}$ Gly & 8,$41 ; 8,45$ & $3,95-4,02$ & & \\
\hline${ }^{5,9}$ Asp & 8,$26 ; 8,57$ & $\sim 4,77 ; \sim 4,78$ & $2,85-3,03$ & \\
\hline${ }^{6}$ Gln & 8,42 & 4,35 & 2,$02 ; 2,18$ & $\begin{array}{c}\mathrm{C}_{\gamma} \mathrm{H}_{2}: 2,39 \\
\mathrm{~N}_{\varepsilon} \mathrm{H}_{2}: 6,86 ; 7,49\end{array}$ \\
\hline${ }^{12}$ Ile & 8,07 & 4,19 & 1,88 & $\begin{array}{c}\mathrm{C}_{\gamma 1} \mathrm{H}_{2}: 1,20 ; 1,47 ; \\
\mathrm{C}_{\gamma 2} \mathrm{H}_{3}: 0,94 ; \mathrm{C}_{\delta} \mathrm{H}_{3}: 0,88 ; \\
\mathrm{CO}-\mathrm{NH}_{2}: 7,12 ; 7,62\end{array}$ \\
\hline $\mathrm{CH}_{3}-\mathrm{CO}$ & & & & 2,06 \\
\hline
\end{tabular}

Gly: $\mathrm{C}_{\alpha} \mathrm{H}_{2} ;$ Ile: $\mathrm{C}_{\beta} \mathrm{H}$ 
F6. ábra: A szabad HS egydimenziós ${ }^{1} \mathrm{H}$ NMR spektrum csúcsainak beazonosítása az alifás hidrogének tartományában $\left(c_{\mathrm{HS}}=3,5 \times 10^{-3} \mathrm{M}, \mathrm{H}_{2} \mathrm{O} / \mathrm{D}_{2} \mathrm{O}=90 / 10 \% \mathrm{v} / \mathrm{v}, I=0,1 \mathrm{M} \mathrm{NaClO}_{4}, \mathrm{pH}=5,37, T=298 \mathrm{~K}\right.$ )

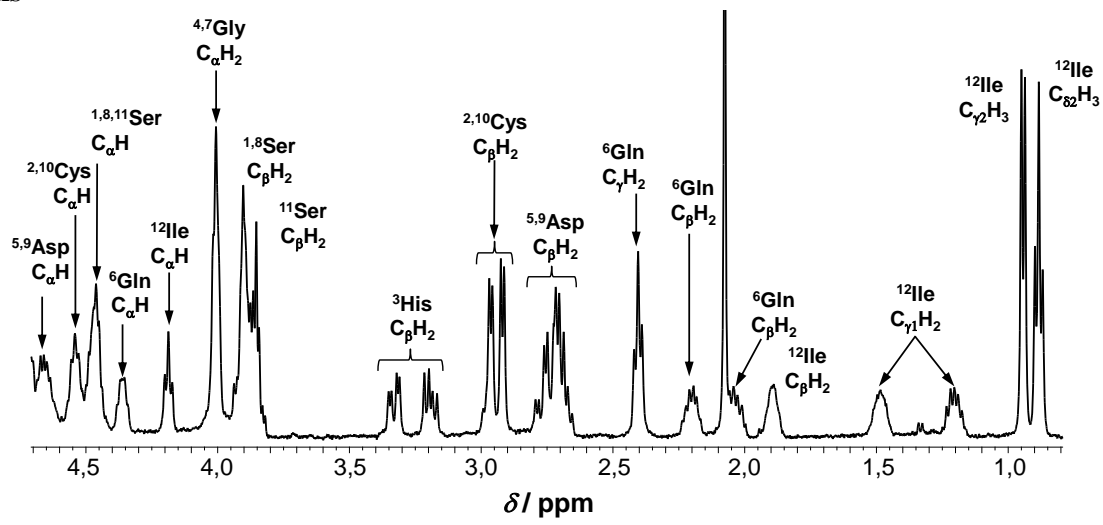

A szabad HS egydimenziós ${ }^{1} \mathrm{H}$ NMR spektrum csúcsainak beazonosítása az aromás hidrogének tartományában $\left(c_{\mathrm{HS}}=3,5 \times 10^{-3} \mathrm{M}, \mathrm{H}_{2} \mathrm{O} / \mathrm{D}_{2} \mathrm{O}=90 / 10 \% \mathrm{v} / \mathrm{v}, I=0,1 \mathrm{M} \mathrm{NaClO}_{4}, \mathrm{pH}=5,37, T=298 \mathrm{~K}\right)$

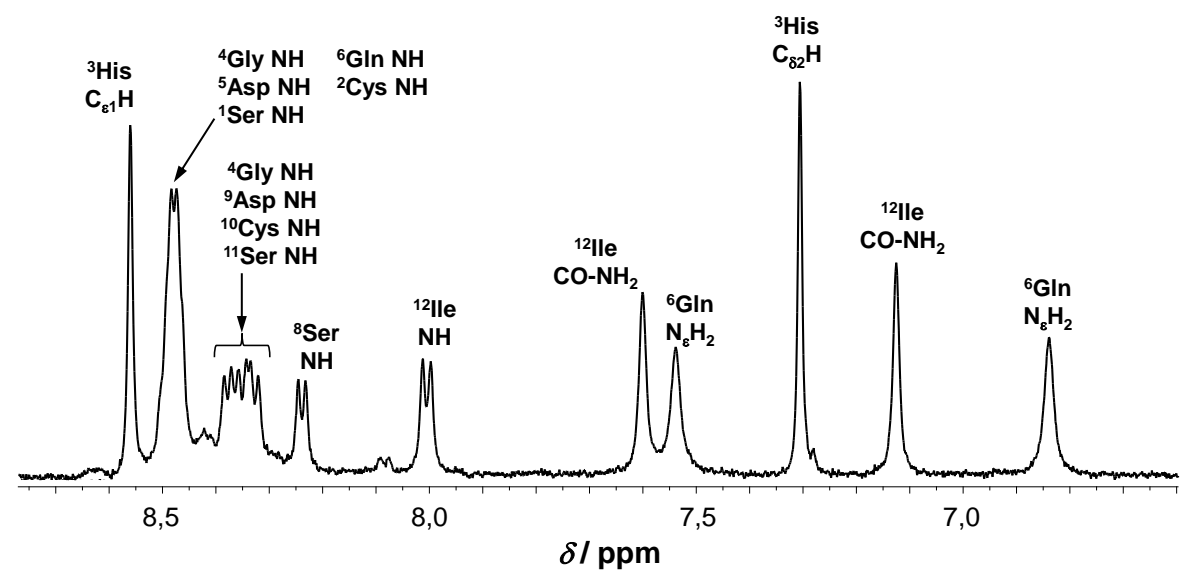

A HS ligandum ${ }^{1} \mathrm{H}$ rezonanciáit jellemzö kémiai eltolódás értékek $(\delta / \mathrm{ppm})$ a megfelelö aminosavakhoz rendelve ( $\mathrm{pH}=5,37)$ Ac-Ser-Cys-His-Gly-Asp-Gln-Gly-Ser-Asp-Cys-Ser-Ile- $\mathrm{NH}_{2}$

\begin{tabular}{|c|c|c|c|c|}
\hline Aminosav & NH & $\mathbf{C}_{\alpha} \mathbf{H}^{\mathbf{a}}$ & $\mathbf{C}_{\beta} \mathbf{H}_{2}$ & Egyéb csoport \\
\hline${ }^{1}$ Ser & 8,34 & \multirow{3}{*}{$4,45-4,52$} & \multirow{3}{*}{$3,83-3,97$} & \multirow{3}{*}{-} \\
\hline${ }^{8}$ Ser & 8,24 & & & \\
\hline${ }^{11}$ Ser & 8,46 & & & \\
\hline${ }^{3} \mathrm{His}$ & & $\sim 4,77$ & 3,$22 ; 3,35$ & $\mathrm{C}_{\varepsilon 1} \mathrm{H}: 8,59 ; \mathrm{C}_{\delta 2} \mathrm{H}: 7,33$ \\
\hline${ }^{2} \mathrm{Cys}$ & 8,46 & \multirow{2}{*}{$4,53-4,59$} & 2,94 & \multirow[t]{2}{*}{ 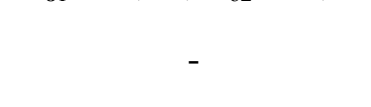 } \\
\hline${ }^{10} \mathrm{Cys}$ & 8,32 & & 2,98 & \\
\hline${ }^{4}$ Gly & 8,41 & \multirow{2}{*}{$4,00-4,06$} & \multirow[b]{2}{*}{-} & \multirow{2}{*}{-} \\
\hline${ }^{7}$ Gly & 8,49 & & & \\
\hline${ }^{5}$ Asp & 8,37 & \multirow{2}{*}{$4,63-4,71$} & \multirow{2}{*}{$2,66-2,83$} & \multirow{2}{*}{ - } \\
\hline${ }^{9}$ Asp & 8,48 & & & \\
\hline \multirow[t]{3}{*}{${ }^{6} \mathbf{G} \ln$} & \multirow[t]{3}{*}{8,47} & \multirow[t]{3}{*}{4,38} & \multirow[t]{2}{*}{2,$06 ; 2,22$} & $\mathrm{C}_{\gamma} \mathrm{H}_{2}: 2,42$ \\
\hline & & & & $\mathrm{N}_{\varepsilon} \mathrm{H}_{2}: 6,85$ és 7,54 \\
\hline & & & \multirow{3}{*}{1,91} & $\mathrm{C}_{\gamma 1} \mathrm{H}_{2}: 1,22$ és 1,50 \\
\hline \multirow[t]{2}{*}{${ }^{12}$ Ile } & \multirow[t]{2}{*}{8,01} & \multirow[t]{2}{*}{4,20} & & $\mathrm{C}_{\gamma 2} \mathrm{H}_{3}: 0,96 ; \mathrm{C}_{\delta} \mathrm{H}_{3}: 0,90$ \\
\hline & & & & $\mathrm{CO}-\mathrm{NH}_{2}:$ 7,13 és7,61 \\
\hline $\mathrm{CH}_{3}-\mathrm{CO}$ & - & - & - & 2,10 \\
\hline
\end{tabular}

Gly: $\mathrm{C}_{\alpha} \mathrm{H}_{2} ;$ Ile: $\mathrm{C}_{\beta} \mathrm{H}$ 
F7. táblázat: A PP ligandum ${ }^{1} \mathrm{H}$ rezonanciáit jellemző kémiai eltolódás értékek $(\delta / \mathrm{ppm})$ a megfelelő aminosavakhoz rendelve $(\mathrm{pH}=4,95)$ Ac-Ser-Cys-Pro-Gly-Asp-Gln-Gly-Ser-Asp-Cys-Ser-Ile- $\mathrm{NH}_{2}$

\begin{tabular}{|c|c|c|c|c|}
\hline Aminosav & NH & $\mathbf{C}_{\alpha} \mathrm{H}$ & $\mathrm{C}_{\beta} \mathrm{H}_{2}$ & Egyéb csoport \\
\hline${ }^{1}$ Ser & 8,35 & \multirow{2}{*}{$4,45-4,51$} & \multirow{2}{*}{$3,81-3,95$} & \multirow[b]{2}{*}{-} \\
\hline${ }^{8}$ Ser & 8,22 & & & \\
\hline${ }^{2} \mathrm{Cys}$ & 8,52 & \multirow{2}{*}{$\sim 4,85$} & \multirow{2}{*}{$2,80-3,01$} & \multirow{2}{*}{-} \\
\hline${ }^{10} \mathrm{Cys}$ & 8,18 & & & \\
\hline \multirow{2}{*}{${ }^{3,11}$ Pro } & \multirow{2}{*}{-} & \multirow{2}{*}{$4,39-4,45$} & $1,89-1,97$ & $\mathrm{C}_{\gamma} \mathrm{H}_{2}: 1,97-2,01$ \\
\hline & & & $2,25-2,36$ & $\mathrm{C}_{\delta} \mathrm{H}_{2}: 3,72-3,81$ \\
\hline${ }^{4}$ Gly & 8,46 & 3,98 & \multirow[b]{2}{*}{-} & \multirow[t]{2}{*}{ 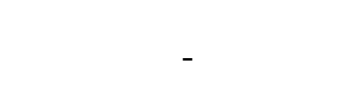 } \\
\hline${ }^{7}$ Gly & 8,48 & 4,01 & & \\
\hline${ }^{5}$ Asp & 8,17 & \multirow{2}{*}{$4,61-4,69$} & \multirow{2}{*}{$2,64-2,79$} & \multirow{2}{*}{-} \\
\hline${ }^{9}$ Asp & 8,49 & & & \\
\hline \multirow{3}{*}{${ }^{6} \mathbf{G l n}$} & \multirow{3}{*}{8,44} & \multirow{3}{*}{4,35} & \multirow{2}{*}{2,03 és 2,21} & $\mathrm{C}_{\gamma} \mathrm{H}_{2}: 2,40$ \\
\hline & & & & $\mathrm{N}_{\varepsilon} \mathrm{H}_{2}: 6,84 ; 7,54$ \\
\hline & & & \multirow{3}{*}{1,85} & $\mathrm{C}_{\gamma 1} \mathrm{H}_{2}: 1,23 ; 1,53$ \\
\hline \multirow[t]{2}{*}{${ }^{12}$ Ile } & \multirow[t]{2}{*}{8,19} & \multirow[t]{2}{*}{4,13} & & $\mathrm{C}_{\gamma 2} \mathrm{H}_{3}: 0,96 ; \mathrm{C}_{\delta} \mathrm{H}_{3}: 0,89$ \\
\hline & & & & $\mathrm{CO}-\mathrm{NH}_{2}: 7,11 ; 7,65$ \\
\hline $\mathrm{CH}_{3}-\mathrm{CO}$ & & & & 2,07 \\
\hline
\end{tabular}

Gly: $\mathrm{C}_{\alpha} \mathrm{H}_{2} ;$ Ile: $\mathrm{C}_{\beta} \mathrm{H}$

F8. ábra: Egy fémiont nem tartalmazó $\mathbf{H S}$ minta időfüggő, $\mathrm{pH}=3,91$-nél mért ${ }^{1} \mathrm{H}$ NMR spektrumának részlete látható (a minta nem volt argon atmoszféra alatt). A Cys $\mathrm{C}_{\beta} \mathrm{H}_{2}$ jelek intenzitása az idő elteltével fokozatosan csökken, ezzel párhuzamosan pedig már 220 perc-nél új jelcsoport megjelenést tapasztaltuk. Az új jelek intenzitása ( $\delta \sim 3,0-3,1 \mathrm{ppm}$ tartomány) az idő elörehaladtával fokozatosan növekszik. Emellett mind az Asp, mind a His $\mathrm{C}_{\beta} \mathrm{H}_{2}$ jelcsoportoknál, valamint az aromás tartományban a His $\mathrm{C}_{\varepsilon 1} \mathrm{H}$ és $\mathrm{C}_{\delta 2} \mathrm{H}$ jelein is tapasztalunk változásokat, ami legfóképpen az említett aminosavak oxidálódó ciszteinekhez való közelségével magyarázható. ( ${ }_{\mathrm{HS}}=1,4 \times 10^{-3} \mathrm{M}, \mathrm{H}_{2} \mathrm{O} / \mathrm{D}_{2} \mathrm{O}=90 / 10 \% \mathrm{v} / \mathrm{v}, I=0,1 \mathrm{M} \mathrm{NaClO}_{4}, \mathrm{pH}=3,91, T=300 \mathrm{~K}$ )

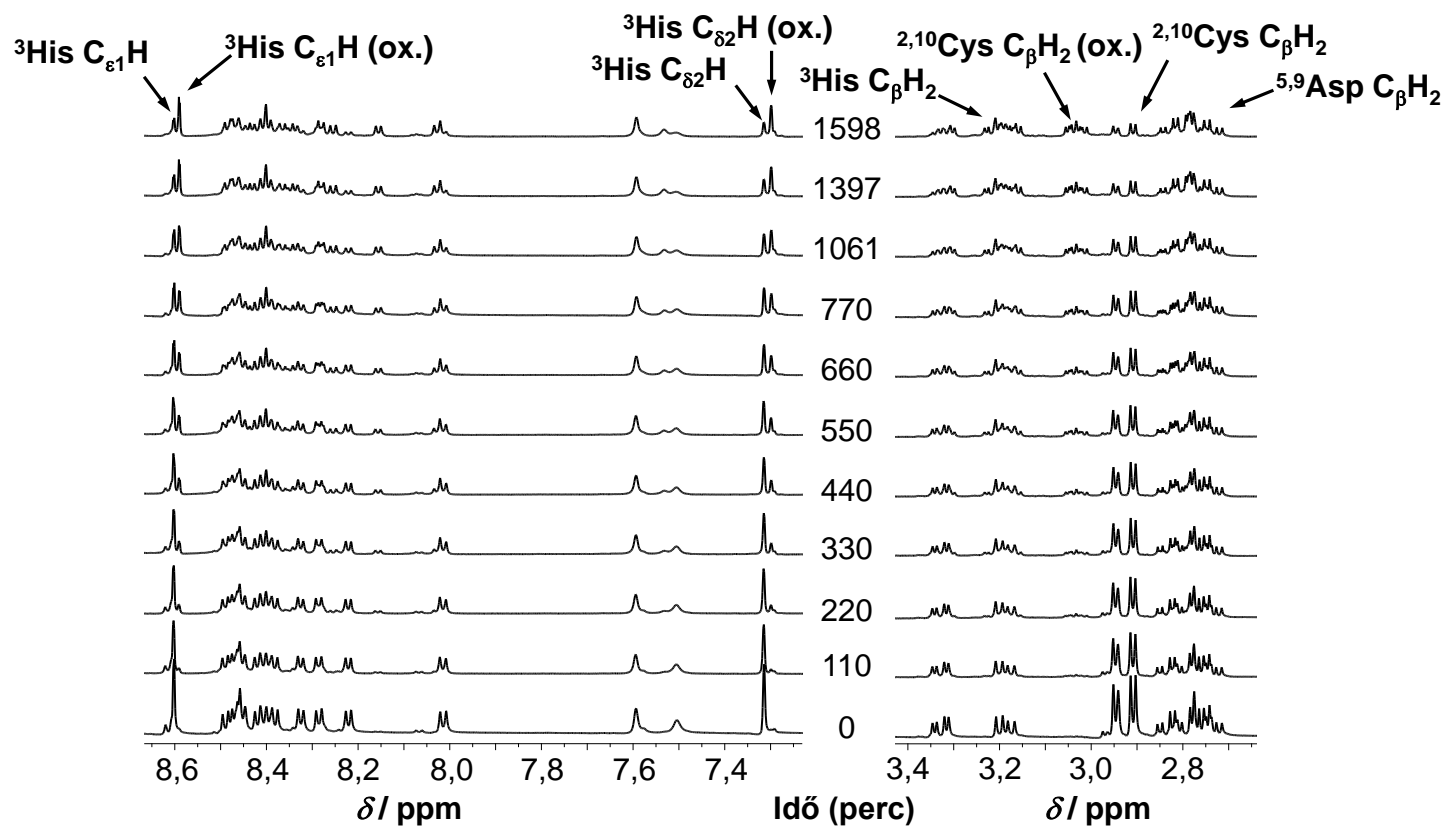


F9. ábra: A szabad PP pH-függő ${ }^{1} \mathrm{H}$ NMR spektrumainak részlete az alifás hidrogének tartományában $\left(c_{\mathbf{P P}}=1,3 \times 10^{-3} \mathrm{M}, \mathrm{H}_{2} \mathrm{O} / \mathrm{D}_{2} \mathrm{O}=90 / 10 \% \mathrm{v} / \mathrm{v}, I=0,1 \mathrm{M} \mathrm{NaClO}_{4}, T=298 \mathrm{~K}\right)$

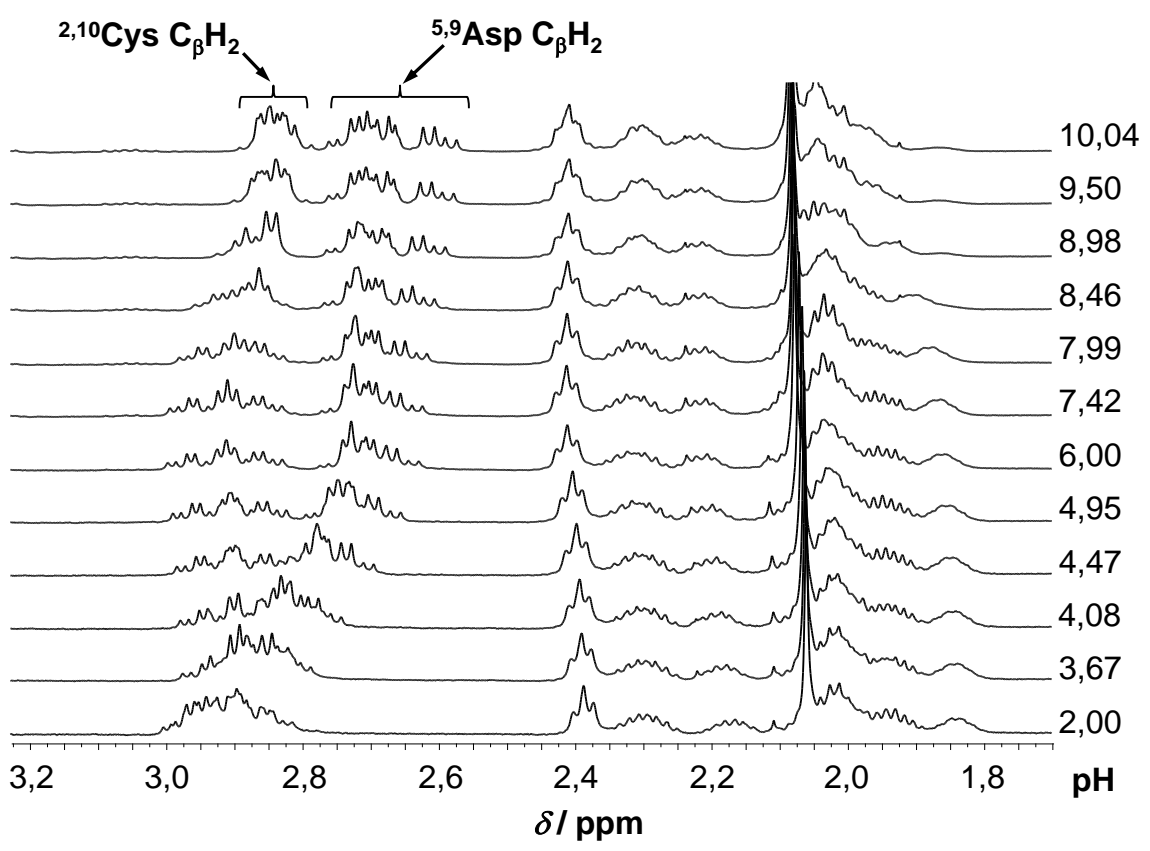

F10. ábra: A szabad $\mathbf{P S} \mathrm{pH}$-függő ${ }^{1} \mathrm{H}$ NMR spektrumainak részlete az alifás hidrogének tartományában $\left(\mathrm{c}_{\mathbf{P S}}=1,3 \times 10^{-3} \mathrm{M}, \mathrm{H}_{2} \mathrm{O} / \mathrm{D}_{2} \mathrm{O}=90 / 10 \% \mathrm{v} / \mathrm{v}, I=0,1 \mathrm{M} \mathrm{NaClO}_{4}, T=298 \mathrm{~K}\right)$

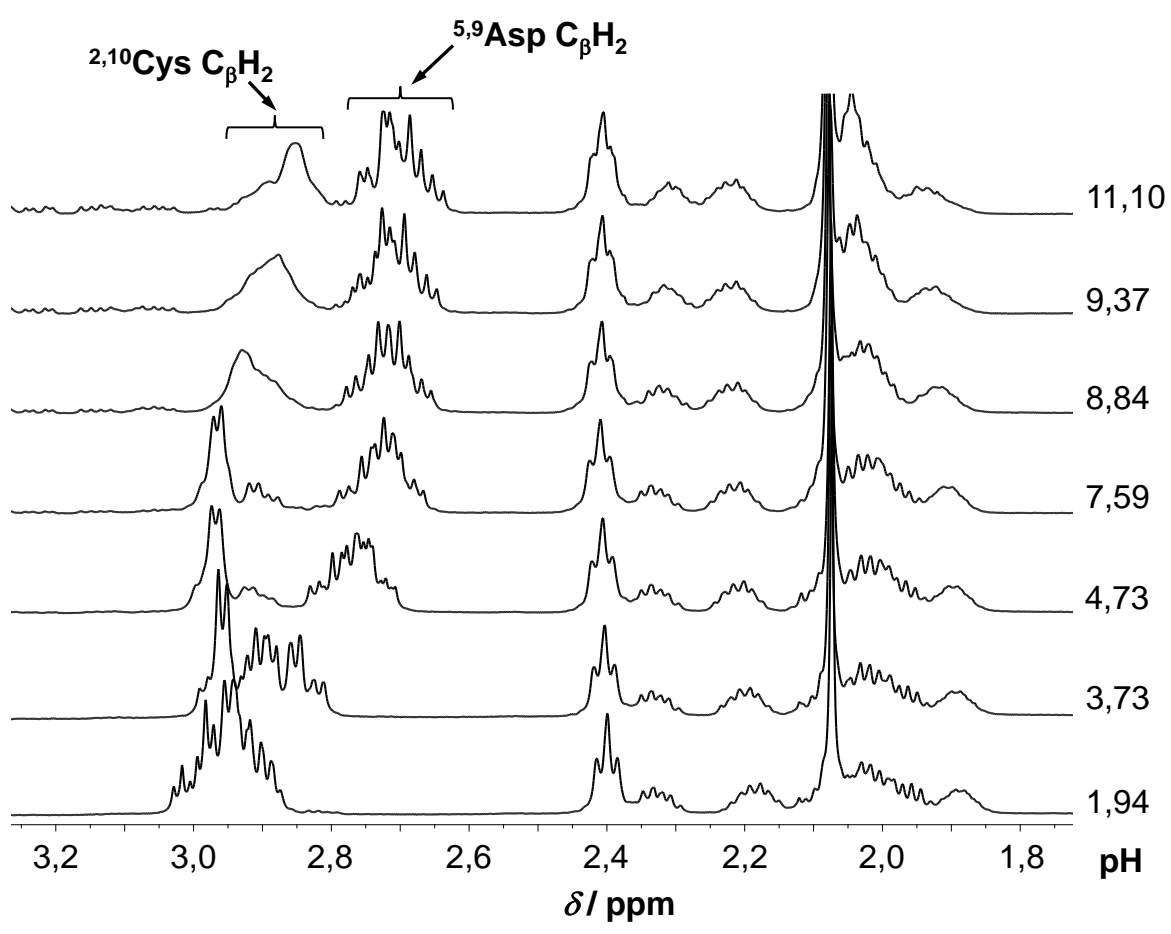


F11. ábra: A szabad $\mathbf{E C} \mathrm{pH}$-függő ${ }^{1} \mathrm{H}$ NMR spektrumainak részlete az alifás hidrogének tartományában $\left(c_{\text {EC }}=1,1 \times 10^{-3} \mathrm{M}, \mathrm{H}_{2} \mathrm{O} / \mathrm{D}_{2} \mathrm{O}=90 / 10 \% \mathrm{v} / \mathrm{v}, I=0,1 \mathrm{M} \mathrm{NaClO}_{4}, T=298 \mathrm{~K}\right)$

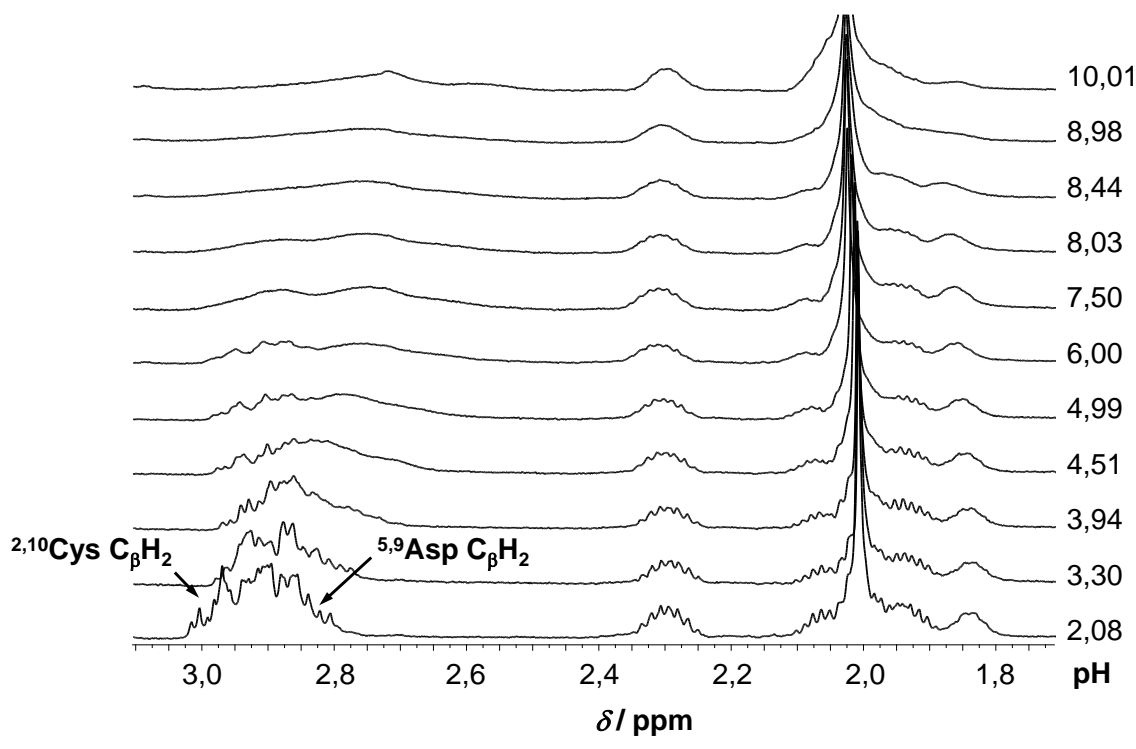

F12. ábra: $\mathrm{A} \mathrm{Zn}^{2+}-\mathbf{P P}$ (bal) és $\mathrm{Cd}^{2+}-\mathbf{P P}$ (jobb) különböző fémion:ligandum arányú rendszerek normált titrálási görbéi $\left(c_{\mathbf{P P}}=1,0 \times 10^{-3} \mathrm{M}, I=0,1 \mathrm{M} \mathrm{NaClO}_{4}, T=298 \mathrm{~K}\right)$
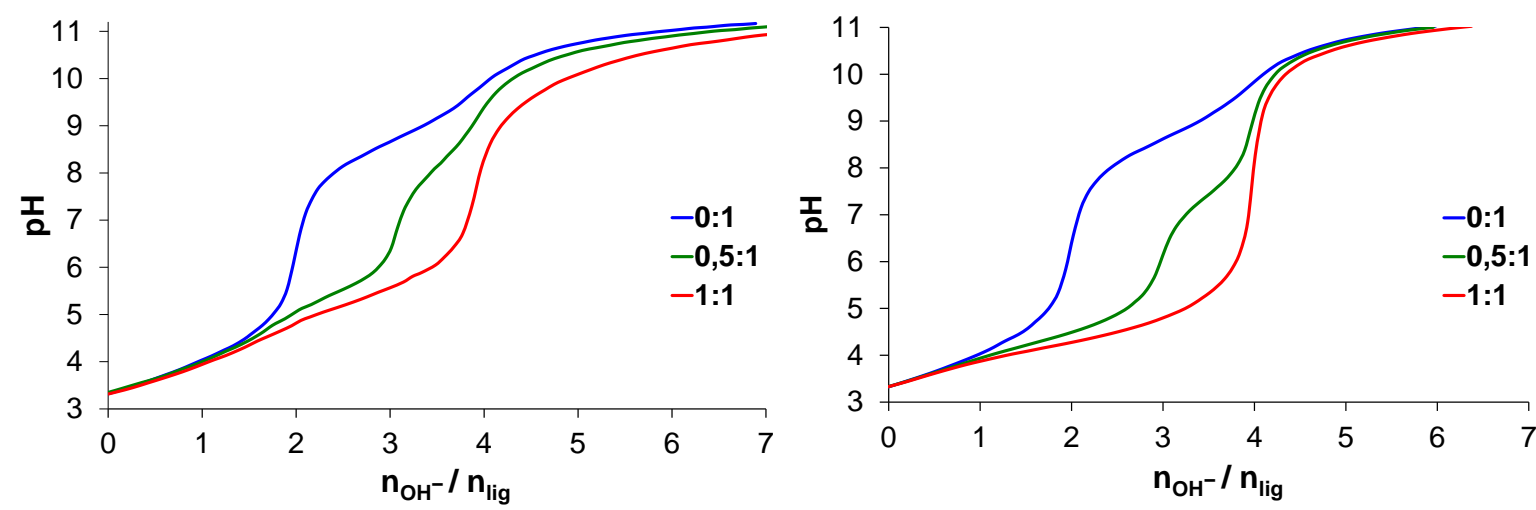

F13. ábra: $\mathrm{A} \mathrm{Zn}^{2+}-\mathbf{H S}$ (bal) és $\mathrm{Cd}^{2+}-\mathbf{H S}$ (jobb) különbözö fémion:ligandum arányú rendszerek normált titrálási görbéi $\left(c_{\mathrm{HS}}=1,0 \times 10^{-3} \mathrm{M}, I=0,1 \mathrm{M} \mathrm{NaClO}_{4}, T=298 \mathrm{~K}\right)$
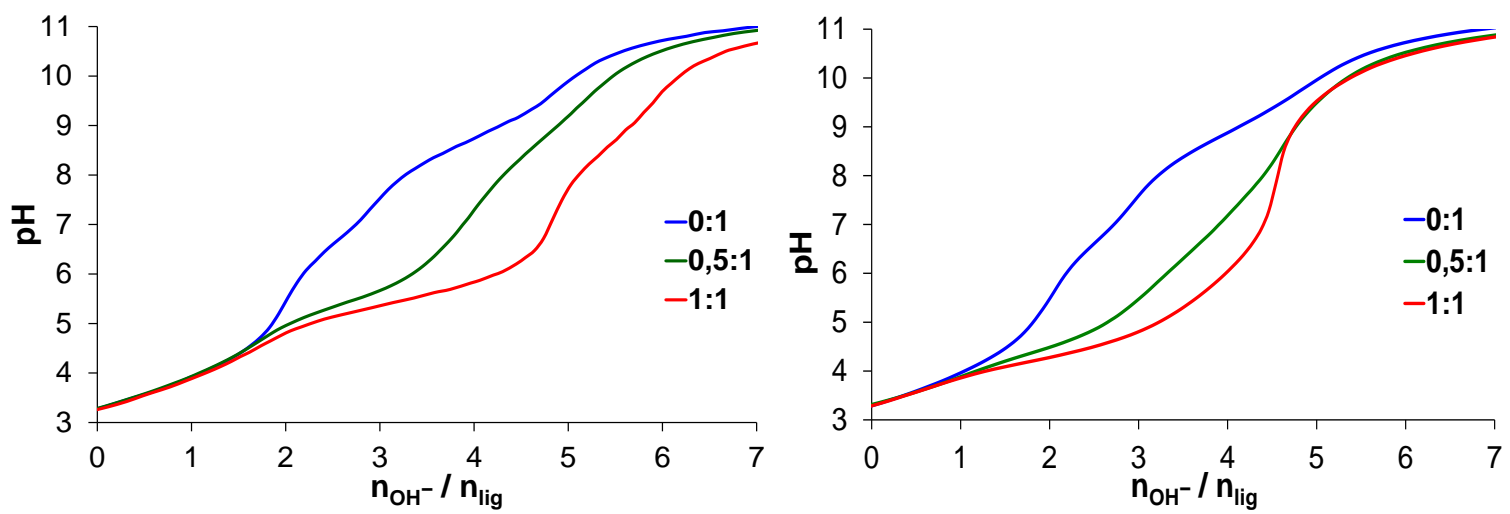
F14. ábra: $\mathrm{Zn}^{2+}$-PP és a $\mathrm{Cd}^{2+}$-PP 1:1 fémion:ligandum arányú rendszerek $\mathrm{A}$ vs. pH görbéi az eloszlási diagramokkal összevetve $\left(c_{\mathbf{P P}}=1,0 \times 10^{-4} \mathrm{M}, I=0,1 \mathrm{M} \mathrm{NaClO}_{4}, l=10 \mathrm{~mm}, T=298 \mathrm{~K}\right)$
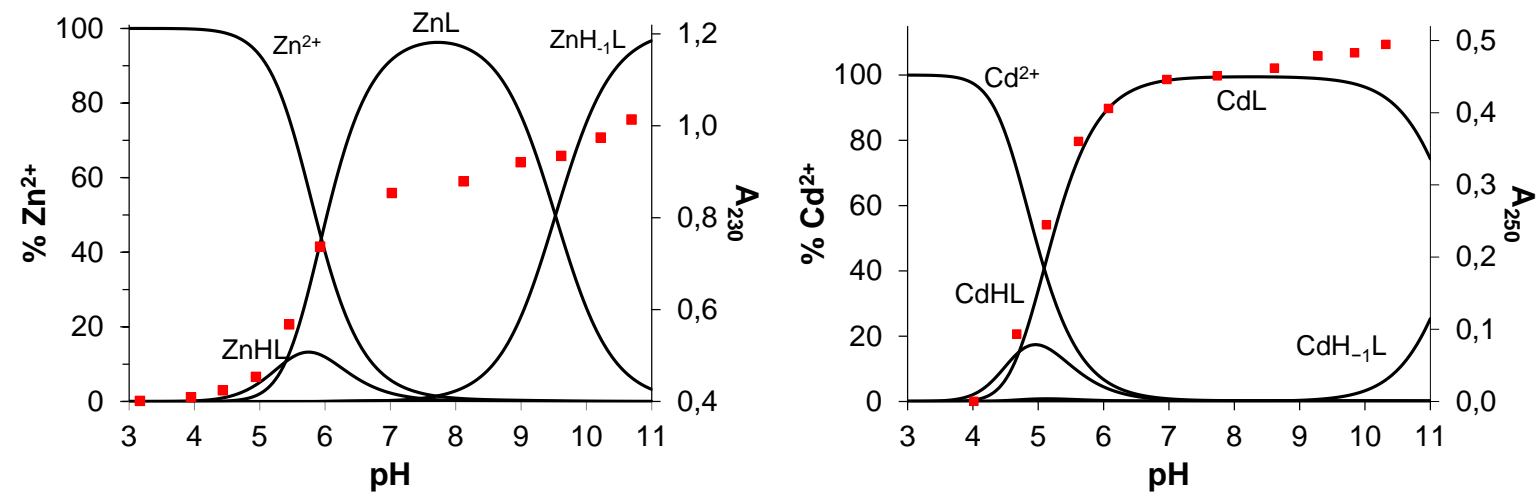

F15. ábra: $\mathrm{Zn}^{2+}$-PS és a $\mathrm{Cd}^{2+}$-PS 1:1 fémion:ligandum arányú rendszerek $\mathrm{A}$ vs. pH görbéi az eloszlási diagramokkal összevetve ( $\left.c_{\mathbf{P S}}=1,0 \times 10^{-4} \mathrm{M}, I=0,1 \mathrm{M} \mathrm{NaClO}_{4}, l=10 \mathrm{~mm}, T=298 \mathrm{~K}\right)$
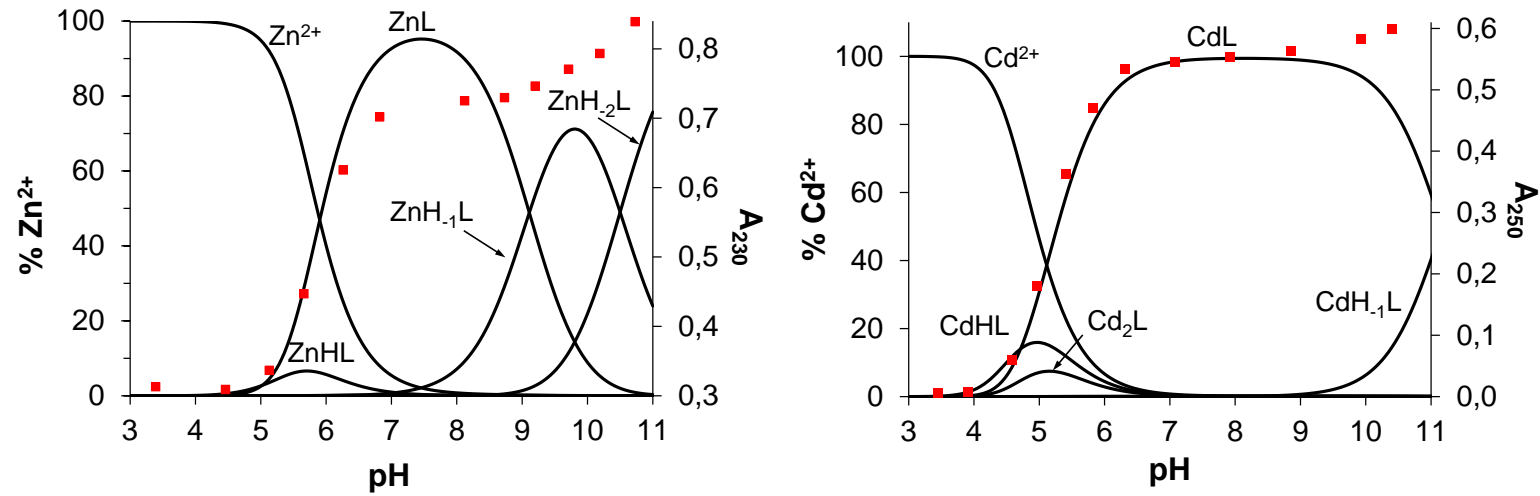

F16. ábra: $\mathrm{Zn}^{2+}$-HS és a $\mathrm{Cd}^{2+}$-HS 1:1 fémion:ligandum arányú rendszerek $\mathrm{A}$ vs. pH görbéi az eloszlási diagramokkal összevetve ( $\left.c_{\text {HS }}=1,0 \times 10^{-4} \mathrm{M}, I=0,1 \mathrm{M} \mathrm{NaClO}_{4}, l=10 \mathrm{~mm}, T=298 \mathrm{~K}\right)$
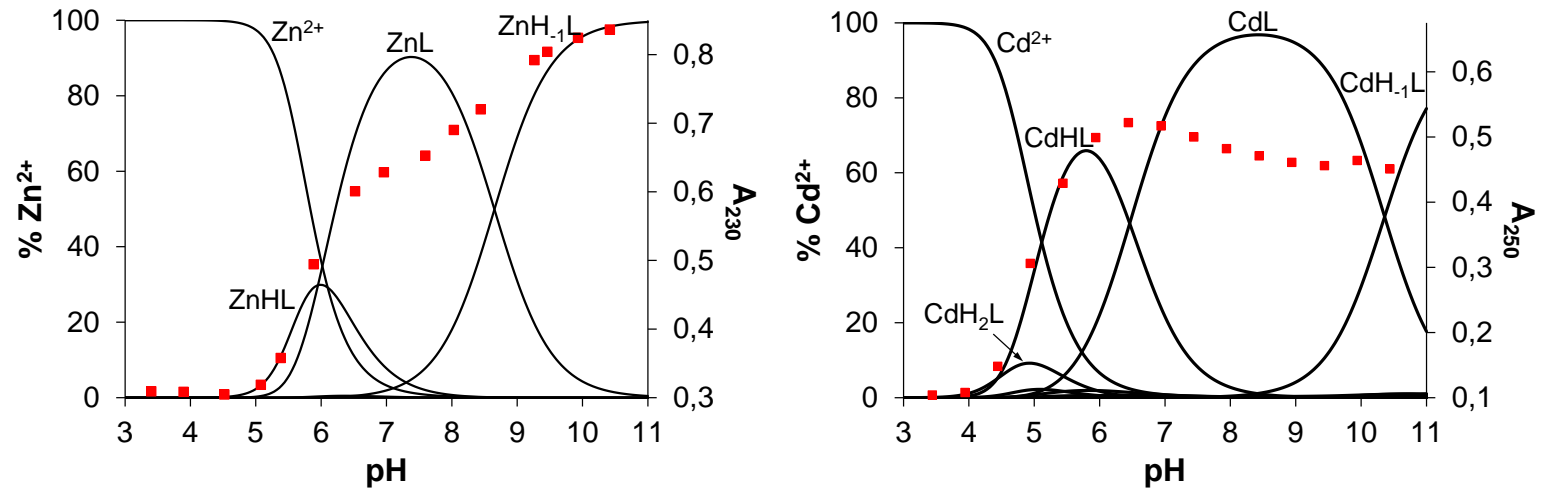
F17. ábra: $\mathrm{Zn}^{2+}-\mathbf{P P}$ (bal) és a $\mathrm{Cd}^{2+}{ }_{-} \mathbf{P P}$ (jobb) 1:1 fémion:ligandum arányú rendszerek pH-függő UV spektrumai $\left(c_{\mathbf{P P}}=1,0 \times 10^{-4} \mathrm{M}, I=0,1 \mathrm{M} \mathrm{NaClO}_{4}, l=10 \mathrm{~mm}, T=298 \mathrm{~K}\right)$
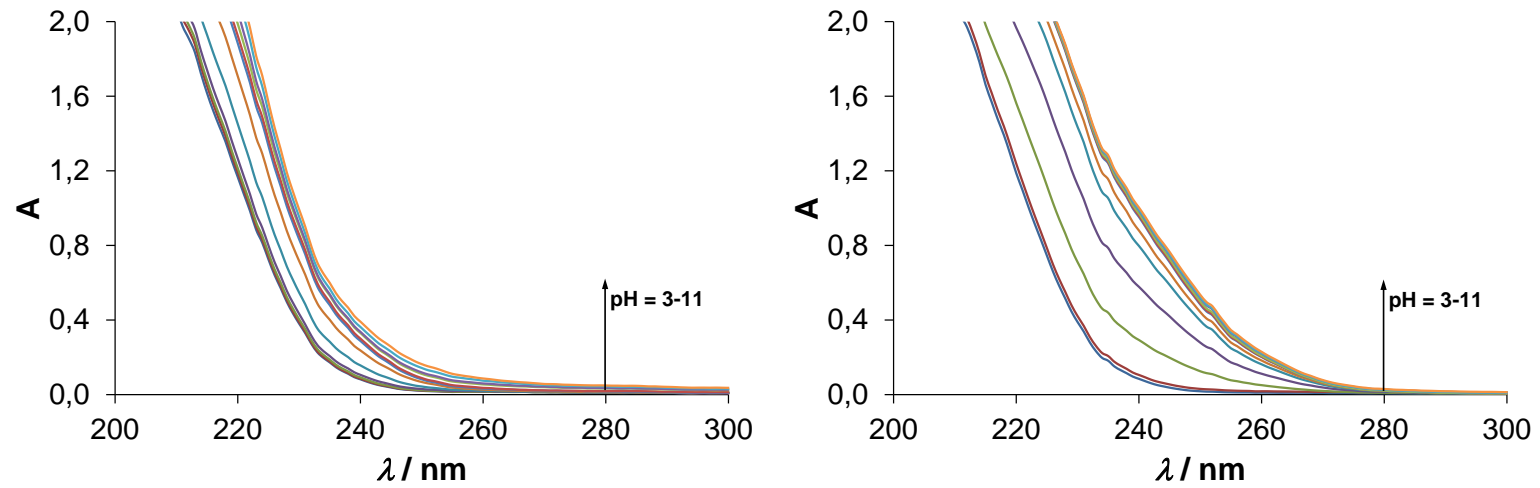

F18. ábra: $\mathrm{Zn}^{2+}-\mathbf{P S}$ (bal) és a $\mathrm{Cd}^{2+}-\mathbf{P S}$ (jobb) 1:1 fémion:ligandum arányú rendszerek pH-függő UV spektrumai $\left(c_{\mathbf{P S}}=1,0 \times 10^{-4} \mathrm{M}, I=0,1 \mathrm{M} \mathrm{NaClO}_{4}, l=10 \mathrm{~mm}, T=298 \mathrm{~K}\right)$
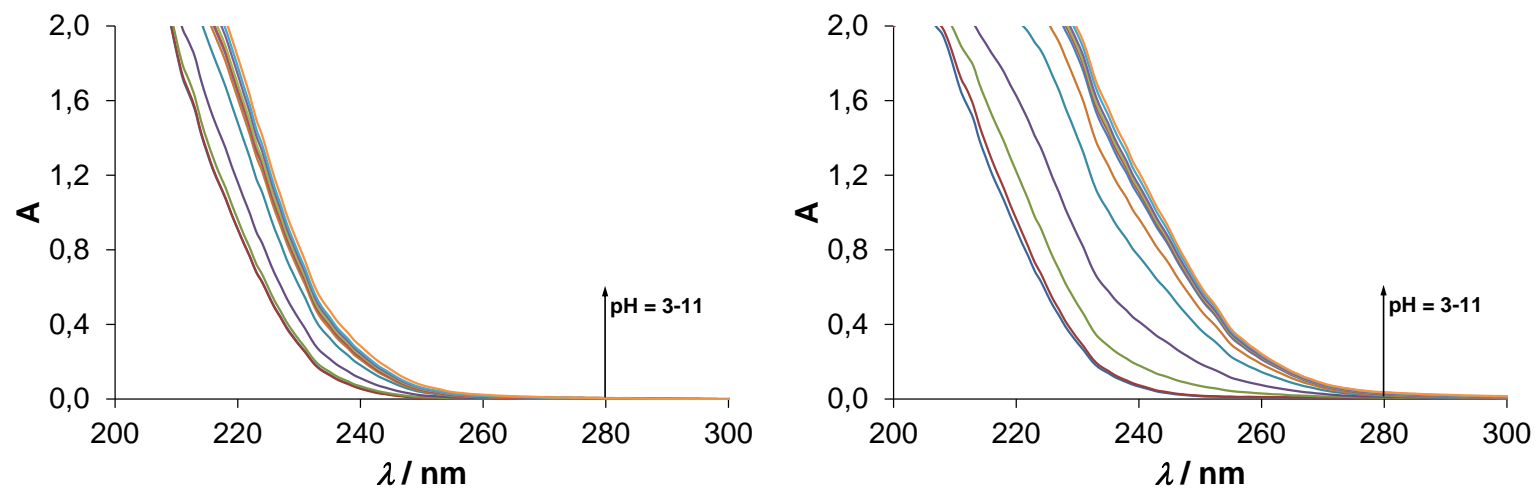

F19. ábra: $\mathrm{Zn}^{2+}-\mathbf{H S}$ (bal) és a $\mathrm{Cd}^{2+}-\mathbf{H S}$ (jobb) 1:1 fémion:ligandum arányú rendszerek pH-függő UV spektrumai $\left(c_{\mathrm{HS}}=1,0 \times 10^{-4} \mathrm{M}, I=0,1 \mathrm{M} \mathrm{NaClO}_{4}, l=10 \mathrm{~mm}, T=298 \mathrm{~K}\right)$
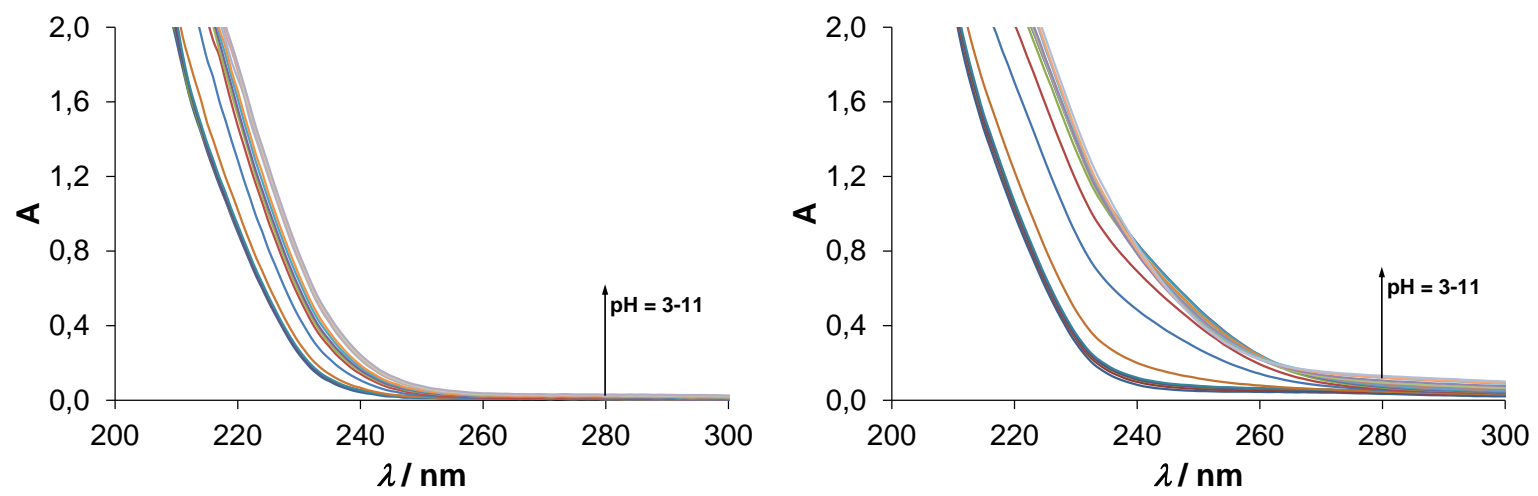
F20. ábra: $\mathrm{Zn}^{2+}$-PP és a $\mathrm{Cd}^{2+}$-PP 0,5:1 fémion:ligandum arányú rendszerek $\mathrm{A}$ vs. pH görbéi az eloszlási diagramokkal összevetve $\left(c_{\mathbf{P P}}=1,0 \times 10^{-4} \mathrm{M}, I=0,1 \mathrm{M} \mathrm{NaClO}_{4}, l=10 \mathrm{~mm}, T=298 \mathrm{~K}\right)$
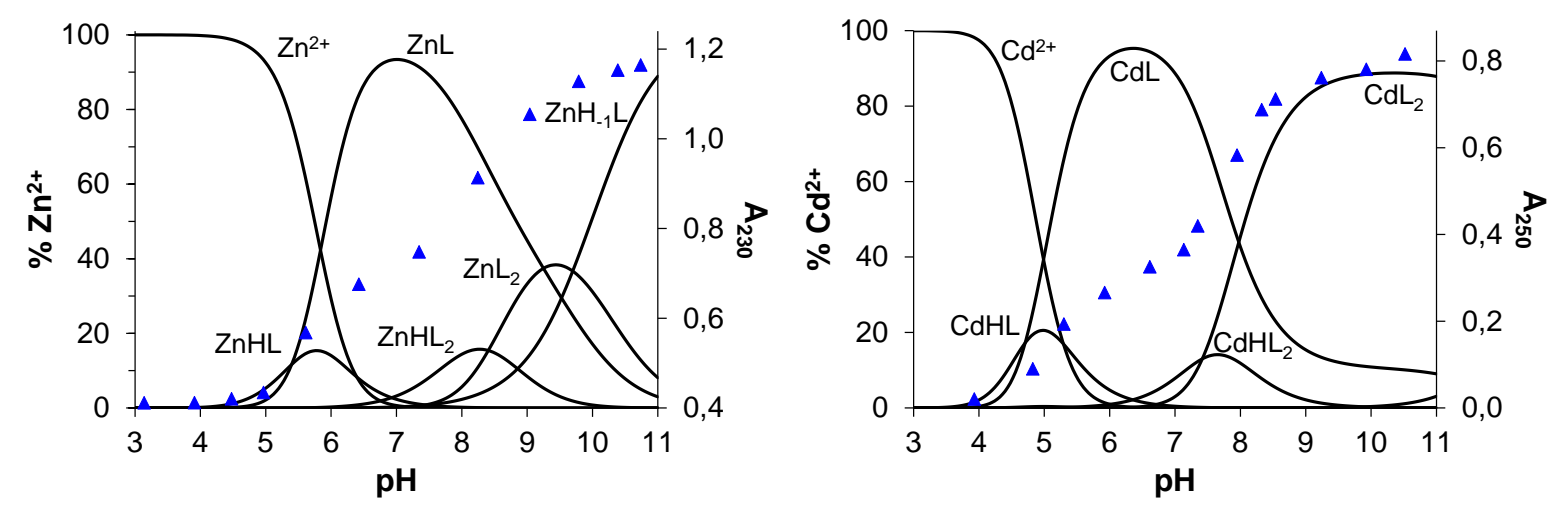

F21. ábra: $\mathrm{Zn}^{2+}$-PS és a $\mathrm{Cd}^{2+}$-PS 0,5:1 fémion:ligandum arányú rendszerek $\mathrm{A}$ vs. pH görbéi az eloszlási diagramokkal összevetve ( $\left.c_{\mathbf{P S}}=1,0 \times 10^{-4} \mathrm{M}, I=0,1 \mathrm{M} \mathrm{NaClO}_{4}, l=10 \mathrm{~mm}, T=298 \mathrm{~K}\right)$
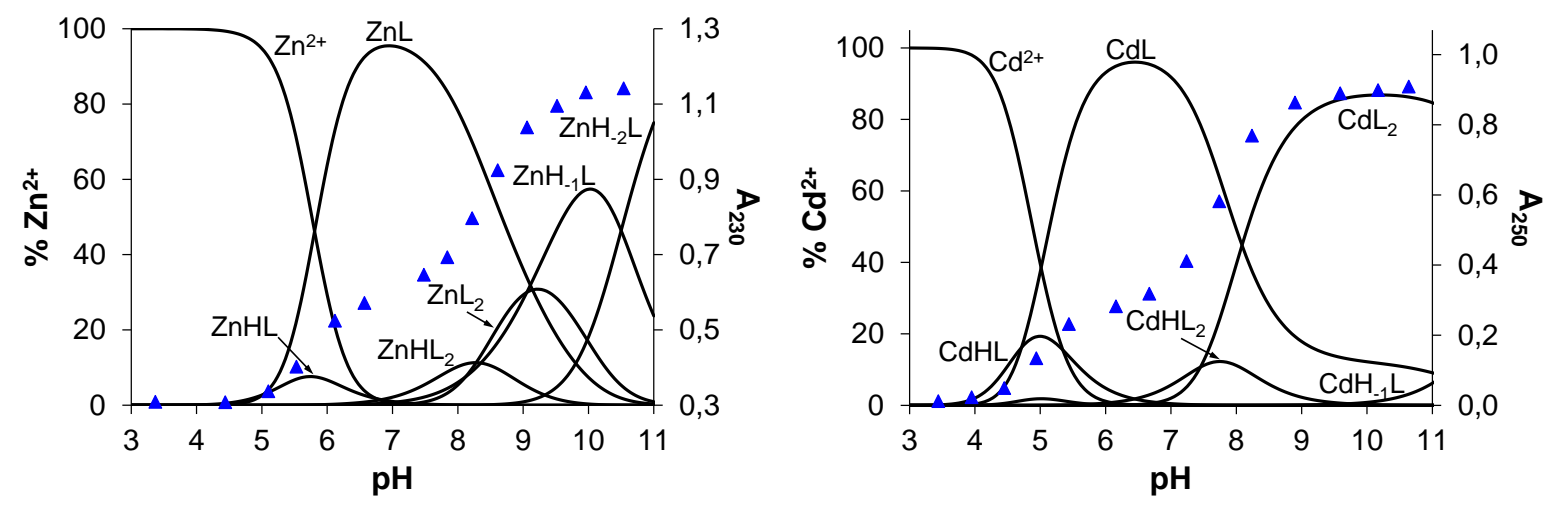

F22. ábra: $\mathrm{Zn}^{2+}$-HS és a $\mathrm{Cd}^{2+}$-HS 0,5:1 fémion:ligandum arányú rendszerek $\mathrm{A} v \boldsymbol{~}$. $\mathrm{pH}$ görbéi az eloszlási diagramokkal összevetve ( $c_{\text {HS }}=1,0 \times 10^{-4} \mathrm{M}, I=0,1 \mathrm{M} \mathrm{NaClO}_{4}, l=10 \mathrm{~mm}, T=298 \mathrm{~K}$ )
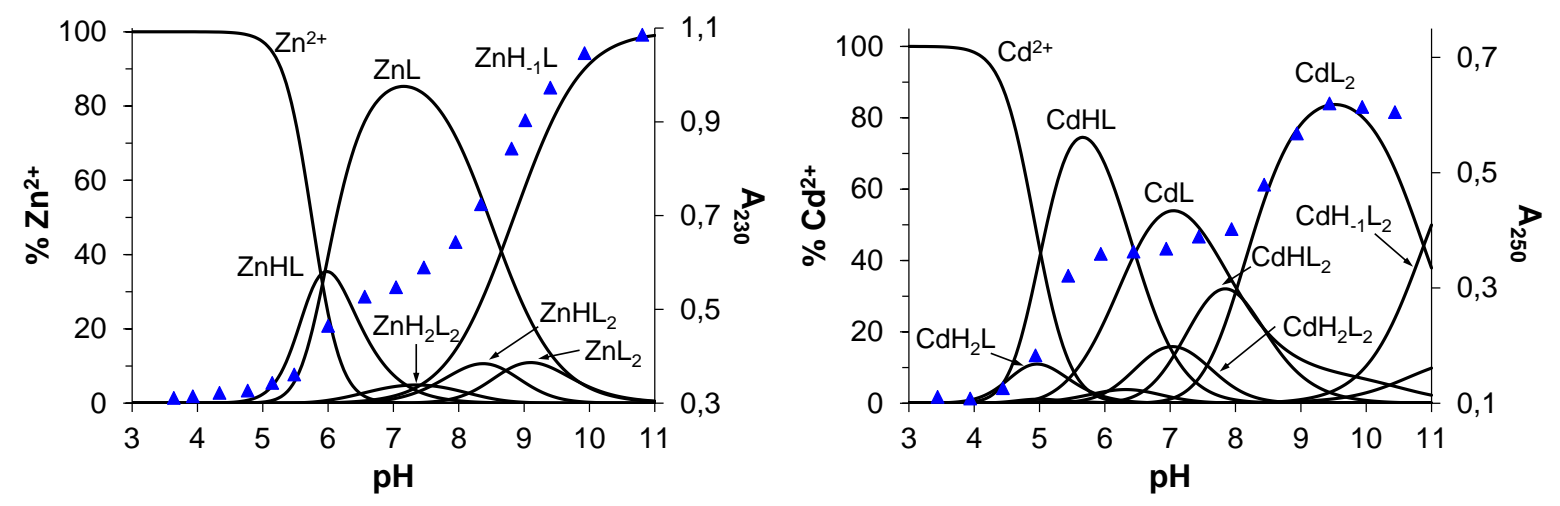
F23. ábra: $\mathrm{Zn}^{2+}-\mathbf{P P}$ (bal) és a $\mathrm{Cd}^{2+}-\mathbf{P P}$ (jobb) 0,5:1 fémion:ligandum arányú rendszerek pH-függő UV spektrumai $\left(c_{\mathbf{P P}}=1,0 \times 10^{-4} \mathrm{M}, I=0,1 \mathrm{M} \mathrm{NaClO}_{4}, l=10 \mathrm{~mm}, T=298 \mathrm{~K}\right)$
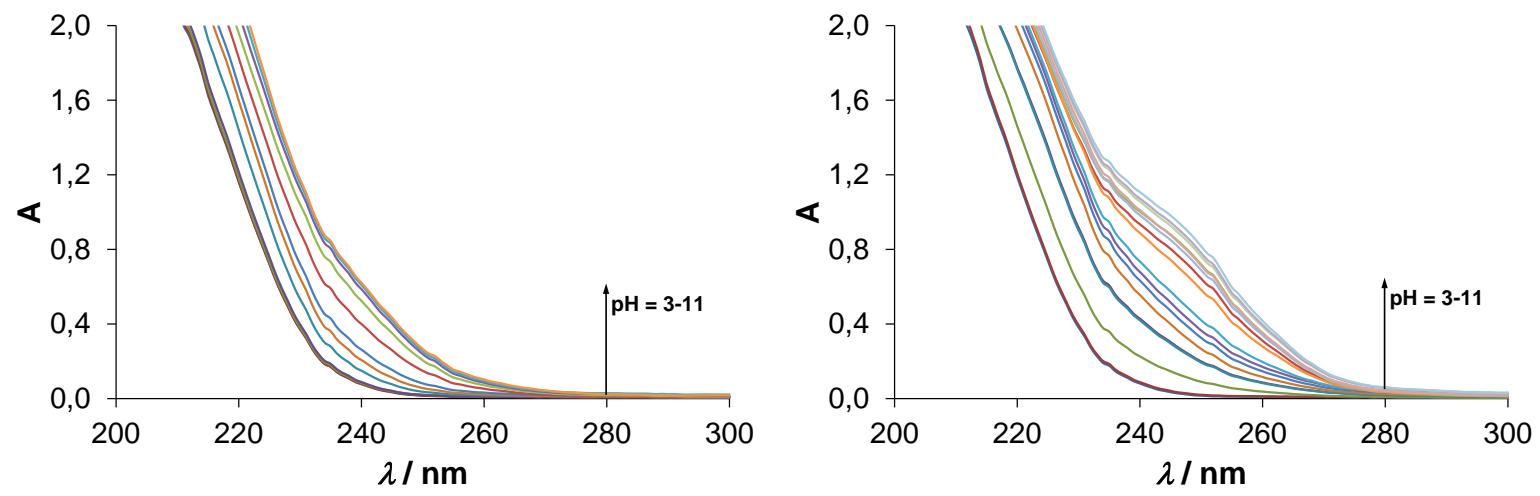

F24. ábra: $\mathrm{Zn}^{2+}$-PS (bal) és a $\mathrm{Cd}^{2+}$-PS (jobb) 0,5:1 fémion:ligandum arányú rendszerek pH-függő UV spektrumai $\left(c_{\mathbf{P S}}=1,0 \times 10^{-4} \mathrm{M}, I=0,1 \mathrm{M} \mathrm{NaClO}_{4}, l=10 \mathrm{~mm}, T=298 \mathrm{~K}\right)$
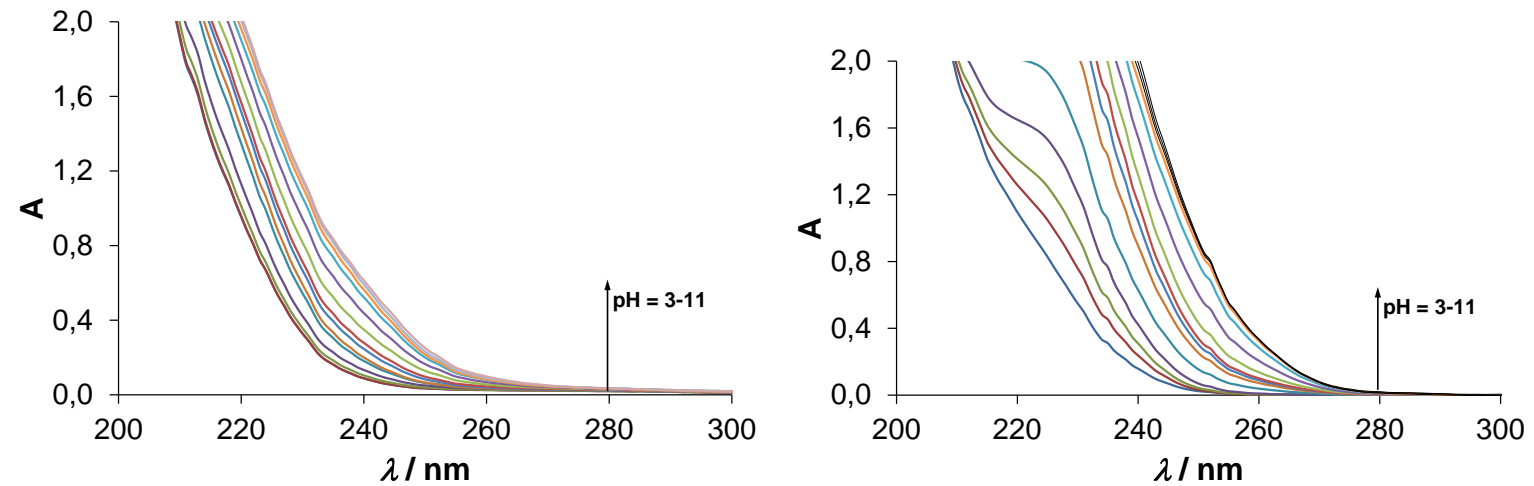

F25. ábra: $\mathrm{Zn}^{2+}-\mathbf{H S}$ (bal) és a $\mathrm{Cd}^{2+}-\mathbf{H S}$ (jobb) 0,5:1 fémion:ligandum arányú rendszerek pH-függő UV spektrumai $\left(c_{\mathrm{HS}}=1,0 \times 10^{-4} \mathrm{M}, I=0,1 \mathrm{M} \mathrm{NaClO}_{4}, l=10 \mathrm{~mm}, T=298 \mathrm{~K}\right)$
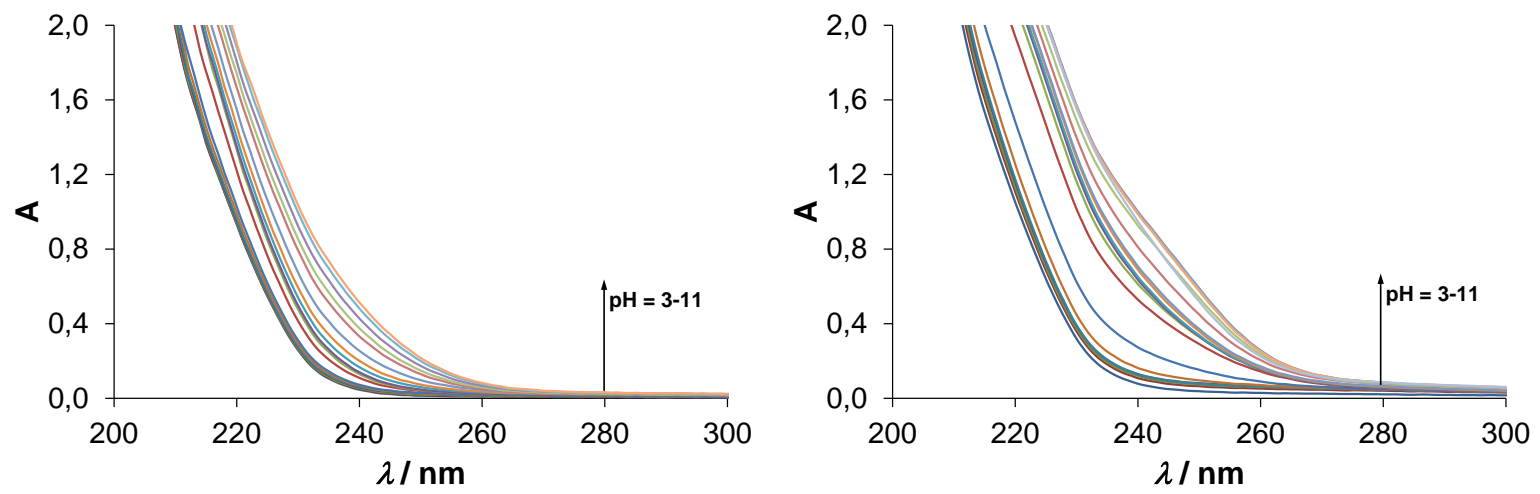
F26. ábra: $\mathrm{Zn}^{2+}$-EC és a $\mathrm{Cd}^{2+}-\mathbf{E C} 1: 1$ fémion:ligandum arányú rendszerek eloszlási diagramjai $\left(c_{\text {EC }}=1,0 \times 10^{-3} \mathrm{M}, I=0,1 \mathrm{M} \mathrm{NaClO}_{4}, T=298 \mathrm{~K}\right)$
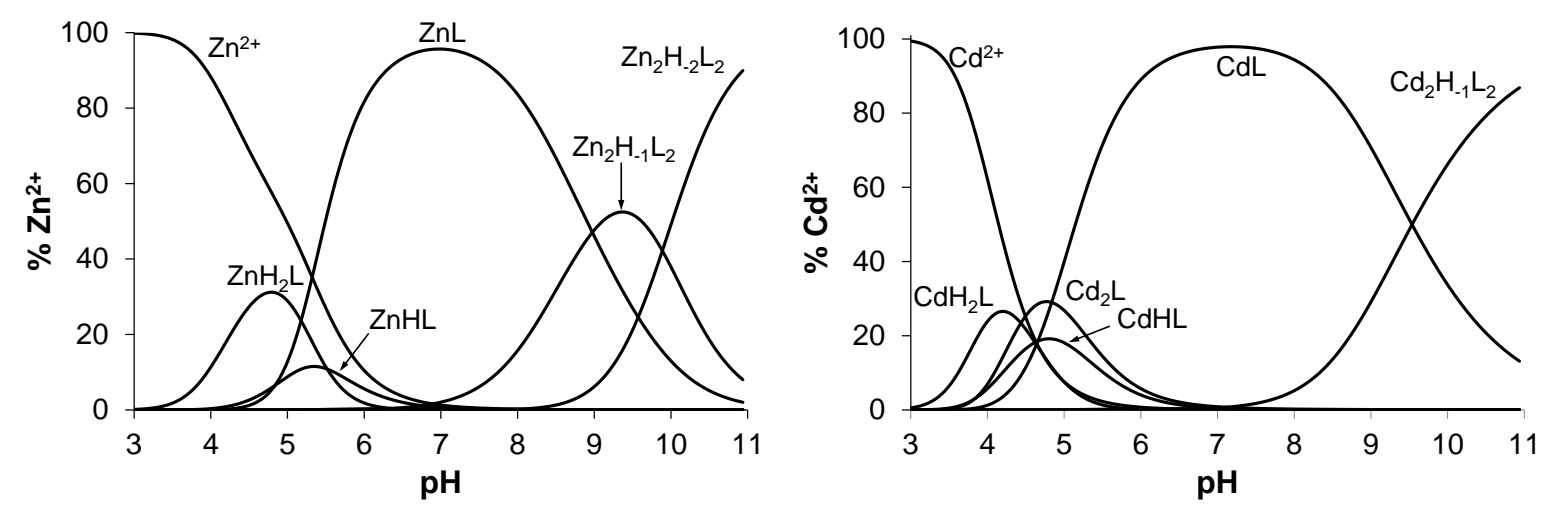

F27. ábra: $\mathrm{Zn}^{2+}$-EC és a $\mathrm{Cd}^{2+}$-EC 1:1 fémion:ligandum arányú rendszerek $\mathrm{A}$ vs. pH görbéi az eloszlási diagramokkal összevetve ( $\left.c_{\mathbf{E C}}=1,0 \times 10^{-4} \mathrm{M}, I=0,1 \mathrm{M} \mathrm{NaClO}_{4}, l=10 \mathrm{~mm}, T=298 \mathrm{~K}\right)$
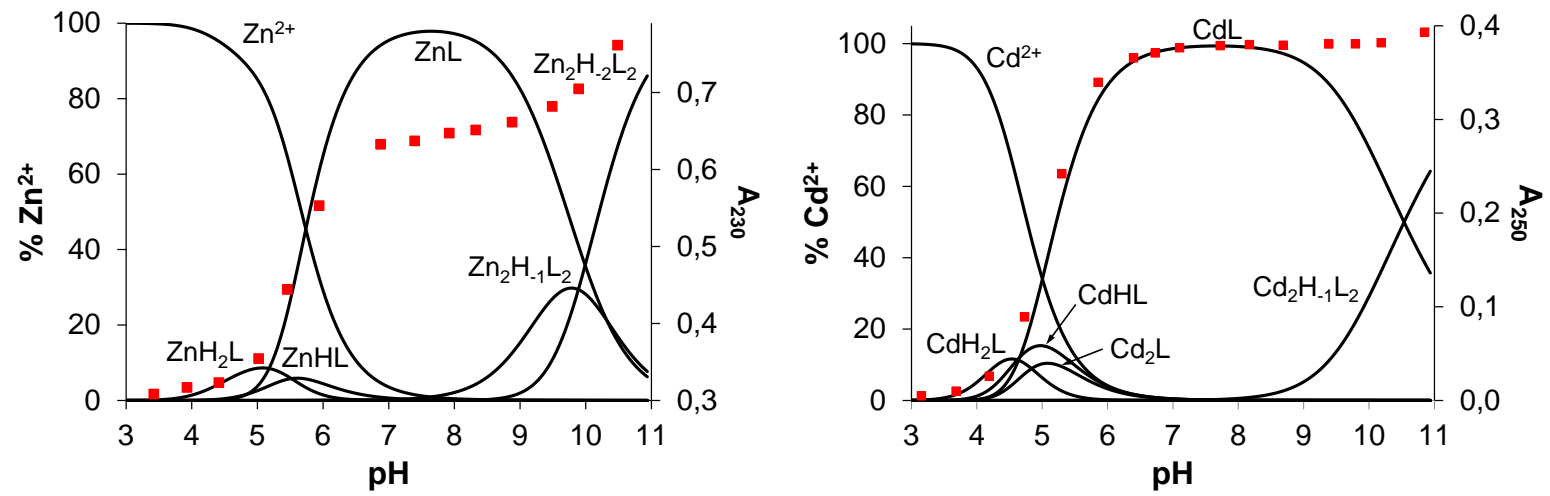

F28. ábra: $\mathrm{Zn}^{2+}-\mathbf{E C}$ (bal) és a $\mathrm{Cd}^{2+}-\mathbf{E C}$ (jobb) 1:1 fémion:ligandum arányú rendszerek pH-függő UV spektrumai ( $\mathrm{c}_{\mathbf{E C}}=1,0 \times 10^{-4} \mathrm{M}, I=0,1 \mathrm{M} \mathrm{NaClO}_{4}, l=10 \mathrm{~mm}, T=298 \mathrm{~K}$ )
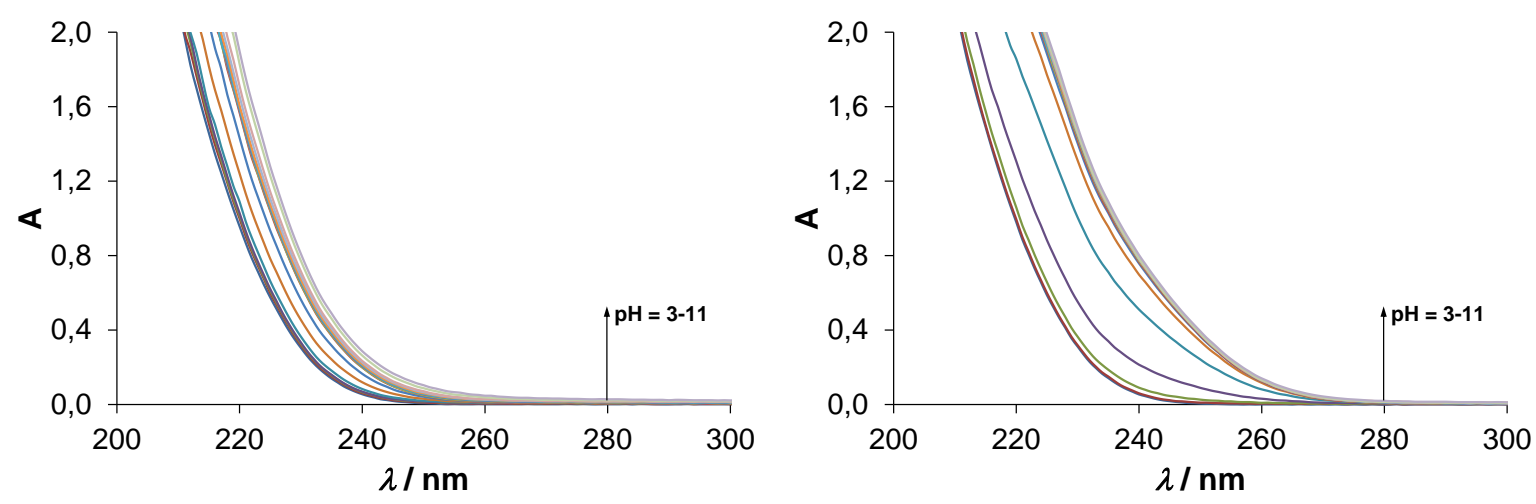
F29. ábra: $\mathrm{Zn}^{2+}-\mathbf{E C}$ és a $\mathrm{Cd}^{2+}-\mathbf{E C} 0,5: 1$ fémion:ligandum arányú rendszerek eloszlási diagramjai $\left(c_{\mathbf{E C}}=1,0 \times 10^{-3} \mathrm{M}, I=0,1 \mathrm{M} \mathrm{NaClO}_{4}, T=298 \mathrm{~K}\right)$
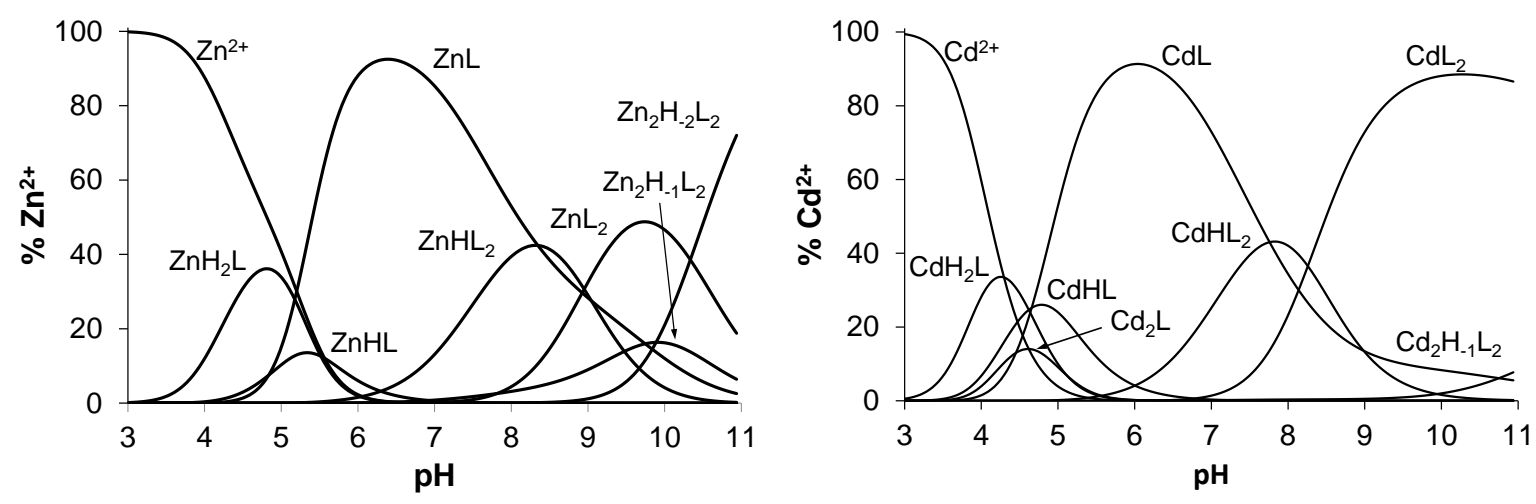

F30. ábra: $\mathrm{Zn}^{2+}-\mathbf{E C}$ és a $\mathrm{Cd}^{2+}-\mathbf{E C}$ 0,5:1 fémion:ligandum arányú rendszerek $\mathrm{A}$ vs. pH görbéi az eloszlási diagramokkal összevetve $\left(c_{\mathbf{E C}}=1,0 \times 10^{-4} \mathrm{M}, I=0,1 \mathrm{M} \mathrm{NaClO}_{4}, l=10 \mathrm{~mm}, T=298 \mathrm{~K}\right)$
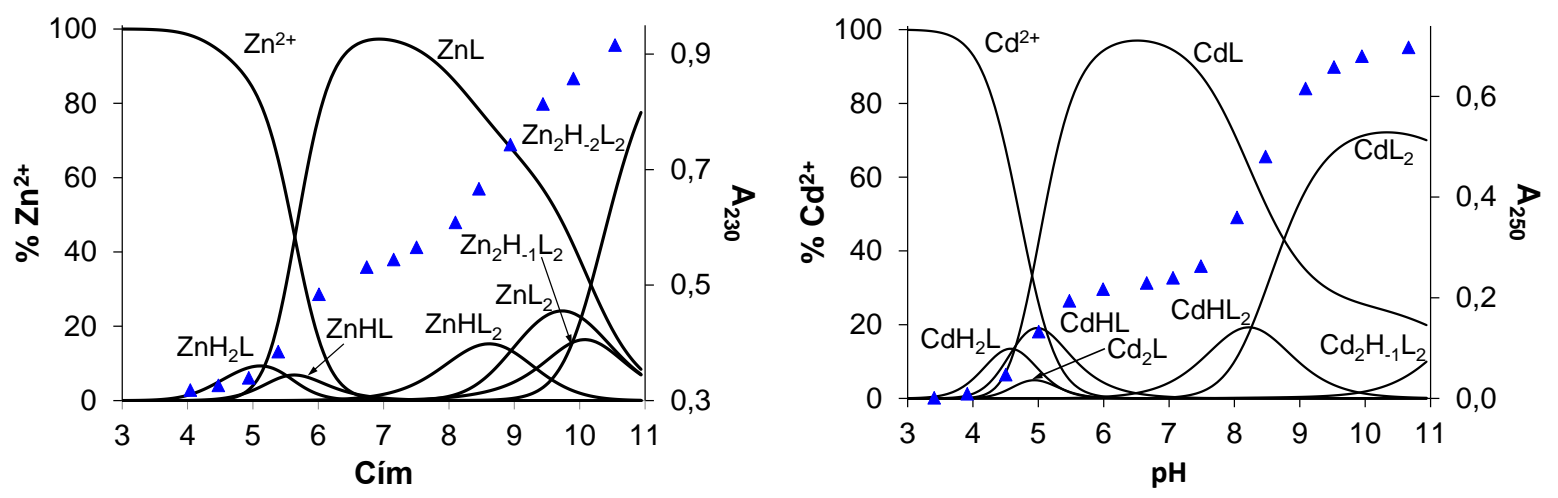

F31. ábra: $\mathrm{Zn}^{2+}-\mathbf{E C}$ (bal) és a $\mathrm{Cd}^{2+}-\mathbf{E C}$ (jobb) 0,5:1 fémion: ligandum arányú rendszerek pH függő $\mathrm{UV}$ spektrumai $\left(c_{\mathbf{E C}}=1,0 \times 10^{-4} \mathrm{M}, I=0,1 \mathrm{M} \mathrm{NaClO}_{4}, l=10 \mathrm{~mm}, T=298 \mathrm{~K}\right)$
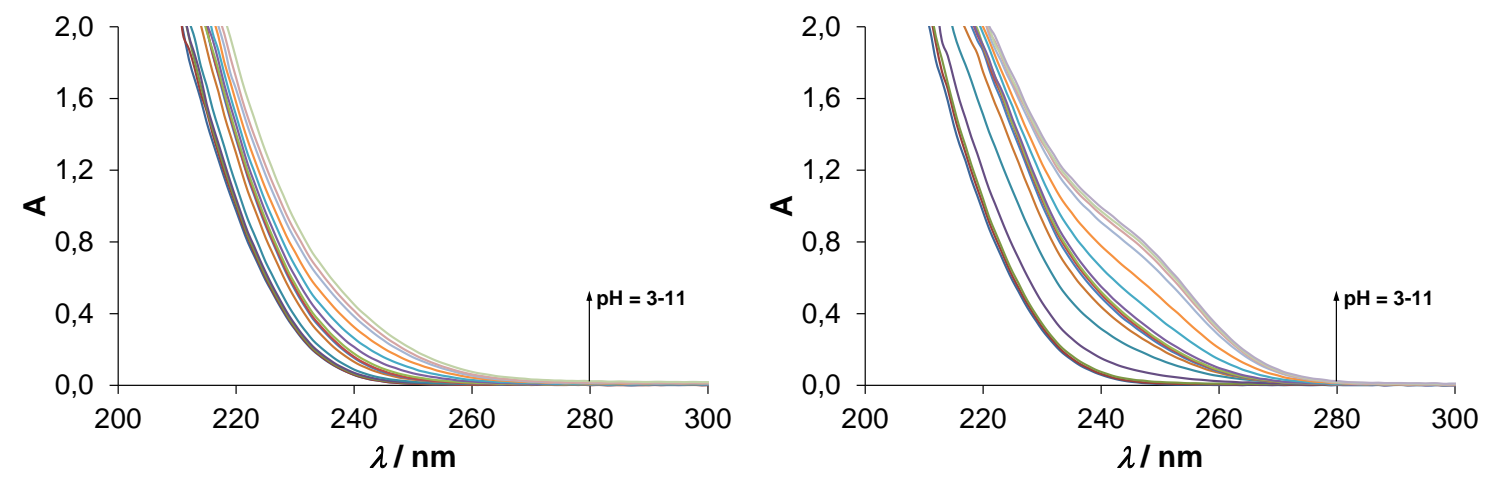
32. ábra: $\mathrm{A} \mathrm{Zn}{ }^{2+}+$ PS 1:1 fémion:ligandum arányú rendszer $\mathrm{pH}$-függö ${ }^{1} \mathrm{H}$ NMR spektrumainak részlete az alifás hidrogének tartományában $\left(c_{\mathbf{P S}}=1,3 \times 10^{-3} \mathrm{M}, \mathrm{H}_{2} \mathrm{O} / \mathrm{D}_{2} \mathrm{O}=90 / 10 \% \mathrm{v} / \mathrm{v}, I=0,1 \mathrm{M} \mathrm{NaClO}_{4}, T=298 \mathrm{~K}\right)$

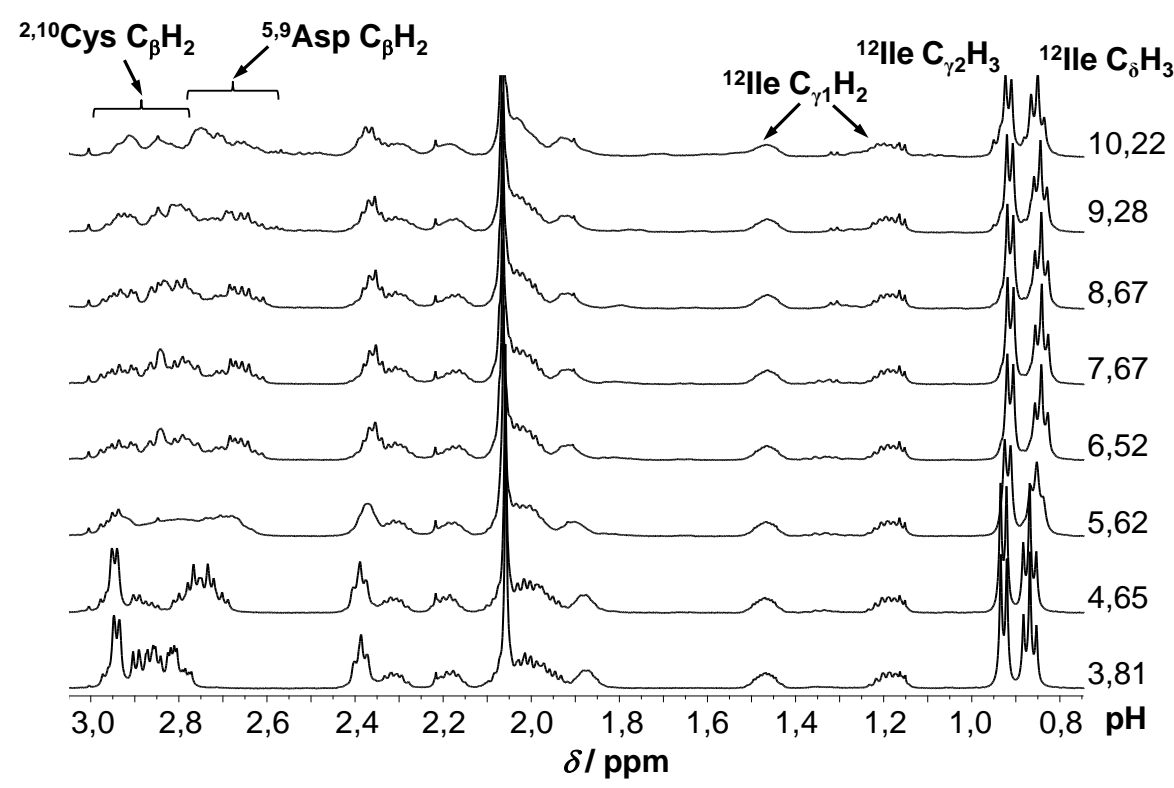

F33. ábra: $\mathrm{A} \mathrm{Cd}^{2+}$-PS 1:1 fémion:ligandum arányú rendszer pH-függő ${ }^{1} \mathrm{H}$ NMR spektrumainak részlete az alifás hidrogének tartományában $\left(c_{\mathbf{P P}}=1,3 \times 10^{-3} \mathrm{M}, \mathrm{H}_{2} \mathrm{O} / \mathrm{D}_{2} \mathrm{O}=90 / 10 \% \mathrm{v} / \mathrm{v}, I=0,1 \mathrm{M} \mathrm{NaClO}_{4}, T=298 \mathrm{~K}\right)$

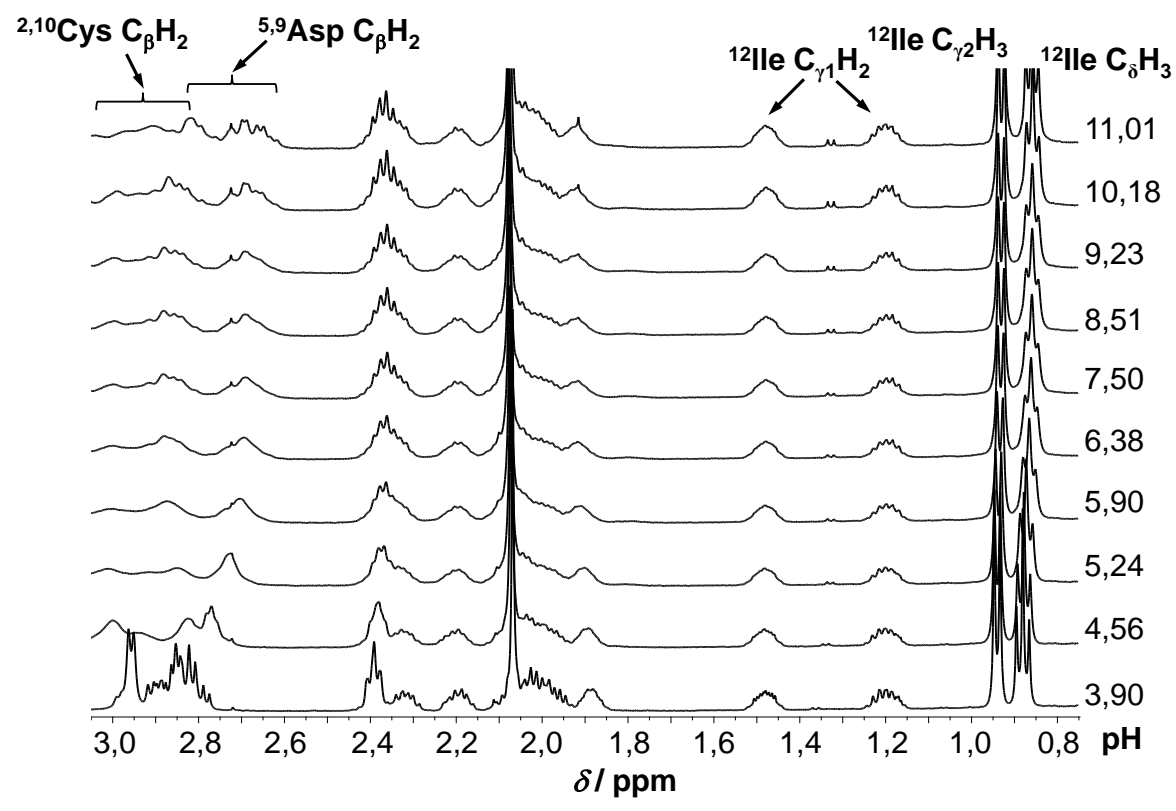


F34. ábra: $\mathrm{A} \mathrm{Zn}^{2+}$-HS rendszerben felvett ${ }^{1} \mathrm{H}$ NMR spektrumok részlete. Kék: szabad $\mathbf{H S}$, Zöld: $\mathrm{Zn}^{2+}-\mathbf{H S}$ 0,5:1, Piros: $\mathrm{Zn}^{2+}-\mathrm{HS} 1: 1\left(c_{\mathrm{HS}}=1,3 \times 10^{-3} \mathrm{M}, \mathrm{H}_{2} \mathrm{O} / \mathrm{D}_{2} \mathrm{O}=90 / 10 \% \mathrm{v} / \mathrm{v}, I=0,1 \mathrm{M} \mathrm{NaClO}_{4}, \mathrm{pH}=5,5, T=298 \mathrm{~K}\right)$

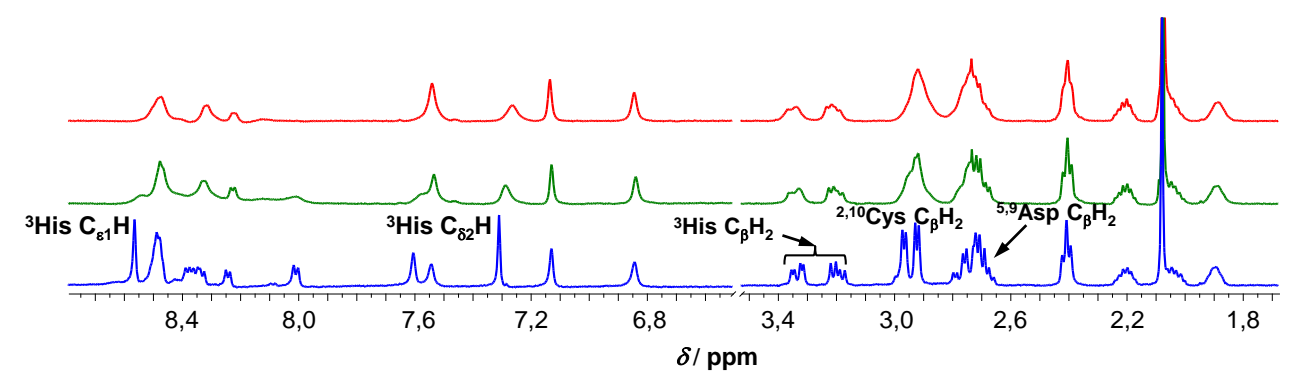

F35. ábra: $\mathrm{A} \mathrm{Cd}^{2+}$-PS 0,5:1 fémion:ligandum arányú $\mathrm{pH}$-függő ${ }^{1} \mathrm{H}$ NMR spektrumainak részlete az alifás hidrogének tartományában $\left(c_{\mathbf{P S}}=1,3 \times 10^{-3} \mathrm{M}, \mathrm{H}_{2} \mathrm{O} / \mathrm{D}_{2} \mathrm{O}=90 / 10 \% \mathrm{v} / \mathrm{v}, I=0,1 \mathrm{M} \mathrm{NaClO}_{4}, T=298 \mathrm{~K}\right.$

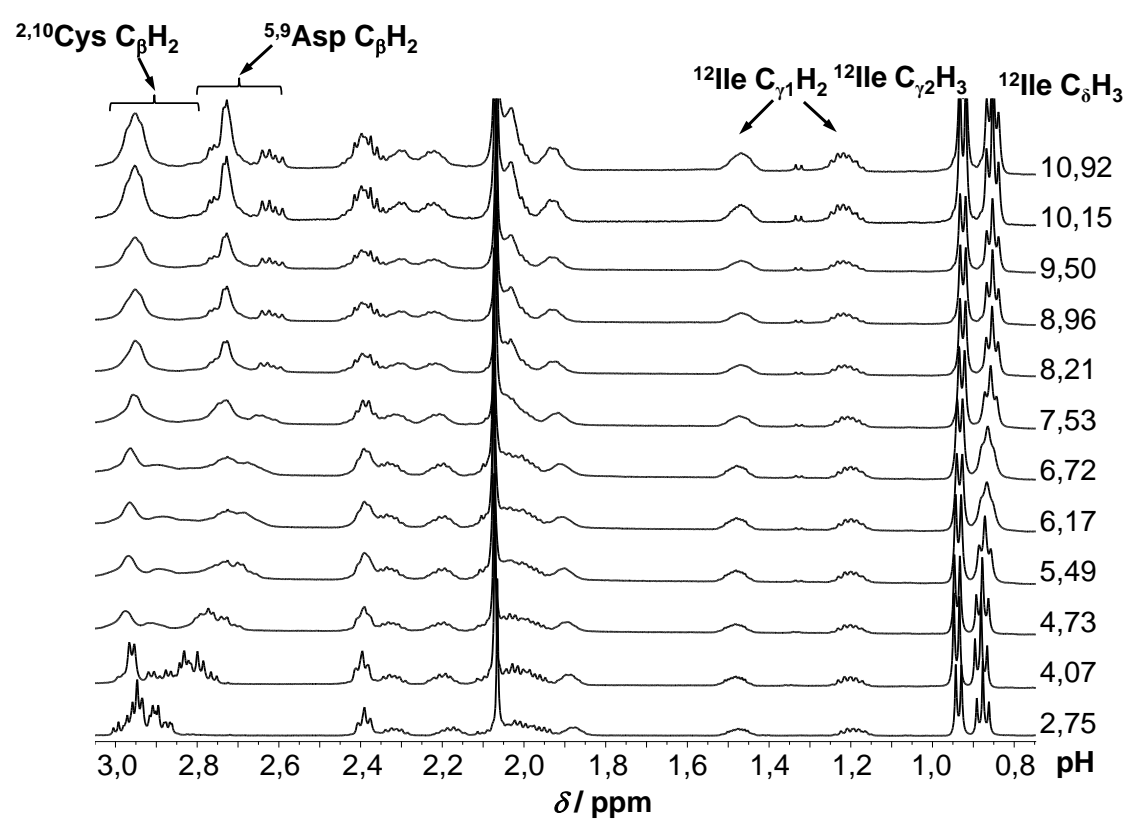

F36. ábra: $\mathrm{A} \mathrm{Zn}^{2+}$-EC 1:1 fémion:ligandum arányú rendszer $\mathrm{pH}$-függő ${ }^{1} \mathrm{H}$ NMR spektrumainak részlete az alifás hidrogének tartományában $\left(c_{\mathrm{EC}}=1,1 \times 10^{-3} \mathrm{M}, \mathrm{H}_{2} \mathrm{O} / \mathrm{D}_{2} \mathrm{O}=90 / 10 \% \mathrm{v} / \mathrm{v}, I=0,1 \mathrm{M} \mathrm{NaClO}_{4}, T=298 \mathrm{~K}\right)$

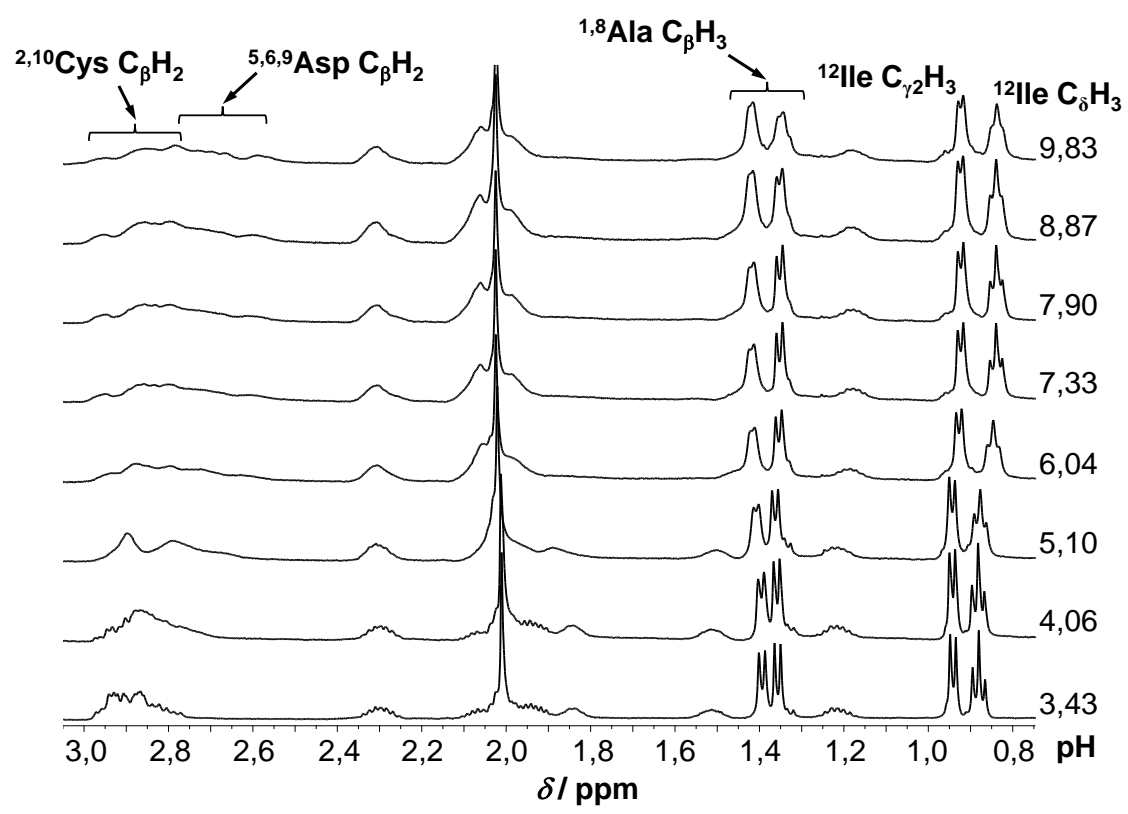


F37. ábra: $\mathrm{A} \mathrm{Cd}^{2+}$-EC 1:1 fémion:ligandum arányú rendszer pH-függő ${ }^{1} \mathrm{H} \mathrm{NMR}$ spektrumainak részlete az alifás hidrogének tartományában $\left(c_{\mathbf{E C}}=1,1 \times 10^{-3} \mathrm{M}, \mathrm{H}_{2} \mathrm{O} / \mathrm{D}_{2} \mathrm{O}=90 / 10 \% \mathrm{v} / \mathrm{v}, I=0,1 \mathrm{M} \mathrm{NaClO}_{4}, T=298 \mathrm{~K}\right)$

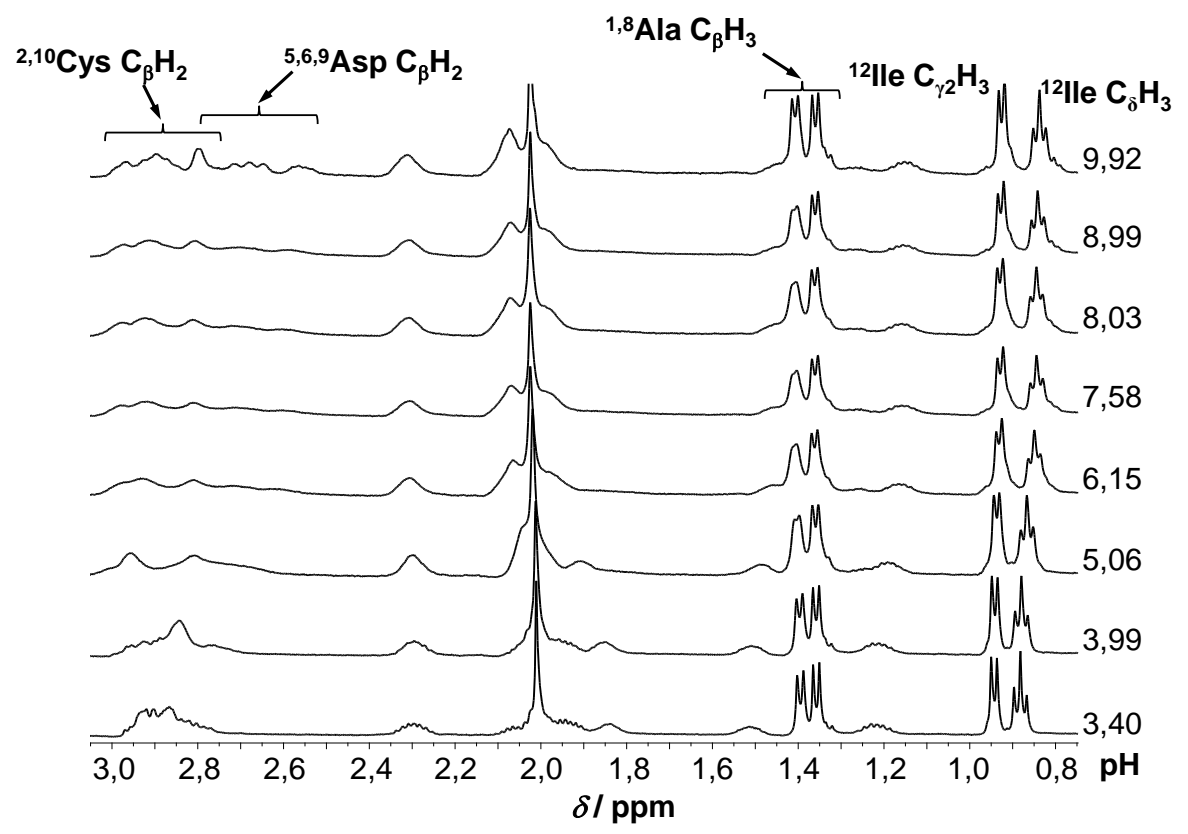

F38. ábra: $\mathrm{A} \mathrm{Zn}^{2+}$-EC 0,5:1 fémion:ligandum arányú rendszer $\mathrm{pH}$-függő ${ }^{1} \mathrm{H} \mathrm{NMR}$ spektrumainak részlete az alifás hidrogének tartományában $\left(c_{\mathbf{E C}}=1,12 \times 10^{-3} \mathrm{M}, \mathrm{H}_{2} \mathrm{O} / \mathrm{D}_{2} \mathrm{O}=90 / 10 \% \mathrm{v} / \mathrm{v}, I=0,1 \mathrm{M} \mathrm{NaClO}_{4}, T=298 \mathrm{~K}\right)$

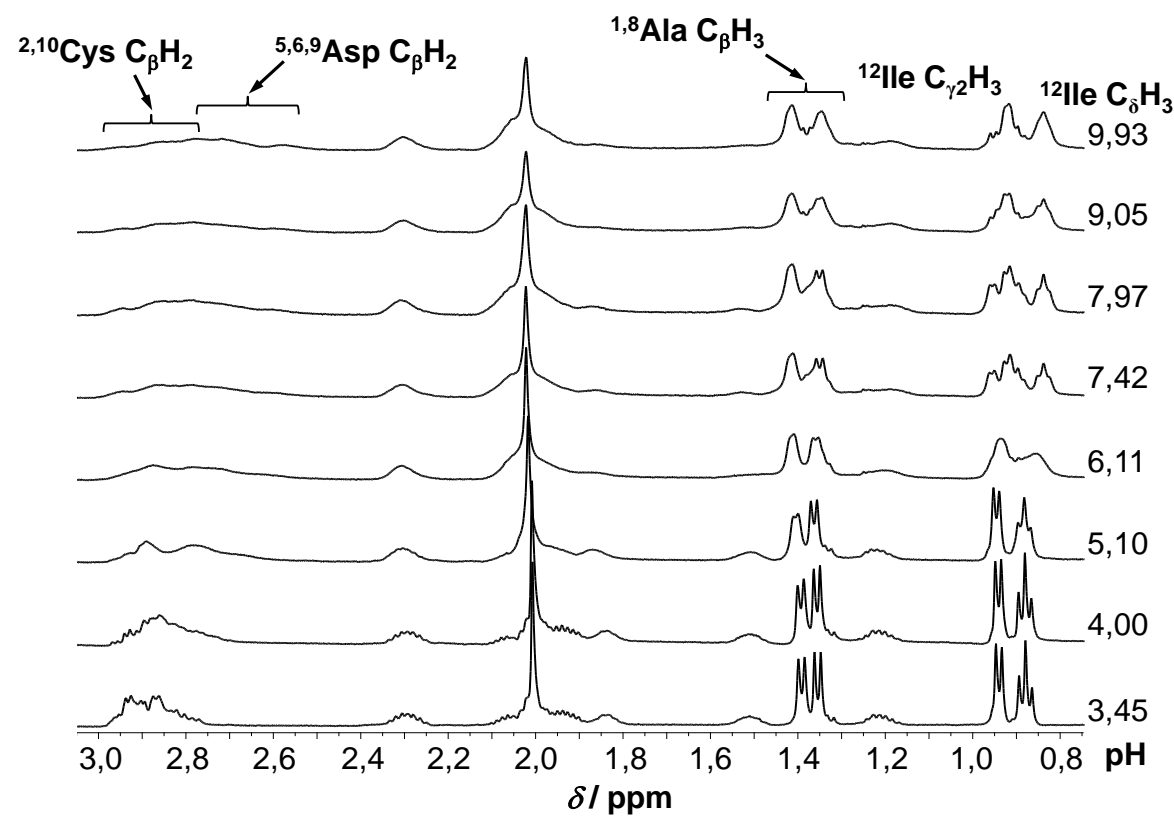


F39. ábra: $\mathrm{A} \mathrm{Cd}^{2+}$-EC 0,5:1 fémion:ligandum arányú rendszer $\mathrm{pH}$-függő ${ }^{1} \mathrm{H}$ NMR spektrumainak részlete az alifás hidrogének tartományában $\left(c_{\mathbf{E C}}=1,1 \times 10^{-3} \mathrm{M}, \mathrm{H}_{2} \mathrm{O} / \mathrm{D}_{2} \mathrm{O}=90 / 10 \% \mathrm{v} / \mathrm{v}, I=0,1 \mathrm{M} \mathrm{NaClO}_{4}, T=298 \mathrm{~K}\right)$

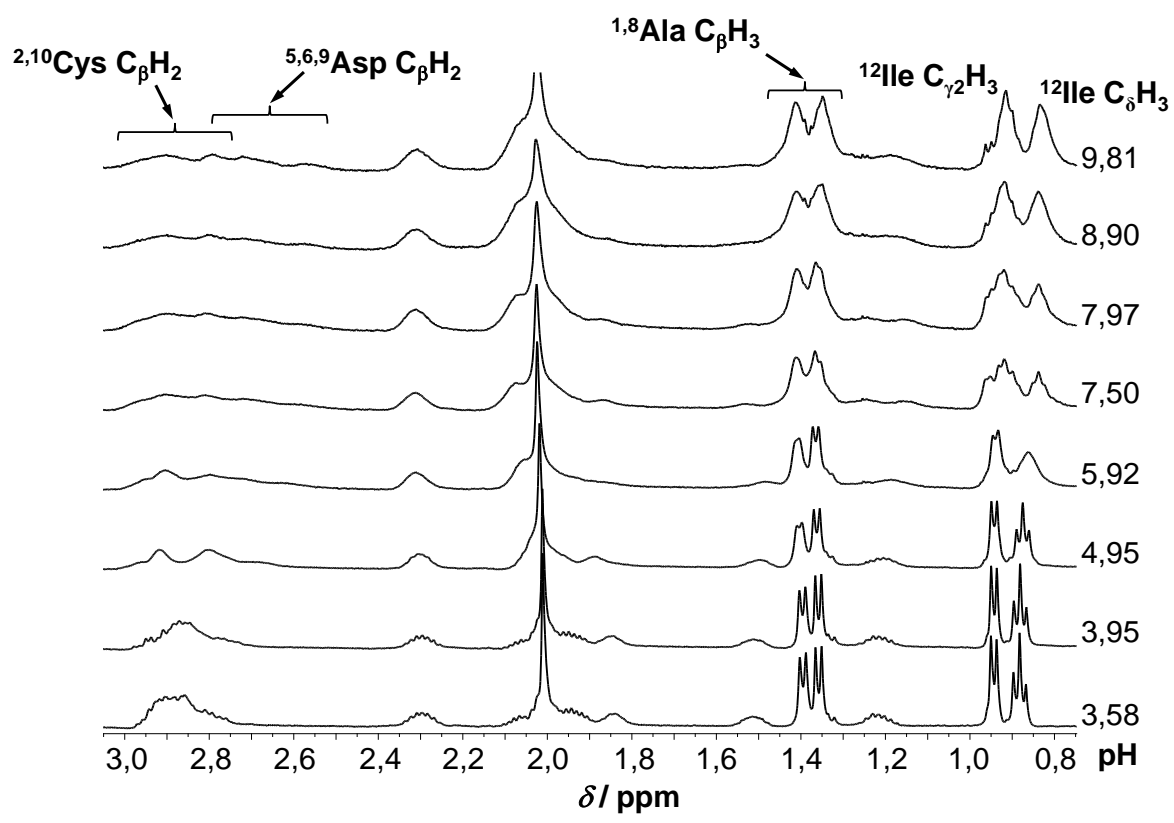


F40. ábra: $\mathrm{Hg}^{2+}$-PS $1: 1$ (bal) és a $\mathrm{Hg}^{2+}$-PS $0,5: 1$ (jobb) fémion:ligandum arányú rendszerek pH-függő UV spektrumai $\left(c_{\mathbf{P S}}=1,0 \times 10^{-4} \mathrm{M}, I=0,1 \mathrm{M} \mathrm{NaClO}_{4}, l=10 \mathrm{~mm}, T=298 \mathrm{~K}\right)$
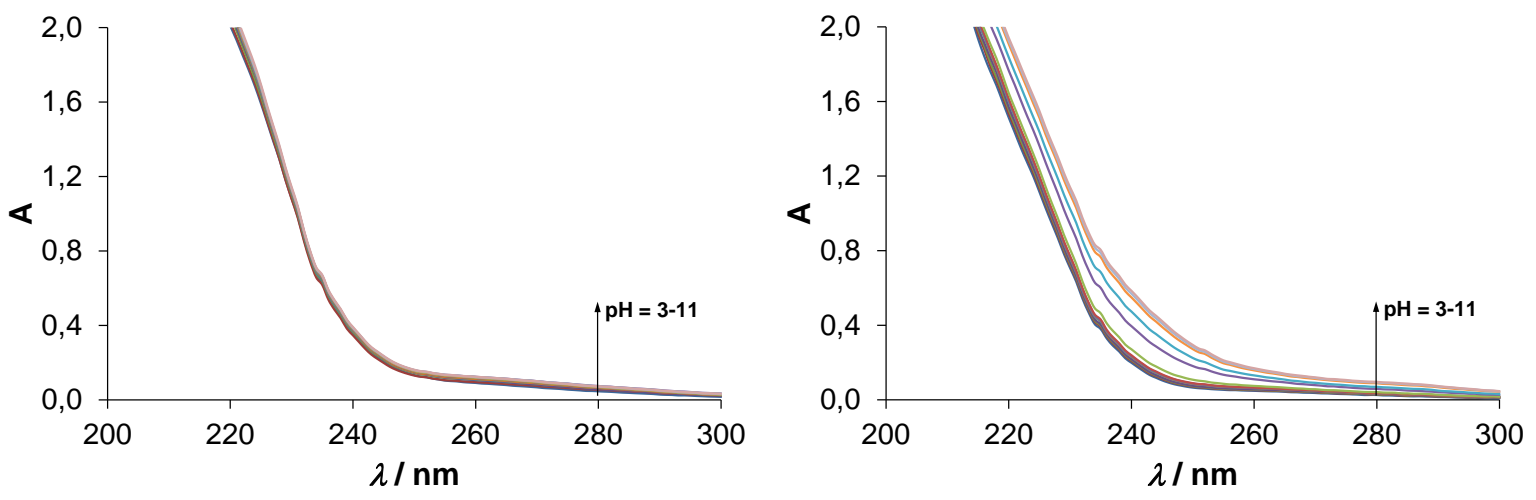

F41 ábra: $\mathrm{Hg}^{2+}$-EC 1:1 (bal) és a $\mathrm{Hg}^{2+}$-EC 0,5:1 (jobb) fémion: ligandum arányú rendszerek pH függő UV spektrumai $\left(c_{\mathbf{E C}}=1,0 \times 10^{-4} \mathrm{M}, I=0,1 \mathrm{M} \mathrm{NaClO}_{4}, l=10 \mathrm{~mm}, T=298 \mathrm{~K}\right)$
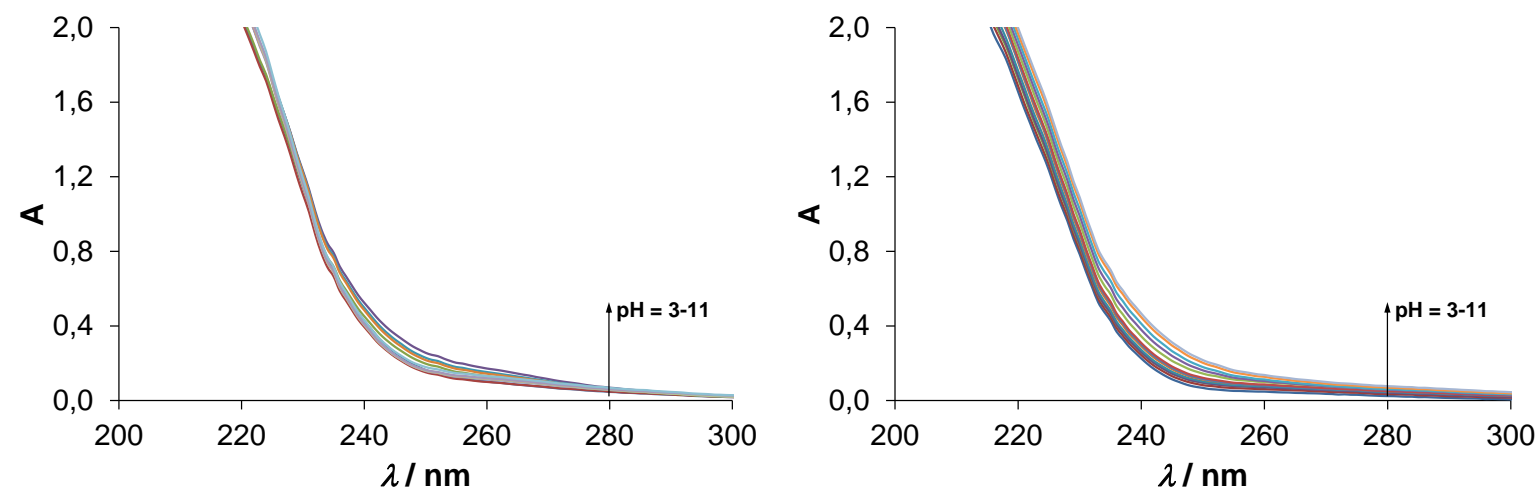

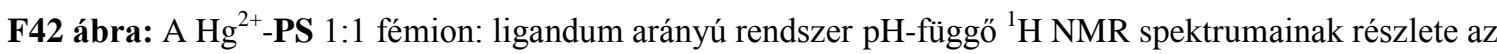
alifás hidrogének tartományában $\left(c_{\mathbf{P S}}=1,3 \times 10^{-3} \mathrm{M}, \mathrm{H}_{2} \mathrm{O} / \mathrm{D}_{2} \mathrm{O}=90 / 10 \% \mathrm{v} / \mathrm{v}, I=0,1 \mathrm{M} \mathrm{NaClO}_{4}, T=298 \mathrm{~K}\right)$

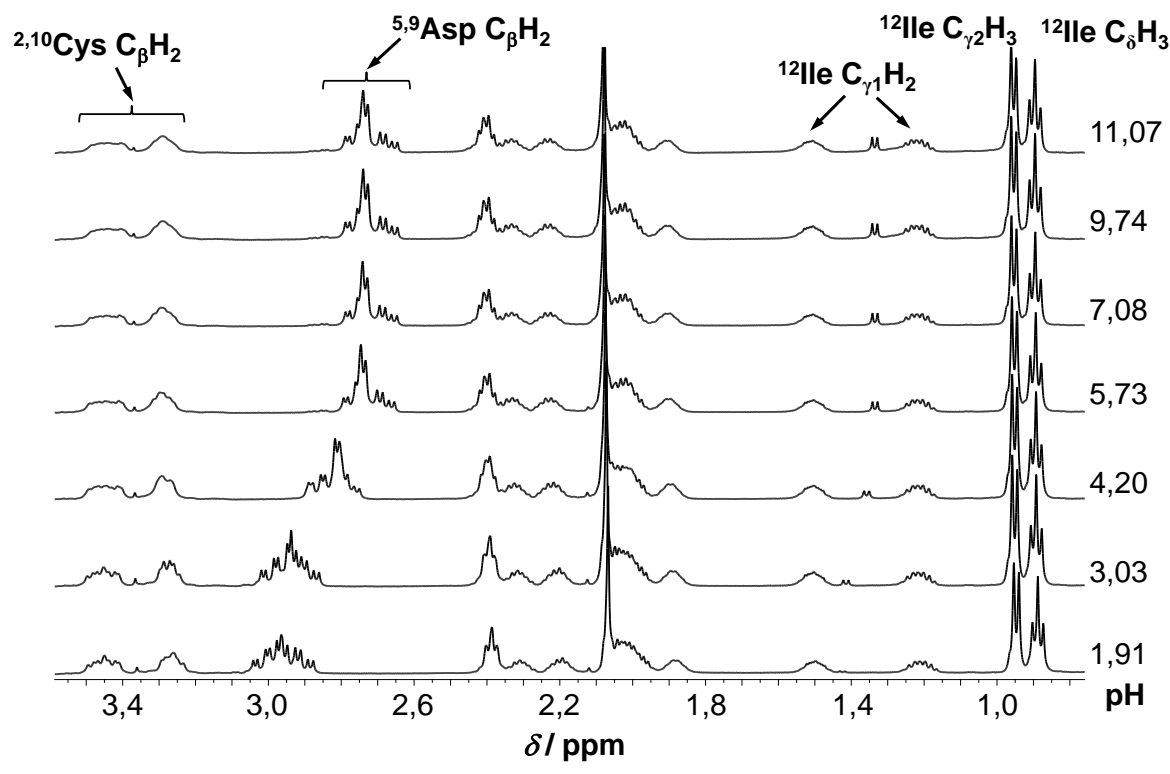


F43 ábra: $\mathrm{A} \mathrm{Hg}^{2+}$-PS 0,5:1 fémion: ligandum arányú rendszer pH-függő ${ }^{1} \mathrm{H}$ NMR spektrumainak részlete az alifás hidrogének tartományában $\left(c_{\mathbf{P S}}=1,3 \times 10^{-3} \mathrm{M}, \mathrm{H}_{2} \mathrm{O} / \mathrm{D}_{2} \mathrm{O}=90 / 10 \% \mathrm{v} / \mathrm{v}, I=0,1 \mathrm{M} \mathrm{NaClO}_{4}, T=298 \mathrm{~K}\right)$

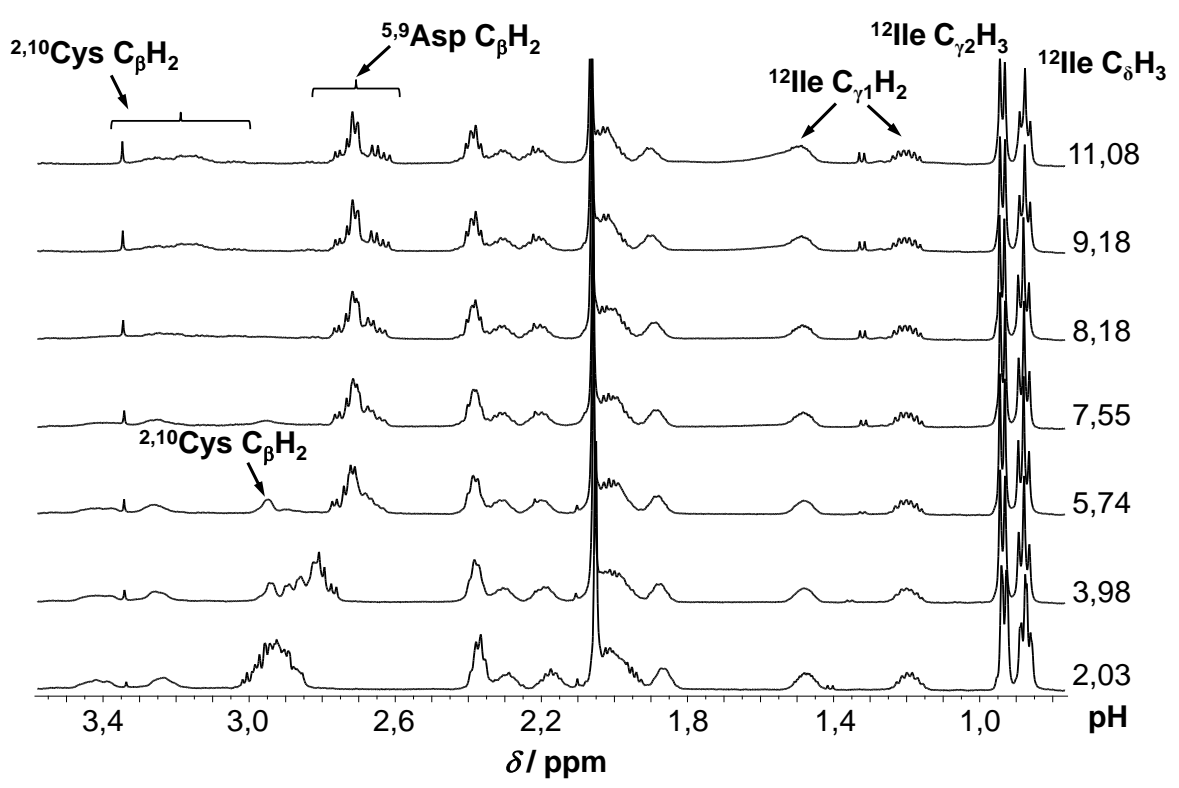

F44 ábra: $\mathrm{A} \mathrm{Hg}^{2+}$-EC 1:1 fémion: ligandum arányú rendszer pH-függő ${ }^{1} \mathrm{H}$ NMR spektrumainak részlete az alifás hidrogének tartományában $\left(c_{\mathrm{EC}}=1,1 \times 10^{-3} \mathrm{M}, \mathrm{H}_{2} \mathrm{O} / \mathrm{D}_{2} \mathrm{O}=90 / 10 \% \mathrm{v} / \mathrm{v}, I=0,1 \mathrm{M} \mathrm{NaClO}_{4}, T=298 \mathrm{~K}\right)$

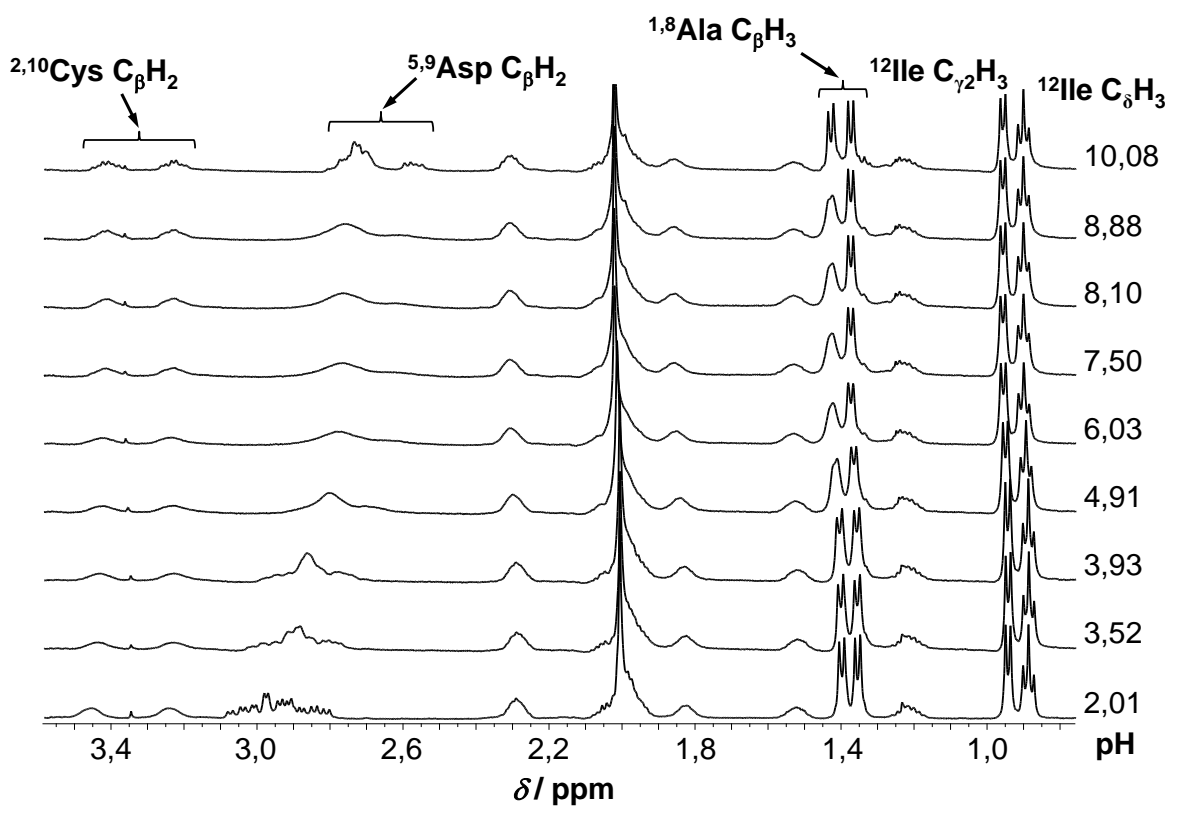


F45. ábra: Moláris UV spektrumok a $\mathrm{Hg}^{2+}-\mathrm{I}^{-}$rendszerben

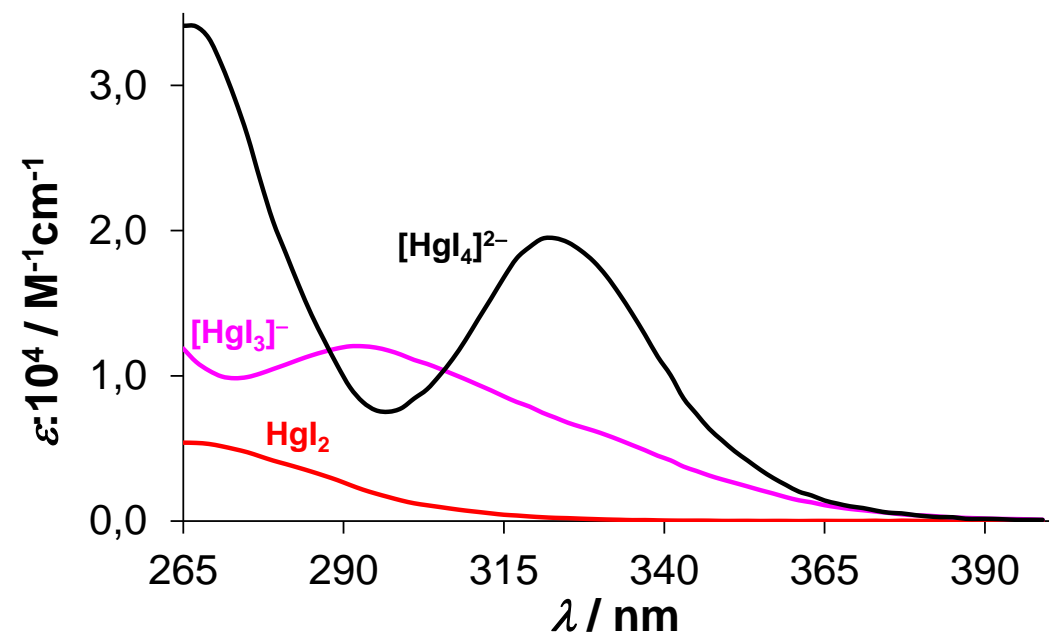

